UNIVERSIDADE DE BRASÍLIA - UnB

FACULDADE DE EDUCAÇÃO - FE

PROGRAMA DE PÓS - GRADUAÇÃO EM EDUCAÇÃO -PPGE

\title{
A AUTOAVALIAÇÃO NA UNIVERSIDADE DE BRASÍLIA: ENTRE A PROPOSTA DO SINAES E OS SINAIS DA PRÁTICA
}

\section{LUKELLY FERNANDA AMARAL GONÇALVES}

BRASÍLIA/DF

JUNHO DE 2016 


\title{
A AUTOAVALIAÇÃO NA UNIVERSIDADE DE BRASÍLIA: ENTRE A PROPOSTA DO SINAES E OS SINAIS DA PRÁTICA
}

\begin{abstract}
Dissertação apresentada ao Programa de PósGraduação em Educação da Universidade de Brasília, vinculada à Linha de Pesquisa Políticas Públicas e Gestão da Educação, como requisito parcial para a obtenção do título de Mestre em Educação, sob a orientação do Professor Dr. José Vieira de Sousa.
\end{abstract}

BRASÍLIA/DF

JUNHO DE 2016 


\section{LUKELLY FERNANDA AMARAL GONÇALVES}

\section{A AUTOAVALIAÇÃO NA UNIVERSIDADE DE BRASÍLIA: ENTRE A PROPOSTA DO SINAES E OS SINAIS DA PRÁTICA}

Dissertação apresentada ao Programa de PósGraduação em Educação da Universidade de Brasília, vinculada à Linha de Pesquisa Políticas Públicas e Gestão da Educação, como requisito parcial para a obtenção do título de Mestre em Educação, sob a orientação do Professor Dr. José Vieira de Sousa.

Brasília, 22 de junho de 2016.

\section{COMISSÃO EXAMINADORA}

Professor Dr. José Vieira de Sousa

(Orientador - Faculdade de Educação/Universidade de Brasília)

Professora Dra. Stela Maria Meneghel

(Examinadora externa - Fundação Universidade Regional de Blumenau/FURB)

Professora Dra. Marília Fonseca

(Examinadora interna - Faculdade de Educação/Universidade de Brasília)

Professora Dra. Maria Abádia da Silva

(Membro suplente - Faculdade de Educação/Universidade de Brasília) 
Dedico este estudo àquelas que são as mulheres mais importantes da minha vida:

À minha mãe, Fátima, por ser a maior responsável pela conclusão desta dissertação. Por trás de uma filha pesquisadora há sempre uma grande mãe psicóloga, motorista, nutricionista e até enfermeira.

À minha vovó Francisca por ser, ainda que sem saber, a grande inspiração minha e de toda a família. Professora aposentada da rede estadual de Minas Gerais, ela continua dando lições, mas de vida. 


\section{AGRADECIMENTOS}

E aprendi que se depende sempre de tanta muita diferente gente. Toda pessoa sempre é as marcas das lições diárias de outras tantas pessoas. (Gonzaguinha).

Agradeço, primeiramente, a Deus pelo lindo script que vem escrevendo para a minha vida. Tanto as cruzes como as alegrias me foram dadas no momento e intensidade certos, não tendo sido diferente no período do mestrado.

Agradeço, em segundo lugar, à minha família, base de tudo. Aos meus pais, Petrônio e Fátima, por serem meus exemplos diários de perseverança e por me motivarem constantemente a estudar e a realizar meus sonhos. E a meu irmão, Rodrigo, por ser meu equilíbrio entre a vida acadêmica e a rotina, já que sempre tratava de me lembrar que sou jovem ainda e que a diversão deve caminhar ao lado do estudo.

Ao meu orientador, professor Dr. José Vieira de Sousa, pela confiança depositada em mim, pelos feedbacks cuidadosos, por me inserir em grupos de pesquisa e por me ensinar, na prática, o significado da frase de Clarice Lispector estampada em um quadro de sua sala. Realmente, não é fácil escrever; é duro como quebrar rochas, mas voam faíscas e lascas como aço espelhado.

Às professoras Dras. Marília Fonseca e Stela Maria Meneghel por aceitarem o convite de fazerem parte da minha banca e pelos direcionamentos me dados no momento da qualificação. As ponderações contribuíram muito para o aprimoramento deste trabalho.

Aos grupos de estudo dos quais faço parte - Sub 3 do Universitas/Br (POW1) e Grupo de Políticas de Avaliação da Educação Superior (Gepaes) -, por terem me ajudado a expandir meus conhecimentos metodológicos e conteudistas.

Aos entrevistados, do Inep, Conaes, UnB, Unifesp, USP, UFSCar e UFMG, pela "aula" me proporcionada em seus minutos de entrevista e também pela disponibilidade para tal. E aos da UnB, em especial, por, com suas posturas como membros da Comissão Própria de Avaliação, terem me mostrado o que é trabalhar por uma causa mesmo diante de adversidades.

À professora Dra. Maria Abádia da Silva por desde o momento da prova oral de seleção do mestrado até a conclusão deste trabalho ter sido a pessoa que na UnB me acalma e me devolve a serenidade que às vezes o ambiente acadêmico me tira. 
Às amigas Cris, Dani, Gabi, Grazi, Lari, Rê, Rebeca e Tuty por terem me dado suporte na escrita desta pesquisa em momento pontual ou durante todo o período do mestrado. As formatações, as traduções, as leituras "despropositadas", bem como os conselhos, os consolos e os convites para saídas planejadas com bastante antecedência foram muito importantes.

Às amigas/colegas do Programa de Pós Graduação em Educação da Universidade de Brasília, Arlete, Desirée, Juliana, Luciana, Paola e Regina, por terem sido - em algum dia ou em vários - minhas confidentes de angústias e conquistas que só quem está cursando ou já cursou um mestrado ou doutorado entende.

Às amigas Amada, de Natal, Ivy, de São Paulo, e Tereza, de Guadalajara, por me hospedarem em suas casas quando por coincidência ou destino visitei suas cidades em virtude de algum congresso ou simpósio.

À amiga Taís (in memorian) por ser meu anjinho da guarda desde o segundo semestre do mestrado e por ter me ensinado, já há muito, que "o mundo é nosso" e que a vida é curta e não só acadêmica.

À tia Eliane e à amiga Tainá e suas respectivas famílias por terem feito de suas casas um pouso seguro e certo para comidas rápidas entre uma aula e outra ou mesmo para passar a noite até a aula de 8 da manhã.

Aos meus tios, primos e amigos que compreenderam a minha ausência em momentos importantes, como nascimento de filho, e que torceram pelo meu sucesso. E à "Baixinha" que às vezes era quem encontrava aquele papel importante que se perdia em meio a tantos outros.

À Universidade de Brasília, na figura dos professores da Faculdade de Educação, pela preocupação em dialogar o conteúdo das matérias com os objetos de pesquisa sempre tão diversos de seus alunos.

À Universidade Federal de Ouro Preto (mãe UFOP), na figura dos professores e colegas do Instituto de Ciências Humanas e Sociais (ICHS), por ter me iniciado na pesquisa em educação e me ensinado que a concretização de certos sonhos depende da dedicação do estudante, mas também de uma graduação de qualidade. Meu primeiro olhar sobre a avaliação da educação como objeto de estudo se deu na UFOP e, hoje, na UnB, colho os primeiros frutos desse direcionamento.

A todos os citados e implícitos, muito obrigada. 
Todo começo é difícil - isso vale para qualquer ciência.

Karl Marx 


\section{RESUMO}

Esta dissertação trata da autoavaliação - componente do Sistema Nacional de Avaliação da Educação Superior (Sinaes) - na Universidade de Brasília (UnB), já que essa foi precursora da avaliação institucional no país, no âmbito da educação superior. O estudo teve como objetivo compreender em que medida o previsto pelo Sinaes para a autoavaliação é ressignificado; e se justifica pela relevância dessa discussão no contexto de uma política avaliativa formativa que tem como foco as instituições de educação superior (IES). Por meio da abordagem qualitativa e do estudo de caso, se analisou a construção do significado da autoavaliação pela comunidade acadêmica da instituição; a conformação do processo autoavaliativo às dimensões estabelecidas pelo Sinaes; e a utilidade dos resultados, tendo como recorte temporal os anos de 2014 e 2015, os quais já carregam reformulações na autoavaliação adotadas a partir do primeiro ano em questão. A coleta de dados foi realizada recorrendo a documentos oficiais e entrevistas semiestruturadas realizadas com atores que lidam com a autoavaliação das IES tanto do ponto de vista teórico como da prática - um representante da Comissão Nacional de Avaliação da Educação Superior, um da Diretoria de Avaliação da Educação Superior do Instituto Nacional de Estudos e Pesquisas Educacionais Anísio Teixeira, quatro pesquisadores brasileiros da área de avaliação da educação superior e quatro membros da Comissão Própria de Avaliação (CPA) da UnB, neste último caso cada um deles pertencente a um segmento representativo da Comissão - docente, discente, técnico administrativo e sociedade civil organizada. Para analisar os documentos e falas, recorreu-se à análise documental sob a perspectiva de Bardin (2004) e adotou-se um olhar dialético que conduziu todo o processo da pesquisa. Com o auxílio das categorias metodológicas mediação e contradição, assim como das de conteúdo: regulação, avaliação formativa, qualidade da educação superior e relatórios de autoavaliação reduzidos ao cumprimento burocrático, esse olhar permitiu contemplar os objetivos da pesquisa, sempre levando em consideração os embates e tensões inerentes à implementação de uma avaliação. A dissertação confirma a tese de que a autoavaliação ainda precisa avançar, já que devido às marcas da subsunção do passado e do presente, não logra exercer seu papel formativo intencional. Tomando a UnB como referência, percebeu-se que nem os anos de experiência avaliativa desta foram capazes de driblar a situação de preterimento ao qual a autoavaliação encontra-se. Em todas as fases previstas para esse processo avaliativo - preparação, desenvolvimento e consolidação -, percebe-se uma instituição que ainda precisa compreender o que é a autoavaliação e qual a importância dela, dos agentes que a coordenam e do uso dos resultados. Os membros da CPA investigada, mesmo diante de uma sobrecarga de trabalho, esforçam-se para tornarem a autoavaliação formativa. Ações de sensibilização da comunidade e de revisão dos instrumentos aplicados no processo têm sido importantes para o andamento da avaliação e para, a médio ou longo prazo, se ter uma comunidade acadêmica que se envolva no processo e se reconheça nele. O relatório de autoavaliação evidencia uma Comissão que-ainda não se impõe como real coordenadora do processo. Com muitas descrições e poucas evidências que suscitem deliberações, o relatório apresenta resultados que servem mais ao cumprimento burocrático de postagem no sistema e-MEC do que a mudanças por parte da gestão. Percebese, contudo, que isso se deve não somente a forma como a UnB vem conduzindo a autoavaliação, mas, sobretudo, a um contexto de omissão e subsunção no qual essa avaliação historicamente encontra-se inserida nos últimos anos.

Palavras-chave: Avaliação da educação superior. Sinaes. Autoavaliação. Uso dos resultados. Universidade de Brasília. 


\section{ABSTRACT}

This dissertation refers to the self-assessment - component of the National System for Evaluation of the Higher Education (Sinaes) at the University of Brasilia (UnB), since this was the precursory institutional assessment in the country, in the context of higher education. The study had as objective to comprehend in which way what has been foreseen by the Sinaes for self-assessment receives a new significance; and it justifies itself by the importance of this discussion in the context of an assessment policy that focuses on higher education institutions (IES). By means of a qualitative approach and the case study, it was possible to analyze the construction of the meaning of self-assessment by the academic community of the institution; the conformation of the self-assessment process to the dimensions established by the Sinaes; and the utility of the results, having as a time frame the years of 2014 and 2015, which already suffered reformulations in self-assessment adopted from the first year. The data gathering was carried out by consulting official documents and through semi-structured interviews with actors that are involved in the selfassessment field of the higher education institutions from both theoretical and practical point of view - one representative of the National Commission for Evaluation of the Higher Education (Conaes), one from the Directorate of Higher Education Assessment of the National Institute of Educational Studies and Research Anísio Teixeira (Daes/Inep), four Brazilian researchers of the higher education assessment field and four members of the Sefl Evaluation Commission (CPA) of UnB, each one of these four members belonging to a representative segment of the Commission - professor, student, technical administrative and organized civil society. In order to analyze the documents and speeches, a documentary analysis was performed under the perspective of Bardin (2004) and it was adopted a dialect view that conducted the entire research process. With the assistance of the mediation and contradiction methodological categories, as well as the ones of content: regulation, formative assessment, quality of the higher education and self-assessment reports kept to the bureaucratic fulfillment, this view allowed to contemplate the objectives of the research, always taking into consideration the confrontations and tensions inherent to the implementation of assessment. The dissertation confirms the thesis that the selfassessment still needs to be developed, considering that, due to the stains of belonging to a set of norms in the past and in the present, it is not able to perform its intentional formative role. Having UnB as reference, it was possible to notice that even its years of experience in assessment were not able to avoid the neglecting situation in which the self-assessment was taken to. In all planned phases of this appraisal process - preparation, development and consolidation -, it is possible to notice an institution that still needs to comprehend what self-assessment is and its importance, the agents that coordinate it and the utility of the results. The members of the investigated CPA, even when facing a work overload, strive to become self-assessment formative. Actions to provoke community awareness and revising the tools that are applied in the process have been considered important to the progress of the assessment and to have an academic community that gets more involved in the process and recognizes itself in it. The self-assessment report demonstrates a Commission that does not impose itself as the real coordinator of the process. With many descriptions and little evidences that evoke deliberations, the report shows outcomes that are more suitable to the bureaucratic fulfillment of feeding on the e-MEC system than the changes by the management. It is possible to notice, however, that this is not only due to the manner by which UnB has been conducting the self-assessment, but, mainly, to a context of omission and subsumption, in which this assessment has been historically inserted, in recent years years.

Keywords: Evaluation of the Higher Education. Sinaes. Self-Assessment. Utility of the results. University of Brasilia. 


\section{LISTA DE ABREVIATURAS E SIGLAS}

Abruc Associação Brasileira de Universidades Comunitárias

$\mathrm{AC}$ Acre

ACG

Avaliação dos Cursos de Graduação

$\mathrm{ACO}$

Avaliação das Condições de Oferta

$\mathrm{AM}$

Amazônia

Andifes

Associação Nacional dos Dirigentes das Instituições Federais de Ensino Superior

AP

Amapá

Avalies

Avaliação das Instituições de Educação Superior

BDTD

Biblioteca Digital Brasileira de Teses e Dissertações

BID

Banco Interamericano de Desenvolvimento

$\mathrm{BM}$

Banco Mundial

CAI

Comissão de Avaliação Institucional

Capes

Coordenação de Aperfeiçoamento de Pessoal de Nível Superior

$\mathrm{CC}$

Conceito de Curso

CEA

Comissão Especial de Avaliação

CEBRAP

Centro Brasileiro de Análise e Planejamento

Cedes

Centro de Estudos Educação e Sociedade

Cefet

Centro Federal de Educação Tecnológica

CEPAL

Comisión Económica para América Latina y el Caribe

CEPE

Conselho de Ensino, Pesquisa e Extensão

$\mathrm{CF}$

Constituição Federal

CFE

Conselho Federal de Educação

CGCQES Coordenação Geral de Controle de Qualidade da Educação Superior

CIPP

Contexto-Insumos-Processos e Produtos

$\mathrm{CNE}$

Câmara Nacional de Educação

$\mathrm{CNPq}$

Conselho Nacional de Desenvolvimento Científico e Tecnológico

CNRE

Comissão Nacional para a Reforma da Educação Superior

Codeplan

Companhia de Planejamento do Distrito Federal

Conaes

Comissão Nacional de Avaliação da Educação Superior

CPA

Comissão Própria de Avaliação

$\mathrm{CPC}$

Conceito Preliminar de Curso

CTAA

Comissão Técnica de Acompanhamento da Avaliação 
Daes Diretoria de Avaliação da Educação Superior

DCE Diretrizes Curriculares Nacionais

DIEESE Departamento Intersindical de Estatística e Estudos Socioeconômicos

Enade Exame Nacional de Desempenho dos Estudantes

ENC Exame Nacional de Cursos

Enem Exame Nacional do Ensino Médio

ES Educação Superior

FACE Faculdade de Economia, Administração e Contabilidade

FE

Faculdade de Educação

Fepecs $\quad$ Fundação de Ensino e Pesquisa em Ciências da Saúde

FHC Fernando Henrique Cardoso

FMI Fundo Monetário Internacional

FIES Financiamento Estudantil

FUB Fundação Universidade de Brasília

FURB Universidade Regional de Blumenau

GDF Governo do Distrito Federal

Geres Grupo Executivo para a Reformulação do Ensino Superior

GTA Grupo Técnico de Avaliação

GUNI Global University Network for Innovation

IBGE Instituto Brasileiro de Geografia e Estatística

IBICT Instituto Brasileiro de Informações em Ciência e Tecnologia

ICHS Instituto de Ciências Humanas e Sociais

IDD Indicador de Diferença entre os Desempenhos Observado e Esperado

IES Instituição de Educação Superior

IESALC Instituto Internacional de Educación Superior para América Latina y el Caribe

IF Instituto Federal

IGC Índice Geral de Cursos

Inep Instituto Nacional de Estudos e Pesquisas Educacionais Anísio Teixeira

IUPERJ Instituto Universitário de Pesquisas do Rio de Janeiro

LDBEN Lei de Diretrizes e Bases da Educação Nacional

LNCC Laboratório Nacional de Computação Científica

MEC Ministério da Educação

OCDE Organização para a Cooperação e Desenvolvimento Econômico

OMC Organização Mundial do Comércio 


\begin{tabular}{|c|c|}
\hline ONU & Organização das Nações Unidas \\
\hline PA & Pará \\
\hline Paideia & $\begin{array}{l}\text { Processo de Avaliação Integrada do Desenvolvimento Educacional e da } \\
\text { Inovação da Área }\end{array}$ \\
\hline Paiub & Programa de Avaliação Institucional das Universidades Brasileiras \\
\hline Paru & Programa de Avaliação da Reforma Universitária \\
\hline PAS & Programa de Avaliação Seriada \\
\hline PDI & Plano de Desenvolvimento Institucional \\
\hline PNAD & Pesquisa Nacional por Amostra de Domicílios \\
\hline PNE & Plano Nacional de Educação \\
\hline Poge & Políticas Públicas e Gestão da Educação \\
\hline PPGE & Programa de Pós-Graduação em Educação \\
\hline PUC & Pontifícia Universidade Católica \\
\hline RA & Região Administrativa \\
\hline Reuni & $\begin{array}{l}\text { Programa de Apoio a Planos de Reestruturação e Expansão das } \\
\text { Universidades Federais }\end{array}$ \\
\hline RiUnB & Repositório Institucional da Universidade de Brasília \\
\hline RO & Rondônia \\
\hline $\mathrm{RR}$ & Roraima \\
\hline Seed & Secretaria de Educação a Distância \\
\hline SEEDF & Secretaria de Estado de Educação do Distrito Federal \\
\hline $\mathrm{SESu}$ & Secretaria de Educação Superior \\
\hline Setec & Secretaria de Educação Profissional e Tecnológica \\
\hline Sinaes & Sistema Nacional de Avaliação da Educação Superior \\
\hline Sinapes & Sistema Nacional e Progresso do Ensino Superior \\
\hline TCU & Tribunal de Contas da União \\
\hline TRI & Teoria de Resposta ao Item \\
\hline UCAM & Universidade Cândido Mendes \\
\hline UDF & Universidade do Distrito Federal \\
\hline UEM & Universidade Estadual de Maringá \\
\hline UFBA & Universidade Federal da Bahia \\
\hline UFC & Universidade Federal do Ceará \\
\hline UFG & Universidade Federal de Goiás \\
\hline UFJF & Universidade Federal de Juiz de Fora \\
\hline UFMG & Universidade Federal de Minas Gerais \\
\hline
\end{tabular}




$\begin{array}{ll}\text { UFMT } & \text { Universidade Federal do Mato Grosso } \\ \text { UFOP } & \text { Universidade Federal de Ouro Preto } \\ \text { UFPA } & \text { Universidade Federal do Pará } \\ \text { UFPe } & \text { Universidade Federal do Pernambuco } \\ \text { UFPR } & \text { Universidade Federal do Paraná } \\ \text { UFRGS } & \text { Universidade Federal do Rio Grande do Sul } \\ \text { UFRJ } & \text { Universidade Federal do Rio de Janeiro } \\ \text { UFSC } & \text { Universidade Federal de Santa Catarina } \\ \text { UFV } & \text { Universidade Federal de Viçosa } \\ \text { UnB } & \text { Universidade de Brasília } \\ \text { UNE } & \text { União Nacional dos Estudantes } \\ \text { Unesco } & \text { Organização das Nações Unidas para a Educação, a Ciência e a Cultura } \\ \text { Uniban } & \text { Universidade Bandeirante } \\ \text { Unicamp } & \text { Universidade de Campinas } \\ \text { Unifesp } & \text { Universidade Federal de São Paulo } \\ \text { Unisinos } & \text { Universidade do Vale do Rio dos Sinos } \\ \text { Uniso } & \text { Universidade de Sorocaba } \\ \text { UPF } & \text { Universidade de Passo Fundo } \\ \text { USP } & \text { Universidade de São Paulo }\end{array}$




\section{ILUSTRAÇÕES}

Ilustração 1 - Mapa da localização geográfica dos campi da universidade selecionada para a pesquisa

Ilustração 2 - Triangulação de dados da pesquisa …………………………….......

Ilustração 3 - Enfoques da evolução das políticas de avaliação da educação superior brasileira e as diferentes concepções avaliativas ............. 118

Ilustração 4 - Três momentos/fases que compõem a autoavaliação no Sinaes.....

Ilustração 5 - Ações realizadas pelos grupos representativos da pesquisa em 2014 e 2015 e projetadas para os mesmos em prol do alcance da cultura de avaliação formativa e de autoavaliação.

\section{LISTA DE QUADROS}

Quadro 1 - Códigos e perfis dos sujeitos da pesquisa

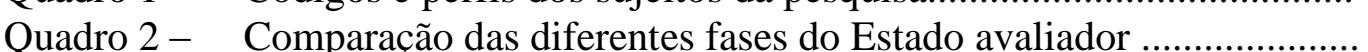

Quadro 3 - Visões de qualidade em educação superior .........................................

Quadro 4- Esquema das propostas de avaliação da educação superior brasileira nas décadas de 1980 e 1990

Quadro 5 - Dimensões para a autoavaliação e avaliação externa............................

Quadro 6 - Políticas para educação superior orientadas pelo Enade, CPC e IGC.

Quadro 7 - Dimensões, indicadores e pesos referentes à avaliação institucional externa.

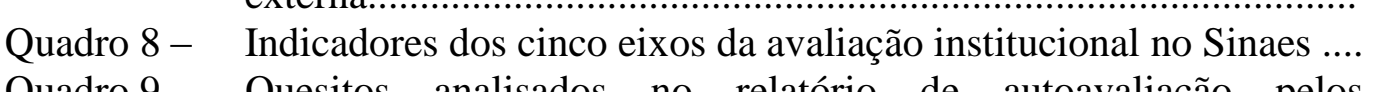

Quadro 9- Quesitos analisados no relatório de autoavaliação pelos avaliadores institucionais externos.

Quadro 10- Síntese das problemáticas identificadas na prática da autoavaliação da UnB relativas aos anos de 2014 e 2015 .

\section{LISTA DE TABELAS}

Tabela 1 - Evolução das taxas de escolarização bruta e líquida na educação superior - Brasil e regiões (2001-2011)

Tabela 2 - Evolução do número de IES no Brasil - 1980 a 2014 ...........................

Tabela 3 - Pesos estabelecidos em 2015 para as dimensões que corroboram os processos de autorização, reconhecimento e renovação de reconhecimento no Sinaes

Tabela 4 - Frequência das categorias identificadas nas atas de janeiro de 2011 a novembro a novembro de 2015 das reuniões ordinárias da Conaes. 


\section{SUMÁRIO}

CONSIDERAÇÕES INICIAIS

1 AVALIAÇÃO DA EDUCAÇÃO SUPERIOR E O DESAFIO DE FOMENTAR A QUALIDADE: CONCEPÇÕES DIVERGENTES EM DEBATE

1.1 Introdução

1.2 Instituições de educação superior priorizadas em tempos de expansão: as diversas finalidades educacionais

1.3 Dificuldades na implementação de uma avaliação formativa............................. 73

1.4 Qualidade da educação superior: tensões à vista..................................... 86

$1.5 \quad$ Síntese parcial ................................................................................ 96

2 POLÍTICAS DE AVALIAÇÃo DA EDUCAÇÃo SUPERIOR BRASILEIRA: AS IDAS E VINDAS DAS AVALIAÇÕES FORMATIVA E CONTROLADORA................................................... 100

$2.1 \quad$ Introdução ......................................................................................... 100

2.2 Antecedentes históricos da avaliação da educação superior brasileira...... 102

2.3 Concepção e implementação do Sistema Nacional de Avaliação da Educação Superior - os empasses e contradições do processo................... 119

2.3.1 Concepção do Sinaes............................................................................ 120

2.3.2 Implementação do Sinaes: mudanças e entraves.......................................... 133

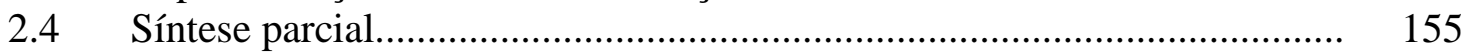

3 AUTOAVALIAÇÃO NA UNIVERSIDADE DE BRASÍLIA: ENTRAVES E POSSÍVEIS AVANÇOS................................................. 157

Introdução ........................................................................................ 157

3.1 Perspectivas de análise e interpretação dos dados....................................... 160

3.2 Autoavaliação desconhecida: as dificuldades de se preparar uma CPA e uma comunidade acadêmica para esse processo avaliativo.......................... 163

3.4 Processo autoavaliativo e seus resultados: o embate entre as funções formativa e burocrática dos relatórios.......................................................... 183

3.5 Síntese parcial..................................................................................... 201

CONSIDERAÇÕES FINAIS..................................................................... 206

REFERÊNCIAS................................................................................ 216

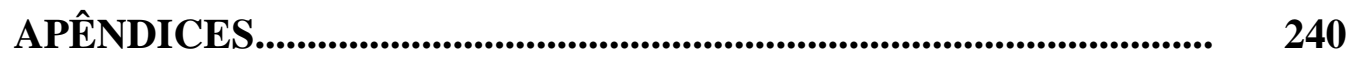




\section{CONSIDERAÇÕES INICIAIS}

A presente dissertação, intitulada A autoavaliação na Universidade de Brasília ${ }^{1}$ : entre a proposta do Sinaes e os sinais da prática, foi desenvolvida no âmbito do mestrado do Programa de Pós-Graduação em Educação (PPGE) da Universidade de Brasília (UnB). Tratase de um estudo vinculado à Linha de Pesquisa Políticas Públicas e Gestão da Educação (Poge) e ao Eixo de Interesse "Avaliação Institucional e suas Implicações na Gestão da Educação Superior", inscrevendo-se no campo das políticas públicas de avaliação da educação superior.

Objeto, recorte temporal, problema e tese da pesquisa - A pesquisa em questão tem como objeto o processo de autoavaliação institucional desenvolvido sob o escopo do Sistema Nacional de Avaliação da Educação Superior (Sinaes) (BRASIL, 2004a); e tomou como base as experiências de uma universidade precursora da autoavaliação no país: a Universidade de Brasília $^{2}$.

A educação superior ${ }^{3}$ no Brasil, seguindo uma tendência mundial, conta, sobretudo a partir da década de 1980, com consideráveis debates relacionados às políticas definidas para o setor. De modo geral, essas políticas tentam dar homogeneização e coerência ao sistema educacional brasileiro e se valem, para tal, principalmente, de avaliações. (MOROSINI; FRANCO, 2002).

Desde 2004, no país, conta-se com o Sinaes, sistema avaliativo que instaura a obrigatoriedade da prática da autoavaliação e que vem mostrando-se estável. Contudo, antes

\footnotetext{
${ }^{1}$ O Distrito Federal localiza-se no centro do Estado de Goiás e é um território autônomo, sendo, por conseguinte, sede dos poderes Executivo, Legislativo e Judiciário. De acordo com o Instituto Brasileiro de Geografia e Estatística, em 2015 o mesmo contava com uma população estimada de 2.914.830 e ocupava uma área de $5.779,999 \mathrm{~km}^{2}$ (IBGE, 2016). Essa área, por sua vez, encontrava-se dividida, no ano em questão, em 31 Regiões Administrativas (RA), sendo Brasília uma delas. Essa última foi: planejada por Lúcio Costa; construída em, aproximadamente, quarenta e um meses, durante o governo do presidente Juscelino Kubitschek de Oliveira (1956-1961); inaugurada em 21 de abril de 1960; é a sede do Governo do Distrito Federal (GDF); e compreende, em termos urbanos, a Asa Norte, a Asa Sul e a área central, que inclui a Esplanada dos Ministérios. (SOUSA, 2013).

${ }^{2}$ A Universidade de Brasília sobressa-se no país como precursora da avaliação institucional, com destaque para a autoavaliação, tendo servido de base, inclusive, à criação do Sistema Nacional de Avaliação da Educação Superior. (BRASIL/Inep/Conaes, 2004a).

${ }^{3}$ Com a promulgação em 1996 da Lei de Diretrizes e Bases da Educação Nacional - Lei no 9.394/1996 -, a organização da educação escolar passou a ser dividida em dois níveis: (i) "educação básica", composta por educação infantil, ensino fundamental e ensino médio; e (ii) "educação superior", composta por pós-graduação, graduação, cursos sequenciais e extensão. (BRASIL, 1996). Em respeito à mudança, se manterá a nomenclatura "ensino superior" - termo que estava válido até antes da promulgação da Lei - somente em citações de autores que a utilizem ou quando se estiver discorrendo sobre situações específicas anteriores ao ano de 1996. Nos casos referentes ao período pós-LDB utilizar-se-á a expressão “educação superior”.
} 
desse, houve um longo processo histórico que determinou tanto a instauração de outros projetos de avaliações e avaliações propriamente ditas, como a funcionalidade dessas. E essa historicidade não pode ser ignorada, pois influencia o Sinaes, tanto em sua concepção como em sua prática, sendo, portanto, necessária à compreensão do objeto desta pesquisa - a autoavaliação.

Desse modo, tem-se como recorte temporal do estudo os anos de 2014 e 2015, que compreendem a gestão do Professor Doutor Ivan Marques de Toledo Camargo como reitor da UnB, visto que o primeiro ano em questão caracterizou um período de contínuas ações sobre a autoavaliação no país. Foram elas: a instituição do documento "Instrumento de avaliação institucional externa" (BRASIL/Inep/Daes, 2014), da Portaria ${ }^{\circ}$ 92, de 31 de janeiro de 2014 (BRAIL/MEC, 2014) e da Nota Técnica do Inep/Daes/Conaes nº65, de 09 de outubro de 2014 (BRASIL/Inep/Conaes, 2014), discutidas no capítulo dois. Todavia, o resgate histórico do contexto que envolve o objeto foi utilizado como condição sine qua non à compreensão da autoavaliação na Universidade de Brasília.

Sendo assim, tem-se que até meados da década de 1970, especialmente as grandes potências mundiais viviam sob a égide de um Estado de bem estar social - Welfare State -, assim chamado especialmente por ter como foco a manutenção de direitos de cunho social, a exemplo da educação ${ }^{4}$. Porém, essa configuração estatal passou a apresentar sinais de esgotamento e inviabilidade quando da crise mundial instaurada à época em questão. Em tempos de baixo crescimento econômico, a solução para a restauração do lucro e do processo de acumulação capitalista foi ocultar o modelo de compromisso social do Estado de bem estar social, cedendo lugar ao neoliberalismo. ${ }^{5}$ (RIBEIRO, 2012). Nessa nova configuração estatal defendia-se ser preciso flexibilizar a participação do Estado e criar mecanismos para que o próprio mercado consumidor regulasse, por exemplo, a educação. (BARREYRO; ROTHEN, 2007). Os países, no entanto, aos quais não seria interessante curvar-se totalmente a mercados

\footnotetext{
4 O Estado de bem estar social surgiu no século XX e conta com várias teorias sobre seu desenvolvimento e implementação. Conforme Nogueira (2001), no entanto, há um consenso de que esse "se constitui como um elemento estrutural ao capitalismo contemporâneo, sendo que significou mais do que um incremento nas políticas sociais. Representou um esforço de reconstrução econômica, moral e política do mundo industrial desenvolvido e um anteparo à possível ampliação de propostas comunistas." (p. 99).

${ }^{5}$ Conforme Teixeira (1996), o "neoliberalismo nasceu logo depois da Segunda Grande Guerra mundial (19391945) nos principais países do mundo do capitalismo maduro. Nasceu como uma reação teórica e política ao modelo de desenvolvimento centrado na intervenção do Estado que passou a se constituir, desde então, na principal força estruturadora do processo de acumulação de capital e de desenvolvimento social. Considerando essa intervenção como a principal crise do sistema capitalista de produção, os neoliberais passaram a atacar qualquer limitação dos mecanismos de mercado por parte do Estado, denunciando tal limitação como uma ameaça letal à liberdade econômica e política. É nesse sentido que os neoliberais vão retomar a tese clássica de que o mercado é a única instituição capaz de coordenar racionalmente quaisquer problemas sociais.”. (p. 195).
} 
internos e externos, viram nas avaliações uma maneira de se manterem minimamente presentes e no controle.

Em resumo, como mostra Cunha (2010), o Estado, tomando para si uma lógica empresarial, passou, nesse contexto, a atuar "mais efetivamente dentro das instituições públicas, em especial nas educativas, pela introdução de novos sistemas gerenciais e pelo uso de estratégias de avaliação e autoavaliação, pautadas nas noções de eficiência e de qualidade dos serviços.” (p. 22). Esse novo modelo é chamado neste trabalho somente de Estado capitalista, mas salienta-se que, por suas características, ele é convencionalmente denominado Estado avaliador ${ }^{6}$. Nesse, observa-se a adoção de uma "lógica de mercado por meio de modelos de gestão privada com ênfase nos resultados para o sistema educativo.” (MENDES; FRANGELLA, 2014, p. 332). Sem intervenção estatal direta, buscava-se controlar a qualidade da educação com a introdução "de mecanismos de accountability ${ }^{7}$ baseados em testes estandardizados de alto impacto e em rankings escolares ${ }^{8}$, indutores de formas autoritárias de prestação de contas e de responsabilização das instituições, organizações e indivíduos". (AFONSO, 2013, p. 272).

Assim como qualquer empresa, as instituições educativas deveriam submeter-se aos critérios economicistas e gerenciais do mercado e, especificamente no que tange à educação superior, produzir mais com menos gastos. (DIAS SOBRINHO, 2004). Instrumento decisivo para a gestão estratégica, as avaliações converteram-se, nesse contexto, em uma estratégia de diminuição de gastos do Estado e aumento do controle por parte do mesmo. Por outro lado, não se pode ignorar que as avaliações também se transformaram na maneira encontrada para se alcançar uma educação de qualidade; afinal, a mão de obra necessária ao crescimento econômico precisava qualificar-se minimamente bem. Desse modo, as políticas avaliativas,

\footnotetext{
${ }^{6}$ O britânico Neave (1988) utilizou, pela primeira vez, a expressão Estado-Avaliador; e o chileno Brunner (1990) foi um dos pioneiros na transferência do conceito ao contexto latino-americano, de acordo com Yannoulas, Souza e Assis (2009). Esses últimos dizem que os "desafios em matéria de educação superior para os Estados latino-americanos teriam aumentado, após re-instauração das democracias, pois os sistemas de educação superior se massificaram e se diversificaram, num contexto de restrições orçamentárias próprias dos tempos neoliberais e ao mesmo tempo de liberdade e promoção de direitos civis e políticos. Essa situação teria causado a crise dos antigos modelos de relacionamento ente Estado e sociedade civil em matéria de educação superior. Nesse contexto, o Estado abandonou suas antigas funções educacionais e passou a regular a totalidade do sistema através de avaliações periódicas, alterando as distorções e injustiças que uma evolução totalmente autônoma produziria, e outorgando financiamento público negociado segundo metas e objetivos a serem atingidos.”. (p. 59-60).

${ }^{7}$ De acordo com Queiroz (2014), a accountability é uma “expressão usada no campo das políticas públicas de avaliação para se referir à prestação de contas ou como responsabilização em função de critérios ligados à eficiência e eficácia social." (p. 138).

${ }^{8}$ Os rankings são, conforme Queiroz (2014) "sistemas de classificação adotados em propostas de avaliação da educação, e cujo interesse principal é o estabelecimento de comparação entre instituições e ou cursos." (p. 139).
} 
inseridas no modelo de Estado capitalista, demonstram servir a dois fins: (i) diminuições de gastos por meio do aumento do controle estatal e (ii) fomento/manutenção de qualidade. Mas essas funções, longe de serem facilmente equalizáveis, são, em verdade, a representação do embate que gira em torno das políticas avaliativas. O Sinaes, e a autoavaliação, em específico, por exemplo, a que serve mais: ao controle ou à qualidade?

Nos países latino-americanos, entre os quais o Brasil, se começou a elaborar avaliações sistematizadas para a educação superior especialmente a partir da década de 1990 . (TAVARES et. al., 2011; MENEGHEL; ROBL; SILVA, 2006). A educação superior brasileira, especificamente, contou a princípio com o Programa de Avaliação da Reforma Universitária (Paru) e com o Grupo Executivo para a Reformulação do Ensino Superior (Geres), inaugurados, respectivamente, em 1983 e em 1986, antes, portanto, da época casual. Essas, vale dizer, foram propostas/ideias de avaliação e não exatamente avaliações que efetivamente vigoraram e se instituíram nacionalmente. (POLIDORI; MARINHO-ARAÚJO; BARREYRO, 2006).

Na década subsequente - 1990 - surgiram políticas avaliativas postas efetivamente em prática. Primeiramente foi introduzido em âmbito nacional, em 1993, o Programa de Avaliação Institucional das Universidades Brasileiras (Paiub), o qual tinha como foco a avaliação institucional e, especificamente, a autoavaliação. Esse teve forte aceitação das comunidades acadêmicas, mas não atingiu boa receptividade por parte do Estado e do próprio Ministério da Educação (MEC), tendo sido substituído quando do governo de Fernando Henrique Cardoso (FHC), em 1996, pelo Exame Nacional de Cursos (ENC). Bastante distinto do Paiub, o ENC, também chamado de "Provão", transferia práticas do mercado, como ranqueamento e competitividade, às Instituições de Educação Superior (IES); não levava em conta a autoavaliação; e tinha como foco a avaliação dos estudantes. A partir dos seus resultados, se subsidiava a elaboração, por parte da mídia, de listas de "melhores" cursos e "melhores" instituições, por exemplo.

O ENC esteve em vigor até 2004, quando foi substituído em abril desse ano, à época do governo de Luís Inácio Lula da Silva (Lula), pelo sistema avaliativo que está em vigor até o momento: o Sistema Nacional de Avaliação da Educação Superior. Esse último, não se diz controlador, mas emancipador; não propõe foco na avaliação do estudante, mas na da instituição, incluindo a autoavaliação; e, por fim, não apresenta uma avaliação isolada, mas 
um sistema ${ }^{9}$, interligado e dialógico. Contudo, o que garante que os sinais da prática coincidem com a proposta do Sinaes?

O Sistema Nacional de Avaliação da Educação Superior foi concebido pela Comissão Especial de Avaliação da Educação Superior (CEA), por norma das Portarias MEC/SESu de no 11 (BRASIL, 2003a) e de no 19 (BRASIL, 2003b), e instituído pela Lei no 10.861, de 14 de abril de 2004, (BRASIL, 2004a). Essa política é operacionalizada pelo Instituto Nacional de Estudos e Pesquisas Educacionais Anísio Teixeira (Inep), por meio da Diretoria de Avaliação da Educação Superior (Daes), segue as diretrizes definidas pela Comissão Nacional de Avaliação da Educação Superior (Conaes ${ }^{10}$ ) e, o mais importante: tem uma proposta de avaliação ao mesmo tempo formativa, regulatória e emancipadora. (TENÓRIO; ARGOLLO, 2009). Entre as principais ações necessárias à efetiva implantação de uma avaliação formativa para a educação superior à época em questão, pelo menos seis eram, de acordo com Ristoff (2004), primordiais:

(1) o deslocamento de centro de avaliação de uma prova para um conjunto diversificado de instrumentos, (2) a integração dos instrumentos de avaliação e de informação e dos processos avaliativos desenvolvidos por diferentes órgãos do Ministério da Educação e dos sistemas estaduais, (3) a valorização dos aspectos qualitativos e interpretativos nos processos e instrumentos, (4) a institucionalização de programas permanentes de capacitação de avaliadores, (5) a criação e consolidação da cultura de auto-avaliação nas Instituições de Ensino Superior, e (6) a implantação de processos de meta-avaliação. (p. 179).

Observa-se que a consolidação de uma cultura de autoavaliação aparece como necessidade primordial na visão de Ristoff (2004). Tomar para si essa e as demais responsabilidades significaria instaurar um sistema que, como a própria denominação já indica, não focaria em uma prova para o estudante ou em resultados mensuráveis e passíveis de ranqueamento, como no ENC, senão em um conjunto de instrumentos avaliativos interligados e com viés qualitativo. Ademais, significaria capacitar bem e constantemente os envolvidos com os instrumentos avaliativos; e sempre retroalimentar o sistema em prol de

\footnotetext{
9 Conforme o dicionário da língua portuguesa Houaiss, o substantivo "sistema" significa, entre outras considerações, (i) conjunto de elementos, concretos ou abstratos, relacionados entre si; e (ii) conjunto de unidades organizadas de determinada forma para alcançar um mesmo fim. (HOUAISS; VILLAR, 2008).

${ }^{10}$ A Conaes é formada por um colegiado representado por um presidente, por representantes com notório saber científico, filosófico e artístico, e reconhecida competência em avaliação ou gestão da Educação Superior, e por representantes do: Ministério da Educação, Instituto Nacional de Estudos e Pesquisas Educacionais Anísio Teixeira - Inep, Corpo Discente das Instituições de Educação superior, Corpo Docente das Instituições de Educação Superior, Corpo Técnico-Administrativo das Instituições de Educação Superior e da Fundação Coordenação de Aperfeiçoamento de Pessoal de Nível Superior - Capes. (CONAES, 2015).
} 
aperfeiçoamentos bem planejados, os quais levassem em consideração o que as IES necessitam.

O Sinaes é constituído por três grandes pilares, discutidos, de forma detalhada, no capítulo dois desta dissertação: (i) a Avaliação dos Cursos de Graduação (ACG), (ii) a Avaliação do Desempenho dos Estudantes (Enade), e (iii) a Avaliação das Instituições da Educação Superior (Avalies) - a última composta por avaliação externa e autoavaliação. A promessa era de um sistema estável e evoluído, o qual atenderia bem, portanto, as expectativas que se tinha para uma avaliação exemplar. Os resultados desses componentes avaliativos, tal como foram projetados, possibilitariam traçar um panorama da educação superior brasileira capaz de subsidiar, por parte das IES e das instâncias governamentais, tomadas de decisões conscientes e que visassem à qualidade.

A avaliação institucional, que abarca a autoavaliação, especificamente, aparece no projeto do Sinaes como o "instrumento central, organizador da coerência do conjunto.". (BRASIL/INEP, 2009, p. 102). Ela teria a finalidade de identificar o perfil das instituições e o significado da atuação dessas "por meio de suas atividades, cursos, programas, projetos e setores, considerando as diferentes dimensões institucionais”. (BRASIL, 2004a). Com exceção para os casos de instituições que possuem somente um curso, a avaliação institucional tem, pois, como foco principal do processo avaliativo as IES, e toma como base três aspectos:

a) o objeto de análise é o conjunto de dimensões, estruturas, relações, atividades, funções e finalidades de uma IES; dentre outros aspectos, ensinopesquisa-extensão, administração, responsabilidade e compromissos sociais, formação, etc; b) os sujeitos da avaliação são o conjunto de professores, estudantes, funcionários e membros da comunidade externa especialmente convidados ou designados; c) os processos avaliativos seguem os procedimentos institucionais e se utilizam da infraestrutura da própria instituição. (BRASIL, 2009, p. 102 - 104).

Já especificamente a autoavaliação, é um processo coordenado em cada IES do Sistema Federal de Ensino Superior ${ }^{11}$ por uma Comissão Própria de Avaliação (CPA). Essa seria formada proporcionalmente por representantes de quatro segmentos que constituiriam a instituição, a saber: docentes, discentes, técnicos administrativos e sociedade civil organizada. E o objetivo da comissão e, logo, da autoavaliação seria, conforme a Conaes:

\footnotetext{
11 O Sistema Federal de Ensino Superior compreende as instituições federais de educação superior, as instituições de educação superior criadas e mantidas pela iniciativa privada e os órgãos federais de educação superior, estando, portanto, as IES públicas municipais ou estatuais isentas da obrigatoriedade de participação no Sinaes e, consequentemente, na autoavaliação.
} 
[...] produzir conhecimentos sobre a realidade das IES; compreender os significados do conjunto das atividades para melhorar a qualidade educativa e alcançar maior relevância social; identificar as potencialidades e as fragilidades; aumentar a consciência pedagógica e a capacidade profissional do corpo docente e técnico-administrativo; fortalecer as relações de cooperação entre os diversos atores institucionais; tornar mais efetiva a vinculação com a comunidade; e prestar contas à sociedade. (BRASIL/INEP, 2011, p. 23).

Tal objetivo, por sua vez, deveria ser alcançado pela CPA a partir da consideração de algumas dimensões já pré-estabelecidas pela política do Sinaes. Até 2013 consideravam-se dez dimensões, a saber: (i) a missão e Plano de Desenvolvimento Institucional (PDI); (ii) a política para o ensino, a pesquisa, a pós-graduação e a extensão; (iii) a responsabilidade social da IES; (iv) a comunicação com a sociedade; (v) as políticas de pessoal, as carreiras do corpo docente e técnico-administrativo; (vi) a organização de gestão da IES; (vii) a infraestrutura física; (viii) o planejamento de avaliação; (ix) as políticas de atendimento aos estudantes; e (x) a sustentabilidade financeira. Já a partir de 2014, essas dez dimensões foram aglutinadas em cinco eixos, conforme a Portaria $n^{\circ}$ 92/2014 (BRASIL/MEC, 2014): (1) planejamento e avaliação institucional - que contemplam o projeto e o processo de autoavaliação; (2) o desenvolvimento institucional; (3) as políticas acadêmicas; (4) as políticas de gestão; e (5) a infraestrutura. (BRASIL/MEC, 2014). Esses eixos vão ao encontro do que Lehfeld et. al. (2010) dizem sobre o significado da avaliação institucional. Para o autor, avaliar uma instituição é lidar "não só com variáveis quantificáveis, mas com situações polissêmicas, incertas e dinâmicas. Significa levar em conta as contradições, a pluralidade de pontos de vista, a diversidade dos sujeitos, os elementos estruturais e conjunturais." (p. 178). Nada melhor do que a autoavaliação para levar em consideração essas questões.

Para a avaliação das IES nas dez dimensões ou, recentemente, nos cinco eixos, recomenda-se a consideração de três etapas: (i) a preparação, que passa por constituir uma CPA na IES, elaborar a partir das discussões dessa um projeto de avaliação; e, ainda, sensibilizar a comunidade acadêmica a respeito da importância da autoavaliação; (ii) o desenvolvimento, que se caracteriza como etapa em que sob a coordenação da CPA, se ausculta a comunidade, levantam-se informações e as analisa; e (iii) a consolidação, que seria tanto a elaboração do relatório, contendo, entre outras questões, as potencialidades e as fragilidades da IES, as ações e metas necessárias em prol de melhorias, como a implementação de ações por parte da gestão com base nos resultados. (BRASIL/Inep/Conaes 2004a). Usando os termos técnicos de Maba e Marinho (2012) para tal, pode-se dizer que "o processo avaliativo se desdobra (diagnóstico/prognóstico), o que dá lugar ao planejamento, 
que, por sua vez, divide a avaliação em somativa (produto) e reguladora (gestãoimplementação)" (p. 462). O "produto" é o relatório de autoavaliação, o qual deve ser postado anualmente no sistema e-MEC ${ }^{12}$. (BRASIL/MEC, 2007). E a "gestão-implementação" são as ações tomadas a partir dos resultados apontados pela CPA nos relatórios.

Em um plano ideal, em que tudo ocorre conforme planejado, a autoavaliação institucional e o Sinaes como um todo representariam uma ruptura à política avaliativa do ENC e a toda e qualquer postura com foco no controle. Seria a definitiva instauração de uma avaliação formativa, com vistas à emancipação das IES e ao alcance e continuidade da qualidade institucional, características discutidas no capítulo 1. Contudo, é preciso levar em conta três considerações antes de tomar como verdade absoluta e praticável a proposta do Sinaes.

Em primeiro lugar, e valendo-se de metáforas, é preciso considerar que um pilar sozinho é somente uma base, sendo necessárias ainda paredes e teto para se construir a casa. Consequentemente, a avaliação institucional, dita centro do Sinaes, depende da avaliação dos estudantes e dos cursos para dialogicamente adquirir seu posto central - aquele em que a autoavaliação é valorizada.

Em segundo lugar é preciso ter em mente que toda política pública implementada necessita de um tempo de conformação. Por muitos anos, prevaleceu, a exemplo do ENC, o foco no controle, sendo, pois, difícil a instauração instantânea de uma cultura de avaliação formativa. O fato de o Paiub não ter tido apoio do governo nem do MEC; o longo tempo de permanência do ENC; a desconsideração desse com a prática da autoavaliação; bem como tudo o que essa política avaliativa subsidiava - ranking e competição -, indicam que o controle tem sido predominante, como se verá nos capítulos um e dois. Desse modo, é difícil assegurar que desde o momento de inauguração do Sinaes esse tenha logrado romper com o passado recente e estabilizado, ou ainda que essa tenha sido a intenção.

Não suficiente, em terceiro lugar, é necessário levar em conta que no Brasil a implementação do ideário neoliberal, que serve de base ao uso das avaliações por parte do Estado, está presente em todos os governos. Sendo assim, em cada contexto histórico, político e econômico, o Estado capitalista brasileiro delinearia a política de avaliação da educação superior que mais se ajustaria ao projeto de sociedade almejado pelo sistema de produção.

\footnotetext{
${ }^{12} \mathrm{O}$ e-MEC é um sistema eletrônico de acompanhamento dos processos que regulam a educação superior no Brasil e está em funcionamento desde janeiro de 2007. Por meio dele, as IES podem abrir e acompanhar seus processos de regulamentação de forma simplificada e transparente via internet. Entre os processos encontra-se o credenciamento e o recredenciamento, o reconhecimento e a renovação de reconhecimento de cursos, assim como a postagem dos relatórios de autoavaliação. (MEC, 2015).
} 
(RODRIGUES, 2015). Mais do que estar em jogo, portanto, o cumprimento de uma proposta, está a intencionalidade política/econômica dos governantes. Segundo Ribeiro (2012), a concepção neoliberal teve início no Brasil

[...] nos governos de Collor de Mello (Março/1990-Dez/1992) e de Itamar Franco (Dez/1992-Jan/1995), mas se efetivou concretamente com o governo de Fernando Henrique Cardoso (Jan/1995-Dez/2002) e, contrariando as expectativas, o governo de Luís Inácio Lula da Silva (Jan/2003-Dez/2010) tem produzido algumas políticas de cunho social em resgate à função do Estado-providência: no entanto, os preceitos dessa doutrina neoliberal ainda são mantidos. (p. 303).

Nos dois mandatos do governo Luís Inácio Lula da Silva (2003-2006 e 2007-2010), em que foi instituído o Sinaes, e no primeiro mandato de sua sucessora, Dilma Rousseff (2011-2014), encontra-se, no que tange à educação superior, indícios de que o controle ainda prevalece. Mesmo tendo havido nesse período mais investimento na educação pública, como se verá no capítulo um, bem como não substituição do Sinaes por uma política como a do ENC, por exemplo, isso não é suficiente para a caracterização de uma inovação integral na política avaliativa brasileira, como se comprovará no decorer de todo o trabalho.

Com o Sinaes, esperava-se que o foco na avaliação institucional, tendo como destaque a autoavaliação, ajudasse a gerar a cultura de avaliação formativa nas IES. Mas faz-se difícil assegurar que passados doze anos de implementação do Sinaes (2004-2016) isso já tenha sido alcançado em plenitude. Não se pode garantir que, de fato, por exemplo, a qualidade educacional venha sendo viabilizada, nem que a autoavaliação tenha ganhado o destaque merecido. O Enade passou a ser, com o tempo, a principal fonte de informação para a formulação de índices de qualidade; e tudo indica que isso pode até ter desestimulado as IES a levarem com seriedade os processos de autoavaliação. (GARCIA; ESPINDOLA; SORDI, 2011; DIAS SOBRINHO, 2008).

O movimento da história mostra que grandes mudanças raramente ocorrem instantaneamente e que, no caso das políticas de avaliação brasileira, a autoavaliação ainda passa por consideráveis inconsistências. O Sinaes carrega, como se verá no capítulo dois, marcas das políticas avaliativas anteriores a ele; tem tido alguns de seus aspectos reformulados, o que mudou em parte sua proposta; e, conforme Sakamoto (2012), Dias Sobrinho (2010) e Vieira (2008), vem enfraquendo-se e burocratizando-se. Assim, por esses e outros motivos, esta pesquisa toma para si dois pressupostos. O primeiro é o pungente preterimento da autoavaliação, por meio do destaque dado ao pilar da avaliação dos 
estudantes, como se discute no capítulo dois. O segundo é a problemática que envolve o trabalho da CPA especialmente no que diz respeito a sua autonomia, já que suas eventuais determinações e conselhos, expressos nos relatórios, sempre passariam pelo crivo da gestão da instituição, como se discute no capítulo três.

Observam-se inconsistências em torno da prática da autoavaliação porque esse momento avaliativo, assim como qualquer ação de uma política pública, está inserido em um contexto de contradições; nesse caso, envolvendo as políticas públicas de educação e o Estado capitalista brasileiro, bem como a proposta da autoavaliação e a sua prática. Transitando, nos três capítulos, que constituem esta dissertação, por diversas contradições, a autora buscou responder ao problema que envolve o objeto: o lugar que o elemento historicamente subsumido - a autoavaliação institucional - ocupa na prática avaliativa, no contexto específico da UnB. Compreender como na prática o planejado pelo Sinaes para a autoavaliação se acomoda é de extrema importância, pois um elemento passível de tão boas contribuições à garantia e fomento da qualidade da educação não está sendo devidamente valorizado.

Mesmo a autoavaliação sendo prevista - já que inserida na avaliação institucional como o instrumento principal da política do Sinaes, a tese que orientou este estudo é que ela ainda precisa avançar, já que devido às marcas da subsunção do passado e do presente, não lograria exercer seu papel formativo intencional. Acredita-se que a autoavaliação ainda é um elemento frágil; e que isso não se atribui a algo específico que o Estado, uma IES ou uma CPA tenha feito. Fez-se necessário nesta pesquisa levar em consideração os contextos específicos emergidos do recorte empírico aqui adotado, considerando as múltiplas determinações que interferem na autoavaliação.

Questões norteadoras e objetivos - A fim de contextualizar as interferências que sofre o processo autoavaliativo, este estudo sobre a autoavaliação na Universidade de Brasília buscou responder à seguinte questão: em que proporção o previsto para a implementação da autoavaliação sob os moldes da política do Sinaes é ressignificado na prática da Universidade de Brasília?

Com efeito, para responder a essa questão norteadora, foi preciso centrar-se em três importantes pontos: (i) o significado atribuído nessa IES ao processo autoavaliativo; (ii) os relatórios produzidos por sua CPA; e (iii) o uso que a gestão faz dos resultados apontados nos relatórios. Esses pontos caracterizam direta ou indiretamente os momentos previstos para a autoavaliação: preparação, desenvolvimento e consolidação. Nesse sentido, tem-se as seguintes questões de apoio: (i) Quais elementos concorrem para a construção do significado 
que a comunidade acadêmica da UnB atribui à autoavaliação? (ii) Em que medida o processo de autoavaliação descrito nos relatórios de autoavaliação dessa universidade atendem a todas as dimensões que a política do Sinaes prevê? (iii) De que maneira os resultados da autoavaliação são utilizados, na visão da CPA, pela gestão dessa universidade? Para responder às questões apresentadas, foi preciso muito mais que verificar se a IES pesquisada seguia ou não as diretrizes do Sinaes para a autoavaliação; foi necessário perceber essas diretrizes no que Kosik (1976) chama de mundo real. Para esse filósofo tcheco, o mundo da realidade

[...] é o da práxis humana. É a compreensão da realidade humano-social como unidade de produção e produto, de sujeito e objeto, de gênese e estrutura [...] é o mundo em que a verdade não é dada e predestinada, não está pronta e acabada, impressa de forma imutável na consciência humana (p. 18-19).

A autora desta dissertação entende que o pré-fixado para a autoavaliação, ou para qualquer política pública em geral, se reconfigura na realidade; e resolveu, então, compreender o processo de ressignificação a partir do diálogo entre a literatura especializada da área e as vozes perscrutadas. Com essa postura, foi possível atender ao objetivo geral de compreender em que medida o previsto pelo Sinaes para a autoavaliação é ressignificado na prática da Universidade de Brasília. Os objetivos específicos, por sua vez - desdobramentos desse objetivo geral -, são: (i) Compreender os elementos que concorrem para a construção do significado que a comunidade acadêmica da universidade estudada atribui à autoavaliação; (ii) Analisar em que proporção o processo de autoavaliação descrito nos relatórios de autoavaliação dessa universidade atendem às dimensões da política do Sinaes; e (iii) Analisar como, na visão da CPA, os resultados da autoavaliação são utilizados pela gestão da universidade selecionada.

Tanto esses objetivos específicos como o geral têm relação direta com as perguntas de apoio apresentadas primeiramente, as quais foram exibidas antes dos objetivos, por sua vez, pela crença da autora de que para problematizar o objeto da pesquisa fora preciso primeiramente questionar, o que se faz melhor por meio de questões norteadoras. Chegar à delimitação dessas questões e objetivos apresentados, contudo, não foi uma decisão simples. A literatura especializada ajudou consideravelmente nisso, sobretudo aquela referente à trajetória das políticas avaliativas do Brasil; à diferença entre avaliações formativas e controladoras; e aos moldes da política do Sinaes para a autoavaliação. 
Relevância do estudo - Especialmente a partir da aproximação da autora à literatura referente às políticas de avaliação do Brasil, foi tomada a decisão de se estudar a ressignificação que a Universidades de Brasília, na figura de sua Comissão Própria de Avaliação, faz às propostas do Sinaes para a autoavaliação. E este estudo justifica-se exatamente pela relevância e pertinência dessa discussão na conjuntura do momento, em que está em vigor uma política avaliativa a qual dá destaque à avaliação institucional. É sabido que os objetivos de uma política pública nem sempre são alcançáveis na prática, logo, o movimento histórico é que indica o fim e a viabilidade da autoavaliação; sendo, portanto, muito instigante e desafiador percorrer esse caminho investigativo.

Em suma, o interesse por essa temática é proveniente de três dimensões, as quais se inter-relacionam e se completam em função da complexidade do tema. A primeira é a profissional; e salienta-se que apesar de a pesquisadora não ter tido, até então, relação direta de trabalho com a educação superior, suas experiências levaram-na a escolher pesquisar nessa área. Durante as graduações em Licenciatura em Língua Portuguesa e em Bacharelado em Estudos Literários, ambas concluídas em 2013, a mesma pesquisou o uso pedagógico dos resultados da Prova Brasil ${ }^{13}$, política que avalia, por meio de questionários socioeconômicos e testes padronizados elaborados a partir da Teoria de Resposta ao Item (TRI), a qualidade da educação básica. E desde setembro de 2015 a pesquisadora trabalha como professora na educação básica e pública do Distrito Federal, onde tem contato prático com políticas avaliativas. Isso motivou a que no mestrado ampliasse seu leque de conhecimento e de investigação às avaliações da educação superior e conhecesse, entre outras questões, a política avaliativa que poderá vir a acompanhar seus educandos. Na percepção macro de políticas de avaliação da educação, adquiridas pela pesquisadora na graduação e pós-graduação, a mesma enxerga a possibilidade de exercer, no futuro, funções que exijam esse conhecimento. Sendo o Sinaes um sistema grande e complexo, aderiu, contudo, a usual focalização em um momento avaliativo - a autoavaliação, vislumbrando na escolha desse momento a possibilidade de contribuir com o aperfeiçoamento da política pública, como um todo.

A segunda dimensão é a acadêmica e representa a oportunidade de, por meio desta pesquisa, vir a endossar ainda mais a literatura referente à política pública de avaliação e, especificamente, à autoavaliação. A UnB tem sido destacada como referência em pesquisas de

\footnotetext{
${ }^{13}$ Em 2012 a pesquisadora foi bolsista do Instituto Unibanco como integrante do projeto "Em busca de relações: o vínculo entre gestão, clima e desempenho escolar", coordenado pelo professor Dr. Wagner Silveira Rezente (UFJF). Em 2010 e 2011 foi bolsista da Fundação de Amparo à Pesquisa do Estado de Minas Gerais como integrante do projeto "Proficiência em Leitura: Interpretação Pedagógica dos Resultados da Prova Brasil", coordenado pela professora Dra. Maria Teresa Gonzaga Alves (UFMG).
} 
mestrado e de doutorado relacionadas ao Sinaes. Teixeira Júnior (2015) identificou 101 trabalhos desse tipo no âmbito de programas de pós-graduação das universidades de todas as regiões do Brasil, sendo que a "Universidade de Brasília (UnB) e a Universidade Federal do Ceará (UFC) são as instituições com maior número de produções sobre o Sinaes, seguidas por PUC São Paulo, Universidade Federal da Bahia e Unicamp.”. (p. 86). Desse total de trabalhos, o autor identificou que enquanto 68 são oriundos de orientadores diferentes (uma pesquisa para cada orientador), 33 foram orientados por apenas nove professores, sendo dois da $\mathrm{UnB}^{14}$. Tais achados apontam que poucos são aqueles professores que tomaram o Sinaes como um de seus objetos principais de interesse, mas que a UnB vem se constituindo como um núcleo representativo de pesquisas na área. Isso endossa a relevância acadêmica desta pesquisa como contribuinte do cenário de destaque ao qual a UnB se encontra.

Acrescenta-se ainda que, assim como Teixeira Júnior (2015), a pesquisadora desta dissertação também fez um levantamento bibliográfico de trabalhos relacionados ao Sinaes, contudo, o fez a partir dos pilares e componentes que compõem esse. Concomitantemente à pesquisa bibliográfica levantada sobre autoavaliação, por exemplo, também foram buscados trabalhos sobre o Enade. Especificamente no que tange a teses e dissertações, foram encontrados 45 pesquisas a respeito do Enade e 14 a respeito da autoavaliação; e percebeu-se que, ainda que os trabalhos encontrados representem apenas um recorte da quantidade real de pesquisas sobre esses assuntos, a diferença quantitativa é gritante. Uma temática tão relevante como a da autoavaliação requer mais pesquisas; e esta dissertação vem a colaborar academicamente com o atendimento a essa necessidade.

Já a terceira dimensão é a social e decorre do fato de os resultados desta pesquisa, somados aos outros resultados de trabalhos de mesma temática, poderem servir a importantes finalidades práticas em nível macro e micro. Entre elas, destaca-se no nível macro o aprimoramento da política do Sinaes, como um todo, por parte das instâncias responsáveis. A Conaes e o Inep, por exemplo, vêm fazendo estudos a fim de compor um panorama da autoavaliação no país, já que seria inviável a eles contemplarem, em suas pesquisas diagnósticas, todas as especificidades locais. Acredita-se que este estudo, somado aos demais, contribui em termos de aporte teórico para que essas instâncias baseiem suas decisões também nos contextos particulares de cada IES. Em nível micro, por sua vez, destaca-se a colaboração

\footnotetext{
${ }^{14}$ Há vários pesquisadores da temática do Sinaes em todo o país. Entre as 101 pesquisas provenientes de mestrado ou doutorado, identificadas por Teixeira Júnior (2015), 33 foram orientadas por apenas nove pesquisadores, sinalizando que poucos são os que têm a política avaliativa em vigência como um dos principais interesses de pesquisa. Entre esses, destaque especial é dado a dois pesquisadores da Universidade de Brasília: José Vieira de Sousa orientou nove trabalhos na área e Marília Fonseca três, segundo o referido autor.
} 
com o trabalho da CPA da UnB no sentido de que essa venha a compreender e até mesmo superar as dificultadas que possui. Ressalta-se que foram encontrados somente dois estudos com foco na autoavaliação da universidade do corpus ${ }^{15}$ - o de Lourenço (1998), sobre o uso dos resultados da avaliação do ensino de graduação desenvolvida no período de 1987 a 1993, e o de Bedritichuk (2015), sobre o instrumento de avaliação docente utilizado pela CPA. Isso corrobora ainda mais a função social deste trabalho.

Vereda metodológica percorrida - Diante da amplitude social que os resultados desta pesquisa são passíveis de atingir, a pesquisadora tem o desafio da "constituição de um quadro de análise sistêmica da ação pública, que possa ultrapassar os limites da abordagem sequencial”. (MULLER; SUREL, 2002, p. 12). Isso significa enxergar a análise da política na singularidade e complexidade dessa e não como uma sequência de ações/etapas lineares que necessariamente deveriam levar, neste caso, aos contornos do Sinaes e, especificamente, da autoavaliação.

Quando se pensa em uma política avaliativa da educação superior de um país, a complexidade é algo inerente, o que faz necessário o esforço em compreender que todos os documentos relacionados à autoavaliação, bem como as pessoas envolvidas nessa, estariam inseridos em um contexto de contradições envolvendo a política pública e o Estado capitalista. Assim, mais do que contrastar o idealizado pela política do Sinaes e o de fato praticado na UnB, a pesquisadora se dispôs a desenvolver este trabalho tendo como base um olhar dialético.

A adoção desse olhar determinou tanto a postura da pesquisadora diante do objeto, como o que a mesma pretendeu com os resultados da pesquisa. Esse olhar é aquele que foca no aprofundamento na realidade empírica e na relação do sujeito com o objeto; logo, significou, no contexto desta pesquisa, a busca pela compreensão da autoavaliação como prática social construída por sujeitos históricos. À luz das experiências captadas sobre a autoavaliação em um contexto geral e no contexto específico da UnB, o olhar dialético

\footnotetext{
${ }^{15}$ A busca por trabalhos científicos que abordassem a temática da autoavaliação no Brasil e especificamente na UnB foi realizada nos repositórios Google Acadêmico e Domínio Público - sites de busca de trabalhos acadêmicos -; (ii) no Banco de teses e dissertações da Coordenação de Aperfeiçoamento de Pessoal de Nível Superior (Capes); na Biblioteca Digital Brasileira de Teses e Dissertações (BDTD), vinculada ao Instituto Brasileiro de Informação em Ciência e Tecnologia (IBICT); no Repositório Institucional da Universidade de Brasília (RiUnB); (vi) na Biblioteca Digital de Teses e Dissertações da Universidade de São Paulo (USP); e ainda (vii) na Revista de Avaliação da Educação Superior - revista eletrônica publicada pela Universidade de Sorocaba. Entre os achados, destaca-se o estudo de Sousa (2013), que entre outras contribuições, traz um levantamento dos estudos produzidos sobre a educação superior do DF no PPGE/UnB entre 2008 e 2011. Dos dez trabalhos catalogados pelo autor, dois tinham como locus de pesquisa a UnB, um tendo como tema as estratégias de gestão dos cursos de especialização dessa instituição e outro o uso dos resultados do Exame Nacional de Desempenho dos Estudantes nos cursos de Física da mesma.
} 
auxiliou a apreensão da ressignificação da autoavaliação. Assim, tanto apontou elementos que ajudaram a desvendar o real, como deu base a que os resultados se tornassem passíveis de subsidiar transformações no processo autoavaliativo da IES do corpus.

Adotar um olhar dialético pressupôs que a pesquisadora procurasse ater-se à captura da essência do objeto por meio da abstração. Como mostra Gil (2008, p. 14), "os fatos sociais não podem ser entendidos quando considerados isoladamente, abstraídos de suas influências políticas, econômicas, culturais etc.”. Desse modo, entendeu-se que a autoavaliação institucional deveria ser estudada tomando como foco a captura de sua essência. Como a realidade é, no entanto, segundo Kuenzer (2011),

[...] um todo indivisível de entidades e significados, só é possível isolar uma dimensão para análise, através de um modo específico de apropriação, mediante a abstração. Sem esta compreensão corre-se o risco, como faz o positivismo, de considerar uma certa imagem da realidade como a realidade mesma, e um determinado modo de apropriação da realidade como único verdadeiro (p. 59).

O ideal foi sempre partir do observável, no caso, a autoavaliação na Universidade de Brasília, rumo à essência desse momento avaliativo; e cuidar que o objeto não seja considerado uma verdade absoluta, ou um todo acabado, transparente e autoexplicativo a partir do qual a pesquisa tem que partir. O movimento deve ser inverso e o foi, pois a abstração se dá na busca do conhecimento concreto do objeto, o qual nada mais é que o entendimento "das suas múltiplas determinações - tanto mais se reproduzem as determinações de um objeto, tanto mais o pensamento reproduz a sua riqueza (concreção) real.”. (PAULO NETTO, 2011, p. 45).

O caminho da abstração, no entanto, não é algo claro a priori. Primeiramente, foi necessário identificar o nível de totalidade que o objeto analisado - a autoavaliação requeria; para, com isso, compreender o melhor caminho a se tomar.

Se eu estou empenhado em analisar as questões políticas que estão sendo vividas pelo meu país, o nível de totalização que me é necessário é o da visão de conjunto da sociedade brasileira, da sua economia, da sua história, das suas contradições atuais. Se, porém, eu quiser aprofundar a minha análise e quiser entender a situação do Brasil no quadro mundial, vou precisar de um nível de totalização mais abrangente: vou precisar de uma visão de conjunto do capitalismo, da sua gênese, da sua evolução, dos seus impasses no mundo de hoje. E, se eu quiser elevar a minha análise a um plano filosófico, precisarei ter, então, uma visão de conjunto da história da humanidade. (KONDER, 1991, p. 39). 
No caso desta pesquisa, em que há o empenho em analisar a autoavaliação na prática da UnB, o nível de totalização necessário só poderia ser, na visão da pesquisadora, o da visualização: (i) do papel do Estado brasileiro nas políticas públicas de educação superior, (ii) do papel da avaliação da educação superior e (iii) do papel da autoavaliação no contexto do Sinaes e especificamente da IES em questão, identificando algumas contradições que envolvem e determinam o momento vigente e os passados. A compreensão foi, portanto, a de que "as determinações abstratas conduzem (führen) ao concreto, não como gênese do concreto, mas apenas como caminho de seu conhecimento pelo pensamento." (OLIVEIRA, 2009, p. 33).

Para realizar as análises feitas e sistematizar as informações adotou-se a abordagem qualitativa, a qual emergiu como a mais apropriada à manutenção do olhar impresso aqui. Essa abordagem pode ser considerada um estudo dinâmico, flexível, em que

[...] o raciocínio é dialético e também fenomenológico, a visão da realidade é o todo, sendo subjetiva, múltipla e analisada a partir da visão dos sujeitos. $\mathrm{O}$ pesquisador interage com os sujeitos pesquisados. As definições evoluem a partir dos estudos realizados. (SOUZA; FEITOSA, 2012, p. 33).

Adotando a abordagem qualitativa (CRESWELL, 2010), esta pesquisa apresenta: (i) uma coleta de dados realizada pela própria pesquisadora e feita diretamente no local em que os participantes vivenciam a questão - na UnB; (ii) múltiplas fontes de dados - Constituição Federal (CF), Lei de Diretrizes e Bases da Educação Nacional (LDBEN), primeiro e segundo Plano Nacional de Educação (PNE), relatórios de autoavaliação referentes aos anos de 2014 e de 2015, PDI 2014-2017, atas da Conaes e entrevistas; e (iii) foco no significado que os participantes dão à autoavaliação.

Essas características pontuadas foram contempladas com foco em uma única instituição - a UnB -, consequentemente, foi mais adequado adotar o tipo de pesquisa denominado "estudo de caso único" (YIN, 2001). Apesar de existirem tipos de estudos que focalizam mais de uma instituição, os mais usuais

[...] são os que focalizam apenas uma unidade: um indivíduo (como os "casos clínicos" descritos por Freud), um pequeno grupo (como o estudo de Paul Willis sobre um grupo de rapazes da classe trabalhadora inglesa), uma instituição (como uma escola, um hospital), um programa (como o Bolsa Família), ou um evento (a eleição do diretor de uma escola). (ALVESMAZZOTTI, 2006, p. 640-641). 
O estudo de caso, segundo Yin (2001), é uma pesquisa empírica que "investiga um fenômeno contemporâneo dentro de seu contexto da vida real, especialmente quando os limites entre o fenômeno e o contexto não estão claramente definidos." (p. 32). Para o autor, há críticos que por basearem-se em pesquisas com generalizações estatísticas, defendem que estudos envolvendo um caso específico não dariam base a generalizações. No entanto, a generalização realizada aqui é analítica. Nessa, “o pesquisador está tentando generalizar um conjunto particular de resultados a alguma teoria mais abrangente.” (p. 58).

Embora o estudo de caso em questão trate da autoavaliação na prática da Universidade de Brasília, do que se infere que a Comissão Própria de Avaliação dessa universidade é posta em foco, vale dizer que a pesquisa envolveu mais de uma unidade de análise. Além de membros da CPA da UnB, foram auscultados pesquisadores da temática da avaliação e representantes da Daes/Inep e da Conaes. Desse modo, com base na classificação de Yin (2001), esta pesquisa pode ser classificada como estudo de caso único com enfoque incorporado, já que a autoavaliação foi analisada a partir de diferentes unidades ou níveis de análise.

Valendo-se, assim, de um olhar dialético, da abordagem qualitativa e do estudo de caso único, com enfoque incorporado, este estudo foi empreendido por meio de duas etapas que se inter-relacionaram e se complementaram. A primeira constituiu na pesquisa bibliográfica realizada em livros, repositórios de busca e bibliotecas digitais. A segunda na pesquisa de campo, a qual também incluiu a análise documental.

O propósito da análise documental, para Bardin (2004), "é o armazenamento sob uma forma variável e a facilitação do acesso ao observador, de tal forma que este obtenha o máximo de informação (aspecto quantitativo), com o máximo de pertinência (aspecto qualitativo)." (p. 40). Seguindo essa perspectiva, foram realizadas entrevistas semiestruturadas (roteiros anexos) com agentes que possuem níveis diferentes de envolvimento com a autoavaliação, que vai desde uma relação mais teórica até a mais prática. As falas extraídas das entrevistas foram analisadas a fim de se identificar os temas - ou unidades de significação -, que naturalmente emergissem. (BARDIN, 2004).

As análises das informações colhidas nessas etapas, por sua vez, foram realizadas a partir de categorias metodológicas e de conteúdo (KUENZER, 2011), as quais são detalhadas na sequência. E espera-se que os resultados a que se chegou deem base a proposições teóricas que possam ser igualmente aplicáveis a outros contextos educacionais brasileiros, na medida do possível. 
Categorias de análise - $\mathrm{O}$ uso de categorias contribui consideravelmente para a condução de uma pesquisa, já que orienta o pesquisador na interpretação e análise do material coletado, bem como na organização dos tópicos prioritários ou secundários do trabalho. Elas "não são fragmentadas, se completam e estão articuladas como uma relação mútua e permitem uma visão mais compreensível do real.”. (SOUZA; OLIVEIRA, 2012, p.13).

São três as categorias teórico-metodológicas nucleares para a perspectiva dialética: contradição, mediação e totalidade e, nesta pesquisa, as duas primeiras foram contempladas, o que forneceu subsídios a uma relação crítica da pesquisadora com o objeto. A contradição, de acordo com Kuenzer (2011), é aquilo inerente ao movimento da história. A realidade não é única, pré-determinada ou proveniente de fenômenos imutáveis, logo, não é possível negar a existência e importância da contradição. Historicamente, fatos se opõem dialeticamente, "um incluindo-se/excluindo-se no/do outro, se destroem ou se superam; as determinações mais concretas contêm, superando-as, as determinações mais abstratas". (p. 65). Em suma, a realidade é composta de relações antagônicas entre elementos que se completam e se exluem mutuamente.

Nesta dissertação, a contradição é destacada em todos os capítulos. Transversalmente neste trabalho perpassa-se por tensões dialéticas entre a expansão da educação superior e as diferenças inerentes às IES pertencentes a classificações acadêmico-administrativa distintas; entre as diversas finalidades a que se prestaram as políticas avaliativas existentes para a educação superior e a diferença entre o projetado para o Sinaes quando de sua inauguração e os contornos que a política foi ganhando com o tempo; e ainda entre os dizeres dos entrevistados e o praticado pelos grupos aos quais os mesmos pertencem, por exemplo. $\mathrm{Na}$ problematização dessas e de outras contradições encontra-se a percepção do real por parte da autora do trabalho e dos interessados que recorrerão ao mesmo, assim como a reflexão dos agentes da UnB acerca do contexto em que estão inseridos.

A mediação, de acordo com Paulo Netto (2011), "reside em descobrir as relações entre os processos ocorrentes nas totalidades constitutivas tomadas na sua diversidade e entre elas e a totalidade inclusiva que é a sociedade burguesa. Tais relações nunca são diretas; elas são mediadas". (p.57). Não criar pontes de relações entre os elementos que influenciam o objeto da pesquisa seria esvaziar o sentido e a colaboração de cada temática. Assim, com a convicção de que tudo está dialeticamente conectado, nesta dissertação se concilia o todo com as partes de forma a não deixar nenhum fenômeno isolado.

A mediação foi contemplada no trabalho a partir da tentativa de se dar movimento à problematização e à busca da essência do objeto, conectando-se os dados. Como mostra Cury 
(1986, p. 44), "sem as mediações as teorias se tornam vazias e inertes, e, sem as teorias, as mediações se tornam cegas ou caolhas". Assim, a bibliografia especializada, as falas das entrevistas realizadas, bem como os documentos oficiais apurados foram dialeticamente mediados, levando-se sempre em consideração a historicidade que perpassa todos essas fontes. Por esse caminho, as relações contraditórias entre os estudos, sujeitos e leis, por exemplo, foram colocadas em foco.

A totalidade, por fim, apesar de não ser uma das categorias elencadas na análise do objeto desta pesquisa, perpassou grande parte das reflexões aqui levantadas. Longe de ser o domínio e exposição de todos os fatos, ela é, de acordo com Kuenzer (2011), a relação entre esses fatos, sempre tendo o movimento da história como parâmetro. Nesta pesquisa, entendese que a contradição e o movimento estão inseridos dentro da totalidade; logo, aqui se passou, indiretamente, por essa última categoria a partir do modo como se articulou as duas outras desde a introdução até a conclusão. A realidade, como diz Griboski (2014), é sempre maior do que o conhecimento que se tem dela, mas a análise do objeto, sob uma visão de conjunto, permite a contemplação da totalidade - categoria pela qual esta dissertação apenas perpassa.

Assim, valendo-se das categorias metodológicas da contradição e da mediação e ainda perpassando pela totalidade, a pesquisa pretendeu estabelecer um rigor metodológico capaz de corroborar a análise dialética das informações sobre a autoavaliação na prática da Universidade de Brasília. E para garantir o subsídio de conclusões com potencial transformador da realidade social, também foram estabelecidas categorias de conteúdo - essas últimas, definidas pela aproximação à temática da autoavaliação e ao movimento histórico dos acontecimentos. São elas: regulação, avaliação formativa e qualidade da educação superior selecionadas a priori - e relatórios de autoavaliação reduzidos ao cumprimento burocrático a posteriori.

A regulação foi problematizada na pesquisa como um tema controverso, já que muitas vezes tem grande interface com a avaliação, juntando-se a essa última (MENEGHEL; ROBL; SILVA, 2006). Com base no aporte teórico, a regulação é aqui entendida como prática inerente ao Estado, mas um momento posterior e dependente da avaliação, não devendo ser utilizada para o simples controle das instâncias educacionais.

A avaliação formativa é vista como um tipo ideal de avaliação muito bem representada pela proposta da autoavaliação institucional. Toda prática avaliativa envolve a atuação de múltiplos atores e ainda pode carregar as marcas de avaliações teoricamente já superadas. Desse modo, essa categoria foi trabalhada neste trabalho tendo em vista o contraste entre a proposta do Sinaes e sua prática, em que a autoavaliação pode estar sendo subsumida. 
Finalmente, a categoria qualidade da educação superior foi caracterizada como algo cujos significados são polissêmicos. Não há um consenso sobre o que seja de fato qualidade, logo, sua caracterização é dependente do que cobra a avaliação que estiver em vigor e do que pensam os sujeitos envolvidos em uma IES determinada, por exemplo.

No momento da análise empírica dos dados coletados a partir de entrevistas realizadas e de análise de documentos, uma categoria a mais emergiu no contexto da pesquisa, sendo, pois, acrescentada a posteriori. Um tema identificado como recorrente foi "relatórios de autoavaliação reduzidos ao cumprimento burocrático". Assim, esse também foi incluído como categoria de conteúdo.

Articulando-se as categorias de conteúdo (regulação, avaliação formativa, qualidade da educação superior e relatórios de autoavaliação reduzidos ao cumprimento burocrático) às metodológicas, da perspectiva dialética (contradição e mediação), foi possível analisar como a autoavaliação vem sendo ressignificada.

Instituição selecionada - A pesquisa empírica foi realizada tomando como base quão significativa a experiência autoavaliativa de determinada instituição seria à pesquisa. Como a prática autoavaliativa pressupõe autonomia por parte da IES e especificamente da CPA durante o processo, optou-se por escolher uma instituição classificada como universidade, entendendo que essas já têm a autonomia como prerrogativa para outras práticas ${ }^{16}$. Entre as universidades do país, a Universidade de Brasília possui renomada historicidade na autoavaliação, assim, com base no critério de relevância, foi imediatamente selecionada. $\mathrm{O}$ nome dessa instituição, por sua vez, foi divulgado neste trabalho por a autora acreditar que fazê-lo contribui com o fomento da transparência do processo de autoavaliação e popularização de seus respectivos resultados ${ }^{17}$. A ilustração 1 , a seguir, apresenta o mapa com a localização dos quatro campi da UnB localizados tanto em Brasília, como em outras Regiões Administrativas (RA) do Distrito Federal.

\footnotetext{
${ }^{16}$ No que diz respeito à classificação acadêmico-administrativa, as IES podem receber quatro denominações de acordo com a Lei de Diretrizes e Bases da Educação Nacional, de 1996: universidade, centro universitário, faculdade e instituto federal. (BRASIL, 1996). A universidade, além de ter que subsidiar ensino, pesquisa e extensão, é "autônoma para criar cursos e sedes acadêmicas e administrativas, expedir diplomas, fixar currículos e número de vagas, firmar contratos, acordos e convênios, entre outras ações, respeitadas as legislações vigentes e a norma constitucional.”. (MRE, 2016, p. 1).

17 Outras pesquisas com foco na autoavaliação também divulgaram os nomes das IES que lhes serviram de corpus. A título de exemplificação têm-se os artigos científicos de Adriola e Souza (2010), com a Universidade Federal do Ceará; o de Sousa, Marcondes e Acosta (2008), com a Pontifícia Universidade Católica de São Paulo; e Almeida, Pinto e Picoli (2007), com foco na autoavaliação da Universidade Federal do Rio Grande. Entre os trabalhos do tipo dissertação, cita-se Maba (2010) com seis Faculdades de Tecnologia pertencentes à administração Regional do SENAC de Santa Catarina; e Nascimento (2008), que tem como corpus a Universidade Estadual de Goiás. Já entre trabalhos do tipo tese, destaca-se o de Ribeiro (2010) com o Centro Universitário do Planalto de Araxá e com o Centro Federal de Educação Tecnológica de Minas Gerais - campi Araxá.
} 
Ilustração 1 - Mapa da localização geográfica dos campi da universidade selecionada para a pesquisa

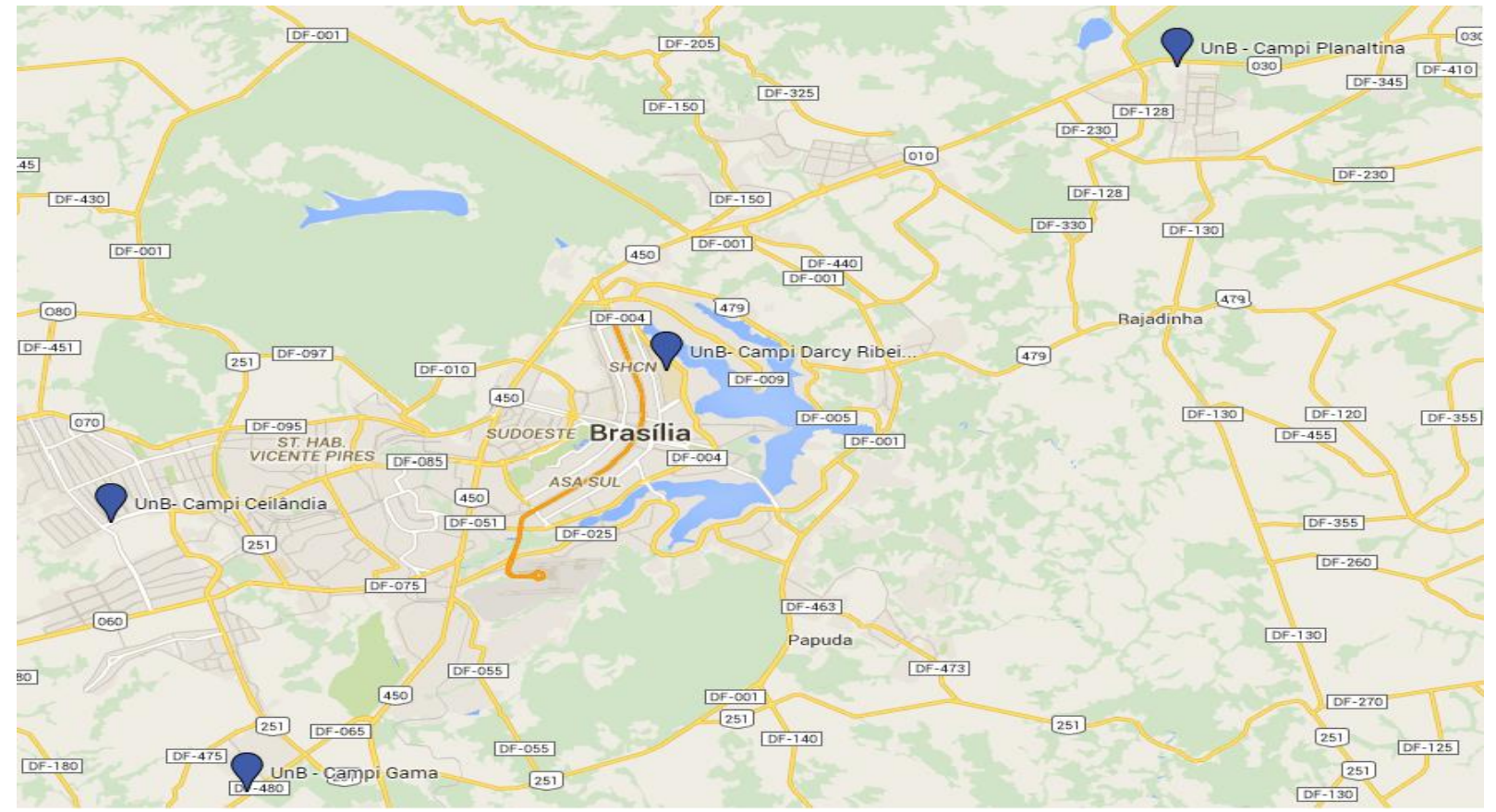

Fonte: Elaboração própria em Google Maps.

A Universidade de Brasília, cuja sede localiza-se em Brasília, especificamente na Asa Norte, (ver nota 1, na página 15, sobre o Distrito Federal e Brasília), foi inaugurada em 21 de abril de 1962 em virtude, especialmente, segundo Miglievich-Ribeiro (2012), da necessidade de que se instalasse na nova capital do Brasil um assessoramento intelectual e científico aos poderes públicos lá alocados.

Essa foi a primeira universidade brasileira que não foi criada a partir da aglutinação de faculdades pré-existentes; sua estrutura era integrada, flexível e moderna e contrapunha-se à universidade segmentada em cursos profissionalizantes. Seguindo o modelo norte-americano, organizou-se na forma de fundação e os departamentos substituíram as cátedras. (OLIVEN, 2002, p.38).

Assim, no mesmo ano de sua inauguração foi criada a Fundação Universidade de Brasília (FUB), a qual, entre outras funções, deveria, de acordo com a Lei no 3.998 de 15 de dezembro de 1961, manter a instituição. (BRASIL, 1961). Ela é responsável, portanto, "pelo gerenciamento do patrimônio e das receitas e despesas da UnB, mas não trata de questões acadêmicas. A FUB representa o que se pode considerar, em seu estatuto de criação, a mantenedora da UnB." (TRIGUEIRO, 2002, p. 124). 
De acordo com o PDI 2014-2017 da universidade, essa surgiu como produto do trabalho de três profissionais renomados: (i) o antropólogo Darcy Ribeiro, responsável pela definição das bases da instituição; (ii) o educador Anísio Teixeira, cuja missão fora elaborar o modelo pedagógico institucional; e (iii) o arquiteto Oscar Niemeyer, que projetou as formas físicas dos prédios. (UnB, 2014).

Atualmente, a universidade conta com quatro campi - a sede, localizada na Asa Norte, que abriga 125 cursos de graduação, e os campi das RA de Ceilândia, Planaltina e Gama, com seis cursos cada um. (UnB, 2016). Além disso, oferece cursos a distância desde a década de 1980, sendo uma das pioneiras nesta modalidade educacional, no país. (MORAN, 2002). As áreas de atuação acadêmica, por sua vez, estão distribuídas em nove grandes áreas de conhecimento. São essas: Ciências Exatas e da Terra, Ciências Biológicas, Engenharias, Ciências da Saúde, Ciências Agrárias, Ciências Sociais Aplicadas, Arquitetura e Urbanismo, Ciências Humanas e Linguística, Letras e Artes. É possível ingressar a um curso de uma dessas áreas por meio do Programa de Avaliação Seriada (PAS) - inaugurado em 1996 e destinado aos estudantes do ensino médio regular -, do vestibular anual, e ainda por meio da seleção do Exame Nacional de Ensino Médio - ENEM.

A missão da universidade, conforme seu PDI em vigência, é lograr ser "uma instituição inovadora, comprometida com a excelência acadêmica, científica e tecnológica formando cidadãos conscientes do seu papel transformador na sociedade, respeitadas a ética e a valorização de identidades e culturas com responsabilidade social.”. Complementarmente, a instituição estabelece como visão de futuro "estar entre as melhores universidades do Brasil, inserida internacionalmente, com excelência em gestão de processos que fortaleça ensino, pesquisa e extensão.”. (UnB, 2014, p. 19).

Para a formação dos estudantes, a UnB conta com uma gama de professores capacitados. Conforme seu PDI, em 2008 a instituição apresentava 1.297 docentes, mas com a consolidação do Programa de Apoio a Planos de Reestruturação e Expansão das Universidades Federais - Reuni - o quadro docente expandiu 82\% até 2014. (UnB, 2014). Em 2015, segundo dados do anuário estatístico da UnB explanados no último relatório de autoavaliação, há na instituição 400 professores substitutos ou visitantes e 2.826 professores servidores, sendo 2.295 doutores $^{18}$, 490 mestres, 21 especialistas e 20 somente com graduação. (UnB, 2016).

\footnotetext{
${ }^{18}$ Em 2014 havia 383.386 funções docentes em exercício na educação superior no Brasil. A maioria das funções docentes nas universidades, por sua vez, tem doutorado - 50,1\%; já nas faculdades, o percentual é de $15,7 \%$. Nessas últimas, o que prevalece são funções docente "até especialização" - 39,5\%. (INEP, 2015).
} 
O processo de avaliação institucional realizado na Universidade de Brasília, por sua vez, o qual, como se sabe, inclui a autoavaliação, data de antes da institucionalização da política do Sinaes, sendo que, juntamente com o realizado pela Universidade de Campinas (Unicamp), serviu até de referência à política avaliativa vigente. (SOARES NETO, et. al., 2013; BELLONI, 1999). No documento "Diretrizes para a avaliação das instituições de educação superior", publicado em 2004, por exemplo, faz-se alusão ao pioneirismo da UnB, conforme se pode observar a seguir:

O relatório final - Sistema Nacional de Avaliação da Educação Superior (SINAES): bases para uma nova proposta de avaliação da educação superior - expressa o resultado da experiência de avaliação desenvolvida e acumulada pelas instituições de educação superior, em nosso país [...]. Desde experiências pioneiras em algumas universidades - da UnB à UNICAMP até o amplo processo de avaliação institucional desencadeado, na década de 90, pelo Programa de Avaliação Institucional das Universidades Brasileiras (PAIUB). (BRASIL/Inep/Conaes, 2004a, p. 4).

A UnB inaugurou seu processo de avaliação institucional em 1986, tendo Cristovam Buarque como reitor (1985-1989), e a Unicamp em 1991, com Carlos Vogt (1990-1993), a partir da concepção e respectiva coordenação dos pesquisadores Isaura Belloni ${ }^{19}$ e José Dias Sobrinho $^{20}$. O que essas instituições realizaram em termo de avaliação serviu de parâmetro à formulação do Sinaes, tamanha a popularidade da UnB e da Unicamp e a importância de ter a primeira como corpus desta pesquisa.

O ano de 1986 marcou a história da instituição com a criação de sua Comissão de Avaliação Institucional (CAI), composta por Isaura Belloni, Oscar Serafini e Bernardo Kipnis - todos pesquisadores da Faculdade de Educação -, e ainda por Jorge Alberto Cordon

\footnotetext{
${ }^{19}$ Isaura Belloni (1943-2010) realizou doutorado e mestrado em Educação pela Universidade de Stanford, nos Estados Unidos da América, sendo uma das maiores referências como articuladora das políticas da educação brasileira. Foi professora da Faculdade de Educação (FE) da UnB e pesquisadora associada do mestrado em Educação da mesma. Inaugurou a avaliação institucional na referida universidade, tornando-a pioneira nisso; e ainda foi membro fundador do Programa de Avaliação Institucional da Universidade Brasileira (Paiub). Não suficiente, a pesquisadora foi consultora parlamentar da Câmara dos Deputados; defendeu a educação pública junto ao Núcleo de Educação, Cultura e Esporte do Partido dos Trabalhadores no Congresso Nacional; dirigiu a Secretaria de Estado de Educação do Distrito Federal (SEEDF); fora representante do caderno do Centro de Estudos Educação e Sociedade (Cedes), do qual era sócia; e ainda contribuiu com a elaboração e com a implementação do Sistema Nacional de Avaliação da Educação Superior.

20 José Dias Sobrinho é professor titular do Programa de Pós-graduação em Educação da Universidade de Sorocaba (Uniso) e aposentado da Unicamp, onde foi Pró-Reitor de Pós-graduação e Diretor da Faculdade de Educação. Realizou doutorado em Educação pela Unicamp (1975) e pós-doutorado pela École des Haute Etudes en Sciences Sociales de Paris (1979), além de ter presidido a Comissão Especial de Avaliação em 2003. Tem sido consultor da Global University Network for Innovation (GUNI-UNESCO) e do Instituto Internacional de Educación Superior para América Latina y el Caribe (IESALC-UNESCO).
} 
Portilho, da Faculdade de Ciências da Saúde ${ }^{21}$. (BELLONI; KIPNIS; SERAFINI, 1980). Esse grupo fora responsável por elaborar e testar uma proposta de metodologia de avaliação institucional para a instituição, a qual foi chamada de "Proposta de Avaliação de Instituições de Ensino Superior”. Ela foi aprovada em 1987 pelo Conselho de Ensino, Pesquisa e Extensão (CEPE) da IES e "se caracterizava por uma combinação de autoavaliação com avaliação externa, pela utilização de diversas fontes de informação, avaliadores para cada dimensão em foco e pela observação continuada.” (SOARES NETO et. al., 2013, p. 3).

Basicamente, a proposta tinha dois objetivos imprescindíveis: "a necessidade de se atingir uma autoconsciência institucional e fornecer subsídios confiáveis para tomada de decisão.”. (BELLONI; KIPNIS; SERAFINI, 1980, p. 16). Segundo os mesmos autores, em 1987 a ideia foi posta em prática e houve a primeira aplicação da proposta avaliativa, a qual contou com a colaboração de oito departamentos, 65 docentes e 979 estudantes avaliando 82 disciplinas e os respectivos docentes. Entre as perguntas abordadas nos questionários aplicados na ocasião, uma única era aberta, qual seja: "o que você acha da ideia de se avaliar a UnB?". Do total de respondentes, 65\% consideraram a ideia boa, sendo que a resposta afirmativa dos professores (90\%) fora maior do que a dos estudantes (63\%). Do conjunto de justificativas apresentadas pelos respondes para a importância de se avaliar a instituição, a que mais teve incidência de respostas foi a de que a avaliação garantiria a melhoria da qualidade do ensino, identificada em $73 \%$ das razões enumeradas. De fato, a proposta avaliativa era atrativa e passível de boa aceitação, já que buscava avaliar a IES globalmente. Nela incluía-se

[...] a avaliação do ensino (graduação e pós-graduação), do desempenho técnico científico, das atividades de extensão, da administração, dos colegiados acadêmicos e dos órgãos de apoio (biblioteca, centro de processamento de dados, editora etc.) Cada uma dessas dimensões seria avaliada quanto às condições para seu desenvolvimento, os processos desenvolvidos e os resultados obtidos. (BELLONI et. al. 1995, p. 92).

A avaliação do ensino, especificamente, de 1987 a 1992, incidia no desempenho docente para a progressão funcional. (LOURENÇO, 1998). Atitudes como essa, somada aos objetivos e ao alcance da avaliação institucional empreendida, fez com que a participação da comunidade acadêmica crescesse gradativamente ao longo dos anos concomitantemente ao

\footnotetext{
${ }^{21}$ Até o ano de 1993 a composição da equipe da CAI alterou-se com a saída de alguns membros e entrada de outros. "Sairam: prof. Oscar Serafini, prof. Jorge A. Cordon Portilho. Ingressaram: prof. José Ângelo Belloni, do Departamento de Estatística; profa. Mariza Monteiro Borges, do Instituto de Psicologia; prof. Dejano Sobral, da Faculdade de Ciências da Saúde. Além dos professores citados ingressaram os técnicos: Lúcia Franca Rocha (mestre em educação); Olímpio Sabino Lourenço (pedagogo) e diversos bolsistas de iniciação coentífica e de aperfeiçoamento do CNPq." (LOURENÇO, 1998, p. 33).
} 
aprimoramento da metodologia. A experiência foi tão bem aceita que em 1989 a Comissão de Avaliação Institucional já se transformara em Centro de Avaliação Institucional. Não obstante, a

[...] partir de 1994 observou-se o arrefecimento do entusiasmo para com as propostas avaliativas, fato que coincidiu com a desaceleração do PAIUB como política de avaliação no Brasil e a institucionalização do "Provão", que transformara a concepção formativa de avaliação de outrora em escores e resultados sintéticos, incapazes de traduzir a dimensão global do processo de ensino-aprendizagem. (BEDRITICHUK, 2015, p. 52).

Nesse período, adotou-se no processo avaliativo da UnB o modelo CIPP (ContextoInsumos-Processos e Produtos) e arquivaram-se os resultados da avaliação do ensino, sem qualquer deliberação sobre os cursos de graduação. (LOURENÇO, 1998). A iniciativa de avaliação na Universidade de Brasília teve continuidade e, inclusive, se perpetuou em um modelo que contava com (i) avaliação geral, (ii) avaliação específica da graduação e (iii) pesquisa de egressos. "A metodologia de avaliação institucional da UnB tornou-se uma referência na avaliação institucional de universidades e subsidiou a elaboração de propostas de avaliação em várias universidades brasileiras.” (SOARES NETO, et. al., 2013, p. 3-4). Esta dissertação, portanto, envolveu a Comissão Própria de Avaliação de uma instituição de grande porte e que possui largo histórico de autoavaliação, o que enriqueceu consideravelmente o trabalho.

Sujeitos da pesquisa - A perspectiva dialética adotada nesta pesquisa exigiu que se explorassem diferentes opiniões sobre a prática da autoavaliação. Dessa forma, por meio de entrevistas semiestruturadas, colheram-se posicionamentos tanto em um nível macro, como micro.

Em nível macro se selecionou desde pessoas responsáveis pela implementação da política do Sinaes até às que têm essa como objeto principal de suas pesquisas. Entrevistou-se um membro do Inep e um membro da Conaes, levando em consideração a posição que assumiam nesses respectivos órgãos no período de vigência desta pesquisa. O Inep foi representado por um servidor público alocado na Daes/Inep; e a Conaes por um de seus membros. Entrevistaram-se ainda quatro pesquisadores da temática da avaliação da educação superior brasileira. Esses foram escolhidos entre os membros do subgrupo 3 da Rede de pesquisa UNIVERSITAS/ $\mathrm{Br}^{22}$ (POW1) - sub cujo projeto de pesquisa em vigência tem como

\footnotetext{
${ }^{22}$ A autora desta dissertação é integrante do subgrupo 3 da Rede de pesquisa UNIVERSITAS/Br desde abril de 2014. A página web da rede é < http://www.redeuniversitas.com.br/2015/01/rede-universitas.html>.
} 
objetivo principal compreender a qualidade da educação superior no Brasil em tempos de expansão.

Em nível micro, por sua vez, se entrevistaram quatro membros da Comissão Própria de Avaliação da Universidade de Brasília. Conforme a resolução do Conselho Universitário n. 0031/2013, essa deve ser constituída por um presidente; quatro servidores docentes; quatro servidores técnico-administrativos; dois membros da administração da instituição, sendo um deles o Diretor de Avaliação e Informações Gerenciais, cuja diretoria é vinculada ao Decanato de Planejamento e Orçamento; quatro discentes, sendo dois de graduação e dois de pósgraduação; e dois representantes da sociedade civil organizada. (UnB, 2013). O critério de seleção foi que se respeitasse a representação de um membro para cada segmento exigido pela lei do Sinaes para sua constituição - docente, técnico administrativo, discente e sociedade civil organizada -; e ainda que se levasse em conta o grau de engajamento desses com a temática da avaliação da educação superior e da autoavaliação institucional, especificamente. Para tanto, foi procurado em seus currículos Lattes: (i) tempo em que se encontravam na CPA, (ii) formação relacionada à temática da autoavaliação, e (iii) trabalhos publicados sobre a mesma.

Esses dois níveis de relação com o tema - macro e micro -, formaram, portanto, três grupos distintos de entrevistados: (i) responsáveis pela implementação da política do Sinaes, (ii) pesquisadores da temática da avaliação da educação superior, e (iii) membros da CPA da UnB. Todos eles atuam direta ou indiretamente com os processos de autoavaliação institucional, seja consolidando-os, seja refletindo a seu respeito, sendo que, como defende Dias Sobrinho (2004), “avaliação da educação superior é um dos temas mais complicados e complexos, tanto para quem se dedica à teoria quanto para quem se envolve em sua prática.”. (p. 705).

Ao se defrontar com as diferentes relações que cada um desses sujeitos exerce com a autoavaliação, a pesquisadora se deparou com os fatores distintos que perpassam essa realidade. Por conseguinte, as contradições inerentes ao objeto da pesquisa, as quais não seriam visualizadas se só a CPA tivesse sido levada em conta, por exemplo, ficaram mais visíveis.

Como mostram Politzer; Besse e Caveing (1970), “as descobertas científicas não podem ser realizadas, quando há violação da primeira lei da dialética, isto é, se o fenômeno estudado for isolado das condições que o cercam.”. (p. 39). Seria impossível, portanto, em um trabalho sob essa perspectiva, desconsiderar as categorias anteriormente descritas ou ainda os posicionamentos dos três grupos de sujeitos selecionados. Sob a perspectiva desses atores, se 
entende que a implementação da autoavaliação está condicionada às relações existentes entre ela e o meio ambiente, sendo esse último: (i) os sujeitos e (ii) os acontecimentos históricos nos quais estão inseridos. A realidade, por sua vez, é o todo e não "um amontoado acidental de objetos, de fenômenos destacados uns dos outros, isolados e independentes" (p. 36); daí, a importância de, nesta pesquisa, não se ter levado em consideração somente a visão da Comissão Própria de Avaliação.

Valendo-se de um exemplo simples, os referidos autores demostram como que ações dos mais diversos sujeitos podem contribuir com a mesma causa. Segundo eles, um homem que não exercia cargo político participava da luta pela paz, a seu modo, conversando com companheiros do trabalho e promovendo em seu prédio reuniões sobre o assunto com os locatários. Muitos creram que esse sujeito estava perdendo tempo e trabalho, porém, para a perspectiva dialética não, pois ele não está só.

Naquele mesmo instante, milhões de homens agem como ele, no mesmo sentido, contra as mesmas forças. Há uma conexão universal entre todas essas iniciativas, que são como elos de uma só cadeia. Há uma ação recíproca entre todas essas iniciativas, uma vez que cada um ajuda o outro (reciprocidade) com o exemplo, com a experiência, com os revezes e os êxitos. Quando forem confrontadas as iniciativas ver-se-á que não foram isoladas, ainda que o parecessem: tudo se relaciona. (POLITZER; BESSE; CAVEING, 1970, p. 35).

Da mesma forma, todos os 10 sujeitos auscultados nesta pesquisa, em confronto ou conformação com a historicidade que influencia as políticas de avaliação da educação superior no país, convergem para uma ressignificação da autoavaliação. Entre os entrevistados, 8 (oito) são do sexo feminino e 2 (dois) do sexo masculino e todos tiveram sua identidade preservada ${ }^{23}$. No quadro de número 1 , na sequência, é exposta a codificação utilizada para cada um, bem como dados sobre formação acadêmica e trajetória profissional, o que já é uma primeira demonstração do engajamento deles com o objeto desta pesquisa - a autoavaliação.

\footnotetext{
${ }^{23}$ Para ajudar na garantia da preservação da identidade dos sujeitos auscultados para esta pesquisa, todos foram referenciados ao longo do trabalho usando-se na escrita o gênero masculino ("o entrevistado", "o pesquisador", "o representante", por exemplo).
} 
Quadro 1: Códigos e perfis dos sujeitos da pesquisa

\begin{tabular}{|c|c|c|c|}
\hline Código & Entrevistados & Vínculo institucional & Formação \\
\hline DO & $\begin{array}{l}\text { Representante } \\
\text { do segmento } \\
\text { docente da } \\
\text { CPA da UnB }\end{array}$ & $\begin{array}{ll}\text { Universidade } & \text { de } \\
\text { Brasília - UnB } & \end{array}$ & $\begin{array}{l}\text { Graduação em Economia, mestrado na } \\
\text { mesma área e também em Estatística } \\
\text { Aplicada e doutorado em Economia. }\end{array}$ \\
\hline DI & $\begin{array}{l}\text { Representante } \\
\text { do segmento } \\
\text { discente da } \\
\text { CPA da UnB }\end{array}$ & $\begin{array}{ll}\text { Universidade } & \text { de } \\
\text { Brasília - UnB } & \end{array}$ & $\begin{array}{l}\text { Graduação em Letras, especialização em } \\
\text { Linguística Textual e em Ensino à } \\
\text { Distância, mestrado em Literatura } \\
\text { Brasileira e doutorado em andamento em } \\
\text { Linguística. }\end{array}$ \\
\hline TE & $\begin{array}{l}\text { Representante } \\
\text { do segmento } \\
\text { técnico } \\
\text { administrativo } \\
\text { da CPA da } \\
\text { UnB }\end{array}$ & $\begin{array}{l}\text { Universidade } \\
\text { Brasília - UnB }\end{array}$ & $\begin{array}{l}\text { Graduação em Administração e } \\
\text { especialização em Gestão Estratégica de } \\
\text { Pessoas. }\end{array}$ \\
\hline SO & $\begin{array}{l}\text { Representante } \\
\text { do segmento } \\
\text { sociedade civil } \\
\text { organizada da } \\
\text { CPA da UnB }\end{array}$ & $\begin{array}{l}\text { Secretaria de } \text { Estado } \\
\text { de Educação do } \\
\text { Distrito Federal } \\
\text { SEEDF }\end{array}$ & $\begin{array}{l}\text { Graduação em Letras, mestrado e } \\
\text { doutorado em Educação. }\end{array}$ \\
\hline P1 & $\begin{array}{l}\text { Pesquisador da } \\
\text { área } 1\end{array}$ & $\begin{array}{l}\text { Universidade Federal } \\
\text { de São Carlos - } \\
\text { UFSCar }\end{array}$ & $\begin{array}{l}\text { Graduação em Filosofia, mestrado em } \\
\text { Filosofia e doutorado em Educação. }\end{array}$ \\
\hline P2 & $\begin{array}{l}\text { Pesquisador da } \\
\text { área } 2\end{array}$ & $\begin{array}{l}\text { Universidade de } \text { São } \\
\text { Paulo-USP }\end{array}$ & $\begin{array}{l}\text { Graduação em Letras, mestrado em } \\
\text { Ciências Sociais e doutorado em } \\
\text { Educação. }\end{array}$ \\
\hline P3 & $\begin{array}{l}\text { Pesquisador da } \\
\text { área } 3\end{array}$ & $\begin{array}{l}\text { Universidade Federal } \\
\text { de Minas Gerais - } \\
\text { UFMG }\end{array}$ & $\begin{array}{l}\text { Graduação em Ciências Sociais, mestrado } \\
\text { em Sociologia e em Educação, e } \\
\text { doutorado também nessa última área. }\end{array}$ \\
\hline P4 & $\begin{array}{l}\text { Pesquisador da } \\
\text { área } 4\end{array}$ & $\begin{array}{l}\text { Universidade } \text { Federal } \\
\text { de São Paulo - } \\
\text { UNIFESP }\end{array}$ & $\begin{array}{l}\text { Graduação em Psicologia, especialização } \\
\text { em Avaliação institucional e em } \\
\text { Processos de Mudança na Formação } \\
\text { Superior em Saúde, mestrado e doutorado } \\
\text { em Educação. }\end{array}$ \\
\hline IN & $\begin{array}{l}\text { Representante } \\
\text { da Daes/Inep }\end{array}$ & $\begin{array}{l}\text { Diretoria de Avaliação } \\
\text { da Educação Superior } \\
\text { do Instituto Nacional } \\
\text { de Estudos e Pesquisas } \\
\text { Educacionais Anísio } \\
\text { Teixeira - Daes/Inep }\end{array}$ & $\begin{array}{l}\text { Graduação em Pedagogia, especialização } \\
\text { em Educação, mestrado em Engenharia } \\
\text { de Produção e doutorado em Educação. }\end{array}$ \\
\hline $\mathrm{CO}$ & $\begin{array}{l}\text { Representante } \\
\text { da Conaes }\end{array}$ & $\begin{array}{l}\text { Universidade Federal } \\
\text { de Viçosa - UFV e } \\
\text { Comissão Nacional de } \\
\text { Avaliação } \\
\text { Educação Superior - } \\
\text { Conaes }\end{array}$ & $\begin{array}{l}\text { Graduação em Veterinária, mestrado e } \\
\text { doutorado em Patologia. }\end{array}$ \\
\hline
\end{tabular}

Fonte: elaboração própria. 
O quadro de número 1 retrata o perfil dos sujeitos participantes da pesquisa no que diz respeito a sua formação acadêmica e atuação profissional. Em relação aos representantes da Comissão Própria de Avaliação da Universidade de Brasília, observa-se que a formação acadêmica deles se deu em diferentes áreas do conhecimento, tanto na graduação como na pós-graduação. Nenhum dos representantes possui graduação em Pedagogia e somente um tem mestrado e doutorado em Educação, por exemplo, sendo que esse não possui vínculo empregatício com a universidade da qual é membro da CPA, senão com outro trabalho na área de educação - SEEDF. Todos começaram a fazer parte da Comissão há menos de dois anos, a contar da data de defesa desta dissertação, e, segundo os mesmos, passaram a se inteirarem sobre o processo de autoavaliação institucional sob a configuração do Sinaes durante a própria prática recente.

Juntos a outros treze membros, os entrevistados fazem parte de uma comissão que busca garantir representatividade à sede e aos três campi da instituição - de Ceilândia, Planaltina e Gama. O docente entrevistado faz parte do quadro da Faculdade de Economia, Administração e Contabilidade (FACE), enquanto os demais docentes da CPA são da Engenharia Eletrônica do campi Gama; da Enfermagem do campi Ceilândia; do Instituto de Psicologia; e do Instituto de Letras, localizados na sede. O discente entrevistado faz doutorado na área de Letras e os outros representantes desse segmento são do mestrado em Contabilidade; da graduação em Geologia e da graduação em Direito. O técnico administrativo que representou a CPA nesta pesquisa é do Decanato de Planejamento e Orçamento e os outros são da Faculdade de Ceilândia, da de Planaltina e do Centro de Estudos Avançados de Governo e Administração. Finalmente, o representante da sociedade civil organizada entrevistado é da Secretaria de Estado de Educação do Distrito Federal, enquanto o outro faz parte da Organização de Estados Ibero-Americanos para a Educação, a Ciência e a Cultura. A CPA da UnB conta ainda com representantes da Administração, que fazem parte do Decanato de Planejamento e Orçamento e do Decanato de Ensino de Graduação.

Já os quatro pesquisadores da área de avaliação da educação superior entrevistados têm formação inicial em diferentes áreas, sendo que somente um em Pedagogia. Quanto à pós-graduação, no entanto, todos têm mestrado e/ou doutorado na área de Educação. Nenhum trabalha na mesma instituição de educação superior, não obstante, todos fazem parte de universidades públicas e localizadas na região sudeste, sendo três do Estado de São Paulo (duas na capital, São Paulo, e uma em São Carlos) e uma do Estado de Minas Gerais (em Belo Horizonte). Apenas o pesquisador da Unifesp, segundo o mesmo, baseou seus comentários 
em pesquisa própria referente a relatórios de autoavaliação. Os demais informaram que já leram a respeito da autoavaliação institucional, vivenciam o processo em suas instituições e conhecem os seus fundamentos, mas nunca a tomaram como objeto de pesquisa até o momento.

Por fim, os representantes das instâncias responsáveis por implementar a política do Sinaes - Instituto Nacional de Estudos e Pesquisas Educacionais Anísio Teixeira e Comissão Nacional de Avaliação da Educação Superior -, possuem formação bastante distinta, desde a graduação até a pós graduação. O representante da Daes/Inep tem graduação em Pedagogia, especialização e doutorado na área de Educação e mestrado na Engenharia; já o da Conaes tem graduação em Veterinária e mestrado e doutorado em Patologia. Ambos, independentemente da formação, discutem a autoavaliação com periodicidade constante junto a seus pares, na Daes/Inep e na Conaes.

Tem-se, portanto, três grupos de entrevistados nesta pesquisa: (i) membros da Comissão Própria de Avaliação da Universidade de Brasília; (ii) pesquisadores da área de avaliação da educação superior; e (iii) responsáveis pela implementação do Sinaes. Todos foram entrevistados no próprio ambiente de trabalho em data e horário previamente acordado via e-mail e o tipo de entrevista adotada foi a semiestruturada. Nessa, combinam-se perguntas abertas e fechadas e o informante tem a possibilidade de discorrer sobre o tema em uma espécie de conversa informal, a qual o dá mais liberdade para se expressar. (BONI; QUARESMA, 2005).

Após a realização das entrevistas e a respectiva transcrição delas, os dados foram triangulados, o que significa dizer que as falas dos entrevistados foram relacionadas e contrastadas entre si, bem como à literatura especializada da área e aos documentos analisados, anteriormente citados. O objetivo disso é tanto a abertura à possibilidade de emersão de novas ou mais aprofundadas dimensões que envolvam o objeto, como o exame do fenômeno a partir do olhar de múltiplas perspectivas. (AZEVEDO, et, al. 2013). Na ilustração de número dois, a seguir, percebe-se o confronto principal de informações que propicia a triangulação e o caminho percorrido para chegar a tal. 
Ilustração 2: Triangulação de dados da pesquisa

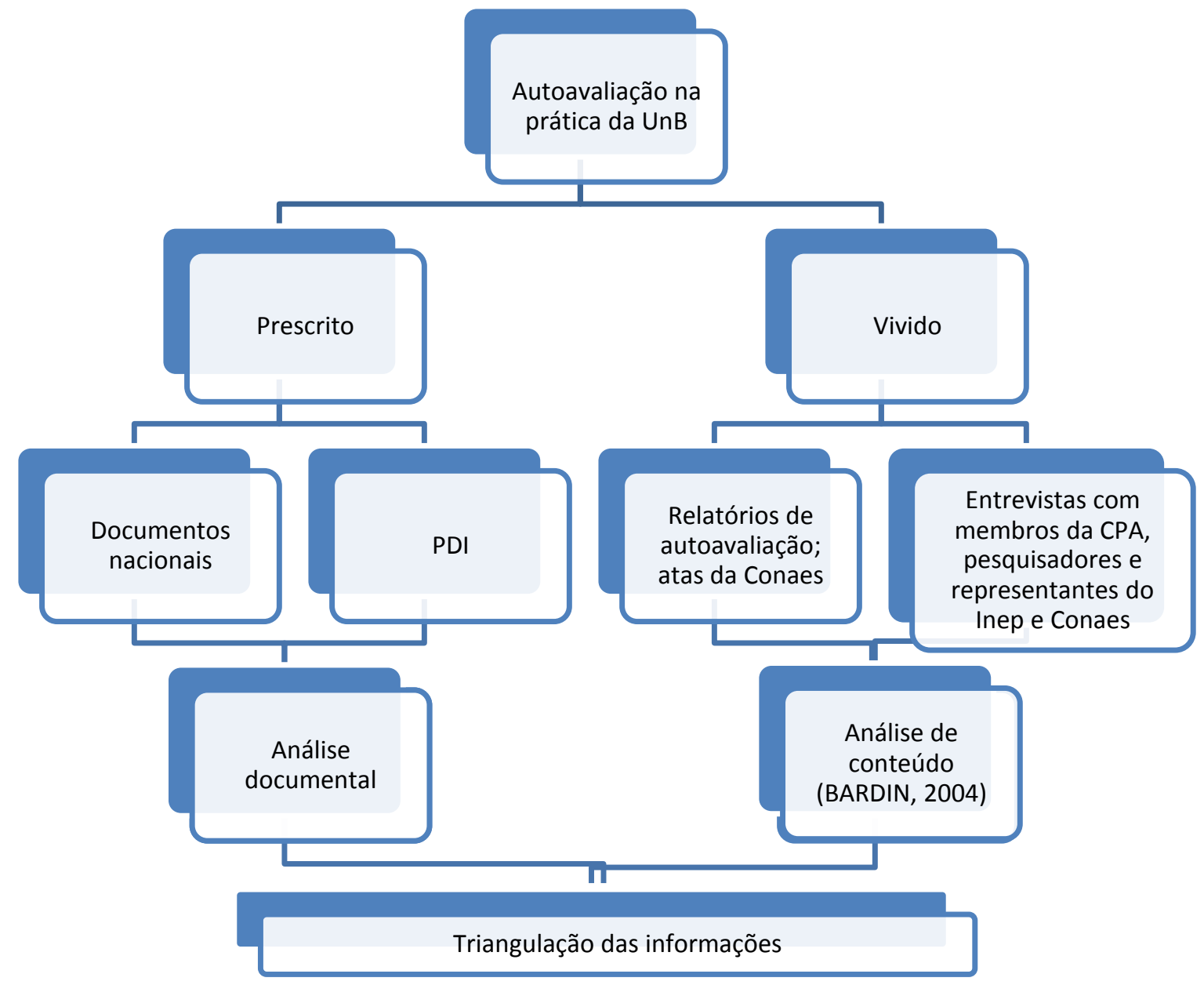

Fonte: Elaboração própria.

Todas as percepções aludidas na ilustração 2 no que tange ao vivenciado na prática da autoavaliação passaram por um processo de descrição objetiva, sistemática e quantitativa do conteúdo com base em Bardin (2004). A partir da perspectiva dessa autora, as entrevistas foram analisadas a fim de se identificar os temas - ou unidades de significação -, que naturalmente emergiam das falas dos sujeitos, o que será explicado detalhadamente no capítulo três. Observa-se ainda ser nesse capítulo que se concentra a discussão envolvendo as falas dos interlocutores, contudo, em consonância à perspectiva dialética, as vozes não foram isoladas nesta parte do trabalho, aparecendo, do contrário, transversalmente em todo o percurso da pesquisa. É que, como indica Politzer; Besse e Caveing (1970, p. 37), a dialética "considera que nenhum fenômeno da natureza pode ser compreendido, quando encarado isoladamente, fora dos fenômenos circundantes", o que, na visão da autora desta pesquisa, inclui a maneira como se conectam as falas às teorias durante a escrita. 
Considerando o exposto, a dissertação encontra-se organizada contemplando a seguinte estrutura: considerações iniciais, considerações finais e três capítulos. O primeiro capítulo, "Avaliação da educação superior e o desafio de fomentar a qualidade: concepções divergentes em debate", foi estruturado de tal modo a perscrutar a relação que (i) a finalidade dos segmentos acadêmico-administrativos de IES que vêm expandindo mais e (ii) o tipo de avaliação priorizado pelo Estado capitalista brasileiro têm com a qualidade da educação superior. Na sequência, pontuam-se as principais tentativas de conceituação da qualidade no contexto em questão. Tal caminho - composto por três partes - subsidiou a contextualização do desafio recaído sob o Sinaes e especificamente sob a autoavaliação - fomentar qualidade -, visto que são apreciadas as forças contrárias que influenciam a implementação dessa política, bem como a polissemia que envolve o termo qualidade.

O segundo capítulo, "Políticas de avaliação da educação superior brasileira: as idas e vindas das avaliações formativa e controladora" se divide em duas partes. A primeira retoma as políticas avaliativas de educação superior do Estado brasileiro das décadas de 1980 e 1990, até imediatamente antes da institucionalização do Sinaes. A segunda parte, por sua vez, esmiúça o Sinaes, originado no governo de Luís Inácio Lula da Silva e em continuidade no governo de Dilma Rousseff. Nessa última parte percorre-se a proposta de quando da origem do sistema avaliativo e as reformulações e mudanças no seu percurso. Com isso, foram expostos tanto os retornos que o Sinaes faz a aspectos de avaliações anteriores, como a fidelidade da política à sua proposta formativa.

O terceiro capítulo, “Autoavaliação na Universidade de Brasília: entraves e possíveis avanços", traz a interpretação e análise dos dados colhidos por meio dos documentos oficiais e das entrevistas realizadas. Dessa forma, foi dividido em três partes, em consonância aos dados coletados e aos objetivos específicos da pesquisa. A primeira detalha o que já foi apresentado brevemente nestas considerações iniciais sobre aspectos metodológicos e sujeitos. A segunda versa sobre as dificuldades do momento de preparação da autoavaliação. E a terceira traz o processo autoavaliativo, seus resultados e problemáticas identificadas.

As categorias metodológicas e de conteúdo elencadas para o estudo aparecem transversalmente em todos os capítulos. Esses, juntamente com esta parte e com as considerações finais, compõem o que se espera ser uma pesquisa relevante à área. Os trabalhos de pós-graduação com foco na autoavaliação, segundo um dos pesquisadores entrevistados, podem - se bem lidos -, atuar como indicadores ou elementos a serem considerados no momento da avaliação e contribuir, "para aprimorar a autoavaliação e rever a importância que ela atualmente tem.”. (P2, informação verbal). 


\section{CAPÍtulo 1: AVALIAÇÃO DA EDUCAÇÃO SUPERIOR E O DESAFIO DE FOMENTAR A QUALIDADE: CONCEPÇÕES DIVERGENTES EM DEBATE}

\subsection{INTRODUÇÃO}

Uma política de avaliação da educação superior não pode, como mostram Oliveira; Fonseca e Amaral (2006), encerrar-se na divulgação dos resultados. Ao contrário, deve oferecer subsídios à tomada de decisões na perspectiva da qualidade, levando em conta a reflexão coletiva das informações coletadas no processo avaliativo. A autoavaliação institucional na perspectiva do Sinaes foi projetada com essa finalidade, mas por vários motivos pode estar sofrendo dificuldades no percurso e não atingindo seu fim.

No contexto do Sinaes, a autoavaliação surge como instrumento capaz de gerar um olhar reflexivo da IES sobre si mesma, revelando as potencialidades e fragilidades dessa e, por conseguinte, impulsionando tomadas de decisões em prol da qualidade. No entanto, a autoavaliação, tal como vem geralmente sendo conduzida, não ganha a amplitude e importância previstas. Ademais, mesmo quando segue as diretrizes da política, nem sempre é capaz de gerar mudanças na gestão da IES, por exemplo, (BRASIL/INEP, 2011), podendo converter-se, por conseguinte, apenas em um instrumento de controle do sistema. Ao que tudo indica, como mostram Cardoso e Dias Sobrinho (2014),

[...] a concepção proposta pelo SINAES encontra-se ameaçada por operações cotidianas de fiscalização e controle utilizadas pelo Estado distantes do que se propôs como avaliação e com o objetivo primordial de se estabelecerem rankings, configurando uma atitude voltada para a competitividade, e não para a solidariedade; uma ação voltada para o mercado, e não para a sociedade. (p. 272).

Desse modo, ignorar a relação Estado/educação superior, no que tange à política avaliativa cuja finalidade declarada é a qualidade, seria um erro para uma pesquisa que pretendeu explorar a autoavaliação institucional. Afinal, por que o Estado, com o advento da criação do Sinaes, declara que fomentará e verificará a qualidade da educação superior a partir da integração de três elementos avaliativos, sendo que na prática isso parece não acontecer?

Como mostra um dos pesquisadores da área entrevistados em virtude desta pesquisa, o processo de autoavaliação "não pode excluir outros, eu diria, outros resultados da avaliação, 
que compõem todo o processo da avaliação da educação superior no Brasil, em se falando de avaliação institucional" (P4, informação verbal). Em contrapartida, tampouco o Enade ou a avaliação de cursos devem funcionar de forma estanque. $O$ grande desafio para a avaliação da educação superior, segundo Dias Sobrinho (2010), é exatamente "encontrar o ponto de equilíbrio entre a avaliação formativa e a regulação controladora.” (p. 223). Nesse equilíbrio encontra-se a manutenção do Sinaes como sistema integrado e capaz de fomentar a qualidade que propõe. Trabalhar para alcançá-lo só não seria visto como algo importante se, em verdade, a concepção de qualidade do Sinaes contradisser os princípios de qualidade que o Estado almeja, por exemplo.

As políticas públicas, entre as quais as de educação, "são influenciadas tanto no processo de formulação quanto no de implementação, pelas forças antagônicas do poder que impera num determinado contexto histórico do modelo de produção capitalista.”. (RODRIGUES, 2015, p. 64). Se a finalidade declarada do Sinaes é a qualidade educacional, mas essa parece não estar sendo fomentada via interação de todos seus componentes e valorização da avaliação institucional, faz-se necessário problematizar as concepções de qualidade que rondam a educação superior. Conhecê-las é perscrutar possíveis influências que levam à subsunção da autoavaliação no processo de implementação do sistema.

Ressalta-se, contudo, que conforme Dourado (2002), as alterações provocadas pelas políticas educacionais, entre as quais as de avaliação, no Brasil "não podem ser compreendidas sem o entendimento das contingências históricas e econômicas que balizam o cenário atual das transformações societárias do mundo atual.”. (p. 245). Por conseguinte, todos os tópicos deste capítulo seguirão um movimento de aproximação e distanciamento aos fatos do passado que, relacionados à economia do país, podem estar influenciando a implementação do Sinaes.

Conforme citado nas considerações iniciais desta pesquisa, quando as fragilidades econômicas resultantes da crise mundial instaurada na década de 1970 bateram à porta tanto das economias mais fracas como das mais fortes se instaurou uma profunda recessão. Essa,

[...] exacerbada pelo choque do petróleo, evidentemente retirou o mundo capitalista do sufocante torpor da "estagflação" (estagnação da produção de bens e alta inflação dos preços) e pôs em movimento um conjunto de processos que solaparam o compromisso fordista. (HARVEY, 1992, p. 140).

Consequentemente, a ideologia neoliberal despontou estimulando a reestruturação dos Estados nacionais para que o mundo, capitalista, voltasse a se desenvolver, mas agora sem 
assistir a população como deveria. Nesse contexto, os países foram estimulados até mesmo por organismos internacionais a, entre outras questões: (i) impulsionarem a autonomia dos mercados, inclusive os educacionais, e a (ii) implantarem avaliações com foco nos resultados, tendo sempre como meta o desenvolvimento econômico. Tal estímulo, quando acatado, como o foi no Brasil, configura uma postura estatal subordinada ao capital, o que não pode ser ignorado. As políticas educacionais brasileiras, nesse contexto, vêm sendo balizadas por essa configuração de Estado sugerida ou imposta às sociedades. Consequentemente, qualquer política, e especificamente a avaliativa, tem como fator limitador a meta no desenvolvimento econômico, já que, esse, em uma sociedade capitalista, deve ser sempre preservado e reforçado pelos governos.

Obviamente, espera-se que todo país saiba filtrar as sugestões e imposições que recebe; e que logre, assim, imprimir as marcas de seu povo em suas políticas. Segundo Dourado (2002), no entanto, é particularmente notável a condição do Brasil como parceiro e fiel depositário, por exemplo, das prescrições internacionais. Recomendações como as do Banco Mundial para a educação superior - em que as políticas educacionais deveriam acompanhar a lógica do campo econômico - estariam, sim, presentes no contexto brasileiro.

Dessa forma, para se discutir o desafio que o Sinaes e, especificamente, a autoavaliação tem, qual seja fomentar a qualidade educacional diante de posicionamentos contrastantes sobre o tema, este capítulo divide-se em três partes. Aqui se articulará, dialeticamente, a qualidade à finalidade da educação superior, levando em conta a expansão do setor, no tópico 1.2; bem como à finalidade da avaliação da educação superior, no 1.3; trazendo ainda os conceitos de qualidade a partir da ótica dos organismos internacionais e da literatura especializada da área, no item 1.4.

\subsection{INSTITUIÇÕES DE EDUCAÇÃO SUPERIOR PRIORIZADAS EM TEMPOS DE EXPANSÃO: AS DIVERSAS FINALIDADES EDUCACIONAIS}

Uma das questões centrais da política educacional brasileira é ampliar o acesso à educação superior. No entanto, como mostram Fávero e Sguissardi (2012), para que a relação quantidade/qualidade ocorra efetivamente seria preciso, antes, estabelecer os tipos e modelos de instituições de educação superior que se quer ter; para, em seguida, definir como as IES 
devem ser ampliadas ou multiplicadas. Assim, é possível se perguntar que tipo de instituição de educação superior o Estado capitalista brasileiro almeja e que fim teriam essas instituições.

Essa discussão relaciona-se ao objeto deste trabalho - a autoavaliação - à medida que dependendo da finalidade da IES, a projeção dessa para a própria qualidade muda, interferindo, portanto, nas metas e alcances da autoavaliação. Se considerar-se, por exemplo, que a prática autoavaliativa está inserida em uma política de avaliação que deveria condescender-se ao que o Estado coloca como finalidade para a educação superior, essa prática, talvez, nem precisava ter sido implantada no contexto do Sinaes, por exemplo. Afinal, o que é a autoavaliação senão o processo de empoderar toda uma comunidade acadêmica a fim de que sejam reflexivos, críticos, inovadores e instintivos? O que acontece se a comunidade perceber, de forma crítica, inovadora e instintiva, que o que lhes foi oferecido como educação superior é muito pouco?

As Comissões Próprias de Avaliação, se escutarem os docentes, poderão dar-se conta, por exemplo, de que alguns querem que a IES tenha uma estrutura física para aulas dinâmicas, materiais para promover a reflexão dos estudantes, excursões para mostrarem a teoria na prática e que a eles sejam pagos salários compatíveis aos seus esforços e vontades, por exemplo. E se escutarem os discentes deverão perceber que esses podem esperar muito mais que um diploma que diga que eles sabem fazer determinada tarefa. Esses podem preferir "saber fazer" com consciência e criticidade.

Em suma, a CPA estaria sujeita a revelar uma instituição de educação superior que talvez não exista e que o Estado parece mesmo não querer que se desenvolva. E se realmente, tal como se prevê, as conclusões da autoavaliação subsidiarem mudanças em prol da qualidade das IES, se poderá até presenciar instituições caminhando na direção contrária à da lógica capitalista adotada pelo Estado.

Tomando, assim, como exemplo a autoavaliação institucional, percebe-se que há uma contradição entre a finalidade da avaliação da educação superior brasileira e a finalidade da educação superior, propriamente dita. O Sinaes visa assegurar e fomentar a qualidade educacional, mas o Estado brasileiro propiciou a criação de instituições que têm como foco a qualidade? Ou de IES que se preocupam com uma formação ampla do estudante? A preocupação principal do Estado e, logo, de muitas IES não seria o lucro? O Estado quer mesmo empoderar as instituições para que essas sejam coparticipantes da avaliação? Longe de se ter resposta para tantas dúvidas, considera-se, contudo, que a questão da finalidade das instituições da educação superior brasileira é realmente uma discussão antiga, mas que continua pulsante na atualidade. 
Embora não haja uma única interpretação para o que seria a concepção ideal de instituição de educação superior, com suas finalidades e funções, o pensador Anísio Teixeira ${ }^{24}$ foi pioneiro nesse assunto, não podendo deixar de ser aqui referenciado. Desde os anos 1930, o autor problematiza a distinção da universidade dos outros tipos de instituições, bem como idealiza o tipo de universidade que se deveria estabelecer. Em discurso proferido no dia 31 de julho de 1935 na solenidade de inauguração dos cursos da recém-criada Universidade do Distrito Federal (UDF), o autor diz que a função da universidade é

[...] única e exclusiva. Não se trata somente de difundir conhecimentos. $\mathrm{O}$ livro também os difunde. Não se trata, somente, de conservar a experiência humana. O livro também a conserva. Não se trata, somente, de preparar práticos ou profissionais, de ofícios ou artes. A aprendizagem direta os prepara, ou em último caso, escolas muito mais singelas do que as universidades.

Trata-se de manter uma atmosfera de saber para se preparar o homem que o serve e o desenvolve. Trata-se de formular intelectualmente a experiência humana, sempre renovada, para que a mesma se torne consciente e progressiva. (TEIXEIRA, 2010, p. 33).

Observa-se que a universidade, para o pensador, teria uma função muito mais ampla do que transmitir conhecimento e preparar profissionais para determinadas funções exigidas pelo mercado de trabalho. Ela deveria formar seres humanos críticos.

Complementarmente, em 1968, Anísio Teixeira volta a refletir sobre esse assunto e define aquelas que deveriam ser as quatro funções fundamentais das universidades brasileiras. A primeira refere-se à formação profissional, sob a qual as universidades,

[...] salvo algumas exceções, têm como objetivo preparar profissionais para as carreiras de base intelectual, científica e técnica. [...]

\footnotetext{
${ }^{24}$ Anísio Teixeira (1900-1971), apesar de não ter podido discutir a universidade contemporânea, é um pensador atemporal. Segundo Nunes (2010, p. 10), “o seu devotamento incondicional à democracia e à educação para a democracia, traduzido em livros, artigos, relatórios, cartas e, sobretudo, em uma excepcional obra de administração pública, ainda se manifesta à frente do nosso tempo.”. Foi inspetor Geral de Ensino do Estado da Bahia - seu primeiro cargo público, em 1924 -; em seguida, docente da Escola Normal de Salvador, onde lecionou Filosofia e História da Educação; diretor da Instrução Pública do Distrito Federal no Rio de Janeiro; tornou-se um dos signatários do Manifesto dos Pioneiros da Educação Nova (1932), o qual propunha diretrizes para a reconstrução educacional do país; assumiu por um tempo a Secretaria Geral da Campanha de Aperfeiçoamento de Pessoal de Nível Superior (Capes) e, posteriormente, a diretoria do Inep. Durante a gestão nesses dois órgãos, participou ativamente da discussão da Lei de Diretrizes e Bases da Educação Nacional (1961), proferiu várias palestras e escreveu livros. Em 1961, foi um dos principais idealizadores da Universidade de Brasília, assumindo sua reitoria em 1962, onde permaneceu até a instauração do governo militar, em 1964, o qual o afastou do cargo. Em virtude disso, foi lecionar, na condição de professor visitante, em universidades dos Estados Unidos, retornando ao Brasil quando acabou a ditadura. Ao regressar, tornou-se consultor da Fundação Getúlio Vargas e permaneceu integrando o Conselho Federal de Educação, entre muitos outros feitos. (NUNES, 2010). Anísio Teixeira deu, pois, contribuições sem precedentes à educação brasileira; e seus feitos naturalmente reverberam para além do seu tempo.
} 
Não é fácil de caracterizar a segunda grande função. Seria a do alargamento da mente humana, que o contato com o saber e a sua busca produzem nos que frequentam a universidade. É algo mais que cultura geral. É a iniciação do estudante na vida intelectual, o prolongamento de sua visão, o ampliar-se de sua imaginação, obtidos pela sua associação com a mais apaixonante atividade humana: a busca do saber. [...]

A terceira função é a de desenvolver o saber humano. A universidade não só cultiva o saber e o transmite, como pesquisa, descobre e aumenta o conhecimento humano. Esse objetivo não é o mesmo daquele alargamento mental da inteligência. A universidade faz-se centro de elaboração do próprio saber, de busca desinteressada do conhecimento, de ciência e saber fundamental básico.

Por último, mas não menos importante, a universidade é a transmissora de uma cultura comum. Nisto é que a universidade brasileira mais falhou. Além de profissional, a universidade brasileira, relativamente desinteressada pelo Brasil, não logrou constituir-se transmissora de uma cultura nacional. (TEIXEIRA, 2010, p. 170-171).

Segundo esses princípios, a universidade deveria ser um centro de saber destinado a: (i) preparar profissionais para as áreas intelectual, científica ou técnica; (ii) ampliar a visão de mundo do estudante, instigando-o a sempre buscar o saber; (iii) desenvolver esse saber humano mediante a pesquisa ou busca desinteressada pelo conhecimento; e (iv) transmitir uma cultura nacional.

Transferindo esses quatro tópicos ao contexto de educação do século XXI, percebe-se o quanto essa discussão é atual. Afinal, o que é melhor: formar-se em um contexto como o almejado por Anísio Teixeira ou em um que somente lhe apresente as ferramentas básicas para exercer determinada profissão?

Com base no pensador, tem-se que a universidade deveria ser uma instituição que não estivesse empenhada em formar um profissional para o mercado de trabalho, mas um cidadão consciente e crítico, detentor de habilidades. Não um homem que se adequa ao meio, mas um inconformado que reflete e que se impõe. Não uma pessoa focada na resolução de problemas específicos, mas um ser humano capaz de, coletivamente, pensar nos problemas de cunho social, econômico ou cultural. O mercado de trabalho pode até almejar um profissional que detenha determinada habilidade específica, por exemplo, mas o estudante poderia adquiri-la na universidade sem ser impedido de tantas outras reflexões que o formam como cidadão.

O processo de expansão da educação superior brasileira nas últimas três décadas revela, no entanto, que esse tipo de instituição completa e não reducionista não está sendo priorizada pelo Estado. De fato, como questiona Sguissardi (2008, p. 1015), diante da 
cada um dos meios de produção envolvidos nesta "indústria de ensino", que lugar podem ter no "projeto político-pedagógico" das IES particulares ou privado/mercantis a segunda, terceira e quarta das funções universitárias anunciadas e defendidas por Anísio Teixeira? E mesmo a primeira delas - a da formação profissional - não será, na ausência das demais que lhe dariam consistência e qualidade, a de uma formação empobrecida, possível fruto da sociabilidade produtiva, estreita e neopragmática, eficiente, mas alienada, que interessa aos objetivos do mercado e eventualmente também aos de um Estado semiprivatizado?

Sguissardi (2008) acaba por indicar que o foco primeiro do Estado capitalista é o desenvolvimento econômico a baixo custo, chegando a denominá-lo como "Estado semiprivatizado". Para lográ-lo, esse último necessita de mão de obra e não necessariamente de sujeitos reflexivos, críticos etc. O conhecimento, nessa configuração estatal, pode ser direcionado; não precisa ser amplo. Trigueiro Mendes já anunciava, em 1968, que

[...] a expansão do ensino superior é um empreendimento, e não uma festa. Alguns a querem, dispostos a lutar por ela; muitos a querem, mas não a empreendem, limitando-se ao registro no cartório e ao ritual das inaugurações. Não pretendem, os primeiros impor o ritmo lento em lugar do acelerado que o desenvolvimento reclama; mas o ritmo que desejam é denso, apesar de rápido, enquanto o outro só depressa é constituído. (1968, p. 26).

Percebe-se, nessa passagem, que o autor, na década de 1960, já anunciava a dicotomia presente na finalidade a que se dispõem as IES brasileiras. Para ele, há dois tipos de empreendedores educacionais. Aqueles que acreditam na educação superior, a defendem, e cedem ao ritmo acelerado que o mercado exige, mas o fazem proporcionando um ensino denso; e aqueles que são empreendedores só nos rituais de marketing das inaugurações, por exemplo, e que se preocupam com uma formação rápida, mas não densa. (TRIGUEIRO MENDES, 1968). A questão mercadológica encontra-se presente em ambas, mas a postura de cada IES é diferente, o que é perceptível também nos anos 2000.

O mercado influencia todas as IES, afinal é ele que vai empregar os egressos dessas, no entanto, as instituições diferenciam-se umas das outras basicamente em dois tipos. Ou se rendem ao mercado, colocando-o como sua única finalidade; ou fazem do mercado só mais um dos vários logros que os estudantes alcançarão ao passar pela graduação. A primeira seria uma instituição limitada, enquanto a segunda seria ampla e se aproximaria mais do ideal preludiado por Anísio Teixeira.

Lamentavelmente, tudo indica que a limitação é mais abundante no contexto brasileiro. Sousa (2004) explicitou o marketing produzido e as imagens projetadas pela 
comunidade acadêmica de todas as IES privadas do Distrito Federal criadas entre 1962 e 2001. Para tanto, realizou entrevistas semiestruturadas com os fundadores ou dirigentes e analisou folders, outdoors e propagandas referentes às IES. Como o autor chama atenção, o marketing realizado funciona tanto para intensificar a concorrência entre as instituições do $\mathrm{DF}$, como para agregar os valores e imagens que essas desejam projetar para a comunidade. Do total de IES da região em 2003, 29 instituições - o que correspondia a 74\% -, demonstraram que a imagem que queriam passar ao público é a de que são preocupadas com a qualidade do ensino que ofertam. Enquanto isso, $21 \%$ das IES querem veicular a imagem de instituições voltadas para atender ao aluno em sua integralidade. Curiosamente, destacando as falas e textos publicitários levantados pelo autor, vê-se que o que as instituições consideram como qualidade é formar o aluno para o mercado de trabalho. Enquanto em uma instituição o slogan era "formar e humanizar", em outra,

[...] um dos seus outdoors associava a imagem de um botijão de gás e dizia que quem nela estuda teria gás de sobra para invadir o mercado [...]. Outra optou por uma mensagem indicando um pára-quedista e a pergunta você vai entrar no mercado de trabalho assim? [...]; enquanto uma terceira utilizou uma fotografia de vários peixes de cor preta em um aquário e apenas um bastante colorido, apontando a mensagem destaque-se no mercado (SOUSA, 2004, p. 13-14, grifo do autor).

Muitos podem ler esses exemplos destacados da pesquisa de Sousa (2004) sem nenhuma surpresa ou admiração, até porque é natural que não só no DF, mas em todo o país a população se depare com marketings voltados mesmo ao mercado de trabalho. Porém, a própria falta de estranheza a isso já é um indicativo de que na prática o que se implementou no país, em termos quantitativos, foi instituições que se reduzem, pontualmente, à finalidade mercadológica. Como se verá, a própria legislação já dava base a isso.

O processo de expansão da educação superior brasileira, apoiado nas legislações da área, indica que o Estado priorizou historicamente o lucro. $\mathrm{Na}$ área jurídico-institucional, destacam-se a Constituição Federal, a Lei de Diretrizes e Bases da Educação Nacional e o primeiro e segundo Plano Nacional de Educação, pois esses ditaram/ditam o rumo da expansão.

Como se sabe, legalmente, o Estado brasileiro não tem obrigação para com a promoção do acesso à educação superior pública gratuita. No artigo 205 da CF de 1988 diz-se que a "educação é direito de todos e dever do Estado e da família e que será promovida e incentivada com a colaboração da sociedade" (BRASIL, 1988, art. 205), do que se infere uma 
obrigatoriedade do Estado como provedor de educação. Contudo, logo no artigo 208 da CF, o qual versa sobre o dever do Estado com a educação, diz-se que esse deve garantir o "acesso aos níveis mais elevados do ensino, da pesquisa e da criação artística [educação superior], segundo a capacidade de cada um”, do que se infere, desta vez, que a obrigatoriedade do Estado com o acesso à educação superior seria somente indireta, sendo o mérito de cada um o fator verdadeiramente determinante.

Uma vez que o Estado brasileiro não tem que garantir a oferta de educação superior pública gratuita, tinha, no entanto, que estabelecer as condições a serem atendidas pela iniciativa privada para a oferta desse nível educacional. Assim, no artigo 209, incisos I e II, promulga-se que "o ensino é livre à iniciativa privada, atendidas as seguintes condições: I cumprimento das normas gerais da educação nacional; II - autorização e avaliação de qualidade pelo poder público.” (BRASIL, 1988, art. 209). Observa-se, assim, que, como era de se esperar de um Estado capitalista, o direito social à educação não fica a cargo dos governos, mas a educação deve ser regulada por esses com o auxílio de avaliações. Sobre que tipo de avaliações seriam essas - se formativas ou controladoras - não é falado na Constituição, mas é o tema principal do tópico seguinte, o qual discute dialeticamente finalidade da avaliação e qualidade.

Sob a égide da CF de 1988, foi promulgada, por sua vez, em 1996, a Lei de Diretrizes e Bases da Educação Nacional - Lei 9.394/1996 (BRASIL, 1996) - entendida como lei complementar, que regulamenta as diretrizes bases para a educação nacional. O Caput do Art. $2^{\circ}$ dessa Lei diz que a "educação, dever da família e do Estado, inspirada nos princípios de liberdade e nos ideais de solidariedade humana, tem por finalidade o pleno desenvolvimento do educando, seu preparo para o exercício da cidadania e sua qualificação para o trabalho.” (BRASIL, 1996). Nesse artigo, além de chamar atenção o fato de uma das finalidades da educação ser a qualificação para o trabalho, o que vem bem a calhar em um modelo capitalista de Estado, percebe-se aqui uma sutil diferença em relação ao trecho da CF que diz: "A educação, direito de todos e dever do Estado e da família” (BRASIL, 1988, art. 205).

Ao antepor a família ao Estado na ordem das instituições que têm o dever de proporcionar a educação ao povo brasileiro, a LDB sinaliza que, em algum momento ou em alguma dimensão, a responsabilidade privada seria preferida em relação à responsabilidade pública. (GIOLO, 2009, p. 3).

Isso significa que na $\mathrm{LDBEN}$, mais do que na $\mathrm{CF}$, mas, claro, sob o aval dessa última, o afastamento do Estado enquanto provedor encontra-se mais marcado. Por exemplo, além de 
fazer a anteposição, essa lei "criou os centros universitários e os cursos sequenciais, permitiu substituir o vestibular por outros processos seletivos, flexibilizou os currículos e criou os cursos de tecnologia" (SÉCCA; LEAL, 2009 p. 114). Essas ações, ainda que muito importantes para a garantia da expansão da educação superior e da equidade no acesso a esse nível educacional, carregam o contraponto de terem representado uma facilitação sem precedentes à iniciativa privada acompanhada de uma enorme diferenciação das funções sociais das IES. Como mostram Coleta e Coleta (2007),

[...] o fato de uma IES ser categorizada como universidade, centro universitário ou faculdade isolada, implica apresentar um padrão de cultura organizacional, de valores, de práticas acadêmico-administrativas, típico do grupo a que pertence, ainda que diferenças importantes entre instituições do mesmo grupo possam ser identificadas. (p. 235-236).

As universidades, por exemplo, se caracterizam pela autonomia para criar, organizar e até extinguir cursos, mas também pela indissociabilidade das atividades de ensino pesquisa e extensão. Já os centros universitários têm a autonomia, mas não precisam necessariamente promover a tríade ensino-pesquisa-extensão. O credenciamento como universidade ou centro universitário depende da constatação de padrão satisfatório de qualidade (BRASIL, 2006). No entanto, pode-se dizer que, ao diferenciar as exigências para cada tipo de IES, o Estado relativiza a qualidade, visto que exige menos de centros universitários e de faculdades do que de universidades.

Graças à Lei de Diretrizes e Bases da Educação Nacional recaíram apenas às Universidades várias prerrogativas que aos institutos federais, centros universitários, ou às faculdades não recaem, o que tornou esses dois últimos mais atrativos à iniciativa privada. Em virtude dessa lei, somente as universidades passam, por exemplo, a ser consideradas

[...] instituições pluridisciplinares de formação dos quadros profissionais de nível superior, de pesquisa e de extensão e de domínio e cultivo do saber humano que se caracterizam por:

I - produção intelectual institucionalizada mediante o estudo sistemático dos temas e problemas mais relevantes tanto do ponto de vista científico e cultural, quanto regional e nacional;

II - um terço (1/3) do corpo docente, pelo menos, com titulação acadêmica de mestrado e doutorado;

III - um terço (1/3) do corpo docente em regime de tempo integral (BRASIL, 1996, art. 52). 
Reflexo, talvez, disso, tem-se que a universidade é objeto de interesse tanto do setor público como da iniciativa privada ${ }^{25}$, enquanto os centros universitários e as faculdades são praticamente todos privados ${ }^{26}$. As universidades representam, segundo o censo da educação superior referente ao ano de 2014, 8,2\% das IES do Brasil e 53,2\% das matrículas nos cursos de graduação. Enquanto isso, 1,7\% das IES são Institutos Federais (IF) e Centros Federais de Educação Tecnológica (Cefet) - ambos do setor público -, que comportam 1,7\% das matrículas; 6,2\% são centros universitários que participam com 16,5\% das matrículas; e $83,9 \%$ são faculdades, as quais são responsáveis por $28,6 \%$ das matrículas, sendo que esses dois últimos são representados quase que totalmente pela iniciativa privada. (INEP, 2015).

Sendo assim, às universidades, representadas pelo setor público e privado, recaíam-se várias exigências, enquanto aos centros universitários e faculdades não. Desse modo, o Estado tanto subsidia a diferenciação entre as instituições, como proporciona ao capital a opção de expandir-se por meio da criação de IES das quais se espera menos e cuja criação e manutenção, por conseguinte, é mais barata - centros universitários e faculdades. Por que a todos os tipos de instituição não é exigido o mesmo? Por que só às IES que comportam 53,2\% dos estudantes matriculados no país se exigi que a esses seja proporcionado, por exemplo, 1/3 do corpo docente em regime integral e com formação mínima de mestrado ou doutorado? Por que aos outras $46,8 \%$ de matriculados é suficiente proporcionar-lhes menos?

Todas as IES, é claro, tem que participar das avaliações com vistas à qualidade; o artigo $9^{\circ}$ da LDBEN, por exemplo, explicita a finalidade das políticas avaliativas no sistema educacional brasileiro e as atribuições da União:

[...] V - coletar, analisar e disseminar informações sobre a educação; VI - assegurar processo nacional de avaliação do rendimento escolar no ensino fundamental, médio e superior, em colaboração com os sistemas de ensino, objetivando a definição de prioridades e a melhoria da qualidade do ensino;

VIII - assegurar processo nacional de avaliação das instituições de educação superior, com a cooperação dos sistemas que tiverem responsabilidade sobre este nível de ensino;

IX - autorizar, reconhecer, credenciar, supervisionar e avaliar, respectivamente, os cursos das instituições de educação superior e os estabelecimentos do seu sistema de ensino (BRASIL, 1996).

\footnotetext{
${ }^{25}$ Do total de universidades, 56,9\% são públicas e comportam 40,3\% das matrículas nessa categoria; enquanto $43,1 \%$ são privadas e responsáveis por $59,7 \%$ das matrículas no setor. (INEP, 2015).

${ }^{26}$ De mais interesse ao setor privado, 92,5\% dos centros universitários e 93,2\% das faculdades são privadas. (INEP, 2015).
} 
Contudo, ainda que passar por uma avaliação seja prerrogativa obrigatória às IES, na prática do dia a dia das mesmas, ressignificações aos objetivos das avaliações são sempre possíveis; e, por fim, a qualidade de cada uma acaba passando pelo crivo da classificação acadêmico-administrativa as quais pertencem. Isso chama a atenção à contradição a qual o próprio Estado se coloca. Esse, quando submete todas as IES aos mesmos processos avaliativos, cobra um mesmo padrão de qualidade mínima a todas - sejam elas privadas ou públicas -, no entanto, no dia-a-dia é exigido naturalmente menos das faculdades e centro universitários - em geral privados.

Como chama a atenção Sguissardi (2008), o que acontece é que a LDBEN (1996) nascera à sombra das recomendações do documento La enseñanza superior: las lecciones derivadas de la experiencia, do BM, publicado em 1995 e citado no tópico seguinte. Tal documento propunha, entre outras considerações, o pagamento de alguma quantia pelo estudante até mesmo em instituições públicas, além de incentivar a se ter mais universidades de ensino (sem pesquisa) nos países em desenvolvimento.

Dessa forma, essa lei, ainda que não tenha exigido pagamento de mensalidades em instituições públicas ou proibido a continuidade de instituições voltadas à pesquisa, possibilitou todas as flexibilidades à iniciativa privada e ainda deu abertura, por exemplo, à "edição de diversos decretos normalizadores imbuídos do espírito dessas recomendações." (SGUISSARDI, 2008, p. 1000). Entre esses, cita-se o Decreto n. 2.306, de 19 de agosto de 1997, o qual reconheceu a educação superior, e especificamente a educação superior privada, como um serviço comercializável e lucrativo e, porque não dizer, como mercadoria. De acordo com esse documento, as

[...] instituições privadas de ensino classificadas como particulares, em sentido estrito, com finalidade lucrativa, ainda que de natureza civil, quando mantidas e administradas por pessoa física, ficam submetidas ao regime de legislação mercantil, quanto aos encargos fiscais, parafiscais e trabalhistas, como se comerciais fossem, equiparados seus mantenedores $\mathrm{e}$ administradores ao comerciante em nome individual. (BRASIL, 1997, art. $\left.7^{\circ}\right)$.

Assim, como mostra Fávero e Sguissardi (2012, p.75), esse decreto, "além de reconhecer uma realidade já existente, abriu as portas da educação superior para o denominado mercado educacional.". Vê-se que as IES privadas do tipo particulares representadas por pessoa física passam a responder ao mesmo regime que responde, por exemplo, uma loja qualquer. Na CF de 1988 já se identificava o Estado privando-se de uma 
obrigatoriedade com o oferecimento de uma educação superior pública e dando abertura à iniciativa privama; na LDBEN e decretos provenientes dela, isso se confirma e se amplia; e, cada vez mais, o sentido de educação superior idealizado, por exemplo, por Anísio Teixeira, esvazia-se, dando lugar à finalidade lucrativa.

Na sequência das disposições legais envolvendo a educação superior o aval do Estado a uma educação com foco no lucro continua persistindo. Ainda cabe recordar, por exemplo, o documento que indicaria diretrizes e metas educacionais para a década de 2001 a 2010 - o PNE, instituído pela Lei no 10.172/2001. Esse, segundo suas disposições gerais,

[...] estabelece prioridades que contemplam a diminuição das desigualdades sociais e regionais, a universalização da formação escolar mínima compatível com as necessidades da sociedade democrática moderna, a elevação global do nível de escolaridade da população e a melhoria geral da qualidade do ensino (BRASIL, 2001).

Entre essas prioridades, o PNE em questão indicava a necessidade de ampliar a oferta da educação superior para, pelo menos, 30\% da faixa etária de 18 a 24 anos até 2010, já que “conforme consta no diagnóstico do referido Plano, na época da sua elaboração somente $12 \%$ de jovens nessa faixa etária se encontravam matriculados na Educação Superior.” (BONETI; GISI; FILIPIKI, 2013, p. 527).

Para ampliar a oferta em tais proporções, o Plano também trouxe como meta que o setor público alcançasse "uma expansão de vagas tal que, no mínimo, mantenha uma proporção nunca inferior a 40\% do total”. (BRASIL, 2001). Isso exigiria que o Estado investisse na educação superior pública, sendo um pouco mais provedor. No entanto, chama atenção o fato de essa meta ter sido vetada pelo presidente da época - FHC. Com isso, o mesmo absteve o governo dessa responsabilidade e confirmou o claro aval do Estado a uma expansão desenfreada da educação privada em detrimento do crescimento e desenvolvimento da educação pública. Além disso, mostrou que esse documento continuaria seguindo a tendência das legislações em vigência - demarcando diferenciações entre as IES e facilitando a multiplicação daquelas que oferecem menos aos alunos: as faculdades e centros universitários, em geral pertencentes ao segmento privado.

Quanto à avaliação, foi definido no PNE em questão que a "União instituirá o Sistema Nacional de Avaliação e estabelecerá os mecanismos necessários ao acompanhamento das metas constantes do Plano Nacional de Educação" (BRASIL, 2001, art. $4^{\circ}$ ). E isso, para a autora deste trabalho, é a instauração de mais uma contradição na história da política avaliativa em vigência - o Sinaes. A prerrogativa do Plano mostra que não era desejável que 
se criasse uma avaliação isolada, representada por uma prova, por exemplo, mas sim um sistema avaliativo. A criação de um sistema pressupõe que o Estado queria empreender um conjunto de avaliações mais elaborado e dialógico, em que qualquer resultado específico fosse analisado sempre dentro do contexto do sistema avaliativo e não isoladamente. Em outras palavras, o PNE 2001-2010 indicaria que o Estado não poderia, por exemplo, subsidiar a elaboração de rankings de IES, já que isso proveria especificamente da avaliação do estudante. Tudo deveria ser encarado na perspectiva de um sistema; e a competitividade e vontade de destaque, tão típicas do mercado educacional, não teriam vez. No entanto, como se verá no decorrer desta dissertação, isso não é colocado integralmente em prática.

A LDBEN e esse primeiro PNE, “com os vetos presidenciais no que se refere ao financiamento, revelam a lógica intrínseca à política deliberada de privatização da educação superior.". (DOURADO, 2002, p. 89). Ao mesmo tempo, o último indica o aval do Estado a uma política sistêmica para a avaliação da educação superior, contrariando, em parte, o mercado. No período de implantação desse plano o sistema avaliativo foi criado, se instituindo em 2004 o Sistema Nacional de Avaliação da Educação Superior. E ao fim da vigência do Plano outro foi instituído, passado alguns anos.

O novo PNE - Lei n. 13.005/2014 -, fundado no governo de Luís Inácio Lula da Silva, ficou estabelecido para o período de 2014-2024. Esse trazia como metas, entre outras, a de número 12, a qual previa "elevar a taxa bruta de matrícula na Educação Superior para $50 \%$ e a taxa líquida para $33 \%$ da população de 18 a $24 \operatorname{anos}^{27}$, assegurada a qualidade da oferta e expansão para, pelo menos, $40 \%$ das novas matrículas, no segmento público" (BRASIL, 2014, meta 12, grifo nosso). O Estado, agora já contando com um sistema de avaliação da educação superior, passa a declarar, por lei, que a expansão pode ocorrer naturalmente, mas assegurada a qualidade da oferta.

Observando a tabela a seguir, elaborada por Griboski (2014) com base nos dados do Instituto Brasileiro de Geografia e Estatística (IBGE) e na Pesquisa Nacional por Amostra de Domicílios (PNAD), se perceberá que a expansão prevista pode até ocorrer, mas que a garantia da qualidade não se enxerga em números. Nela encontra-se a evolução das taxas de escolarização bruta e líquida na educação superior para o país e para cada região.

\footnotetext{
27 Taxa bruta é o percentual de população na educação superior sobre o universo da população de 18 a 24 anos e taxa líquida é o percentual da população de 18 a 24 anos na educação superior.
} 
Tabela 1 - Evolução das taxas de escolarização bruta e líquida na educação superior - Brasil e Regiões (2001-2011)

\begin{tabular}{c|l|l|l|l|l|l|l|l|l|l}
\hline \multirow{2}{*}{$\begin{array}{c}\text { Brasil/ } \\
\text { Regiões }\end{array}$} & \multicolumn{7}{|c}{ Educação superior (18 a 24 anos) } \\
\cline { 2 - 11 } & 2001 & 2002 & 2003 & 2004 & 2005 & 2006 & 2007 & 2008 & 2009 & 2011 \\
\hline Brasil & 15,1 & 16,6 & 18,6 & 18,6 & 19,9 & 22,6 & 24,3 & 25,5 & 26,7 & 27,8 \\
\hline $\begin{array}{c}\text { Centro- } \\
\text { Oeste }\end{array}$ & 18,2 & 21,8 & 23,6 & 23,2 & 25,9 & 27 & 28,8 & 31,1 & 32,6 & 37,3 \\
\hline Nordeste & 9,1 & 9,5 & 10,9 & 11,1 & 11,9 & 14,3 & 15,9 & 16,9 & 18,4 & 21,4 \\
\hline Norte & 11,3 & 15,3 & 14,7 & 12,2 & 14,6 & 17 & 19,3 & 21,7 & 23,7 & 23,6 \\
\hline Sudeste & 17,3 & 19 & 21,2 & 22 & 23,3 & 26,7 & 28,6 & 29,4 & 30,1 & 29,3 \\
\hline Sul & 21,3 & 22,8 & 26,7 & 26,5 & 27,8 & 29,7 & 30,8 & 32,9 & 3,5 & 34,2 \\
\hline $\begin{array}{c}\text { Brasil/ } \\
\text { Regiões }\end{array}$ & 2001 & 2002 & 2003 & 2004 & 2005 & 2006 & 2007 & 2008 & 2009 & 2011 \\
\hline Brasil & 8,9 & 9,8 & 10,6 & 10,5 & 11,2 & 12,6 & 13,1 & 13,7 & 14,4 & 14,6 \\
\hline Centro- & 9,7 & 11,8 & 12,3 & 12,2 & 14 & 14,8 & 15,6 & 16,3 & 17,9 & 19,7 \\
Oeste & & & & & & & & & & \\
\hline Nordeste & 5,1 & 5,1 & 5,8 & 5,9 & 6,1 & 7,1 & 7,7 & 8,3 & 9,4 & 10,6 \\
\hline Norte & 5,2 & 6,7 & 6,1 & 5,7 & 7 & 7,6 & 9 & 9,9 & 11 & 10,4 \\
\hline Sudeste & 10,9 & 12 & 12,8 & 13 & 13,8 & 15,7 & 16,4 & 16,6 & 16,8 & 16,1 \\
\hline Sul & 12,7 & 13,7 & 15,9 & 15,3 & 16,2 & 17,1 & 16,8 & 18,7 & 19,2 & 18,6 \\
\hline
\end{tabular}

Fonte: Griboski (2014, p. 209).

Nota: Para os anos 2001, 2002 e 2003, foi excluída a população rural de RO, AC, AM, RR, PA e AP.

Para atingir a meta 12 do PNE 2014-2024 na escolarização superior bruta, a matrícula deverá atingir 50\% até 2024. De 2001 a 2011 - período de 10 anos - o percentual passou de $15,1 \%$ a $27,8 \%$, aumentando em $84,10 \%$. Considerando um aumento proporcionalmente equivalente nos anos subsequentes, percebe-se que o alcance dos $50 \%$ é algo possível. A taxa de matrícula líquida, por sua vez, aumentou 64\%, passando de 8,9\% a 14,6\% no mesmo período; e deverá chegar aos 33\% até 2024.

Ainda que se consiga atingir esses percentuais, não é possível garantir que isso aconteça de forma equânime em todo o país. Tentativas de redução das assimetrias regionais vêm sendo realizadas; e destaque especial se dá ao período de 2003 a 2007, o qual se caracteriza como uma fase de interiorização da educação superior brasileira. À época, "foram implantados 79 novos câmpus universitários federais, distribuídos pelas cinco regiões brasileiras: $20 \%$ na região norte; $20 \%$ na região sul; $5 \%$ na região centro-oeste, $39 \%$ na região 
nordeste e 16\% na região sudeste." (MEC, 2014). Com esses dados, percebe-se que, sobretudo, na região Nordeste o investimento na expansão de campus de IES federais foi bastante significativo, no entanto, como se percebe na tabela 1, a Norte e a Nordeste apresentam, ao longo dos anos, taxas de escolarização bruta e líquida menor que as dos outros estados.

Ademais, tampouco é possível assegurar que, conforme o que exige o Plano, a implementação da expansão ocorra com a orientação da qualidade (GRIBOSKI, 2014). Como estratégia para garantir a qualidade, por exemplo, a meta 12 exige que se eleve gradualmente a taxa de conclusão média dos cursos de graduação presenciais nas universidades públicas para $90 \%$ e nas instituições de educação superior privada - inclusive universidades - para 75\%. A diferenciação, então, continua, e mesmo das universidades passa-se a se exigir menos se privadas. Com base nisso, Minto (2015), por exemplo, afirma que a educação privada é tratada de forma mais "branda".

A meta 13 do mesmo PNE, por sua vez, prevê a elevação da proporção de mestres e doutores nas IES públicas e privadas para 75\%, sendo, desse total, no mínimo 35\% doutores. Em 2014, contudo, a rede pública de educação superior tinha 55,8\% do seu quadro de professores efetivos com doutorado, 28,8\% com mestrado e 15,4\% com especialização. Já a privada, tinha apenas $19,8 \%$ do quadro com doutorado, $47 \%$ com mestrado e $32,2 \%$ com especialização (INEP, 2015). Consequentemente, não se sabe a custas de qual setor se vai atingir essa previsão. Além disso, essa mesma meta prevê elevar a qualidade da educação superior no país por meio: do aperfeiçoamento do Sinaes no que tange às ações de avaliação, regulação e supervisão; da ampliação da cobertura do Enade; e da indução de

[...] processo contínuo de autoavaliação das instituições de educação superior, fortalecendo a participação das Comissões Próprias de Avaliação, bem como a aplicação de instrumentos de avaliação que orientem as dimensões a serem fortalecidas, destacando-se a qualificação e a dedicação do corpo docente. (BRASIL, 2014, meta 13).

Estaria, portanto, no Sistema Nacional de Avaliação da Educação Superior e, dentro desse, na autoavaliação institucional, a garantia de que a expansão ocorreria com vistas à qualidade? Mas que qualidade é essa dentro do contexto de expansão? Com base na legislação, vê-se que a diferenciação entre (i) universidades e demais segmentos acadêmicoadministrativos; e, sobretudo, entre (ii) setor público e privado é o que determina tanto o tipo de IES que vai expandir em termos quantitativos, como a finalidade principal dessas IES - se o lucro ou algo mais que isso. 
Legislações que diferenciam instituições privadas e públicas, esperando sempre mais das últimas, podem até, às vezes - como no caso do PNE 2014-2024 - lembrar-se da avaliação, e especificamente da autoavaliação, como peças importantes na garantia da qualidade, contudo, não podem colocar nessa ou em outra política avaliativa o peso de equalizar a qualidade de IES tão diferentes, por exemplo. As avaliações da educação superior, como comentado nas considerações iniciais deste trabalho, foram criadas, entre outros motivos, para regular a expansão, entretanto, a nenhuma se pode atribuir com seguridade tal poder.

Refletindo todas as ações do Estado citadas até o momento, a tabela 2, a seguir, tornase bastante pertinente à discussão. A partir da tabela, em que se encontra a evolução do número de IES nas últimas três décadas ${ }^{28}$, vê-se claramente que, tal como já esperado, houve crescimento exacerbado do setor privado desde 1980, enquanto o setor público - não regido pelo capital -, cresceu consideravelmente, mas menos que o primeiro.

Tabela 2: Evolução do número de IES no Brasil - 1980 a 2014

\begin{tabular}{c|c|c|c}
\hline ANO & Instituição pública & Instituição privada & TOTAL \\
\hline 1980 & 200 & 682 & 882 \\
\hline 1990 & 222 & 696 & 918 \\
\hline 1995 & 210 & 684 & 894 \\
\hline 2000 & 176 & 1.004 & 1.180 \\
\hline 2001 & 183 & 1.208 & 1.391 \\
\hline 2002 & 195 & 1.442 & 1.637 \\
\hline 2003 & 207 & 1.652 & 1.859 \\
\hline 2004 & 208 & 1.842 & 2.050 \\
\hline 2005 & 231 & 1.934 & 2.165 \\
\hline 2006 & 248 & 2.022 & 2.270 \\
\hline 2007 & 249 & 2.032 & 2.281 \\
\hline 2008 & 236 & 2.016 & 2.252 \\
\hline 2009 & 245 & 2.069 & 2.314 \\
\hline 2010 & 278 & 2.100 & 2.378 \\
\hline 2011 & 284 & 2.081 & 2.365 \\
\hline 2012 & 304 & 2.112 & 2.416 \\
\hline 2013 & 301 & 2.090 & 2.391 \\
\hline 2014 & 298 & 2.070 & 2.368 \\
\hline
\end{tabular}

Fonte: Inep (2015).

28 Apesar de se reconhecer a importância de compreender a evolução da educação superior do Brasil desde seus primórdios, optou-se nesta cessão por restringir-se às três últimas décadas, em consonância com a contemporaneidade do objeto da pesquisa. Outrossim, vale ressaltar que em todo o "período que se estendeu até a Constituição de 1988 detecta-se uma continuidade representada pela prevalência do modelo napoleônico de universidade na organização e expansão do ensino superior no Brasil.” (SAVIANI, 2010, p. 4). 
Como se pode perceber na tabela, no ano de 1980 a quantidade de IES privadas ${ }^{29}$ já era superior à quantidade de públicas. Foi na década de 1980, contudo, que o ensino superior público foi instalado em áreas geográficas de menor interesse para a rede privada (SOUSA, 2003), além de datar de 1983 a criação da primeira proposta de política sistemática de avaliação da educação superior brasileira do país - o Programa de Avaliação da Reforma Universitária (Paru). A expectativa com esse projeto avaliativo foi que, entre outras inovações, seus resultados ajudassem na regulação da expansão da educação, proporcionando um crescimento mais equânime entre setor público e privado.

Entre os anos de 1980 e 1990, período em que se aloca a promulgação da CF de 1988, o crescimento geral do número de instituições de educação superior no país foi pouco expressivo, passando de 882 a 918. Mas, ao contrário do que se poderia imaginar, isso não ocorreu devido ao estabelecimento de políticas públicas de avaliação ou à expansão de instituições públicas a outras áreas geográficas, senão devido à crise econômica pela qual o país passava. Com um grave quadro inflacionário e aumento das taxas de desemprego à época, a demanda por ensino superior diminuiu e, por conseguinte, ocorreu uma desaceleração da expansão no setor, tendo sido suspensa inclusive a criação de novos cursos nas instituições existentes ${ }^{30}$. (MARTINS, 2009).

Na década de 1990, a expansão acelera-se. No Distrito Federal, local onde se localiza o corpus desta pesquisa, chegou-se no ano de 1993, segundo Sousa (2003), a um total de quatorze instituições de educação superior. Eram onze estabelecimentos isolados, duas faculdades privadas e uma única universidade pública - a Universidade de Brasília, inaugurada em 1962. Além das motivações locais para o crescimento do setor privado no período $^{31}$, tem-se que no país, como um todo, isso se deu tanto pela maior estabilidade financeira, como pelas condições legais favoráveis dadas ao setor privado quando da

\footnotetext{
${ }^{29}$ O ensino superior brasileiro em seus primórdios era exclusivamente promovido pela esfera pública. "O ensino superior privado no Brasil tem suas origens na última década do século XIX, quando a Constituição da República, promulgada em 1891, estabeleceu a descentralização desse nível de ensino, até então mantido com exclusividade pelo poder central." (SOUSA, 2003, p. 14).

${ }^{30}$ Nesse sentido, merece destaque "o Decreto 86.000/81, com vigência de 13.05 .81 a 31.12 .82 , que suspendia temporariamente a criação de novos cursos de graduação em universidades e outras IES; Decreto 91.694/85, com vigência entre 27.09.85 a 30.09.86, que proibia a criação de novos cursos de Direito em todo o Território Nacional". (SOUSA, 2003, p. 20).

${ }^{31}$ Conforme Sousa (2003), entre os motivos que explicam a instalação das IES privadas no DF até o ano de 1993, destaca-se (i) o crescimento populacional do DF, o qual aumentou de maneira significativa entre os anos de 1970 e 1992; (ii) o fato de grande parte da população estar relacionada ao setor terciário em 1989; e (iii) o crescimento lendo da Universidade de Brasília à época, o qual não era compatível com as demandas da população.
} 
promulgação da Constituição Federal de 1988 e da Lei de diretrizes e bases da educação nacional, de 1996.

A instabilidade econômica já vinha sendo gradativamente contida e, com a publicação da $\mathrm{CF} / 88$, o crescimento desse setor passa a ser legalmente respaldado, já que, como visto, era permitida ao mesmo a criação de instituições de educação de tipos diversos, desde que passando por avaliação. Somado a isso, as condições para o crescimento da rede privada se tornaram mais propícias, visto que a referida lei, além de preferir a responsabilidade privada à pública,

[...] reserva à educação superior um conjunto de princípios que indicam alterações para esse nível de ensino, balizado, de um lado, paradoxalmente, pelos processos ditos de descentralização e flexibilização presentes nessa legislação e, de outro lado, por novas formas de controle e padronização por meio de processos avaliativos estandardizados. (DOURADO, 2002, p. 242).

Posteriormente à $\mathrm{CF}$ e com os acréscimos da LDBEN, veem-se nos dados expostos na tabela antes apresentada que de 1995 a 2002 - período que corresponde aos dois mandatos do presidente FHC - o número de IES aumentou consideravelmente no país, mas sempre com prevalência do setor privado. No DF, ainda que não ilustrado na tabela, pode-se afirmar que esse foi um período no qual houve um boom de crescimento do setor privado. Enquanto em 1995 contava-se com uma IES pública e 12 privadas, em 2001 chega-se a duas IES públicas UnB e Fundação de Ensino e Pesquisa em Ciências da Saúde (Fepecs) ${ }^{32}$-, bem como 63 $\operatorname{privadas}^{33}$. (HORA, 2013).

À época, contava-se com a política de avaliação denominada Exame Nacional de Cursos (ENC), popularmente conhecido como "Provão"; e com essa política veio a promessa da ampliação da qualidade mediante a ameaça de fechamento de cursos, o que nada tinha de formativo. Bem representativa das deliberações de organismos internacionais, essa avaliação tinha foco no resultado e previa mudanças por meio de pressão, não tendo, portanto, preocupação com a parte formativa. Curiosamente, no entanto, "nenhum curso ou IES teve as suas atividades encerradas, o que evidencia que o único resultado concreto foi o da expansão

\footnotetext{
${ }^{32}$ A Fepecs foi criada em 12 de janeira de 2001, por meio da Lei Distrital nº 2.676/2001. (GDF, 2001).

${ }^{33}$ Conforme Sousa (2003), as causas da expansão da educação superior privada do DF entre 1995 e 2001 foram: "(i) demanda existente e que não vinha sendo atendida pela única instituição pública e os estabelecimentos privados no período entre 68 e 93; (ii) o estímulo apresentado pela política educacional definida, na década [de 1990] para esse nível de ensino; (iii) a rentabilidade atribuída ao segmento privado da educação superior; (iv) o interesse de alguns proprietários de escolas de educação básica em aproveitar a estrutura que seus estabelecimentos já possuíam; (v) o nível de renda da população local, considerando elevado em relação ao de outras unidades federativas" (p. 38).
} 
acelerada da educação superior, sobretudo privada." (OLIVEIRA; FONSECA; AMARAL, 2006, p. 81).

O fato de nem a avaliação centralizadora, da qual só se espera mesmo medidas regulatórias, ter fechado sequer um curso em todo o país sinaliza que o que era primordial mesmo para o Estado brasileiro era o desenvolvimento econômico, com a expansão livre do capital e, no caso, das IES. Prova disso é que o número de instituições públicas de educação superior no país decaiu de 210 a 195, enquanto de IES privadas subiu de 684 a 1.442, no governo FHC. Para Assis e Oliveira (2013), esse crescimento descontrolado do setor teria inclusive desencadeado a abertura de um "quase-mercado",34, consideravelmente lucrativo e gerador de competitividade entre as instituições educativas. E isso teria acarretado, por sua vez, "mudanças profundas no encaminhamento das políticas institucionais, tornando mais evidente as intenções de lucro das IES privadas, que adotaram o discurso e as práticas da gestão empresarial, inserindo-se no "mercado educacional."” (p. 56-57).

De acordo com Silva; Ferro e Arruda (2015), a universidade brasileira, independente do período, vem atendendo às demandas do capitalismo, sendo, inclusive, instrumento de agregação de valor ao capital. Ao mesmo tempo, segundo os autores, ainda que o capitalista preveja que o capitalismo é infinito, também tem a consciência de que o mercado, do contrário, não é; ficando as IES, nesse contexto, responsáveis por ajudar a movimentar o mercado. Em suma, a educação superior

[...] se apresenta como um meganegócio que ocupa alunos-trabalhadores que não conseguem vender sua força de trabalho, compra força de trabalho [docentes] (no exército industrial de reserva) para produzir a mercadoria ensino e reproduz capital, proporcionando, assim, um amplo mercado de produtos de toda natureza, que são necessários à implementação da escola como é materializada na sociedade contemporânea. (SILVA; FERRO; ARRUDA, 2010, p. 10).

Com a instauração do primeiro PNE (2001-2010), aprovado no fim do segundo mandato de FHC, havia surgido a esperança de que as políticas públicas educacionais, e a educação superior, propriamente dita, deixassem de ceder tanto à lógica capitalista. Contudo,

\footnotetext{
${ }^{34}$ A noção de "quase mercado" tem origem na proposta de Milton Friedman, para quem poderia existir mecanismos de vouchers para que os pais de alunos pudessem escolher, mesmo sem condição financeira, a escola onde matricular seu filho. Nas últimas décadas outra tendência de quase mercado emergiu com o chamado school choice. Esse visa proporcionar a livre opção de escola para pais e alunos ao oferecer subsídios e criar competição entre as instituições. Na educação superior, especificamente, essa noção caracteriza-se pela redução dos financiamentos públicos seguida da expansão das redes de instituições privadas e maior competição entre as instituições, o que reorienta tanto IES públicas como privadas nos princípios e lógicas do mercado. (BERTOLIN, 2011).
} 
nenhuma mudança nesse sentido foi detectada, pois, com o veto do presidente, anteriormente comentado, deu-se continuidade à expansão desenfreada da educação privada em detrimento do crescimento da educação pública como, agora, se percebe no quadro. Ademais, em consonância às legislações anteriores, a avaliação formativa e, logo, a autoavaliação, continuava sendo desconsiderada. Já na mudança de governo, em 2003, em virtude da ascensão de Luís Inácio Lula da Silva ao cargo de Presidente da República, houve, por sua vez, uma

[...] reorientação da política educacional, no sentido de fortalecer o ensino público, sobretudo nas universidades federais. Embora a gestão do primeiro ministro do novo governo não sinalizasse claramente a recuperação das instituições federais, a partir de 2004 foram colocadas em prática determinadas ações visando reverter a situação adversa em que estas se encontravam nos anos anteriores. Seu orçamento foi recuperado, houve implantação de novas unidades, contratação de novos docentes e funcionários mediante concurso público, cujos salários foram atualizados. (MARTINS, 2009, p. 26).

Também aconteceu, em 2004, a instituição do Sinaes - Lei no 10.861, de 14 de abril de 2004 - e com ele a expectativa por uma avaliação que preservasse de forma equilibrada a regulação e a avaliação formativa, já que esse era em um sistema avaliativo. Essa política de avaliação, à época, constituiu-se, realmente,

[...] em avanço de um modelo de avaliação da educação superior no Brasil, que promovia o ranking e a competitividade, baseado em estratégias de visibilidade mercadológica, para um paradigma que propõe a avaliação formativa ao incluir a auto-avaliação [sic] participativa nas instituições e propor sua articulação com a regulação do sistema. (POLIDORI; MARINHO-ARAUJO; BARREYRO, 2006, p. 434).

Não obstante, de 2003 a 2010 - período que corresponde aos dois mandatos do presidente Lula -, o número de IES privadas continuou crescendo, ainda que mais timidamente, passando de 1.652 a 2.010. E o setor público, por sua vez, expandiu-se como nunca, passando de 207 a 278 instituições no período, representando um aumento percentual de $34 \%$. Esses percentuais e o fato de se ter implementado um sistema avaliativo cuja proposta era formativa não significou, contudo, que a lógica neoliberal de abertura ao privado teria encontrado limite no governo Lula e nem que a qualidade seria entendida como algo amplo e intrínseco ao contexto de cada IES. 
Além da prioridade dada ao Enade, levantamento feito em 2008 pelo jornal Folha de S. Paulo mostrou que de nove instituições reprovadas pelo MEC por obterem conceitos 1 e 2 no Índice Geral de Cursos (IGC) - um dos instrumentos avaliativos do Sinaes provenientes do Enade -, em seis a autorização era anterior a 1996. "Especialistas afirmam que a situação demonstra uma falha do MEC no controle da qualidade das escolas, tanto da gestão FHC quanto Lula. A pasta admite o problema, mas afirma que criou mecanismos para aperfeiçoar o sistema." (TAKAHASHI, 2008, p.1). Assim, mesmo no sistema avaliativo vigente - o Sinaes -, o qual pretendia, conforme se verá no capítulo 2, superar avaliações anteriores, até os atos explicitamente regulatórios podem ser falhos, como o foram nessa situação denunciada pelo jornal citado.

Além disso, apesar das IES públicas, no governo Lula, não terem sido preteridas, visto que várias foram inauguradas e contaram com maior investimento público que antes nesse período, isso não significou freio ao capital. As IES privadas talvez não apresentaram grande expansão, comparativamente a tempos anteriores, por terem sido incorporadas a grupos maiores, seguindo uma tendência mundial, e não por terem sofrido alguma dificuldade por parte do governo. Em 2013, por exemplo, a Kroton incorporou a Anhanguera Educacional e passou a concentrar "em torno de $1 / 6$ do alunado do setor em suas unidades (928.896 matriculados no $1^{\circ}$ trimestre de 2014) - ou seja, $1 / 8$ dos alunos do ensino [sic] superior do país.” (GASPAR; FERNANDES, 2015, p. 85).

A finalidade reinante, nesse sentido, continuaria sendo a lucratividade, a competitividade e o atendimento ao mercado de trabalho, por conseguinte, ao que parece, às vezes para o Estado vale tudo em prol do dinheiro. Segundo dados do Censo da Educação Superior publicado em 2015, por exemplo, tem-se que em 2014, pela primeira vez, as funções docentes da rede privada em tempo parcial superam as horistas. Os dados mostram que $24,4 \%$ das funções docente são de tempo integral, 40,4\% de tempo parcial e 35,2\% horista. (INEP, 2015).

Apesar de o avanço de se ter mais docentes com dedicação de tempo parcial do que horistas, não é possível saber qual a condição de trabalho do professor das instituições de educação superior privada diante do contexto das fusões institucionais. Segundo Gaspar e Fernandes (2015), em 2010, a empresa educacional Kroton, anteriormente referenciada, comprou a IUNI Educacional, IES sediada no estado de Mato Grosso, e reduziu 1.079 funcionários do quadro. Em 2011 a empresa Anhanguera Educacional, por sua vez, comprou a Universidade Bandeirante (Uniban), no estado de São Paulo, demitindo, em seguida, 600 trabalhadores. Ademais, em 1999, segundo os mesmos, os docentes da Uniban tinham um 
piso salarial de $\mathrm{R} \$ 15,52$ a hora-aula, “que, corrigido pela inflação até 2013, deveria estar em $\mathrm{R} \$ 38,66$. No entanto, o piso da Anhanguera, atual proprietária da IES, está em torno de R\$ 30,00.’. (p. 87).

Vale lembrar que esses grandes grupos passaram a também fundirem-se na forma de holdings, colocando suas ações nas bolsas de valores e tomando mais do que nunca uma orientação voltada especialmente ao lucro. Com ações na bolsa, as IES privadas (particulares) tornam-se mercadorias passíveis de serem compradas por investidores estrangeiros ou nacionais e crescem de maneira tão vertiginosa que acabam por gerar concorrências desequilibradas.

\begin{abstract}
A facilidade que as empresas de capital aberto atuantes no campo educacional têm de ampliar seu capital via bolsa de valores - quando investidores privados, pessoas físicas e principalmente jurídicas, do mundo inteiro podem comprar suas ações - está significando uma competição extremamente desigual com as IES privadas sem fins lucrativos, como as comunitárias e confessionais e mesmo particulares de propriedade familiar, sem capital aberto, o que está levando à falência ou à redução drástica do número de IES e de sua capacidade de atrair e manter estudantes [...]. (FÁVERO; SGUISSARDI, 2012, p. 82).
\end{abstract}

O governo subsequente, da presidenta Dilma Rousseff, por fim, apresentou em seu primeiro mandato (2011-2014) continuidade do governo Lula no que tange à expansão da educação superior pública, e também fusões do setor privado. Logo em 2 de agosto de 2011 a presidenta "anunciou a continuidade do "Plano de expansão da Rede Federal de Educação Superior e Profissional e Tecnológica" mediante a construção de quatro novas universidades federais, 47 novos campi universitários e 208 Institutos Federais Tecnológicos”. (FERREIRA; OLIVEIRA, 2013, p. 9).

Os dados do último censo publicado, referente ao ano de 2014, por sua vez, demonstram uma expansão muito superior a quatro novas IES públicas. Como mostrado antes na tabela 2, a quantidade saltou de 278 IES no último ano do governo Lula (2010) para 298 no último ano do primeiro mandato do governo Dilma (2014), o que representa um crescimento percentual de 7,2\%. O número de IES privadas decaiu de 2.100 em 2010 para 2.070 em 2014, representando uma diminuição percentual de 1,4\%, mas, como visto, isso não significa freio ao capital. A expansão do setor privado educacional sempre prevaleceu sob a do setor público (SOUSA, 2006), ainda que os governos de Lula e Dilma dessem atenção também a esse último, expandindo-o consideravelmente. 
A legislação referente à educação superior foi complacente com as IES privadas, tanto no que tange a facilitar a abertura dessas, como a exigir menos daquelas que representam quantitativamente o segmento: faculdades e centro universitários. A finalidade do Estado, transferida às IES é, de modo geral, fazer girar a engrenagem do mercado, produzindo mão de obra a esse. Como reflexo disso, as políticas de avaliação, basicamente, (i) foram implementadas naturalmente em todo país em cumprimento às legislações; (ii) sofreram críticas por ora terem caráter centralizador - como o ENC - ora terem caráter formativo, porém mais intencional do que prático, - como o Sinaes -; (iii) mas sempre, independente do caráter, estiveram aparentemente cuidadosas com a garantia da continuidade do desenvolvimento econômico do país ou, em outras palavras, com a expansão da educação superior.

Devido à própria segmentação acadêmico-administrativa, oficializada na LDBEN (1996), e comentada anteriormente, tornou-se atrativo ao setor privado a criação de faculdades e centro-universitários. O custo mais baixo desses segmentos acadêmicoadministrativos interessou ao mercado, o qual, com a abertura estatal lhe oferecida, viu na criação dessas IES uma forma mais fácil de investimento e aumento de capital. (SCHWARTZMAN; SCHWARTZMAN, 2002).

Sempre com vistas à lucratividade, no entanto, faculdades e centro-universitários parecem reconhecer que instituições do tipo universidades são "melhores", inclusive aos olhos dos seus clientes. Segundo Sousa (2004) mesmo o prefixo UNI sendo, de acordo com Secretaria de Educação Superior (SESu), do MEC, de uso privativo de universidades, sua utilização converteu-se em estratégia de marketing de algumas instituições do DF. De acordo com o autor, o dirigente de uma instituição da região,

[...] revelou que, para sua escola, a utilização do prefixo UNI constituiu-se uma boa estratégia de marketing. Essa tática era importante, segundo o mesmo informante, para sua escola competir com outras que ocupam posições dominantes e adotaram o mesmo prefixo, como, por exemplo, [duas IES], respectivamente centro universitário e faculdade. $\mathrm{O}$ argumento sustentado é que a comunidade geralmente não conhece, em detalhes, as diferenças entre universidade, centro universitário e faculdade. (p. 13).

Acredita-se que nem ao segmento do tipo universidade, o qual tem, necessariamente, que aliar conhecimento científico à preparação para o mercado de trabalho valendo-se da tríade ensino-pesquisa-extensão, é natural e fácil o alcance de algo próximo ao idealizado às IES por Anísio Teixeira, comentado no começo desta seção. Não obstante, o exemplo 
destacado de Sousa (2004) mostra que a universidade é objeto de desejo do mercado educacional pelo menos no que tange a valer-se de seu prefixo para ganhar competitividade. Nesse sentido, a autora desta pesquisa faz dos questionamentos de Fávero e Sguissardi (2012) os seus:

É possível esperar que empresas de ensino, que disputam na bolsa de valores os aplicadores globais, num mercado ainda completamente aberto e de baixa concorrência, consigam se orientar por um projeto institucional que vise à produção do conhecimento e sua melhor divulgação, que integre ensino, pesquisa e extensão, que forme cidadãos qualificados em termos técnicoprofissionais, mas, ao mesmo tempo, com aprofundada capacidade crítica do modelo de desenvolvimento dominante? Em outras palavras, podemos esperar que essas IES - cerca de 1.850 ou $77,8 \%$ do total das 2.378 do país tenham por função algo próximo do que Anísio Teixeira preconizava em 1935 e 1968 ao pensar as principais funções da universidade como foram antes explicitadas? (p. 83-84).

Esperava-se, como visto no decorrer deste item, que as instituições superassem a simples finalidade no mercado de trabalho, compreendendo que uma educação de qualidade pressupõe algo mais amplo que tornar seu egresso competitivo no mercado de trabalho, por exemplo. Contudo, ainda que das universidades se exija mais, o sistema educacional brasileiro, como um todo, subordinado às ações do Estado, parece rendido ao capital. É como se das universidades se esperasse tudo, enquanto das demais o mínimo; sendo exatamente o mínimo a parte que o Estado prefere. Esse, como visto, (i) fez, por muito tempo, investimento diminuto na educação superior pública, especialmente representada por instituições do tipo universidades; e (ii) instituiu legislação condizente com a expansão do setor privado. Qualidade, em um contexto como esse, não tem relação de causalidade com uma finalidade institucional que se aproxime daquela idealizada nos discursos de 1930 proferido pelo pensador Anísio Teixeira e reiterada por Sguissardi (2008), ainda que se tenha passado oito décadas.

As instituições de educação superior poderiam contribuir com a reestruturação do Estado com vistas ao desenvolvimento econômico sem que a elas fosse atribuído o cargo de "fator de desenvolvimento". Em outras palavras, elas poderiam ajudar a mover o mercado econômco sem que tivessem que se converter em um "quase-mercado", competitivo e preocupado com o lucro em primeiro lugar. Nas palavras do sempre atual Florestan Fernandes (1976), uma 
[...] sociedade nacional pode transformar-se de maneira acelerada e tumultuosa, sem que se possa falar, no entanto, que ela esteja se diferenciando no padrão organizatório de sua estrutura social, ou seja, que se encontre em desenvolvimento. Isso significa que a universidade pode se ver projetada no contexto de uma sociedade em mudança - e contribuir positivamente para o condicionamento, a orientação ou a intensificação de determinadas mudanças - sem que mereça ser qualificada, sociologicamente, como "fator de desenvolvimento". (p. 194).

Em nome da expansão do capital e da livre concorrência, no entanto, a oferta educacional foi deixada nas mãos de empresários. E, em nome do desenvolvimento econômico, foi possibilitado a esses empresários construírem instituições das quais se exige menos atributos - faculdades e centros universitários. A avaliação, em meio a esse processo que se pode chamar de mercadorização da educação, surge como a forma de o Estado marcar sua presença. Contudo, esse, tão rendido ao capital, às vezes nem cumpre com suas funções regulatórias que proviriam dos resultados avaliativos. O Sinaes, já no começo de sua implementação, era, diante desse contexto, entendido muitas vezes

[...] mais como controle do que como meio para a melhoria dos processos de gestão, de ensino, de pesquisa, de extensão e de alteração de práticas docentes. O papel regulador e controlador do Sinaes, definido como papel do Estado, vem assumindo maior relevância do que o de indutor do desenvolvimento das instituições, o que poderia ser alcançado por meio de uma avaliação mais processual e dialógica. (FONSECA; OLIVEIRA, 2007, p. 14).

Com o Sinaes, e a abertura a uma proposta avaliativa formativa, esperava-se que o foco na qualidade educacional, em sua complexidade e amplitude, se sobreporia ao foco do Estado no desenvolvimento econômico desmedido. Porém, como visto neste item, o tipo de instituição priorizada no Brasil é aquela direcionada à formação para o mercado de trabalho e não a uma formação mais ampla.

Nesse contexto, a educação, que deveria ser um direito e bem público, passou a ser, contraditoriamente, um serviço e bem privado/mercantil; e a regulação, que deveria defender o interesse público e do cidadão, bem como utilizar-se da avaliação formativa, passa a defender o setor privado e valer-se de avaliação centralizadora. A finalidade das IES, de modo geral, é o ensino para o mercado de trabalho, o que põe à mostra um Estado que não estaria preocupado, por exemplo, com a avaliação formativa, com a autoavaliação e com dar voz às instituições. O mercado poderia ser uma consequência da educação oferecida por uma instituição, contudo, ao longo do tempo e com suporte da legislação, passou a ser a finalidade. 
Muitas IES foram equiparadas explicitamente a uma empresa, a exemplo das particulares, e a educação a uma mercadoria.

A partir do momento em que o Estado mostra que sua preocupação é com a expansão da educação a qualquer custo, ele demonstra que aquele tipo de instituição defendida por Anísio Teixeira pode até ser idealizada, porém, não ganhará subsídios para ser implementada. Da mesma forma, essa atitude indica que o Estado, contraditoriamente, tenha criado o Sinaes sem concordar com a qualidade educativa almejada por essa política avaliativa. Rendido à própria égide capitalista, subsidia a expansão de instituições cuja qualidade pode reduzir-se a preparar o estudante para o mercado de trabalho. Avaliações como a autoavaliação, nesse contexto, nem têm vez. Empoderamento de sujeitos, discussões críticas e tomadas de decisões em prol de melhorias conscientes - pressupostos presentes em um contexto ideal de autoavaliação - podem ser de viabilidade difícil; e toda a legislação aqui discutida vem a confirmar isso.

\subsection{DIFICULDADES NA IMPLEMENTAÇÃO DE UMA AVALIAÇÃO FORMATIVA}

Se a autoavaliação não for valorizada dentro do sistema, tal como, com base no item anterior, já se pode inferir que acontece, as outras ferramentas podem até serem valorizadas, mas não são capazes de gerar, isoladamente, uma cultura avaliativa formativa e fomentadora de qualidade. O Sinaes prevê equilíbrio entre seus elementos constituintes para que seja possível implementar essa cultura, mas essa é uma façanha um tanto difícil de se alcançar. Como visto no item anterior, o desenvolvimento do Sinaes é influenciado por uma concepção de instituição de educação superior que vem sendo construída historicamente desde antes dele, a qual entende que: (i) a qualidade é dividida em níveis, de acordo com o que é esperado de cada segmento institucional; e (ii) a avaliação do estudante é a que reflete e fomenta a qualidade. $\mathrm{Na}$ continuidade, neste item, é preciso refletir sobre o que propõem como qualidade os dois tipos de avaliação existentes na educação superior brasileira - a formativa e a controladora -, tendo em mente que a autoavaliação, objeto do trabalho, insere-se em uma política avaliativa que se diz formativa.

A começar pela definição dos termos, tem-se que avaliação e regulação são naturalmente relacionados às políticas de educação, contudo, a abrangência conceitual de 
ambos demonstra que servem a várias motivações, sendo a educação uma delas. A avaliação, conforme salienta Dias Sobrinho (2010, p. 195),

[...] é a ferramenta principal da organização e implementação das reformas educacionais. Produz mudanças nos currículos, nas metodologias de ensino, nos conceitos e práticas de formação, na gestão, nas estruturas de poder, nos modelos institucionais, nas configurações do sistema educativo, nas políticas e prioridades da pesquisa, nas noções de pertinência e responsabilidade social. Enfim, tem a ver com as transformações desejadas não somente para a educação superior propriamente dita, mas para a sociedade, em geral, do presente e do futuro.

A regulação, por sua vez, é discutida aqui a partir das definições de quatro autores, cujas ideias acabam se complementando. De acordo com Verhine e Monteiro de Freitas (2012), que focam na etimologia da palavra, regulação é um vocábulo derivado do latim que designaria aquilo que regula, dirige, rege ou governa. Já conforme Kells (1999), em uma visão com mais detalhamento prático, regulação é um processo

[...] informado e periódico através do qual um sistema, uma instituição, um programa ou procedimento é, com o passar do tempo, colocado em sintonia com suas expectativas (intenções, padrões, normas), através de escolhas e ações julgadas necessária pelo(s) regulador(es), tendo como base o resultado de uma avaliação formativa. (p.9).

Finalmente, para Barroso (2005, p. 733), em uma perspectiva igualmente prática, regulação "compreende, não só, a produção de regras (normas, injunções, constrangimentos etc.) que orientam o funcionamento do sistema, mas também o (re)ajustamento da diversidade de acções dos actores em função dessas mesmas regras." Dessa forma, a partir das três visões apresentadas, tem-se que a regulação seria um conjunto de ações o qual, baseado no resultado de avaliações do tipo formativas e tendo como prerrogativa a criação de regras, subsidiaria a conformação de algo às expectativas do regulador.

A regulação da educação superior - nível que interessa a esta pesquisa - "configura-se no Brasil pelos atos de autorização, reconhecimento e renovação de reconhecimento de cursos, além daqueles relativos ao credenciamento/recredenciamento de instituições." (OLIVEIRA, et. al., 2013, p. 643). Isso significa que, inseridas ao contexto de regulação estatal, as IES necessitam adequar-se às expectativas de qualidade estabelecidas pelo Estado capitalista, a fim de que possam funcionar de forma regularizada. Face ao exposto, percebe-se que a ação de regular não se confunde, na teoria, com a ação de avaliar. Uma entidade reguladora pode fazer valer suas normativas sem utilizar-se de avaliações, por exemplo. No 
entanto, no caso da educação superior no Brasil, em que regular pressupõe desde o reconhecimento de um curso até o fechamento de uma IES, a avaliação se tornou a ferramenta principal da regulação. Teoricamente, vale ressaltar, avaliação e regulação são ações

[...] distintas e devem se completar. A função de regulação, de responsabilidade do Estado, instaura procedimentos de controle e fiscalização para assegurar as condições de existência de um sistema de boa qualidade e necessariamente consolidado como um serviço público. Esta função não deve se esgotar em si mesma. A regulação deve se articular com a função de avaliação educativa, que, para além do mero controle, se desenvolve como prática social voltada à produção da qualidade das instituições e da emancipação social. (DIAS SOBRINHO, 2003, p. 38).

Na prática, no entanto, nem sempre essas duas ações ocorrem como aludido por Dias Sobrinho (2003). Ainda que a regulação e a avaliação devessem se completar, no cenário atual questiona-se a prevalência da primeira sobre a segunda na prática das políticas avaliativas educacionais, o que interfere, por conseguinte, no que se entende como a qualidade a ser fomentada.

O uso dos resultados da avaliação como indicadores para a regulação veio a instaurarse de forma sistematizada no Brasil e no mundo especialmente na década de 1980. Como visto nas considerações iniciais desta dissertação, o Estado preferiu não exercer um controle direto sobre os processos educacionais, senão regular os seus resultados.

No período logo após a segunda guerra mundial (1939-1945) propagou-se pelo mundo o walfare state, ou Estado de bem-estar social, cuja missão estava atrelada à assistência, prestação de direitos e garantia da liberdade e onde "o Estado passava a redefinir um padrão de regulação das relações sociais e de trabalho" (SILVA; MATTOS, 2009, p. 136). A regulação, nesse contexto, se dava por interferência direta da instância estatal, que se fazia presente tanto no oferecimento de determinado serviço, como no zelo do mesmo.

Entretanto, com o tempo, esse modelo se tornou economicamente insustentável e, especialmente a partir da segunda metade da década de 1970, passou a caminhar rumo a sua queda. Uma crise econômica mundial se instaurou à época e com ela uma profunda recessão, a qual serviu de desculpa para que o mundo, capitalista, voltasse a se desenvolver, mas sem assistir diretamente a população.

Nesse contexto, ainda que a preço de um elevado custo social, o neoliberalismo fora colocado como o único caminho que levaria ao reerguimento econômico. Por conseguinte, qualquer intervenção estatal era vista à época como um fator limitador da liberdade 
econômica e política (DOURADO, 2002; TEIXEIRA, 1996). Cabia aos Estados reformularem-se e aderirem ao sistema.

\begin{abstract}
Neste contexto em que vários países enfrentavam fragilidades econômicas, a ideologia neoliberal despontou, estimulando a reforma dos Estados nacionais por meio de ajustes fiscais, redução do aparato estatal, desregulação, descentralização de suas atividades e redução de políticas sociais concorrendo, assim, para a configuração do Estado "mínimo"- para, dessa forma, reerguer o sistema capitalista. Com efeito, o Estado deixou de ser provedor para assumir a função de regulador das políticas públicas. (OLIVEIRA, et. al., 2013, p. 630).
\end{abstract}

Ser somente regulador era muito mais rentável ao Estado do que ser provedor. Enquanto "Estado mínimo" no financiamento e fornecimento de serviços sociais, podia tornar-se máximo no crescimento econômico e na regulação sem, contudo, ter muitos gastos. No caso da educação superior, porém, o Estado precisava manter cautela. Era desse setor que saía parte de sua mão de obra, necessitando, portanto, manter-se presente. Logo, a solução encontrada foi substituir o controle detalhado a priori por supervisão e controle a posteriori por meio de avaliações. (POLIDORI et. al., 2011).

Observa-se, no entanto, que se o que levou os Estados a se reconfigurarem de tal maneira foi o fator econômico, em nome do qual se poderia solapar os direitos sociais, qualquer tipo de avaliação usada em prol da regulação deveria também corroborar o reerguimento e desenvolvimento da economia. Se a avaliação não o fizesse, estaria contradizendo o posicionamento adotado pelo próprio Estado. Esse, como visto no item anterior, já se rendia ao capital ao subsidiar a expansão da educação privada a partir da segmentação dos tipos de IES permitidas, logo imbricar o fator econômico no contexto avaliativo seria previsível. A qualidade educacional, no que se relaciona à finalidade das avaliações da educação superior do país, está também, diante desse contexto, subordinada ao fator econômico. E quando se enfoca no interesse de organismos internacionais pelas avaliações, esse pressuposto fica ainda mais pungente.

Os organismos internacionais, que exercem influência teórica, técnica ou econômica sob o Brasil e outros países, resolveram zelar pela garantia de políticas avaliativas favoráveis à expansão capitalista dos países. Tudo era válido e necessário quando em prol do capital. Assim, o Banco Mundial (BM) $)^{35}$, a Cooperação e Desenvolvimento Econômico $(\mathrm{OCDE})^{36}$, a

\footnotetext{
35 O BM, juntamente com o Fundo Monetário Internacional (FMI) foi criado em 1944, durante a Conferência de Bretton Woods, nos Estados Unidos, a qual discutia, sobretudo, a reconstrução dos países devastados na Segunda Guerra Mundial.
} 
Organização das Nações Unidas para a Educação, a Ciência e a Cultura (Unesco) ${ }^{37}$, entre outros, ainda que tivessem suas particularidades que os diferenciavam, caminhavam rumo a mesma finalidade - a manutenção do capitalismo. Em 1992, por exemplo, a Comisión Económica para América Latina y el Caribe (CEPAL), em parceria com o Escritório Regional de Educação da Unesco (Orealc), produziu e publicou o documento intitulado Educación y conocimiento: eje de la transformación productiva con equidad. Nele, afirmam, conforme a síntese de Ottone (1993), a necessidade de se repensar

[...] o papel do Estado, abandonando o enfoque de administração burocrática dirigista e centralizadora, geradora antes de rotinas que de inovações, em prol de uma visão que potencie a orientação estratégica, a regulação à distância, o impulso das autonomias e a avaliação dos resultados. (p.13).

Subtende-se que para o documento em questão o Estado provedor de direitos sociais não gera inovações. $\mathrm{O}$ que as gera é aquele que regula à distância, que deixa as IES terem mais autonomia, e que se mostra presente somente averiguando os resultados que essas empresas educacionais mostrariam via avaliações. Foco em resultados, no entanto, é o mesmo que reduzir a qualidade a um percentual ou média, por exemplo.

A OCDE, organização da qual o Brasil é key partner (parceiro-chave) ${ }^{38}$, entre outros documentos, publicou em 1999 o Quality and Internationalisation in Higher Education. Nele, percebe-se que ao Estado caberia assegurar que as IES estejam oferecendo uma educação adequada ao objetivo da nova configuração estatal (o crescimento econômico); que essas o façam com o maior custo-benefício possível; e que estejam produzindo os egressos desejados (mão de obra competente para o mercado), como se pode observar no trecho a seguir:

With the increased funds comes an increased concern on the part of government to be reassured on three counts. Firstly, are the higher education institutions explicitly planning and organizing to produce the graduates required by society, i. e. are their objectives appropriate? Secondly, is the money being spent well, i. e. are the higher education institutions operating efficiently? Thirdly, are the higher education institutions producing the

36 A OCDE foi criada em 1961 no contexto do Plano Marshall, o qual visava à reconstrução dos países devastados na Segunda Guerra Mundial.

37 A UNESCO está vinculada à Organização das Nações Unidas (ONU) e foi criada em 1945 numa conferência realizada em Londres para esse fim.

38 A condição de parceiro-chave permite ao Brasil participar de Comitês da Organização e de inúmeras áreas de trabalho. 
desired graduates, i. e. are they operating effectively? ${ }^{39}$. (OECD, 1999, p. 29).

A avaliação, para esse organismo, seguindo os três enquadramentos aludidos na citação destacada, deve oferecer informações sobre eficiência e eficácia do sistema educacional, o que se daria especialmente pela maior valorização dos dados quantificáveis e passíveis de ranqueamento. ${ }^{40}$ (ASSIS, 2008). Qualidade, nesse contexto, além de ser reduzida a um percentual, também é equiparada aos conceitos de "melhor" ou "pior", que tem os rankings como subsidiadores.

O BM, por sua vez, divulgou em 1995 o documento La enseñanza superior: las lecciones derivadas de la experiencia, cuja versão em inglês havia sido publicada em 1994. Talvez um dos documentos mais claros a respeito do posicionamento dos organismos internacionais sobre as políticas de educação superior, o "texto é transparente. Os empréstimos estão condicionados a adoção pelo país tomador das diretrizes do organismo.” (LEHER, 2003, p. 11). Em outras palavras, se algum país necessitasse de apoio financeiro do Banco para a educação, precisava, pois, seguir suas prescrições. E quais eram elas?

O documento, por exemplo, propunha o pagamento de alguma quantia pelo aluno das instituições públicas, visto que, em sua visão, as “instituciones pueden aceptar más estudiantes si éstos pagan derechos de matrícula por cursos específicos" ${ }^{\text {"1 }}$ (BANCO MUNDIAL, 1995, p. 58). Propunha ainda o incentivo a se ter um tipo de instituição que ele denominaria como universidade de ensino (sem pesquisa), a ser instaurada nos países em desenvolvimento, já que, na perspectiva do Banco,

[...] debido a los gastos elevados, de personal e instalaciones que significa la enseñanza y la investigación de posgrado en el campo de las ciencias experimentales, es mejor concentrar la investigación y la formación

39 Com o incremento de recursos [públicos para a educação superior] vem um incremento relativo ao papel do governo em garantir três enquadramentos. Em primeiro lugar, estão as IES claramente planejadas e organizadas para produzir os graduados requeridos pela sociedade, isto é, são seus objetivos apropriados? Em segundo lugar, o dinheiro esta sendo bem gasto, isto é, estão as IES operando de forma eficiente? E, em terceiro lugar, estão as IES produzindo os egressos desejados, isto é, estão eles operando eficientemente? (Tradução de Bertolin, 2009).

40 Valorizando os indicadores quantificáveis e passíveis de ranqueamento, a OCDE divulgou em 2014 o relatório Panorama da Educação de 2014 da OCDE. Amplamente expandido na mídia, esse destaca que: (i) o Brasil é o penúltimo entre 35 pesquisados no que tange a investimento por aluno na educação básica e superior; e (ii) o investimento na educação superior é 4 vezes maior que o da educação básica. (VIEIRA; RANGEL, 2014).

${ }^{41}$ Instituições podem aceitar mais estudantes se estes pagarem em determinados cursos a matrícula que tinham por direito. (Tradução nossa). 
científica avanzada sólo en aquellas instituciones en que se puedan financiar adecuadamente los programas. ${ }^{42}$ (BANCO MUNDIAL, 1995, p. 80-81).

Não suficiente, o BM defendia também que os recursos repassados dos governos às IES deveriam estar condicionados ao desempenho dessas nas avaliações, tudo em nome de assegurar a eficiência e de aumentar o desenvolvimento econômico. (LEHER, 2003).

Em documentos mais recentes, como o Higher Education in developing countries: peril and promise, publicado em 2004, a lógica do BM é a mesma e continua fortalecendo a importância do papel de supervisão do Estado e o uso de avaliações com foco nos resultados. (DIAS SOBRINHO, 2010). Sendo assim, no contexto das proposições desse organismo, qualidade também se converte literalmente em moeda de troca; em poder econômico. As avaliações, com foco nos resultados, deveriam ser claramente voltadas ao aumento da eficiência e eficácia do sistema educativo com poucos gastos.

Em suma, o BM e os demais organismos exemplificados prescreveram: (i) a substituição do Estado provedor pelo regulador, (ii) o uso dos resultados de avaliações para a regulação estatal e (iii) a implementação de avaliações com foco nos resultados e na diminuição de gastos. Interessa à economia que as avaliações mostrem, por exemplo, se aquela instituição $\mathrm{X}$ é melhor que a $\mathrm{Y}$, ou se os egressos da $\mathrm{Y}$ estão mais preparados para o mercado que os da $\mathrm{X}$; e que o expressem por meio de números passíveis de ranqueamento. Qualidade seria, praticamente, um poder de afirmação da IES diante do mercado educacional.

É como se o pensamento empresarial de competitividade, custo-benefício e contenção de gastos tivesse, na visão dos organismos, que ser transferido às políticas públicas de educação para que a economia se desenvolvesse. Uma abordagem avaliativa, contudo, que siga esse viés, visa somente à regulação do Estado e não à autorregulação de cada IES; se preocupa com o resultado avaliativo e não com o processo e todas as particularidades inerentes a ele em cada caso; e pretende gerar diferenciação das instituições por meio de rankings dos resultados avaliativos e não auxílio para que essas repensem suas práticas. Tal abordagem, definitivamente, não inclui uma avaliação como a autoavaliação institucional e não enxerga a qualidade como algo amplo, processual ou que sofre influência das particularidades de cada instituição, por exemplo. Está-se diante, assim, de duas tendências avaliativas totalmente distintas, concorrentes e que encerram níveis diferentes de qualidade. Sobre elas não há na literatura nomenclaturas únicas.

\footnotetext{
${ }^{42}$ Devido aos elevados gastos, com pessoal e instalação que requerem o ensino a investigação na pós-graduação na área das ciências experimentais, é melhor concentrar a investigação e a formação científica avançada só naquelas instituições em que se possa financiar adequadamente os programas. (Tradução nossa).
} 
A primeira abordagem assume várias tipologias, sendo conhecida, dentre outras, como avaliação centralizadora, funcional, contábil, operacional, de resultados; enfim, de cunho pragmatista. A segunda, por sua vez, recebe fundamentalmente as designações de avaliação formativa, participativa, efetividade social e científica; enfim, de cunho emancipatório. (OLIVEIRA; FONSECA; AMARAL, 2006, p. 78).

Independente do nome que se quiser atribuir a esses dois tipos avaliativos, ambos são totalmente distintos um do outro, encerrando, por conseguinte, concepções de qualidade divergentes. A avaliação centralizadora, como mostra Dias Sobrinho (2004), tem função técnico-burocrático-economicista e é sustentada pela epistemologia objetivista, enquanto a dita formativa tem função ético-política e é aportada pela epistemologia subjetivista.

Os seguidores da epistemologia objetivista são, geralmente, (i) pessoas adeptas à ideia de que é possível tratar a realidade sem contaminação ideológica, (ii) governantes, (iii) responsáveis pela regulação, (iv) organismos multilaterais e (v) setores universitários a serviço do mercado. A avaliação fundada nessa epistemologia, chamada usualmente de avaliação controladora, pretende prestar informações objetivas, científicas, claras e incontestáveis, além de úteis na orientação ao mercado consumidor e aos governos. Caracteriza-se por ser eminentemente técnica, trazer procedimentos quantitativos e passíveis de rankings e por controlar a qualidade dos serviços e produtos educacionais. Ademais, justifica-se pela ideia de que os estudantes são clientes e que, por o serem, têm o direito de saber se estão contratando a educação com melhor custo-benefício, com bons professores, serviços, etc. (DIAS SOBRINHO, 2004).

Enquanto isso, os seguidores da epistemologia subjetivista são, geralmente, pessoas que defendem os valores históricos da universidade referenciada à sociedade. A avaliação fundamentada nessa perspectiva é também chamada, entre outras maneiras, de avaliação formativa; e essa objetiva promover, entre outras questões, a autonomia da comunidade acadêmica, compreender e melhorar as IES e formar cidadãos com as competências éticas, científicas e políticas requeridas pela sociedade. Caracteriza-se pela construção de processos sociais de comunicação baseados na autonomia, pelo uso de múltiplos enfoques na abordagem da educação e por ser participativa e democrática. Finalmente, justifica-se pela ideia de que se a realidade é complexa, dinâmica, aberta e polissêmica, em educação não existe uma verdade única, senão relativa e dependente das experiências humanas, o que exigiria o uso de abordagens qualitativas e intuitivas na avaliação. (DIAS SOBRINHO, 2004).

Acredita-se que ambas as práticas avaliativas que dão legitimidade a essas duas epistemologias buscam aquilo que seria qualidade. Mas a primeira reduz qualidade a um 
resultado, aproximando-se mais ao reducionismo no qual o mercado se concentra; enquanto a última a entende como um processo e aproxima-se, com isso, àquela instituição idealizada, sobre a qual se falou no item anterior. A avaliação, nesse último caso, se constitui em um processo de autorreflexão e autogestão com vistas a transformações benéficas às IES, além de enfatizar a autoavaliação, com base nos princípios de participação e de gestão democrática. (VERHINE; MONTEIRO DE FREITAS, 2012).

Qual tipo avaliativo, no entanto, é utilizado como aporte para a regulação do Estado? Em um processo regulatório em que esse se vale de avaliação controladora, a IES torna-se um agente passivo no processo avaliativo, apenas recebendo prescrições e adequando-se. Já em um processo em que o Estado baseia-se em uma avaliação formativa, a IES passa a ser coautora do processo regulatório ao imprimir suas próprias reflexões e planos de mudanças. $\mathrm{O}$ conceito de qualidade em uma avaliação formativa não provê somente do Estado, mas da própria IES, a qual, a partir de suas referências e particularidades, também se impõe como coautora do processo avaliativo. Esse tipo de IES cujos agentes refletem, criticam e se posicionam sobre suas próprias práticas não é, contudo, como já visto, o preferido do Estado.

É sabido que a avaliação precisa ter função formativa e, consequentemente, fornecer informações para tomadas de decisões em vários níveis, como o da instituição, do curso, da família ou do indivíduo, servindo para muito além da regulação. (DIAS SOBRINHO, 2003). A proposta da autoavaliação, objeto desta pesquisa, é um exemplo de avaliação não reduzida a aspectos regulatórios, por exemplo, no entanto, essa, ainda que citada no PNE (2014-2024), por exemplo, é colocada como coadjuvante do processo avaliativo. A partir dela, a IES e todos seus agentes poderiam se conhecer melhor, descobrir suas fragilidades e pontos fortes, trabalhar conjuntamente em prol de melhorias, etc. No entanto, na prática, às vezes as políticas avaliativas empreendidas dão preferência a focar em informações mensuráveis, comparáveis e padronizadas, esvaziando-se formativamente, classificando-se como controladoras e servindo tão somente à regulação.

É preciso que se leve em conta que a avaliação controladora caracteriza-se pelo foco em resultados numéricos, passíveis de comparação e distinção, os quais servirão exclusivamente aos processos regulatórios de autorização, reconhecimento e renovação de reconhecimento de curso, por exemplo. Enquanto isso, a avaliação formativa não tem limites; essa, especialmente por meio da autoavaliação, dá espaço a que a IES reflita sobre suas dificuldades e metas sem que necessariamente o intuito seja prestar conta ao Estado.

Enquanto a função regulatória do Estado, porém, for posta em prática como uma extensão do mercado - seguindo seu mesmo pensamento - as avaliações centralizadoras serão 
priorizadas. E nesse caso cabe a sempre atual metáfora de Bourdieu (1998), onde a mão esquerda do Estado, responsável por interesses sociais mais amplos, dependia da mão direita, responsável pelos interesses econômicos, tinha livre arbítrio. Quando se trata de oferecer educação superior pública e de qualidade, a mão direita do Estado, "obcecada com a questão do equilíbrio financeiro, ignora o que faz a mão esquerda, confrontada com as consequências sociais frequentemente muito dispendiosas das "economias orçamentárias."” (p. 14).

Para Oliveira et. al. (2013, p 634), "a regulação deveria ser um momento posterior à avaliação e, ao mesmo tempo, dependente dela", lendo-se "avaliação" como aquela de perspectiva formativa. No entanto, o que fica visível quando se pensa a questão tendo como ótica a história, a economia mundial e o Estado capitalista, é que as medidas regulatórias seriam vistas como mais importantes, a exemplo da própria inclinação dos organismos internacionais, anteriormente aludida. Depreende-se disso que o mais importante para o sistema é o fechamento ou não de uma instituição, o reconhecimento ou não de um curso, etc. - medidas que reduzem a qualidade a aspectos puramente regulatórios.

O fato é que nunca houve no discurso mundial uma intenção de equilíbrio entre regulação e avaliação formativa quando se cogitou usar a avaliação como ferramenta básica do processo de regulação da educação superior. Para começar, a avaliação do tipo formativa nem apareceu no discurso do modelo capitalista de Estado que surgiu com a substituição do welfare state. Ademais, nos discursos dos organismos internacionais, que tanta influência exercem sob as economias do mundo e, claro, do Brasil, a preocupação com os anseios, dificuldades e particularidades de cada IES são anulados.

O Sinaes, em sua proposta, visa "assegurar uma coerência, tanto conceitual quanto procedimental, buscando a articulação de natureza formativa, voltada para a perspectiva de autoconhecimento das instituições com as funções de natureza regulatória próprias do Estado". (RIBEIRO, 2012, p. 307). No entanto, diante de um Estado em que a lógica mercadológica vem sendo cada vez mais priorizada, é difícil assegurar a viabilidade formativa dessa política e toda a amplitude que a qualidade ganharia a partir dela. O modelo capitalista de Estado tem claramente a questão econômica como pano de fundo, sendo grande o desafio de se contrariar isso. Como se poderá visualizar no quadro de Afonso (2013), a seguir, o Estado capitalista/avaliador, vem sendo implantado em fases, sendo que em cada uma se caminha rumo a uma aproximação maior à lógica mercadológica reinante. 
Quadro 2: Comparação das diferentes fases do Estado avaliador

\begin{tabular}{|c|c|c|}
\hline $\begin{array}{l}\text { Estado-avaliador } \\
\left(1^{\mathrm{a}} \text { fase, anos de }\right. \\
1980 / 1990)\end{array}$ & $\begin{array}{c}\text { Estado-avaliador } \\
\left(2^{\text {a }} \text { fase, final dos anos de }\right. \\
1990 \text { e atuais anos } 2000 . . .)\end{array}$ & $\begin{array}{l}\text { Pós-Estado-avaliador } \\
\text { (antevisão com base em } \\
\text { alguns indicadores) }\end{array}$ \\
\hline $\begin{array}{l}\text { Expressiva autonomia } \\
\text { relativa do Estado-nação na } \\
\text { definição de políticas } \\
\text { públicas. Prioridade ao } \\
\text { controle social por parte do } \\
\text { Estado. Estreita vinculação } \\
\text { ideológica neoliberal e } \\
\text { neoconservadora com as } \\
\text { políticas avaliativas e de } \\
\text { accountability. Incremento } \\
\text { de avaliações externas } \\
\text { nacionais em larga escala } \\
\text { (provas de aferição, exames } \\
\text { nacionais, exames } \\
\text { estaduais...). Maior } \\
\text { incidência nos níveis de } \\
\text { ensino básico e secundário } \\
\text { (fundamental e médio). } \\
\text { Participação naño } \\
\text { sistemática em avaliações } \\
\text { comparativas nace } \\
\text { internacionais. Emergência } \\
\text { de formas de avaliação } \\
\text { externa do ensino superior } \\
\text { em muitos países sem essa } \\
\text { tradição. Empréstimo e } \\
\text { aprendizagem como } \\
\text { principais mecanismos de } \\
\text { transferência de políticas, } \\
\text { nomeadamente no que diz } \\
\text { respeito a países centro- } \\
\text { europeus e norte- } \\
\text { americanos, estando, no } \\
\text { entanto, mais presentes os } \\
\text { mecanismos de imposição } \\
\text { para países do Sul onde o } \\
\text { Fundo Monetário } \\
\text { Internacional (FMI)/ Banco } \\
\text { Mundial e o "Consenso de } \\
\text { Washington" têm sido mais } \\
\text { precoces e ortodoxos. }\end{array}$ & $\begin{array}{l}\text { Retração crescente da } \\
\text { autonomia relativa do Estado- } \\
\text { nação e maior protagonismo de } \\
\text { instâncias internacionais e } \\
\text { transnacionais (União } \\
\text { Europeia, OCDE, Banco } \\
\text { Mundial...). Prioridade do } \\
\text { Estado ao processo de } \\
\text { acumulação. Expansão dos } \\
\text { processos de globalização } \\
\text { (cultural, política e } \\
\text { econômica...). Consenso } \\
\text { transideológico em relação à } \\
\text { necessidade de políticas de } \\
\text { avaliação. Incidência nos } \\
\text { níveis de ensino básico e } \\
\text { secundário (fundamental e } \\
\text { médio) e maior diversificação } \\
\text { e precocidade das avaliações } \\
\text { externas nacionais. } \\
\text { Consolidação de agências } \\
\text { autônomas ou de direito } \\
\text { privado para a avaliação e } \\
\text { acreditação do ensino superior } \\
\text { nacional. Protagonismo de } \\
\text { agências internacionais para a } \\
\text { qualidade, como a European } \\
\text { Association for Quality } \\
\text { Assurance in Higher Education } \\
\text { (ENQA) em contexto europeu. } \\
\text { Regulação pelo conhecimento, } \\
\text { definção de indicadores e } \\
\text { adesão a políticas baseadas em } \\
\text { resultados e evidências. } \\
\text { Participação mais frequente e } \\
\text { regular em avaliações } \\
\text { comparativas internacionais, } \\
\text { com indução de rankings } \\
\text { (PISA da OCDE, por } \\
\text { exemplo). Harmonizaçãa, } \\
\text { disseminação,estandardização, } \\
\text { imposição, entre outros, como } \\
\text { mecanismos de transferência } \\
\text { de políticas. }\end{array}$ & 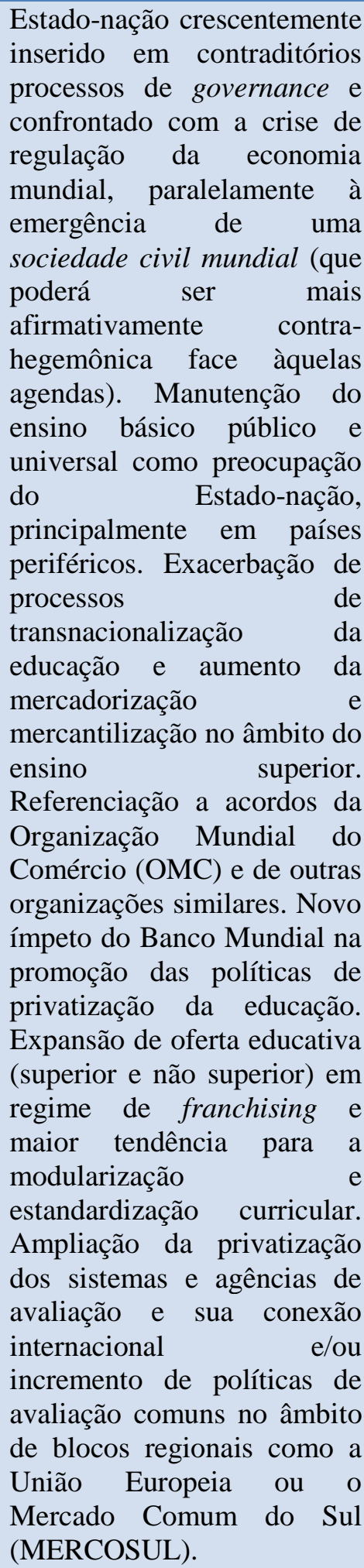 \\
\hline
\end{tabular}

Fonte: AFONSO (2013, p. 278). 
Como se pôde perceber com base no quadro 2, para Afonso (2013) o desenvolvimento do Estado capitalista/avaliador seria marcado por momentos distintos caracterizados pelas novas e cada vez mais modernas estratégias de avaliação de que o Estado se vale para cumprir seu papel de regulador. Por sua vez, ora essas avaliações são criadas pelos estados nacionais, ainda que às vezes influenciadas por organismos internacionais; ora - e cada vez mais -, são criadas por conexões internacionais, mas sempre visando a maior competitividade entre os mercados e o maior lucro. A terceira fase, especificamente, a qual, para o autor, seria a que está pouco a pouco entrando em cena, não foge à regra, e

[...] quer justamente acentuar a ideia de que, para muito além das agendas nacionais e dos efeitos externos da globalização sobre os diferentes países, o que está em curso é uma estratégia de exacerbação e diversificação de lógicas neoliberais de transnacionalização da educação, com ênfase na privatização, mercadorização e mercantilização [...]. Esta etapa pós-Estadoavaliador referencia-se, não exclusiva, mas principalmente, ao ensino superior e não significa, antes pelo contrário, que a avaliação saia da ordem do dia, mas, antes, que fugirá cada vez mais do âmbito do Estado nacional (sobretudo em países periféricos e semiperiféricos), como, aliás, começou a ser mais evidente já na segunda fase do Estado-avaliador. (p. 280).

Diante desse panorama apresentado por Afonso (2013) fica mais perceptível que a avaliação formativa - e inserida nela, a autoavaliação -, realmente não parece ter vez em um modelo capitalista de Estado tal qual o que se vem querendo implementar. Ela encontra-se de fato explanada na proposta do Sinaes, mas contradiz o próprio contexto histórico em que está inserida.

Regular é importante e essencial para que a educação superior expanda assegurando-se padrões mínimos de qualidade, no entanto, o modelo de regulação, contextualizado neste item, e o de expansão, no item anterior, deveria subverter-se um pouco à lógica neoliberal de crescimento e priorizar a avaliação do tipo formativa. A autoavaliação, objeto dessa pesquisa, pode, por exemplo, contribuir muito com a qualidade das instituições, pois pressupõe que elas mesmas reflitam e ajam sob suas debilidades. Porém, tudo indica que o verdadeiramente desejável ao Estado é uma qualidade cada vez mais reduzida a aspectos quantitativos e ranqueáveis, o que se encaixa, sobremaneira, ao modelo de avaliação controladora.

No Brasil, conforme Barroso (2006), a regulação da educação superior divide-se em vários níveis, e aparentemente em nenhum deles se foge ao foco no crescimento econômico. A regulação transnacional foi o nome que o autor atribuiu à regulação exercida por organismos internacionais. E no Brasil, assim como em outros países, esse nível regulatório faz-se perceptível quando pensada a influência dos organismos internacionais, a exemplo dos 
aludidos anteriormente. Esses exerceram seu poder regulatório internacional para fazer com que os Estados, inclusive o brasileiro, utilizassem na regulação avaliações com foco nos resultados e não na autonomia das IES, na autogestão, na reflexão participativa, entre outras características tão presentes na autoavaliação.

Um segundo nível de regulação para o autor seria a representada por uma avaliação sistêmica, como é o caso do Sinaes. Essa, segundo Barroso (2006, p. 50), é representada por autoridades públicas (neste caso o Estado e a sua administração), as quais "exercem a coordenação, o controlo e a influência sobre o sistema educativo, orientando através de normas, injunções e constrangimentos o contexto da acção dos diferentes actores sociais e seus resultados.”. Observe que até o "constrangimento" de instituições é válido nesse nível, o que mais uma vez não caracteriza uma lógica formativa, muito menos uma autoavaliação institucional.

Um terceiro nível da regulação, por sua vez, seria a metarregulação, a qual consiste na ação do Estado como "regulador das regulações". Esse nível permite ao Estado "não só equilibrar a acção das diversas forças em presença, mas também continuar a garantir a orientação global e a transformação do próprio sistema." (BARROSO, 2006, p. 65). Nesse caso, quando o Estado, por exemplo, por meio de pesquisas empreendidas pelo MEC/Inep/Conaes, ou por outras vias, acompanha a implementação de determinado momento avaliativo do Sinaes, está exercendo a metarregulação. Salienta-se, no entanto, que como se verá no capítulo três, historicamente as IES não recebem feedback de seus relatórios de autoavaliação, o que vem a endossar a ideia de que a qualidade priorizada é aquela reduzida a percentuais e ranqueamentos.

Finalmente, chegando ao último nível de regulação trazido por Barroso (2006), tem-se a microrregulação local, que "remete para um complexo jogo de estratégias, negociações e acções, de vários actores, pelo qual as normas, injunções e constrangimentos da regulação nacional são (re)ajustadas localmente, muitas vezes de modo não intencional.” (p. 56). Em outras palavras, é o modo como as medidas regulatórias realizadas a nível macro, a exemplo, pelo Sinaes, são recebidas e ajustadas no contexto de cada instituição de educação superior pelos seus agentes (professores, estudantes, secretários, gestão, etc.). E neste último fica a dúvida: se a medida regulatória a ser implementada não for, na prática, baseada em uma avaliação formativa, não levando, por conseguinte, em consideração as particularidades e posicionamentos da própria IES, qual o sentido da implementação? Cumprir o que o Estado diz ser o padrão mínimo de qualidade? Aquele que historicamente vem tendo como balizador o capital? 
Infelizmente, ainda que regular não devesse ser sinônimo de controlar, o fato de seu foco historicamente ser o desenvolvimento econômico e não questões como a instituição, o aluno ou a prática educativa, por exemplo, faz com que a regulação seja confundida com controle e valha-se de avaliações controladoras.

O ideal seria que a concepção de avaliação priorizada pelo Estado regulador apontasse sempre para a linha formativa, valorizando, por conseguinte, a autoavaliação. Isso permitiria, por exemplo, que se pensasse a regulação como um momento posterior à avaliação formativa, separada desta, ainda que dela dependente. Uma vez, no entanto, que a concepção de avaliação desejada pelo Estado aponte para a linha de controle e, por que não dizer, de punição, sua interface com a regulação torna-se intensa, podendo até juntar-se os dois processos. (MENEGHEL; ROBL; SILVA, 2006). E isso é o que pode estar acontecendo, se se levar em consideração as questões históricas, políticas e econômicas dominantes.

A partir do tipo de avaliação do qual o Estado se vale no momento em que exerce seu papel regulador - se controladora ou formativa -, fica determinada, respectivamente, a qualidade esperada das IES: se aquela reduzida a um percentual ou se representante de todo um processo consciente e participativo de reflexão. A discussão empreendida neste item e no anterior mostra, contudo, que o Estado sempre foi solícito à expansão desenfreada do setor privado e pouco preocupado com a avaliação formativa e sistêmica. Por conseguinte, a educação superior no país vem sendo, historicamente, tomada como via de desenvolvimento econômico, sendo a qualidade aquele percentual mínimo, mas que já agrada ao mercado. Nesse contexto, o que interessa é a expansão capitalista e o controle, ficando a avaliação da educação superior em vigência com o grande desafio de fomentar algo sobre cujo Estado e Sinaes não entram em consenso: a qualidade.

\subsection{QUALIDADE DA EDUCAÇÃO SUPERIOR: TENSÕES À VISTA}

Não existe um conceito determinado para qualidade em educação superior. O que existe são ações que convergem para algo que pode ser considerado qualidade por uns, mas não por outros. A avaliação, nesse contexto, se converge em um catalisador dessas várias ações, visto que a partir do momento em que o Estado absteve-se da obrigatoriedade de prover a educação superior, passou às políticas avaliativas o encargo de controlar a expansão com vistas a um mínimo de qualidade. 
O Sinaes, especificamente, diz-se uma avaliação do tipo formativa, a qual, entre outras prerrogativas, deveria levar bastante em consideração o processo de autoavaliação. De que forma, no entanto, esse vem catalisando, na sua prática, as concepções divergentes sobre qualidade é assunto extenso, que transpassará os capítulos 2 e 3, seguintes, aparecendo tanto na legislação relacionada, como na fala dos entrevistados, indiretamente. Cabe ainda aqui neste capítulo, no entanto, visualizar as tentativas existentes de se contextualizar aquilo que parece tão difícil de tornar-se consensual: a qualidade.

Como visto, a configuração estatal que vem sendo implementada no Brasil capitalista - regula a educação superior por meio de leis, decretos, planos e avaliações. Porém, a meta a ser atingida por essa configuração estatal aqui presente não parece, como visto, ser a qualidade educacional, em sua amplitude, senão a expansão livre de IES privadas e aumento do controle. Ao priorizar isso, o Estado brasileiro corrobora a subsunção da avaliação do tipo formativa e parece não enxergar que a simples produção em massa de egressos para o mercado de trabalho é limitadora aos discentes e a toda comunidade acadêmica.

\footnotetext{
Por um lado, a expansão rápida de profissionais graduados [em algumas áreas específicas] favorece imediatamente ao capital industrial, posto que cria um exército de reserva que tende a rebaixar os salários dessa categoria profissional. Por outro lado, se esse exército é constituído por graduados sem as devidas qualificações, isto é, qualidades requeridas pelo processo produtivo, a médio e longo prazo, o capital industrial poderá encontrar sérias dificuldades em seu processo produtivo. (RODRIGUES, 2007, p. 7).
}

Não é possível prever de onde vai surgir uma consciência de mudança em relação à finalidade da educação superior; e nem se o Sinaes terá condições, a médio e longo prazo, de fomentar uma qualidade que, ainda que sem definição consensual, distancie-se do reducionismo que a prioridade na expansão e no controle imprime. O único certo é que o conceito de qualidade em educação é polissêmico (GADOTTI, 2013; DOURADO; OLIVEIRA, 2009; SOUSA, 2009; BURLAMAQUI, 2008). E isso já indica que, apesar de décadas fazendo avaliação da educação superior e criando políticas para o setor, conceituar qualidade nunca foi, na prática, prioridade.

Acredita-se que, diante da dificuldade de defini-la, o que resta é o vivenciado, o qual, em suma, traz consigo um verdadeiro dilema conceitual. Pirsig (1974, p. 179), por sua vez, ilustra bem esse dilema. Para o autor, a qualidade é aquilo que 
[...] uno sabe lo que es, pero uno no sabe bien lo que es. Eso es contradictorio. Pero cuando uno trata de expresar lo que es la calidad, aparte de las cosas que la tienen, ;todo se hace confuso! No hay nada que se pueda decir claramente. Si uno no puede decir qué es "calidad", cómo se sabe entonces "lo que es", de ese modo, para todos los propósitos prácticos, la calidad no existe". Pero para todos los propósitos prácticos la calidad sí existe. Si no, ¿en qué basamos nuestras calificaciones? ¿Por qué otro motivo la gente gastaría fortunas en adquirir algunos bienes y tiraría otros a la basura? Obviamente, algunas cosas son "mejores que otras" pero ¿qué es esto de "ser mejores"?... Así, uno se da vueltas y vueltas, girando ruedas mentales, sin encontrar un sustrato para afirmarse "¿Qué diablos es la calidad $?^{43}$

Antes de, como diz Pirsing (1974), dar "voltas e voltas, girando rodas mentais" a fim de tentar compreender qualidade, vale ter em mente que uma definição comum não será encontrada. Faz-se importante percorrer, no entanto, o que se tem escrito a respeito, pois isso é mais um fator determinante para se compreender o lugar que a avaliação formativa e, especificamente, a autoavaliação ocupa em tempos onde a regulação com vistas ao controle é que vem sendo priorizada. Do ponto de vista etimológico do termo, qualidade, de acordo com Sousa (2009),

[...] corresponde à propriedade, atributo ou condição das coisas ou das pessoas, capazes de distingui-las das outras e/ou de lhes determinar a natureza. Por sua vez, o termo latino qualitas significa essência e designa o que é mais importante, o que determina algo. Assim, a qualidade indica a centralidade das coisas e dos seres, aquilo que essencialmente caracteriza algo e o marca. Em razão da complexidade que esse conceito envolve, refletir a respeito dele significa lidar com o contraditório, reconhecendo que a educação, no mundo atual, recorre constantemente a ele, identificando-o como seu principal objetivo. (p. 245).

Para começar a lidar com o contraditório, aludido por Sousa (2009), recorre-se a alguns referenciais teóricos na tentativa de perscrutar as tentativas de conceituação de qualidade. Um deles é o que organismos internacionais prescreveram sobre o tema, visto que esses não poderiam isentar-se de falar do assunto se desejavam tanto que as reformas dos Estados nacionais fossem favoráveis ao capitalismo. Outro referencial, por sua vez, é o que a

\footnotetext{
${ }^{43}$ [...] a pessoa sabe o que é, mas a pessoa, ao mesmo tempo, não sabe bem o que é. Isso é contraditório. E ainda quando alguém trata de expressar o que é a qualidade, para além das coisas que possuem qualidade, tudo fica confuso! Não há nada que se possa dizer claramente. Se a pessoa não pode assegurar o que é "qualidade", como se sabe, então, "o que ela é", desse modo, para todos os propósitos práticos, a qualidade não existe. Mas para todos os propósitos práticos a qualidade sim existe. Caso contrário, em que basearíamos nossas qualificações? Por qual outro motivo as pessoas gastariam fortunas para adquirir alguns bens e jogaria outros no lixo? Obviamente, algumas coisas são melhores que outras, mas o que é isso de "ser melhor"? Assim, a pessoa dá voltas e voltas, girando rodas mentais, sem encontrar algo que sirva de base para se afirmar "que diabos é a qualidade?". (Tradução nossa).
} 
academia vem dizendo sobre o mesmo, pois entre os pesquisadores já se tornou quase um jargão as palavras "educação de qualidade".

Entre os organismos que têm mais influência sob as políticas de educação superior do Brasil, sobressai-se, como já visto, o BM, a OCDE e a Unesco. Em 1995 o BM elaborou o documento La enseñanza superior: las lecciones derivadas de la experiencia, o qual, entre outras questões, relacionou a qualidade à eficácia. Essa seria alcançada, de acordo com o organismo, quando as IES contem com (i) egressos que tiveram boa educação básica, (ii) docentes competentes e motivados, (iii) boas instalações, (iv) acordos internacionais entre instituições, (v) orientações do setor produtivo privado ocupando funções dentro das instituições (vi) e uma cultura de avaliação que foque no que é ensinado aos alunos, conforme se pode perceber no trecho a seguir:

Con el objeto de evaluar la enseñanza impartida por el cuerpo docente, los métodos empleados con mayor frecuencia dependen de las calificaciones de los estudiantes, los análisis de los esquemas de los cursos, las evaluaciones a cargo de los jefes de los departamentos y los colegas y los premios a docentes. (BANCO MUNDIAL, 1995, p. 78 - 79). ${ }^{44}$

Chama atenção, portanto, o aspecto de cobrança que uma avaliação com vistas à qualidade deveria ter, de acordo com o Banco Mundial. O objetivo da avaliação seria verificar se os professores estão ensinando "adequadamente"; e se estes estiverem, ganhariam prêmios. Qualidade aqui prevê a punição de uns, que não ganhariam gratificações, e o destaque de outros, que ganhariam. A avaliação, especificamente, só poderia ser uma prova, visto que o que importaria era a calificación do estudante, ou seja, sua nota.

Em 2000, o Banco também publicou o documento Higher Education in developing countries: peril and promise (BANCO MUNDIAL, 2000), o qual, de acordo com Dias Sobrinho (2010) veio a fortalecer o estabelecimento de políticas de avaliação da Educação Superior em todo mundo, ao defender, entre outras questões, a importância do papel de supervisão do Estado.

Com esses documentos, o BM, além de valorizar, sobretudo, a regulação, associou a qualidade aos resultados do rendimento do estudante e do ensino - características pontuais das quais a avaliação deveria tomar conta. Qualidade aqui é entendida como algo focal, e não amplo. A baixa qualidade da educação nos países em desenvolvimento, por sua vez, é

\footnotetext{
${ }^{44}$ Com o objetivo de avaliar o ensino empreendido pelo corpo docente, os métodos empregados com maior frequência dependem da nota dos estudantes, da análise do currículo dos cursos, as avaliações a cargo dos chefes de departamentos e dos colegas y as premiações aos docentes. (Tradução nossa).
} 
atribuída à "má administração dos recursos destinados a essa área e não à quantidade insuficiente desses recursos". (IVASHITA; NOVAK; BERTOLLETI, 2009, p. 9.360). É como se países como o Brasil, não soubessem custear uma educação de qualidade e devessem, portanto, deixar isso a cargo do setor privado, limitando-se a regular a educação por meio de avaliações que avaliariam principalmente o rendimento do discente e o ensino oferecido.

Já a $\mathrm{OCDE}^{45}$ segue direcionamentos análogos aos do Banco Mundial. A questão da gestão financeira de recursos e do uso de avaliações pelo Estado volta aqui a ser fator determinante para o alcance da qualidade. Para esse organismo, as IES devem formar profissionais competentes para o mercado de trabalho e sem gastarem muito. E quanto à avaliação, essa deve gerar resultados passíveis de ranqueamento para que a população (consumidores) saiba quais seriam as melhores e as piores instituições. Essas questões, nas próprias palavras do organismo, "concerns have led to new interpretations of the concept of quality."46 (ORGANISATION ECONOMIC CO-OPERATION AND DEVELOPMENT, 1999, p. 29). Qualidade aqui, complementarmente ao que postula o BM, relaciona-se a ideia de que, assim como qualquer empresa do mercado, na educação existem empresas melhores e outras piores, sendo preciso demarcá-las.

Finalmente, outro organismo que, devido a sua influência na educação superior no mundo, vale ser citado é a Unesco. Para esse, uma educação superior de qualidade está totalmente atrelada à avaliação, mas àquela mais próxima da perspectiva de sistema avaliativo. Para a Unesco, uma

[...] autoevaluación interna y un examen externo realizados con transparencia por expertos independientes, en lo posible especializados en lo internacional, son esenciales para la mejora de la calidad. Deberían crearse instancias nacionales independientes, y definirse normas comparativas de calidad, reconocidas en el plano internacional. Con miras a tener en cuenta la diversidad y evitar la uniformidad, debería prestarse la atención debida a las particularidades de los contextos institucional, nacional y regional. (ORGANIZAÇÃO DAS NAÇÕES UNIDAS PARA A EDUCAÇÃ̃, A CIÊNCIA E A CULTURA, 1998, p. 27). ${ }^{47}$

\footnotetext{
${ }^{45}$ A OCDE vem destacando-se entre os demais organismos internacionais devido à constante ampliação de sua influência sobre países membros ou não. Além da educação, essa organização vem regulando nos últimos vinte anos políticas de energia, telecomunicações e transportes, por exemplo. (LEMOS, 2014).

46 [...] têm conduzido para novas interpretações do conceito de qualidade." (Tradução de Bertolin, 2009).

${ }^{47}$ [...] autoavaliação interna e um exame externo realizados com transparência por especialistas independentes, se possível especializados na temática internacional, são essenciais para a melhoria da qualidade. Dever-se-ia criar instancias nacionais independentes, e definir-se normas comparativas de qualidade, reconhecidas internacionalmente. Com o objetivo de levar em conta a diversidade e evitar a uniformidade, se deveria prestar a devida atenção às particularidades dos contextos: institucional, nacional e regional. (Tradução nossa).
} 
Assim, como os outros organismos aqui citados, a Unesco também considera que o fomento da qualidade se dá por meio de avaliações, contudo, ao contrário dos demais, parece não reduzir a qualidade somente a características pontuais retiradas de exames aplicados aos estudantes. Aqui se chega a falar também de se dever utilizar a autoavaliação. Não suficiente, a Unesco demonstra, em outro documento, preocupação em conceituar a qualidade levando em conta não só fatores econômicos, mas fatores humanos, com respeito ao contexto particular de cada IES. Segundo esse organismo,

[...] dois princípios caracterizam grande parte das tentativas de definir qualidade em educação. $\mathrm{O}$ primeiro identifica o desenvolvimento cognitivo dos alunos como o principal objetivo explícito de todos os sistemas educacionais. Consequentemente, o sucesso dos sistemas em realizar este objetivo é um dos indicadores de sua qualidade. O segundo enfatiza o papel da educação na promoção de valores e atitudes de cidadania responsável e no provimento do desenvolvimento criativo e emocional. (ORGANIZAÇÃO DAS NAÇÕES UNIDAS PARA A EDUCAÇÃO, A CIÊNCIA E A CULTURA, 2005, p. 17).

Ainda que não declarado pela Organização, o segundo princípio de qualidade enfatizado não é captado ou fomentado por um exame, mas por uma avaliação formativa, como a autoavaliação, por exemplo. Em suma, com exceção da Unesco - que pelo menos reconhece a possibilidade de que qualidade não seja só a nota de um estudante em uma prova -, os organismos internacionais em geral propagam uma ideia de qualidade em educação superior reducionista.

Para Bertolin (2009), quem tenta trazer, a partir da observação de ações circundantes, definições para a qualidade da educação superior, uma perspectiva economicista de qualidade permeia as prerrogativas dos organismos internacionais, bem como do setor privado e do governamental. Nessa perspectiva, para se alcançar a qualidade da educação é preciso levar em conta a equidade, mas entendendo-a como igualdade de oportunidades, que nada mais é do que tratar igual os desiguais. Encarar a equidade nesse sentido não é preocupar-se "com aquilo que é justo, mas com a manutenção do sistema econômico e da "ordem social", já que com isto esperam potencializar a capacidade de trabalho dos pobres e seu poder de consumo, atendendo duplamente ao mercado.”. (LIMA; RODRÍGUEZ, 2008, p. 67).

Sob tal perspectiva, avaliações do tipo centralizadoras, as quais devem focar na eficiência do sistema, entendendo eficiência como gestão financeira, são as mais convenientes. Isso se dá, porque, em 
[...] tempos de neoliberalismo, a visão de que a educação superior tem como missão principal o crescimento da economia e a preparação dos indivíduos para o mercado de trabalho está em grande evidência. De acordo com essa lógica, além de orientarem seus serviços para os interesses econômicos e formar egressos especialmente para o mercado de trabalho, as instituições também devem atuar da forma mais eficiente e eficaz possível para que seus objetivos sejam alcançados com o menor custo e a máxima rapidez possível, ou seja, trata-se de uma visão amplamente economicista, que se refere a uma perspectiva prioritariamente instrumental e produtivista da educação superior. (BERTOLIN, 2009, p. 134).

Tal lógica, se tomada como parâmetro de definição de qualidade, dá suporte a avaliações ligadas especificamente ao controle estatal, as quais nada teriam de formativas. Essas fomentariam qualidade, mas a da visão economicista, a qual se distancia muito do previsto para a autoavaliação. Em uma perspectiva formativa, a qualidade passa pelo dinamismo da rotina de cada IES, com suas contradições, pontos de vistas diversos, situações específicas, etc. Tais elementos são mais bem visualizados por meio da avaliação institucional e, especificamente, da autoavaliação, visto que essa última representa o olhar da IES sob ela mesma; contudo, a avaliação formativa vem a se desenvolver naturalmente quando visões mais amplas de qualidade se sobressaem.

Duas outras perspectivas trazidas por Bertolin (2009), que caracterizam as práticas dos organismos internacionais e outras instâncias, são a pluralista e a de equidade. Essas, na visão da autora desta pesquisa, podem viabilizar mais facilmente a autoavaliação. A visão pluralista seria a defendida por algumas instituições de educação superior, pela Unesco, pela União Europeia e por alguns governos que não se renderam totalmente ao neoliberalismo. Nela, além da questão econômica, abarcam-se outros aspectos, tais como desenvolvimento cultural, social e democrático dos países e sociedades de forma sustentável. Ademais, ela pressupõe a não prioridade a uma visão única para a educação superior, considerando, portanto, as especificidades e diferenças locais, institucionais e regionais.

A visão de equidade, por sua vez, seria, conforme o mesmo autor, a defendida também pela Unesco, bem como por algumas instituições do setor educativo. Ela pode englobar diversos aspectos, "como a igualdade de oportunidades do acesso em relação aos grupos sociais, às etnias, às diferentes regiões de um país ou mesmo ao nível de homogeneidade da educação proporcionada pelas diferentes instituições educacionais.” (BERTOLIN, 2009, p. 142). Em síntese, é uma perspectiva que considera que ter qualidade é ter inclusão, o que se daria pela observância e contorno das necessidades específicas de cada grupo social e, logo, por meio de tratamento diferenciado àqueles grupos historicamente desiguais. 
Ambas as perspectivas podem dar abertura à avaliação formativa, como a autoavaliação. Uma Comissão Própria de Avaliação, em um contexto pluralista, pode, por exemplo, identificar que a comunidade acadêmica está carente de contato com questões culturais, decidindo sugerir à gestão ações que visem o desenvolvimento cultural. Da mesma forma, a CPA, sob uma visão de equidade, pode perceber que determinado grupo de discentes de sua instituição precisa de assistência para o pagamento da matrícula ou para o transporte público, por exemplo. Assim, sempre e quando há amplitude na concepção de qualidade adotada, dicotomias como: melhor e pior ou nota da instituição X e da instituição $Y$, são ultrapassadas, dando espaço a especificidades e, logo, à autoavaliação. No quadro 3, a seguir, observa-se sinteticamente as três perspectivas explanadas:

Quadro 3: Visões de qualidade em educação superior

\begin{tabular}{|c|c|c|l|c|}
\hline $\begin{array}{c}\text { Visão de } \\
\text { qualidade }\end{array}$ & $\begin{array}{c}\text { Termos } \\
\text { associados }\end{array}$ & $\begin{array}{c}\text { Grupos de } \\
\text { interesse }\end{array}$ & \multicolumn{1}{|c|}{ Propósitos da ES } \\
\hline $\begin{array}{c}\text { Visão } \\
\text { economicista }\end{array}$ & $\begin{array}{c}\text { Empregabilidade } \\
\text { e Eficiência }\end{array}$ & $\begin{array}{c}\text { Setor privado, } \\
\text { OCDE e setor } \\
\text { governamental }\end{array}$ & $\begin{array}{l}\text { Enfase nos aspectos de potencialização do } \\
\text { crescimento da economia e da } \\
\text { empregabilidade }\end{array}$ \\
\hline Visão pluralista & $\begin{array}{c}\text { Diferenciação, } \\
\text { Pertinência e } \\
\text { Relevância }\end{array}$ & $\begin{array}{c}\text { Unesco, União } \\
\text { Europeia e setor } \\
\text { educativo }\end{array}$ & $\begin{array}{l}\text { Diversidade de aspectos relevantes } \\
\text { (economia, sociocultural, democracia, } \\
\text { etc.) com enfase na emergência das } \\
\text { especificidades locais }\end{array}$ \\
\hline $\begin{array}{c}\text { Visão de } \\
\text { equidade }\end{array}$ & Equidade & $\begin{array}{c}\text { Unesco e setor } \\
\text { educativo }\end{array}$ & $\begin{array}{l}\text { Enffase nos aspectos de contribuição para } \\
\text { a coesão social }\end{array}$ \\
\hline
\end{tabular}

Fonte: Bertolin (2007).

Além de Bertolin (2009; 2007), e adentrando agora mais à visão dos acadêmicos em relação à qualidade da educação superior, tem-se Morosini (2014). Essa também tenta categorizar possíveis conceitos para o que seria a qualidade da educação superior. Segundo a autora, os conceitos emergentes para a qualidade poderiam se dividir em qualidade isomórfica e qualidade da equidade.

A qualidade isomórfica seria a influenciada pela internacionalização global, a qual, na visão da autora em questão, considera a avaliação como o fim e não como o meio para atingir a qualidade. Nessa perspectiva, o resultado seria o que mais se sobressai em um processo avaliativo, por isso ser também chamada de qualidade de modelo único. Em tempos de modernização e racionalidade, a comparação e a busca de standards seria o que, nessa visão, poderia ser definido como qualidade.

Se a autoavaliação, como se verá detalhadamente no capítulo seguinte, não gera percentuais passíveis de ranking, e tampouco tem foco no resultado, essa perspectiva de 
qualidade isomórfica não a leva em consideração. A autoavaliação se dá no processo, na pesquisa, na discussão mútua entre agentes de dentro e fora da IES, etc, logo, talvez a outra perspectiva apresentada pela autora a levaria mais em conta.

Essa outra, por sua vez, seria a qualidade da equidade, emergente de sociedades com grandes diferenças sociais, como o Brasil. Nessa perspectiva, a qualidade está para além de um modelo único, pois leva em consideração a necessidade de tratamento diferenciado para quem é diferenciado. A avaliação aqui abarca tanto estudos quantitativos como qualitativos.

Contraditoriamente, mesmo o Brasil estando entre os países em desenvolvimento, ele tende muito mais a aderir à qualidade isomórfica que à qualidade da equidade (MOROSINI, 2014); ou, ainda, mais uma visão economicista de qualidade, que uma visão pluralista ou de equidade (BERTOLIN, 2007). Depreende-se isso do fato de que, como visto nos itens anterior, o Brasil vir demonstrando, a exemplo de sua legislação e de sua postura controladora, estar curvando-se explicitamente às demandas do mercado.

Mais um conceito importante no que tange à qualidade da educação superior é o de qualidade acadêmica, social e educativa, elaborado por Demo (1994). A qualidade acadêmica seria "a capacidade de produção original de conhecimento, da qual depende intrinsecamente a docência" (p. 35). Ao professor caberia transmitir um conhecimento que ele próprio tenha construído por meio, especialmente, de suas atividades de pesquisa.

A qualidade social seria "a capacidade de identificação comunitária, local e regional, bem como com relação ao problema do desenvolvimento. [...] Trata-se de colocar à universidade a necessidade de ser consciência teórica e prática do desenvolvimento" (DEMO, 1994, p. 38). Em outras palavras, esse conceito significa atrelar a teoria à prática por meio do contato do estudante com a realidade social, o que poderia se dar por meio de estágio ou de participação em projetos de extensão, por exemplo.

A qualidade educativa, por fim, refere-se a "questão política, porquanto, educação é principalmente a formação da cidadania, o cultivo da capacidade de autopromoção, a impregnação da identidade cultural e comunitária, a instrumentação da participação política". (DEMO, 1994, p. 40). É a capacidade da instituição de educação superior esforçar-se por uma formação plena do cidadão, quem seria consciente das questões sociais, econômicas e políticas as quais estaria inserido.

Sem distanciar-se da tríade conceitual de Demo (1994), Sander (1995) também apresenta um conceito de qualidade em educação. Para esse último, a qualidade educacional baseia-se "na desconstrução e reconstrução dos conhecimentos acumulados historicamente, 
constituindo-se uma tentativa de síntese teórica da experiência latino-americana de administração no contexto internacional" (p. 40).

Ao trabalhar o conceito de qualidade na administração da educação, Sander (1995) cria o que ele chama de Paradigma Multidimensional, o qual é constituído de quatro dimensões analíticas: econômica, pedagógica, política e cultural. A cada dimensão, por sua vez, corresponde o respectivo critério de desempenho administrativo da IES: eficiência, eficácia, efetividade e relevância, os quais, juntos, imprimiriam a qualidade institucional.

O primeiro, a eficiência, é aquele que entende que "é o critério econômico que revela a capacidade administrativa de produzir o máximo de resultados com o mínimo de recursos, energia e tempo" (p. 43). Por conseguinte, esse se relaciona à gestão financeira da IES. Já a eficácia "é o critério institucional que revela a capacidade administrativa para alcançar as metas estabelecidas ou os resultados propostos" (p. 46). Logo, o que está em jogo aqui é a capacidade da IES no que se relaciona à consecução de objetivos traçados. A efetividade, por sua vez, "é o critério político que reflete a capacidade administrativa para satisfazer as demandas concretas feitas pela comunidade externa" (p. 47). Por conseguinte, refere-se à capacidade de a instituição responder às necessidades da sociedade. Finalmente, a relevância, por sua vez, "é o critério cultural que mede o desempenho administrativo em termos de importância, significação, pertinência e valor" (p. 50). E esse último critério refere-se ao empenho da IES na melhoria do desenvolvimento humano e da qualidade de vida da comunidade acadêmica.

Outro conceito de qualidade em educação é o de Scriven (1991), focado nos atributos de valor e mérito. Para ele, um objeto educacional, no caso, a própria instituição de educação superior, tem valor quando os seus recursos estão sendo bem aplicados para atender suas próprias necessidades; e tem mérito quando faz bem o que se propõe a fazer. Nesse conceito, qualidade relaciona-se ao cumprimento da proposta institucional da IES, do que se infere que não haveria um modelo único de qualidade ou de instituição de educação superior.

Todas as concepções de qualidade de Scriven (1991), bem como dos demais teóricos e também dos organismos internacionais, apesar de apresentarem focos diferentes, são fruto da observação e análise que esses fizeram do movimento histórico da educação superior mundial. Não são manuais a serem adotados, mas fontes que ajudam a se perceber o contexto em que educação e avaliação estão inseridas. Todas as concepções podem acontecer mutuamente, em sua plenitude ou em algum aspecto, sendo a educação superior e as avaliações dessa, portanto, locais de embate. 
Observa-se, contudo, que, apesar da existência de várias concepções de qualidade, algumas apontam mais à linha do controle, sendo, pois, reducionistas. Seus focos são na gestão orçamentária, desempenho dos estudantes, diferenciação de IES e até em recompensa a professores, por exemplo. Outras, por sua vez, têm uma visão mais ampla para o conceito de qualidade, considerando que as instituições não pertencem a um modelo único, que os estudantes têm suas particularidades e necessidades próprias, e que a instituição, independente do que recebe como prescrição, possui sua própria missão institucional.

As concepções de qualidade existentes vêm refletindo, assim, os embates no campo da educação superior explanados nos tópicos anteriores deste capítulo: (i) instituição de educação superior que visa a formação de cidadãos críticos $v s$ instituição de educação superior que visa a formação de mão de obra para o mercado; e (ii) avaliação formativa $v s$ avaliação controladora. Uma avaliação formativa buscaria induzir que as IES se preocupassem, entre outras questões, com uma formação de cidadãos críticos, o que pressupõe uma perspectiva de qualidade ampla. Já uma avaliação controladora se contentaria em zelar pela manutenção de instituições com foco na formação para o mercado, considerando, portanto, um critério de qualidade reducionista.

A partir do momento em que o Estado capitalista, visando ao lucro, tende a ser controlador, mas, ao mesmo tempo, institui um sistema avaliativo cuja proposta é formativa e precursora do empoderamento das IES via autoavaliação, só se pode esperar tensões à vista. $\mathrm{O}$ Sinaes e a autoavaliação, especificamente, como se verá nos capítulos seguintes, pretende induzir aquilo que está sendo aqui colocado como "qualidade ampla", contudo, só a prática e o tempo mostrarão a viabilidade disso. Lutar contra aquilo historicamente constituído - no caso, a "necessidade" de controle e o foco mercadológico - pressupõe duas possibilidades: (i) dar novos rumos à história da avaliação e educação superior, ou (ii) render-se, apresentando mais do mesmo.

\subsection{SÍNTESE PARCIAL}

A concretização de uma política avaliativa pode ser vista como uma variável totalmente dependente do contexto social, econômico, histórico, político e cultural no qual a avaliação se desenvolve. Por esse motivo, neste capítulo, priorizou-se um percurso que levasse o leitor a refletir sobre como a questão da qualidade em educação superior relaciona- 
se (i) à finalidade das instituições de educação superior; e (ii) à finalidade da avaliação da educação superior; para, por fim, explanar as tentativas de conceituação do termo.

A partir desse percurso, percebeu-se que no contexto histórico, político e econômico brasileiro atual os limites e possibilidades da autoavaliação estão condicionados à maneira como o Estado capitalista vem conduzindo a expansão da educação superior. Nesse sentido, conforme se verá, detalhadamente, no próximo capítulo, tem-se que o Sinaes, em seu projeto, pretendeu fortalecer a autonomia das IES e considerar as particularidades locais por meio da implementação de um sistema avaliativo formativo, em que se destaca a autoavaliação. No entanto, na prática, isso não vem mostrando-se ser algo tão fácil de materializar-se.

Viu-se na discussão que há uma lógica neoliberal de abertura ao privado, a qual influencia com grande intensidade as políticas educacionais e que dá centralidade à avaliação controladora. Essa lógica impulsionou a corrida pelo desenvolvimento econômico a partir da transformação da educação superior em mercadoria, o que refletiu até mesmo na subsunção de práticas avaliativas como a autoavaliação. O importante no contexto vivenciado, e explanado neste capítulo, é a manutenção do setor privado; e a avaliação aparece como uma maneira de o Estado permitir o crescimento desse sem que, no entanto, perdesse o controle sob a educação.

Nesse sentido, dar voz às IES, incentivarem-nas a serem coautoras do Estado no processo avaliativo, e fazer os agentes educacionais refletirem sobre suas práticas, limitações e metas seria romper com a própria prioridade estatal historicamente instaurada. Por conseguinte, a autoavaliação se converte em arena de equalização de embates difíceis de resolver.

Mesmo nos governos de Lula (2003-2010) e no primeiro mandato do de Dilma (20112014), em que se percebe um investimento mais significativo do Estado na educação superior pública, o setor privado continua tendo espaço e apoio para se expandir e se fortalecer das mais diversas formas, entre as quais, a incorporação de instituições menores por grupos educacionais maiores. Isso, somado ao histórico de legislações anteriores a esses governos, bem como ao PNE (2014-2024), vigente, trazem incertezas sobre até que ponto o Sinaes conseguiria, verdadeiramente, implantar uma avaliação de cunho formativo e dar o devido valor à autoavaliação.

Em conformidade ao que se espera de um Estado capitalista, os documentos oficiais brasileiros referentes à educação superior mostraram o aval da política pública educativa aos processos de flexibilização e descentralização da educação. Com isso, a qualidade educacional interessante parecia ser aquela da visão do mercado - aqui denominada como 
"reducionista" -, para a qual, práticas avaliativas centralizadoras, produtoras de competitividade e rankings era suficiente.

Aparentemente, se esqueceu por um longo período, o qual ainda está em curso, que à avaliação não cabia distinguir para o mercado consumidor (estudantes e empresas) as instituições "boas" das "ruins". O fomento à competitividade entre IES e à diferenciação entre egressos da instituição $\mathrm{X}$ e da $\mathrm{Y}$ não gera qualidade. $\mathrm{O}$ ideal seria haver um momento de regulação (caracterizado por atos de autorização, reconhecimento, renovação de reconhecimento de cursos e credenciamento/recredenciamento de instituições) e um momento de avaliação formativa, o qual tanto auxiliaria nos dados necessários às medidas regulatórias como promoveria a autonomia institucional e a qualidade em uma perspectiva ampla.

Tudo indica que há, no entanto, um receio ao poder da avaliação formativa, visto que a valorização dessa, provavelmente, mexeria nas estruturas do Estado capitalista. É que a despeito da emergência de conceitos para se tentar explicar as propriedades da qualidade em educação superior, como os destacados no item 1.4, as IES tendem a se adequar ao que as avaliações propagam como qualidade. Por conseguinte, produzir, por meio de autoavaliação institucional, a emergência de sujeitos críticos, que refletem sobre suas práticas e tentam construir uma instituição que não tenha seu foco voltado ao mercado, seria andar na direção contrária do que se considera adequado à expansão capitalista.

Parece não se querer compreender que uma instituição de educação superior voltada à formação integral do sujeito pode formar também profissionais qualificados ao mercado; e que uma avaliação formativa aos moldes do Sinaes e, especificamente, da autoavaliação não atrapalha o desenvolvimento econômico do país. Porém, essa resistência torna-se mais compreensível quando se entende que qualquer mudança exigiria ao mercado da educação privada mais do que ele, comodamente, vem tendo que dar.

Por décadas se subsidiou a expansão privada de instituições das quais se cobrava menos do que das classificadas como universidade. Concomitantemente, foram valorizadas práticas de regulação que, quando isoladas, excluíam a possibilidade de uma avaliação formativa e só davam espaço ao controle estatal. Consequentemente, se há no Brasil uma cultura de avaliação, vis-à-vis essas estarem presentes nas políticas da educação superior desde a década de 1980, não se pode dizer o mesmo sobre se ter uma cultura de avaliação formativa com vistas a uma qualidade ampla. O Sinaes, ou qualquer política avaliativa, conta com a disposição dos agentes envolvidos, e com o tempo para subsidiar mudanças, pois qualquer resistência é, em certa medida, justificada pelas práticas do próprio Estado. 
A autoavaliação é um processo recente, empreendido de forma obrigatória somente a partir do Sinaes. Inserida no contexto histórico político, aqui levantado, e ainda sendo algo relativamente novo no contexto da educação superior, poderá enfrentar muitos obstáculos até se afirmar. O esforço, então, de reconhecer o papel da avaliação formativa e especificamente da autoavaliação na indução e no reconhecimento da qualidade da educação superior brasileira é algo que contribui com a implementação da autoavaliação; e não se esgota neste capítulo, continuando a se afirmar em toda a pesquisa.

$\mathrm{Na}$ continuidade, então, procura-se entender a posição que a autoavaliação ocupa dentro do Sinaes e de uma instituição de educação superior - a UnB -, primeiramente, a partir do levantamento das ações do Estado capitalista nas políticas de avaliação da educação. O Sinaes é fruto de uma política de avaliação que já vem se consolidando desde a década de 1980 - quando das primeiras iniciativas avaliativas -, por isso um retorno à trajetória da política de avaliação da educação superior brasileira faz-se necessário e ainda vem a demonstrar o reconhecimento da importância de se dar atenção às partes do processo para se chegar à necessária visão global da autoavaliação na UnB. No próximo capítulo, portanto, levanta-se a reflexão sobre as experiências de avaliação que já ocorreram no Brasil até a institucionalização do Sinaes, detendo-se mais nesse último e, especificamente, na autoavaliação. 


\section{CAPÍtUlo 2: POLÍTICAS DE AVALIAÇÃO DA EDUCAÇÃO SUPERIOR BRASILEIRA: AS IDAS E VINDAS DAS AVALIAÇÕES FORMATIVA E CONTROLADORA}

\subsection{INTRODUÇÃO}

A temática deste estudo - a autoavaliação proposta pelo Sistema Nacional de Avaliação da Educação Superior -, está inserida no campo das políticas públicas de avaliação. Consequentemente, é adequada a explicação de alguns modelos de avaliação anteriores ao Sinaes, mas importantes para se entender a implantação dele e especificamente do objeto deste estudo. É que, propositalmente ou não, todo desenvolvimento passa por um instantâneo movimento de olhar para o passado com vistas ao futuro:

\footnotetext{
Na sua interpretação do mundo, os adeptos da dialéctica postulam: primeiro, todos os objectos, processos e fenómenos são reciprocamente ligados, determinados e dependentes um dos outros; segundo, todos se encontram num processo infinito de movimento e desenvolvimento. Nada pode existir no mundo fora desta ligação universal, fora do movimento e do desenvolvimento. O desenvolvimento é concebido como processo e resultado da acumulação das mudanças quantitativas e da sua passagem para as qualitativas; como transformação qualitativa dos objectos e fenômenos em outros; como destruição do que é caduco e velho e aparecimento, configuração e consolidação do que é novo (KRAPÍVINE, 1986, p. 22).
}

Assim, dialeticamente, ou, em outras palavras, de forma processual e dinâmica (PAULO NETTO, 2011), a política do Sinaes foi se constituindo e adquirindo novas configurações. Num primeiro momento, representou a síntese bem construída das discussões empreendidas entre os anos de 1980 a 1990; e atualmente traz a incorporação de novos elementos que têm desencadeado movimentos ou de descontinuidade a avanços adquiridos ou de contradições em relação as suas concepções originárias. (RODRIGUES, 2015).

A proposta do Sinaese teria a avaliação institucional e, logo, a autoavaliação, como o guia e elemento principal, sendo o pilar mais representativo do aspecto formativo idealizado para a avaliação. Ademais, o Sistema, como um todo, se pretendia: (i) conceitual e metodologicamente coerente; (ii) incentivador do autoconhecimento e emancipação das IES; e (iii) garantidor de uma articulação dialógica entre a regulação - própria do Estado - e a avaliação formativa. Contudo, os movimentos que perpassaram os antecedentes históricos da 
avaliação da educação superior, a concepção e a implementação do Sinaes deram outros contornos a essa política avaliativa e à autoavaliação - objeto deste estudo.

Em um plano ideal, o Sinaes contaria com um momento de autoavaliação, o qual estaria integrado à avaliação externa, e mediante o qual se discutiriam os indicadores de todos os componentes do sistema avaliativo, de forma dialógica, fundada numa cultura formativa de avaliação e com vistas à melhoria da qualidade institucional em uma perspectiva ampla, conforme dito no capítulo anterior. Os relatórios de autoavaliação produzidos pelas CPA, mais que levantar as deficiências ou valorizar as qualidades da instituição, seriam construídos a partir do envolvimento de toda a comunidade acadêmica e subsidiariam mudanças na gestão da IES. "Quanto aos problemas e carências, além da verificação e da constatação, é importante identificar as suas causalidades, explicitar as possibilidades reais para a superação e estabelecer as ações adequadas e os meios para a transformação desejada.” (BRASIL/CEA, 2003, p. 71). No movimento de implementação da política, no entanto, essas ideias se perderam em parte, o que, acredita-se, se deve às próprias condições históricas e políticas na qual estavam emersas.

Dessa forma, neste capítulo será apresentada uma retrospectiva das políticas de avaliação da educação superior desde a década de 1980 até os tempos atuais, com destaque para a autoavaliação. Nessa retrospectiva, as ações do Estado capitalista continuarão sendo tomadas como pano de fundo, porém, com o diferencial de que se adentrará nas inclinações que cada governo demonstrou a uma avaliação do tipo formativa ou do tipo controladora.

Em consonância a isso, o capítulo conta com duas partes complementares. Na parte 2.2 Antecedentes históricos da avaliação da educação superior brasileira, se retomam as políticas avaliativas de educação superior do Estado brasileiro das décadas de 1980 e 1990 até imediatamente antes da institucionalização do Sinaes, as quais pertencem a medidas políticas do fim do governo militar, do governo José Sarney, do Fernando Collor, Itamar Franco e Fernando Henrique Cardoso, respectivamente. Já na parte 2.3 Concepção e implementação do Sistema Nacional de Avaliação da Educação Superior - os empasses e contradições do processo, se esmiúça esse sistema avaliativo, originado no governo de Luís Inácio Lula da Silva e em continuidade no governo da presidenta Dilma Rousseff, em sua proposta de origem - no tópico Concepção do Sinaes -; e na sua reconfiguração iniciada no segundo mandado do presidente Lula (2007-2010), com as mudanças na legislação e entraves encontrados na realidade - no tópico Implementação do Sinaes: mudanças e entraves. 


\subsection{ANTECEDENTES HISTÓRICOS DA AVALIAÇÃO DA EDUCAÇÃO SUPERIOR BRASILEIRA}

O Sistema Nacional de Avaliação da Educação Superior - Sinaes - apresenta uma proposta na qual se salienta a necessidade de se "construir uma outra lógica, com um outro sentido filosófico, ético e político: que a regulação não se esgote em si mesma, e, principalmente, articulada à avaliação educativa propriamente dita, seja também uma prática formativa e construtiva” (BRASIL/Inep, 2009, p. 95-96). Infere-se dessa declaração que se a política avaliativa atual se viu na necessidade de "construir uma nova lógica" seria porque a lógica avaliativa anteriormente usada já não era cabível. Logo, torna-se necessário uma volta às políticas avaliativas anteriores. Assim, se entenderá contra que modelo de avaliação a proposta do Sinaes se posiciona, mesmo porque já se viu na introdução e no capítulo anterior que o controle sempre permeou as políticas de avaliação da educação superior brasileira.

Como mostram Polidori, et. al. (2011), historicamente o Estado brasileiro ora tem criado avaliações voltadas ao controle, focadas nos resultados, geralmente mensuráveis e passíveis de serem transformados em rankings, ora tem criado avaliações de cunho formativo e emancipatório, focadas no processo avaliativo, em que pese à percepção interna das IES sobre suas próprias práticas. O germe do Sinaes encontra-se em ambos os tipos de políticas avaliativas (RODRIGUES, 2015), mas é sob uma avaliação formativa que se concentra sua proposta. Essa coloca a autoavaliação em posição de destaque, vis-à-vis considerar exatamente as percepções internas da IES - seus anseios, problemas e metas de superação.

O que se perceberá na retrospectiva histórica das políticas de avaliação da educação superior realizada neste capítulo é que esses dois tipos de avaliação revezam-se ou coexistemse. E, quando se pensa na implementação do Sinaes, o que acontece é a convivência desses dois tipos. Daí, o grande desafio, anunciado por Dias Sobrinho (2010) e citado no capítulo anterior, de se encontrar o ponto de equilíbrio entre a avaliação formativa e a regulação.

Para compreender a autoavaliação na Universidade de Brasília - meta desta pesquisa faz-se necessário identificar a postura de que o Estado capitalista se veste em cada política de avaliação por ele planejada desde a década de 1980 e ver até que ponto essas várias posturas culminaram no que é hoje o Sinaes. As primeiras iniciativas de se pensar uma avaliação sistematizada para o país datam das décadas de 1970 e 1980. Em 1976 se instituiu pela Coordenação de Aperfeiçoamento de Pessoal de Nível Superior (Capes) a política de 
avaliação da pós-graduação, a qual tinha como finalidade avaliar os cursos de mestrado e doutorado do país. Essa Coordenação declarava querer, com isso,

[...] (i) facilitar a distribuição de bolsas de estudo para mestrandos e doutorandos e orientar o investimento das agências federais na formação de recursos humanos de alto nível; (ii) subsidiar a política educacional relativa à pós-graduação e à universidade, assim como suas relações com a educação básica; (iii) regular a expansão da pós-graduação, recomendando o apoio aos cursos novos e incorporando-os progressivamente ao sistema de avaliação e acompanhamento; e (iv) credenciar esses cursos, tornando válidos, em plano nacional, os certificados por eles expedidos. (MACCARI; CORREIA LIMA; RICCIO, 2009, p. 73).

$\mathrm{Na}$ falta de um mecanismo que diagnosticasse as vantagens e os problemas dos cursos de graduação e das IES à época, isso era minimamente compensado pela avaliação da Capes. (CUNHA, 1997). Essa, ainda que com foco na pós-graduação, já avaliava de alguma forma as instituições educacionais. E além dessa contribuição indireta, salienta Rodrigues (2015, p. 134-135) que alguns elementos da política avaliativa da Capes "serviram de referências para as políticas posteriores de avaliação da educação superior [em nível de graduação], de forma especial no que diz respeito à necessidade da ação reguladora do Estado em relação à expansão dessa modalidade de educação no país.”.

Na década de 1980, por sua vez, surgem as primeiras propostas de políticas avaliativas para a graduação: o Programa de Avaliação da Reforma Universitária (Paru) e o Grupo Executivo para a Reformulação do Ensino Superior - (Geres). Já na década de 1990, surgem o Programa de Avaliação Institucional das Universidades Brasileiras (Paiub) e o Exame Nacional de Cursos (ENC), popularmente conhecido como "Provão", os quais serão contextualizados a seguir.

a) Programa de Avaliação da Reforma Universitária - Paru

A primeira proposta de política avaliativa sistemática da graduação - o Programa de Avaliação da Reforma Universitária (Paru) - foi criada em junho de 1983 por iniciativa do, 
posteriormente extinto, Conselho Federal de Educação (CFE) $)^{48}$ no final do governo militar, durante o mandato de Esther de Figueiredo Ferraz como ministra da Educação e Cultura.

A finalidade do Programa era realizar uma pesquisa de avaliação sistêmica que buscasse conhecer as reais condições em que se dava a disseminação do conhecimento nas IES isoladas - públicas e privadas - gerando diagnósticos que subsidiariam posteriores ações. (ROTHEN; BARREYRO, 2008). Por isso, o programa levava em consideração a participação de setores externos às IES, mas priorizava a participação da comunidade acadêmica, a qual deveria autoavaliar (i) a gestão das instituições de educação superior e (ii) o processo de produção e disseminação do conhecimento, por meio de aplicação de questionários. Dessa maneira, pode-se dizer que, em suma, a avaliação no Paru

[...] foi entendida como uma forma de conhecimento sobre a realidade, como uma metodologia de pesquisa que permitiria não só obter os dados, mas também permitia fazer "uma reflexão sobre a prática". Assim, o PARU, com a finalidade de realizar uma pesquisa de avaliação sistêmica, recorreu à "avaliação institucional" e considerou à "avaliação interna" como procedimento privilegiado. (ROTHEN; BARREYRO, 2008, p. 135).

O Programa era uma proposta inovadora que representava uma postura estatal aberta a uma avaliação do tipo formativa e emancipatória - tal como esse era -, e cujos resultados poderiam servir de subsídio à tomada de decisão nas IES. A ideia de avaliação formativa sistêmica do Sinaes, bem como a participação da comunidade acadêmica na efetivação da sua autoavaliação, já existia, portanto, duas décadas antes, no Paru. (RODRIGUES, 2015).

Não obstante, constatou-se no andamento do projeto dessa política três impedimentos básicos para a sua execução: “(i) falta de informações sistematizadas e os dados secundários inadequados aos objetivos; (ii) reforço aos aspectos qualitativos da questão com a consequente mudança no papel das equipes locais; (iii) mudança das atribuições do grupo gestor da pesquisa.” (DUARTE, 2013, p. 106). E isso, somado (i) ao fato da inovação trazida com essa proposta não ir ao encontro do tecnicismo que permeava o MEC à época; e (ii) "à compreensão de que a avaliação deveria ser um instrumento essencial de controle da educação superior" (GRIBOSKI, 2014, p. 115), fez com que a proposta fosse abortada.

\footnotetext{
${ }^{48}$ O Conselho Federal de Educação, instituído pela LDB nº 4.024/61, foi extinto em 1994 de uma maneira bastante peculiar. Não "houve um dispositivo específico determinando seu encerramento, mas um esvaziamento de suas funções com a transferência ao CNE de suas atribuições e competências". (NUNES; BARROSO; FERNANDES, 2011, p. 18). Esse, por sua vez, "foi instalado com a intenção de ser um órgão menos credenciador e mais avaliador, menos decisório e mais assessor e, finalmente, mais representativo do conjunto da sociedade e não apenas das corporações do segmento da educação.” (GRIBOSKI, 2014, p. 115).
} 
Diante, portanto, dessa situação, passado somente um ano de sua criação, o Programa foi desativado, em 1984, mesmo tendo sido importante na sensibilização das IES para a avaliação institucional. Ficou-se, assim, inconcluso o levantamento de dados e estagnados os estudos de caso que já vinham sendo realizados. Quanto aos membros do Paru (Edson Machado de Souza, Isaura Belloni, Orlando Pilatti e Sergio Costa Ribeiro), por sua vez, esses "comporiam posteriormente, comissões ministeriais e participariam da elaboração ou execução de outras experiências de avaliação da educação superior no país." (ROTHEN; BARREYRO, 2008, p. 136).

\section{b) Grupo Executivo para a Reformulação do Ensino Superior - Geres}

Já não mais sob um regime militar, mas durante o governo presidencial de José Sarney (1985-1990) e mandato de Marco Maciel como Ministro da Educação, o país passava por um período de crise financeira e pedagógica na educação superior. Esse era o momento em que se estreitavam as orientações neoliberais para as relações entre Estado e mercado (RODRIGUES, 2015). Exemplo disso era que, seguindo uma tendência mundial, a avaliação passava a ser percebida, naturalmente, como a maneira de controlar a qualidade e, por conseguinte, de assegurar a formação de profissionais bem preparados para o mercado de trabalho. Como medida para tal, o presidente instituiu em 1985, por meio do Decreto 91.177, de 29 de março desse ano, a Comissão Nacional para a Reforma da Educação Superior (CNRE), a qual estava incumbida de ajudar a reformar o ensino superior brasileiro. (BRASIL, 1985). Essa comissão, popularmente conhecida como Comissão dos Notáveis, era presidida por Caio Tácito e constituída por mais 24 membros notório saber ${ }^{49}$. Esses tinham

\footnotetext{
${ }^{49}$ Os membros da Comissão dos Notáveis eram: "Caio T.S P. de Vasconcelos, Presidente, membro do Conselho Federal de Educação, Amílcar Tupiassu, professor da Universidade Federal do Pará, Bolívar Lamounier, professor da USP e PUC-SP, Carlos Nelson Coutinho, Prof. das Faculdades Integradas Benett, Edmar Lisboa Bacha, Professor na PUC-RJ e presidente do IBGE, Eduardo De Lamonica Freira, Reitor da UFMT, Fernando J. Lessa Samento, Pró-reitor da UFBA, Francisco Javier Alfaya, estudante; Guiomar Namo de Mello, Professora na PUC-SP e Secretária de Educação do Município de SP, Haroldo Tavares, Empresário, ex-Diretor da Escola de Engenharia da UEM, Jair Pereira dos Santos, Ex Diretor do DIEESE, sindicalista; José Leite Lopes, Professor na UFRJ e presidente do Centro Brasileiro de Pesquisas Físicas; José Arthur Gianotti, Professor da USP e presidente do CEBRAP; Dom Lourenço de Almeida Prado, Prof. de Filosofia e Teologia no Mosteiro de São Bento, RJ, Luiz Eduardo Wanderley, Reitor da PUC de São Paulo, Marly M.M. Silva Araújo, Secretaria de Educação de MG, Paulo da Silveira Rosas, Professor da UFPe, Roberto Cardoso de Oliveira, Professor na UNICAMP, Romeu Ritter dos Reis, Presidente da Sociedade de Educação Ritter dos Reis, de Porto Alegre. Simon Schwartzmann (relator), Professor e diretor do IUPERJ, Ubiratan Borges de Macedo, membro do Conselho Federal da Cultura e professor na UFPR. Posteriormente, foi nomeado José Eduardo Campos de Oliveira Faria, assessor da Presidência do Banco Itaú.”. (ROSAS, 1985, apud. ROTHEN; BARREIRO, 2008, p. 136).
} 
heterogeneidade marcante, visto que apenas metade deles possuía efetivamente vivência universitária, enquanto os demais haviam frequentado cursos superiores em alguma época, desenvolvendo ainda, no momento, práticas muito diferentes das da vida acadêmica. (CUNHA, 1997). Apesar disso, para seguir as orientações do governo em questão, a Comissão deveria entrar em acordo.

No governo Sarney, como mostra Queiroz (2014, p. 119), duas hipóteses eram consideradas, as quais dialogam diretamente com as discussões levantadas no capítulo anterior:

(i) o crescimento acentuado e o grande número de matrículas no setor privado incorriam em perda de qualidade; (ii) a qualidade do ensino estava abalada tanto nas instituições privadas como nas públicas. No entanto, nas instituições privadas, a questão da qualidade foi advogada pela fragilidade do trabalho pedagógico, enquanto para o ensino público a razão estava no excesso de controles burocráticos, notadamente nas universidades.

Tendo em vista essas hipóteses, o Grupo, após várias discussões e até mesmo divergências, produziu um relatório, o qual foi intitulado Uma nova política para a educação superior $^{50}$. Tal documento baseou a proposta de intervenção na educação superior em sete princípios norteadores, a saber: (i) responsabilidade do poder público; (ii) adequação à realidade do país; (iii) diversidade e pluralidade; (iv) autonomia e democracia interna; (v) democratização do acesso; (vi) valorização do desempenho; e (vii) eliminação dos aspectos corporativos e cartoriais. Em suma, se apontava à necessidade de se aumentar a autonomia universitária concomitantemente a um processo externo de avaliação que se baseasse na valorização do mérito acadêmico. Isso significa que a Comissão, de acordo com as orientações do governo,

[...] compreendia que a contrapartida da autonomia universitária seria o desempenho das instituições. O controle do desempenho se daria pela avaliação efetivada pelos pares, e, a partir desta, seria criado um sistema meritrocrático que nortearia o financiamento estatal da educação superior. (ROTHEN; BARREYRO, 2008, p. 141).

O que a Comissão propunha, portanto, era que uma vez que a autonomia era vista como necessária, deveria ser concedida, mas com a garantia de que as IES autônomas teriam

\footnotetext{
${ }^{50} \mathrm{O}$ relatório foi constituído de cinco partes: i) princípios norteadores da proposta; ii) ideias gerais de reformulação; iii) sugestões de ações pontuais para operacionalização das ideias gerais; $i v$ ) declaração de voto de alguns membros da Comissão sobre aspectos pontuais de divergência com o relatório; e $v$ ) proposta de algumas ações de emergência. (BARREYRO; ROTHEN, 2008).
} 
altos padrões de qualidade no desempenho institucional. Essa garantia seria, claro, atestada por atividades de avaliação; e, a depender dos resultados dessa, o Conselho reconheceria o status universitário necessário à garantia da autonomia. (GRIBOSKI, 2014). A comunidade acadêmica, no entanto, teve receio de que, a partir dessas considerações da CNRE, medidas inapropriadas viessem prejudicar a verdadeira autônoma universitária. Logo, a mesma foi substituída pelo Grupo Executivo para a Reformulação do Ensino Superior (Geres) ${ }^{51}$, sem que tivesse tido tempo para gerar modificações no ensino superior. (QUEIROZ, 2011).

Esse novo grupo, criado em fevereiro de 1986 e formalizado pela Portaria $\mathrm{n}^{\circ} 170$, de 3 de março de 1986 (BRASIL, 1986), era formado por cinco membros. Esses, a partir da recuperação do relatório da Comissão, tinham como objetivo "implementar as mudanças propostas e colaborar no processo de avaliação institucional, visando ao estabelecimento de estratégias de controle e supervisão pelo Estado.” (GRIBOSKI, 2014, p. 117-118).

A despeito do receio que continuava constante entre as IES, as reuniões desse novo grupo culminaram em um anteprojeto de lei que retomava em parte as ideias da Comissão dos Notáveis. Os encaminhamentos que o grupo fez, no entanto, explicitavam melhor a postura estatal da época, onde reinava a preocupação com a garantia da continuidade do crescimento econômico, tal como mostrado no capítulo anterior.

A intenção do Geres fora que enquanto o setor privado de ensino tivesse sua qualidade regulada pelo próprio mercado e sua lei da oferta e procura, no setor público a necessidade de financiamento alavancasse a qualidade, sendo os resultados da avaliação o que geraria maior ou menor recurso às IES, bem como ações normativas por parte da CFE. Percebe-se que além de às IES públicas, por serem, em sua maioria, universidades, recaírem mais obrigatoriedades, se queria fazê-las trabalhar por financiamento. Em suma, e não surpreendentemente, se pretendia com o Geres incrementar a eficiência e a produtividade das instituições públicas em troca de distribuição de recursos, bem como garantir que as instituições privadas crescessem mais livremente. (ZAINKO, 2008; QUEIROZ, 2008). Tal flexibilidade da política de avaliação, demonstrada pelo documento do Geres, foi, como mostra Rodrigues (2015, p. 139),

[...] fator determinante para que as IES privadas se expandissem nos anos seguintes, em muitos casos, desprovidas de compromisso com a qualidade dos serviços oferecidos. Em um contexto em que as políticas de avaliação do

\footnotetext{
${ }^{51}$ O Grupo Executivo para a Reformulação da Educação Superior era formado por Antônio Octávio Cintra, professor do Departamento de Ciência Política da Universidade Federal de Minas Gerais; Getúlio Pereira Carvalho, secretário-geral adjunto do MEC; Paulo Elpídio Menezes Neto, ex-reitor da Universidade Federal do Ceará; Edson Machado de Souza, diretor da CAPES; Sérgio Costa Ribeiro, físico, pesquisador do LNCC/CNPq. (CUNHA, 1997, p. 25).
} 
país voltaram a atenção para as IES públicas em detrimento das privadas, abriram-se brechas para que os mais diferentes atores entrassem no cenário da educação superior privada.

Enquanto, portanto, o Paru era uma proposta avaliativa de cunho formativo e emancipador, com foco na autoavaliação e aos moldes do explicado sobre tal no capítulo anterior, o Geres, como visto, era voltado somente à regulação e controle estatal, baseando-se em indicadores de desempenho das IES. Vale dizer que o Sinaes, mais tarde, também contaria com indicadores de desempenho das instituições de educação, o que indica que tanto no Paru como no Geres "estão presentes elementos que mais tarde serão assimilados e reinterpretados pelo Sinaes". (RODRIGUES, 2015, p. 140). Mesmo condizente com o que esperava o mercado, o Geres não alcançou legitimidade e veio a ser substituído, quando do próximo governo, devido, especialmente, à pressão que a academia vinha fazendo.

\section{c) Programa de Avaliação Institucional das Universidades Brasileiras - Paiub}

Com o impeachment de Collor, Itamar Franco (1992-1995) assume a presidência da república, adotando "uma estratégia econômica que se apoia na desregulamentação, na privatização e na regulação pelo mercado" (QUEIROZ, 2014, p. 127). A política caminha, assim, cada vez mais, aos moldes daquilo que se crer ser importante para o crescimento econômico. Essa postura, como mostra Sguissardi (2013), era reflexo da adesão ideológica e política, cada vez mais nítida, "dos dirigentes e do empresariado do país a teses ultraliberais e receituários político-econômicos, como o do Consenso de Washington $^{52}$ (FMI, BM, BID,

\footnotetext{
${ }^{52}$ O Consenso de Washington é um conjunto de medidas formulado em novembro de 1989 por economistas de instituições financeiras situadas em Washington D.C., como o Fundo Monetário Internacional (FMI), o Banco Mundial e o Departamento do Tesouro dos Estados Unidos, e que se tornou a política oficial do FMI, sendo recomendado como forma de ajustamento financeiro dos países em desenvolvimento. Entre as medidas recomendadas estão: "a) equilíbrio orçamentário com redução de gastos públicos no setor de serviços sociais, abertura comercial e liberalização financeira; b) Reforma Gerencial do Aparelho do Estado, com adoção de conceitos como atividades não exclusivas do Estado e competitivas (entre estas a educação), propriedade pública não estatal e organização social; c) combate ao atual modelo universitário, supostamente seguidor do modelo humboldtiano de universidade, que associaria ensino e pesquisa (e extensão), e a adoção de diretrizes e propostas que conduziriam à máxima diferenciação institucional e a uma distinção, defendida por documentos do Banco Mundial, entre universidades de pesquisa (centros de excelência) e universidades de ensino; d) aprovação de leis e normas que apontassem na direção, seja da liberalização/flexibilização das IES, seja na adoção de um conceito de autonomia que significasse autonomia financeira e não de gestão financeira, isto é, o afastamento do Estado da manutenção exclusiva e prioritária das IES oficiais (preceito constitucional), restando-lhes o apelo a recursos financeiros complementares junto à iniciativa privada." (SGUISSARDI, 2013, p. 949-950).
} 
OMC e outros) e seu catálogo de recomendações ou imposições liberalizantes.”. (p. 949). Nenhum governo fora obrigado a aderir essa configuração, mas o fez voluntariamente; e, agora, de forma mais evidente.

Isso significa que se até então a lógica neoliberal havia entrado timidamente nas políticas brasileiras, a exemplo da tentativa de implementação do Geres, no momento em questão ela começa a ser efetivamente colocada em prática pelo Estado. E foi nesse contexto que em 1993, no mandato de Murilo de Avellar Hingel como Ministro da Educação, surge uma nova Comissão, a qual tinha como fim criar outra proposta de política de avaliação para o país.

A Comissão Nacional de Avaliação das Universidades Brasileiras, como se chamou esse novo grupo, surgiu da iniciativa voluntária da Associação das Instituições Federais do Ensino Superior (Andifes) e da Associação Brasileira de Universidades Comunitárias (Abruc). Ela foi instituída a partir da Portaria $\mathrm{n}^{\circ} 130$ de 14 de julho de 1993 (BRASIL/MEC/SESu, 1993), da Secretaria de Educação Superior (SESu), e reunia entidades importantes da educação superior de todos os segmentos institucionais ${ }^{53}$.

Esses representantes, juntos, geraram o Documento Básico - Avaliação da Universidade Brasileira: uma proposta nacional, no qual se entendia que a avaliação da educação superior não deveria ser uma prestação de contas em troca de financiamento, conforme o programa imediatamente anterior, mas algo necessário devido ao fato de a educação ser um bem público e, logo, afetar toda a sociedade. (ROTHEN; BARREYRO, 2008).

Observa-se aqui que a proposta do grupo contradizia o viés governamental da época, pois em meio a um contexto em que o Estado orientava-se pelo neoliberalismo, traz uma avaliação essencialmente pedagógica e formativa. Curiosamente, o Documento Básico não sofreu vetos; e, juntamente com as experiências isoladas e exitosas de autoavaliação - a exemplo das realizadas na UnB e na Unicamp iniciadas em 1986 e 1991, respectivamente, subsidiou, no mesmo ano, a criação do Programa de Avaliação Institucional das Universidades Brasileira (Paiub). O documento que deu origem a essa política fora intitulado

\footnotetext{
${ }^{53}$ Estavam presentes na Comissão: a Secretaria de Educação Superior, do MEC; a Associação Nacional de Instituições Federais de Ensino Superior; a Associação Brasileira de Universidades Estaduais e Municipais; a Associação de Universidades Particulares; a Associação Brasileira de Escolas Superiores Católicas; o Fórum dos Pró-Reitores de Graduação (das universidades); o Fórum dos Pró-Reitores de Extensão (idem); e o Fórum dos Pró-Reitores de Planejamento e Administração (idem). Essa comissão foi assessorada por um comitê de treze professores, pesquisadores e técnicos governamentais, no qual estavam pessoas de projeção no campo do ensino superior. (CUNHA, 1997, p. 32).
} 
PAIUB - Documento básico: uma proposta. De acordo com esse, o referido Programa previa cinco objetivos específicos:

1. impulsionar um processo criativo de auto - crítica da instituição, como evidência da vontade política de auto - avaliar-se para garantir a qualidade da ação universitária e para prestar contas à sociedade da consonância dessa ação com as demandas científicas e sociais da atualidade; 2 . conhecer, numa atitude diagnóstica, como se realizam e se inter-relacionam na Universidade as tarefas acadêmicas em suas dimensões de ensino, pesquisa, extensão e administração; 3. (re) estabelecer compromissos com a sociedade, explicitando as diretrizes de um projeto pedagógico e os fundamentos de um programa sistemático e participativo de avaliação, que permita o constante reordenamento, consolidação e/ou reformulação das ações da Universidade, mediante diferentes formas de divulgação dos resultados da avaliação e das ações dela decorrentes; 4. repensar objetivos, modos de atuação e resultados na perspectiva de uma Universidade mais consentânea com o momento histórico em que se insere, capaz de responder às modificações estruturais da sociedade brasileira; 5. estudar, propor e implementar mudanças no cotidiano das atividades acadêmicas do ensino, da pesquisa , da extensão e da gestão, contribuindo para a formulação de projetos pedagógicas e institucionais socialmente legitimados e relevantes. (BRASIL/MEC/SESu, 1993, p. 5).

Tais objetivos apontam um processo avaliativo que partia de dentro das instituições e cujos resultados retornariam a elas mesmas, fomentando tomadas de decisões por parte da gestão em prol de melhorias. Para atingir tal propósito, por sua vez, o Paiub era dividido em quatro etapas:

$\left.1^{a}\right)$ diagnóstico: construído a partir de dados quantitativos sobre o curso em análise; $2^{\mathrm{a}}$ ) avaliação interna: contemplando a autoavaliação, realizada pela comunidade acadêmica do curso; $3^{\mathrm{a}}$ ) avaliação externa: realizada pela comunidade acadêmica de várias IES, profissionais de áreas, representantes de entidades científicas e profissionais e empregadores, entre outros; $4^{\mathrm{a}}$ ) reavaliação interna: feita a partir dos resultados avaliativos produzidos, propiciando uma análise com a comunidade do curso (POLIDORI; MARINHO-ARAÚJO; BARREYRO, 2006).

De tal maneira, o Paiub instituiu de forma singular a autoavaliação institucional como etapa inicial e principal de seu processo avaliativo, a qual era seguida por uma avaliação externa realizada por comissões de especialistas. E a centralidade na autoavaliação se deu pela percepção de que as IES precisavam pensar (i) o que estão fazendo, (ii) os resultados que estão tendo e (iii) as pessoas envolvidas no processo, conforme ilustra o depoimento de um dos representantes dos pesquisadores da área entrevistados: 
O Paiub ele nasce com uma ênfase na autoavaliação, porque se acreditava, para além de se ter um sistema, que se a instituição não olha pra si mesma, não tenta compreender a si mesma dentro das diferentes atividades que desenvolve, ai a gente se pergunta: o que ela tá fazendo? Como que ela avalia o que faz? Os seus resultados... as pessoas que se envolvem em todo esse processo... para pensar sobre isso. ( $\mathrm{P} 4$, informação verbal).

Já os procedimentos teórico-metodológicos, que perpassariam todas as etapas e objetivos, bem como, especificamente, a autoavaliação, levariam em conta (i) a globalidade, (ii) a comparabilidade, (iii) o respeito à identidade institucional, (iv) a não premiação por resultados, (v) a adesão voluntária, (vi) a legitimidade e (vii) a continuidade.

Uma proposta avaliativa que é desenhada sob essas bases e valorizando esses procedimentos somente poderia revelar que "sua preocupação é pedagógica, social e direcionada para a transformação institucional. Ancorado nesses princípios, o processo avaliativo é, por si mesmo, um mecanismo de construção e melhoria de qualidade." (QUEIROZ, 2011, p. 32).

Em 1998, o Paiub foi reformulado a fim de adequar-se ao sistema de avaliação previsto no decreto $n^{\circ} 2.026 / 1996$, no $n^{\circ} 2.306 / 1997$ e à portaria $n^{\circ} 302 / 1998^{54}$ (BRASIL, 1996; 1997; 1998). Mantendo, contudo, sua essência, o Programa passou a responder oficialmente pelas avaliações individuais das IES, as quais seriam realizadas por meio de autoavaliação e avaliação externa, ambas coordenadas pela SESu. Assim, mesmo depois de reformulado, o Paiub continuava sendo representativo das concepções de educação das universidades que o deram origem. A título de exemplificação, tem-se que, conforme representante dos pesquisadores da área, a

[...] Universidade Federal do Rio Grande do Sul no marco do Paiub teve experiências muito interessantes sobre o uso dos resultados da autoavaliação. Por exemplo, eles mudaram o currículo de alguns cursos de exatas porque viam que na disciplina Cálculo os estudantes tinham problema; e isso saiu da autoavaliação da instituição. (P2, informação verbal).

O Programa, dessa maneira, não considerava os anseios de um governo que só se importava com as práticas de regulação, senão, especificamente, com as questões referentes às

\footnotetext{
${ }^{54}$ Nesta perspectiva, apesar de serem características do Paiub a adesão voluntária e o respeito à identidade institucional, o Decreto n ${ }^{\circ}$ 2.026/1996 e o Decreto no 2.306/1997, bem como a Portaria MEC n. ${ }^{\circ} 302 / 1998$ que estruturaram inicialmente o sistema nacional de avaliação da educação superior - , o alçaram a instrumento por meio do qual a avaliação de desempenho individual das IES deveria ser realizada, fazendo com que o referido Programa, em tese, passasse apenas a regular o credenciamento de instituições. (OLIVEIRA, et. al. 2013, p. 638).
} 
instituições de educação superior; mesmo assim, contraditoriamente, foi levado adiante sob o aval das instâncias governamentais.

O problema era que um Estado capitalista que não comandava a própria avaliação parecia inadmissível a alguns; e a situação acabou gerando "desconfiança por parte das instituições e sindicatos dos docentes e dos funcionários quanto à intencionalidade do governo com tal aplicação". (QUEIROZ, 2014, p. 130).

Percebe-se no Paiub, tanto devido seus objetivos como devido sua ideia de continuidade e autorreflexão por parte das IES, sua essência formativa e emancipatória. Diferentemente do Geres, o Paiub tinha o pressuposto de que as instituições de educação superior precisavam ser avaliadas considerando-se os diversos aspectos de suas atividades, no que diz respeito à missão e à gestão institucional, por exemplo. Além disso, como mostra Zainko (2008), pode-se dizer que o Paiub teve boa aceitação acadêmica devido ao fato de que com:

[...] a titularidade da avaliação nas mãos da comunidade acadêmica e a educação entendida como um bem público, o PAIUB aposta na construção de práticas avaliativas que sejam participativas, contínuas e sistemáticas, afinadas com o debate público e com a função social da educação superior no momento histórico. (p. 829).

Apesar disso, pairava uma celeuma quanto à manutenção de um programa desse tipo por parte de um Estado com objetivos divergentes. Assim, com a mudança de governo e subida de Fernando Henrique Cardoso ao cargo de Presidente da República, o Paiub, que já não tinha apoio nem incentivo do Ministério da Educação, agora passa a não se mostrar "adequado enquanto alicerce para dar os subsídios necessários ao MEC para o desempenho das funções de coordenação e controle do sistema de educação superior” (ZAINKO, 2008, p. 830), tendo tido sua verba de manutenção cancelada.

Com o começo da vigência do governo de FHC, o Paiub e, com ele, a autoavaliação, foi, literalmente, deixada "de lado para dar espaço às estratégias de avaliação da educação superior que estavam sendo apresentadas" (POLIDORI, MARINHO-ARAUJO; BARREYRO, 2006, p. 428).

Seu legado, no entanto, é incontestável. Muito da essência formativa do Programa, por exemplo, foi incorporada pelo Sinaes. Conforme Griboski (2014, p. 120), o "princípio básico do Paiub se encontrava na forma global e sistêmica em que a IES deveria ser avaliada. Nesse sentido, foi a política que mais se aproximou dos princípios do Sinaes, por valorizar a avaliação como indutora de qualidade." Ademais, foi essa política avaliativa que 
proporcionou que a avaliação formativa da educação superior no Brasil desse, oficialmente, seus primeiros passos.

Propunha a realização, nas instituições que a ele aderiram, de três momentos avaliativos: avaliação interna, avaliação externa e reavaliação. Durante sua existência o PAIUB mostrou a importância, para a realidade brasileira, da associação entre avaliação, qualidade e transformação institucional. Tal fato faz com que, ainda hoje, seja tomado como referência, até mesmo por outros países. (MENEGHEL; ROBL; SILVA, 2006, p.96).

Antes, no entanto, que a política avaliativa em vigência fosse implementada nacionalmente, fora necessário vivenciar a retomada da mão firme do Estado capitalista na educação superior do país por meio da criação do Exame Nacional de Cursos - ENC, discutido a seguir.

\section{d) Exame Nacional de Cursos - ENC}

Em 1995, no primeiro mandato do governo de FHC (1995-1998) e tendo Paulo Renato de Souza como Ministro da Educação, quem continuaria no cargo durante o segundo mandato, tem-se início uma nova política avaliativa para a educação superior. Essa política, mais do que as anteriores, viria totalmente moldada pelos ideais neoliberais que há muito já vinham influenciando os governos brasileiros. A reestruturação do papel do Estado, que agora chega a seu ápice, levou a que a educação superior fosse finalmente "definida como uma mercadoria, cumprindo, no mundo dos negócios, a satisfação das demandas produtivas do mercado nacional e transnacional." (QUEIROZ, 2014, p. 132).

Convergente com as ideias do MEC e do Estado capitalista, a Lei no 9.131, de 24 de novembro de 1995, regulamentada pela Portaria 249/96 e pelo Decreto 2.026/96, estabeleceu diretrizes à nova política de avaliação da educação superior da época, a qual em nada se assemelharia ao Paiub. Tal Lei extinguiu definitivamente o CFE, conferindo mais autoridade de supervisão ao MEC; e deliberou que se deveria "realizar avaliações periódicas das instituições e dos cursos de nível superior, fazendo uso de procedimentos e critérios abrangentes dos diversos fatores que determinam a qualidade e a eficiência das atividades de ensino, pesquisa e extensão." (BRASIL, 1995, art. $8^{\circ}$ ). Observa-se que a palavra "eficiência", tão recorrente nos discursos dos organismos internacionais citados no capítulo anterior, já 
aparece nos objetivos da Lei. Esse programa, mais do que qualquer outro, tinha, conforme Menezes (2012),

[...] como proposta central promover a regulação, controlar o ensino de graduação, controlar o rendimento dos alunos e orientar os empregadores quanto às competências e habilidades demonstradas pelos estudantes candidatos a um emprego. Além disso, propunha classificar os cursos, com o intuito de informar o mercado quanto à qualidade e também à regulação do sistema, por meio da legitimação dos processos de reconhecimento dos cursos. (p. 72).

A política em questão instaurou três ferramentas avaliativas, a saber: (i) a Avaliação das Condições de Oferta (ACO), que visava verificar as condições dos cursos de graduação para fins de autorização e reconhecimento; (ii) a visita in loco, realizada por comissões de especialistas designadas pelo MEC; e (iii) o Exame Nacional de Cursos (ENC), popularmente conhecido como "Provão".

Não havia mais vestígios da autoavaliação institucional aos moldes do Paiub e ainda, como mostra Nascimento (2008, p. 43), embora "houvesse outros instrumentos de avaliação da educação superior, a centralidade do processo de avaliação, validado pelo MEC, voltou-se para os estudantes concluintes dos cursos de graduação, por meio do ENC". O Sinaes, desde 2008, com a criação de índices (CPC e IGC), explicados no próximo tópico, tem valorizado, assim como o ENC, a prova realizada pelos estudantes, ofuscando, com isso, a totalidade do Sistema, de acordo com Rodrigues (2015).

Em suma, no ENC o que estava sendo montado com essa atitude de supervalorização da prova era um esquema de avaliação orientado exclusivamente para resultados e com forte apelo ideológico, visto que proporcionava à sociedade o poder de escolha sobre os produtos educacionais oferecidos pelas IES, à semelhança do que acontece no mercado. (RIBEIRO, 2012). No caso do Sinaes espera-se não chegar a tanto.

O ENC, ou "Provão", era basicamente um exame escrito que continha o conteúdo mínimo para cada área de formação e que media as aprendizagens dos estudantes no último ano dos cursos. Os resultados desse se sobressaiam aos demais componentes da política e subsidiavam comparações dos cursos em âmbito local, regional e nacional. Ademais, dava base ao reconhecimento de curso, credenciamento e recredenciamento de IES, além da elaboração de rankings de instituições, "evidenciando uma concepção de avaliação como controle e hierarquização, voltada para a regulação, buscando identificar os melhores e comparando os padrões de excelência.” (QUEIROZ, 2011, p. 36). 
A parte de "identificar os melhores" é algo bastante comum para o mercado. Levando em consideração que a educação superior brasileira, como visto no capítulo anterior, apresentou basicamente uma expansão privada mercantil, a possibilidade de destacar-se por meio da nota na avaliação deveria ser atrativa para a competição do setor. Contudo, de acordo com Cunha (2003, p. 51), curiosamente, "a principal oposição ao Provão proveio do setor privado, que preferiu não expor o baixo desempenho dos seus estudantes, comparativamente com os do setor público.”. A política avaliativa, então, que mais representativa foi do Estado capitalista, o qual pressupõe avaliações controladoras, não caiu no gosto de seu maior incentivador - o mercado.

Exatamente devido a seu caráter controlador, o "Provão" foi criticado (i) pelo setor privado de educação; (ii) pela comunidade acadêmica; e (iii) pela União Nacional dos Estudantes (UNE). Como exemplifica Cunha (1997, p. 39), em novembro de 1996, por exemplo, "55 mil estudantes de 616 instituições foram chamados ao provão, mas, pelos cálculos do MEC, 6,4\% faltaram e 4\% entregaram a prova em branco, apoiando, assim, o boicote defendido pela UNE.". Certamente, contudo, os motivos que levaram esses grupos a rechaçarem o exame foram bem distintos. As instituições privadas podiam estar querendo apenas (i) expansão, (ii) cumprimento do mínimo que o Estado exigisse para sua manutenção, (iii) e poucos holofotes para resultados negativos. Enquanto os estudantes e a comunidade acadêmica, em geral, podiam querer uma avaliação que não fosse controladora, mas formativa e emancipadora. Para alguns, aparentemente,

[...] o discurso oficial de que os resultados desses exames orientariam as ações do governo, estimulando e fomentando iniciativas voltadas para a melhoria da qualidade do ensino, não se sustentou. Em essência, reproduzia uma tendência mundial de inverter questões sociais, econômicas e educacionais em problemas técnicos. (QUEIROZ, 2014, p. 137).

Contudo, mesmo envolta em tamanha insatisfação dos estudantes e do setor privado, a ênfase nas classificações, as quais eram altamente alardeadas pela mídia, (VERHINE; DANTAS, 2005), fez com que o ENC, contraditoriamente, conquistasse a população brasileira e pouco a pouco se tornasse hegemônico no contexto nacional. Seu instrumento de destaque - a prova - foi sendo gradativamente associado como único aferidor da qualidade dos cursos de graduação. Todavia,

[...] as provas aplicadas nesses oito anos (1996-2003) não indicavam um padrão e um escore mínimos para cada curso. Portanto, não é possível 
aceitar a tese da relação direta entre o desempenho agregado dos estudantes e a qualidade do curso. Somente seria possível comparar o desempenho demonstrado pelos estudantes de determinada sala de aula com os demais de outras instituições dentro da mesma área de conhecimento e no mesmo ano. Porém, não se criaram condições objetivas de comparação de um curso com outro. Como exame de larga escala, diferentemente do que se divulgava, o Provão não fazia avaliação da aprendizagem, mas media desempenhos. Os resultados dos desempenhos dos estudantes sofriam grandes alterações de um curso a outro e de um ano a outro, variando de acordo com a intensidade de aceitação ou recusa dos estudantes, a quantidade de boicotes, os graus de dificuldade de cada prova etc. (DIAS SOBRINHO, 2010, p. 205).

O Exame Nacional de Cursos, numa proposta inversa à do Paiub, encerrou, pois, pouco rigor técnico, muitas opiniões contrárias e um retorno aos processos avaliativos de caráter controlador, deixando de lado a dimensão institucional das IES. A marca deixada pelo ENC, por levar para a grande mídia os resultados do "Provão", foi a de ranqueamento das instituições, não tratando de forma mais consistente e ampliada os demais resultados da avaliação institucional. (MENEZES, 2012). Apesar de a política avaliativa empreendida por FHC prever um conjunto de avaliações, o que se sobressaiu na implementação foi o ENC, com todas as contradições e opiniões divergentes inerentes. Consequentemente, houve um enfraquecimento do

[...] entendimento da avaliação como política pública e a vinculou aos princípios de controle, simples comparação, rankings e perspectivas mercadológicas isoladas, contrárias aos princípios da autonomia. Pode-se dizer, então, que à exceção do Paiub e da CNRES, os demais grupos formados para alavancar a discussão sobre um processo de avaliação ficaram distantes do entendimento desta como política pública e, mais ainda, da sua ação indutora de qualidade. (GRIBOSKI, 2014, p. 122-123).

Assim, depois de ter-se explorado o percurso das políticas de avaliação da educação superior brasileira até a década 1990, faz-se interessante observar o quadro a seguir, de Barreyro (2008), para fins de uma síntese do que foi discutido até o momento. Nele, não está incluída a proposta do Exame Nacional de Cursos, no entanto, ainda oferece uma visão mais global do que foram as propostas explanadas neste tópico, conforme se pode observar a seguir: 
Quadro 4: Esquema das propostas de avaliação da educação superior brasileira nas décadas de 1980 e 1990

\begin{tabular}{|c|c|c|c|c|}
\hline $\begin{array}{c}\text { Documento/ } \\
\text { Tópico }\end{array}$ & $\begin{array}{c}\text { PARU } \\
1983\end{array}$ & $\begin{array}{c}\text { CNRE } \\
1985\end{array}$ & $\begin{array}{c}\text { GERES } \\
1986\end{array}$ & $\begin{array}{c}\text { Paiub } \\
1993\end{array}$ \\
\hline Autores & $\begin{array}{l}\text { Grupo gestor } \\
\text { (especialistas em } \\
\text { análise de } \\
\text { projetos, sendo } \\
\text { alguns técnicos } \\
\text { do MEC) }\end{array}$ & $\begin{array}{l}24 \text { membros } \\
\text { (heterogêneo) } \\
\text { provenientes da } \\
\text { comunidade } \\
\text { acadêmica e da } \\
\text { sociedade }\end{array}$ & $\begin{array}{l}\text { Grupo interno do } \\
\text { MEC }\end{array}$ & $\begin{array}{c}\text { Comissão } \\
\text { Nacional de } \\
\text { Avaliação } \\
\text { (representativa de } \\
\text { entidades) }\end{array}$ \\
\hline Objetivo & $\begin{array}{l}\text { Diagnóstico da } \\
\text { educação superior }\end{array}$ & $\begin{array}{c}\text { Propor nova } \\
\text { política de } \\
\text { educação superior }\end{array}$ & $\begin{array}{l}\text { Propor nova lei } \\
\text { de educação } \\
\text { superior }\end{array}$ & $\begin{array}{l}\text { Propor uma } \\
\text { sistemática de } \\
\text { avaliação } \\
\text { institucional }\end{array}$ \\
\hline $\begin{array}{c}\text { Função/ } \\
\text { Concepção de } \\
\text { avaliação }\end{array}$ & Formativa & Regulação & Regulação & Formativa \\
\hline Justificativa & $\begin{array}{l}\text { Investigação } \\
\text { sistemática da } \\
\text { realidade }\end{array}$ & $\begin{array}{l}\text { Contraponto da } \\
\text { autonomia. } \\
\text { Vincula } \\
\text { financiamento }\end{array}$ & $\begin{array}{l}\text { Contraponto da } \\
\text { autonomia. } \\
\text { Vincula } \\
\text { financiamento }\end{array}$ & $\begin{array}{c}\text { Prestação de } \\
\text { contas por ser um } \\
\text { bem público que } \\
\text { atinge a } \\
\text { sociedade }\end{array}$ \\
\hline Tipo de avaliação & Interna & Externa & Externa & $\begin{array}{l}\text { Auto-avaliação e } \\
\text { avaliação externa }\end{array}$ \\
\hline $\begin{array}{l}\text { Agentes da } \\
\text { avaliação }\end{array}$ & $\begin{array}{l}\text { Comunidade } \\
\text { acadêmica }\end{array}$ & $\begin{array}{c}\text { - Conselho } \\
\text { Federal de } \\
\text { Educação (para } \\
\text { as universidades) } \\
\text { - Universidades } \\
\text { (para as } \\
\text { faculdades } \\
\text { próprias) }\end{array}$ & $\begin{array}{l}\text { - Secretaria de } \\
\text { Educação } \\
\text { Superior (para a } \\
\text { Ed. Pública), } \\
\text { - Mercado (para a } \\
\text { Ed. Privada) }\end{array}$ & $\begin{array}{c}\text { Endógena e } \\
\text { voluntária }\end{array}$ \\
\hline $\begin{array}{l}\text { Unidade de } \\
\text { análise }\end{array}$ & Instituição & Instituição & Instituição & $\begin{array}{l}\text { Instituição, } \\
\text { iniciando pelo } \\
\text { ensino de } \\
\text { graduação }\end{array}$ \\
\hline Instrumentos & $\begin{array}{l}\text { Indicadores e } \\
\text { estudos de caso }\end{array}$ & $\begin{array}{l}\text { Indicadores de } \\
\text { desempenho }\end{array}$ & $\begin{array}{l}\text { Indicadores de } \\
\text { desempenho }\end{array}$ & $\begin{array}{c}\text { Indicadores de } \\
\text { desempenho }\end{array}$ \\
\hline
\end{tabular}

Fonte: Barreyro (2008, p. 148).

Modelos avaliativos como o Paru e o Geres, criados na década de 1980, e o Paiub e o ENC, criados na década de 1990, se constituíram como as primeiras propostas de avaliações sistemáticas da história da educação superior brasileira. Com o esquema sintético do quadro e as considerações realizadas neste item do capítulo, bem como no capítulo anterior, percebe-se que a lógica intrínseca às políticas avaliativas brasileiras conformam duas concepções de avaliação. Ainda que não se declare nas leis que as constituíram, a prática da implementação dessas políticas as divide em controladoras ou formativas. Enquanto em determinado período 
tinha-se no Brasil uma avaliação formativa, no subsequente já entrava em vigor uma controladora, sendo que essa última, tomando como base o ENC, prevalecia temporalmente. A evolução das políticas de avaliação da educação superior brasileira, portanto, foi repleta de embates e rupturas, como simbolicamente se vê na ilustração a seguir. Nela, encontra-se sintetizado o revezamento dos perfis avaliativos ilustrados neste tópico, tendo em conta que esse embate pode não ter acabado no ENC.

Ilustração 3: Enfoques da evolução das políticas de avaliação da educação superior brasileira e as diferentes concepções avaliativas

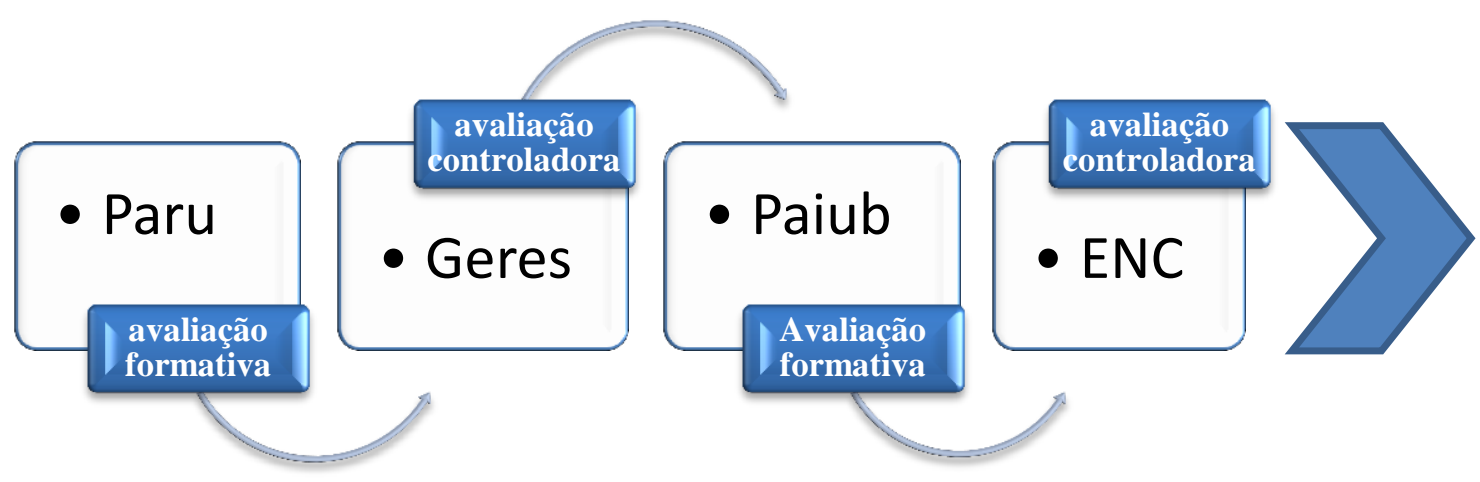

Fonte: Elaboração própria.

Uma das concepções de avaliação da educação superior, como visualizado, é aquela de caráter controlador, em que, representada pelo Geres e pelo ENC, prevalece a regulação; e a outra é aquela de caráter formativo e emancipatório, representada pelo Paru e Paiub, com destaque para esse último, no qual, além da regulação, a avaliação formativa ganha espaço, auxiliando, inclusive, no processo regulatório. Nessa última concepção, "avaliar consiste em pesquisar a instituição para detectar pontos a serem melhorados ou mantidos. A ideia subjacente é formativa, a avaliação é um subsídio para a melhoria da qualidade, por meio da avaliação institucional (Paru) e da avaliação interna (Paiub)”. (BARREYRO, 2008, p. 149).

$\mathrm{Na}$ sequência da história das políticas públicas de avaliação da educação superior brasileira, por sua vez, o sistema avaliativo que é instituído em 2004 - o Sinaes - trouxe em sua constituição o resgate aos princípios que já vinham se acumulando durante essas duas décadas de avaliação. Contudo, ele vem com a proposta de acabar com o embate existente entre avaliação formativa e avaliação controladora, como será discutido no tópico seguinte. 


\subsection{CONCEPÇÃO E IMPLEMENTAÇÃO DO SISTEMA NACIONAL DE AVALIAÇÃO DA EDUCAÇÃO SUPERIOR - OS EMPASSES E CONTRADIÇÕES DO PROCESSO}

Nas décadas de 1980 e 1990 viveu-se sob a égide de uma configuração de Estado que, seguindo uma tendência mundial, se inclinava a um modelo controlador de política educacional. É certo que, em termos de políticas avaliativas, o Saeb logrou ser mais do que um projeto, possibilitando às universidades uma avaliação formativa. Contudo, isso só foi possível enquanto ação independente do MEC e sem apoio governamental.

No governo FHC, o Saeb foi imediatamente subsumido pela política que se encaixava melhor ao capitalismo - o ENC, popularmente conhecido como "Provão". Esse, por sua vez, mesmo sofrendo muitas críticas, inclusive provenientes do mercado, sobreviveu aos dois mandatos do presidente em questão (1995 - 2002) e caiu no gosto da população.

Durante todo o período de implementação do ENC, e mesmo antes, já havia, contudo, um movimento por parte, especialmente, das universidades de se defender que a regulação, por si só, era apenas controle, o que nem fomentaria uma qualidade sob uma perspectiva ampla, nem auxiliaria o mercado em longo prazo. Esses posicionamentos defendidos, por sua vez, convergiam na ideia de que, diante desse contexto, seria preciso (i) uma resposta alternativa ao modelo de avaliação defendido até o momento; e (ii) que essa resposta viesse materializada em uma política avaliativa de Estado e não de governo.

Estudantes, professores e IES, por exemplo, já vinham demonstrando a incoerência de se ter constantes alterações de políticas avaliativas a cada sucessão governamental. E a meta $\mathrm{n}^{\text {o }} 7$ do PNE (2001-2011) (BRASIL, 2001) apareceu como uma das primeiras respostas a esses apelos. Essa apontou, entre outras questões, a necessidade de um compromisso estatal com a promoção de um sistema de avaliação das instituições e cursos de graduação. Só era necessário, então, um governo que abrisse o caminho para algo novo e diferente.

Com o fim dos mandatos de FHC, sobe ao cargo de Presidente da República Luís Inácio Lula da Silva, quem teria muitos desafios em termos de avaliação da educação superior. Como mostrado no capítulo 1 e no tópico anterior, o Estado, na figura dos governantes, vem historicamente implementando leis, planos e políticas avaliativas que colocam nas instituições expectativas relacionadas ao mercado. Uma avaliação voltada ao controle, como o ENC, era bastante capaz de promover nas IES mudanças em busca de eficiência (competitividade); mas em termos de expansão consciente ou formação de competências para além das exigências do mercado não. Como, porém, romper com isso? $\mathrm{O}$ 
Sinaes, inaugurado no governo Lula como política de Estado, estando, portanto, vigente até o momento, seria capaz? E a autoavaliação; que funcionalidade prática ocupa nesse contexto?

De acordo com pessoa entrevistada representante dos pesquisadores da área, "uma coisa é a formulação da lei e outra coisa é a prática"; e a autoavaliação, foco deste trabalho, teria, segundo essa, se transformado "muito com as mudanças que o Sinaes teve" (P2, informação verbal). Na continuação, então, se situa o contexto legal e político específico do objeto de pesquisa - a autoavaliação, bem como sua implementação no país, em termos gerais. Nesse processo se levará em consideração três questões: (i) que a prática da autoavaliação é relativamente nova, estando pela primeira vez colocada como ação obrigatória; (ii) que equalizar regulação e avaliação formativa não é tão simples, especialmente quando o histórico de avaliações anteriores converge para o contrário; e (ii) que apesar da proposta do Sinaes ser formativa, sua prática no processo de implementação pode ter caminhado para outro rumo.

Fazer esse panorama geral do Sinaes oferece suporte teórico-conceitual ao estudo empírico e é importante para uma pesquisa com foco na autoavaliação institucional, como esta. Caso o Sinaes, assim como Rodrigues (2015) e Polidori (2009) defendem, venha se distanciado consideravelmente de sua proposta original a ponto de desequilibrar as devidas importâncias de cada um de seus três pilares, a autoavaliação pode estar sendo subsumida. E uma vez nessa condição coadjuvante, pode haver interferência no modo como os sujeitos da pesquisa percebem o processo autoavaliativo na UnB e lidam com ele.

\subsubsection{CONCEPÇÃO DO SINAES}

Neste item se analisará o momento de formulação do Sinaes - com as principais intenções originais desse -, o qual, por si só, já conforma todos os impasses inerentes a uma mudança na perspectiva da avaliação da educação superior do país. Essa nova política tem seu embrião no início do primeiro mandato de Luiz Inácio Lula da Silva na Presidência da República (2003-2006) e tendo, a princípio, Cristovam Buarque como Ministro da Educação.

À época, acatando-se a sugestão do MEC, formou-se em 2003, por meio das Portarias MEC/SESu n ${ }^{\circ} 11$, de 28 de abril e de 27 de maio do mesmo ano, a Comissão Especial de 
Avaliação $(\mathrm{CEA})^{55}$ da Educação Superior, com o encargo de dar os primeiros passos à inovação da avaliação da educação superior. Essa, era composta por representantes da SESu, do Inep, do MEC, da UNE e de especialistas de IES públicas e privadas e teve suas reflexões e estudos corroborados por 38 entidades representativas de distintos setores da sociedade, em especial relacionados à educação superior. Observando somente a formação dessa Comissão já se percebe que o governo estava aparentemente disposto a ouvir os anseios das pessoas envolvidas com a educação, não fazendo nada de forma arbitrária.

A finalidade dessa Comissão, por sua vez, era "analisar, oferecer subsídios, fazer recomendações, propor critérios e estratégias para a reformulação dos processos e políticas de avaliação do ensino superior e elaborar a revisão crítica dos seus instrumentos, metodologias e critérios utilizados." (BRASIL/MEC/SESu, 2003, art. $1^{\text {º }}$. Em resumo, ela era responsável, portanto, por subsidiar a criação de uma nova política de avaliação da educação superior brasileira; e assim o fez por meio da apropriação "de análises e diagnósticos dos aspectos normativos da avaliação e regulação existentes, bem como de audiências públicas e depoimentos de estudiosos da área." (QUEIROZ, 2014, p. 150).

Duas das questões mais controversas que a CEA teve que discutir foi (i) a criação ou não de uma avaliação dos estudantes, a qual viria depois a tornar-se o Enade; e (ii) a finalidade principal da avaliação, se formativa ou exclusivamente regulatória. Sobre isso, Stela Maria Meneghel, que além de ter sido um dos membros da CEA, era, à época de publicação desta dissertação, responsável pela Coordenação Geral de Controle de Qualidade da Educação Superior (CGCQES), tece alguns comentários relevantes em entrevista ${ }^{56}$. Segundo a Coordenadora, o tema do Enade

\footnotetext{
${ }^{55}$ Presidida pelo professor José Dias Sobrinho (UNICAMP), esta Comissão Especial de Avaliação foi integrada pelos seguintes membros: "professores Dilvo Ilvo Ristoff (UFSC), Edson Nunes (UCAM), Hélgio Trindade (UFRGS), Isaac Roitman (CAPES), Isaura Belloni (UnB), José Ederaldo Queiroz Telles (UFPR), José Geraldo de Sousa Junior (SESu), José Marcelino de Rezende Pinto (INEP), Júlio César Godoy Bertolin (UPF), Maria Amélia Sabbag Zainko (UFPR), Maria Beatriz Moreira Luce (UFRGS), Maria Isabel da Cunha (UNISINOS), Maria José Jackson Costa UFPA), Mario Portugal Pederneiras (SESu), Nelson Cardoso Amaral (UFG), Raimundo Luiz Silva Araújo (INEP), Ricardo Martins (UnB), Silke Weber (UFPe), Stela Maria Meneghel (FURB) e pelos estudantes Giliate Coelho Neto, Fabiana de Souza Costa e Rodrigo da Silva Pereira, representando a União Nacional de Estudantes (UNE). Daniel Ximenes foi o coordenador executivo, assessorado por Adalberto Carvalho, ambos da Sesu e contou ainda com a colaboração especial de Teofilo Bacha Filho do Conselho Estadual de Educação do Paraná." (BRASIL/MEC/SESu, 2003, p. 7).

${ }^{56}$ A entrevista com Stela Maria Meneghel foi realizada por Robl, Fabiane; Mello, Paulo Eduardo Dias de; Ricci, Claudia Sapag; e Marinho-Araújo, Claisy em janeiro de 2015 e publicada pelos mesmos no ano em questão. Nela, Meneghel discute o processo de implementação do Sinaes, problematizando a formulação das políticas de avaliação no país e a criação da CEA e da Conaes. Por nesta dissertação se ter recorrido apenas à fala da entrevistada e não às dos entrevistadores, optou-se por durante todo o texto as citações serem seguidas do sobrenome da primeira (Meneghel). Nas referências bibliográficas, especificamente, consta primeiramente o nome da entrevistada e imediatamente em seguida os dos entrevistadores.
} 
[...] ou do que ele veio a ser, não era consensual. Ao contrário: para algumas pessoas era óbvio que não deveria haver Enade, porque na concepção de avaliação formativa e tudo mais o foco não estaria no desempenho individual do estudante, tal como fazia o Provão, em que o resultado ia direto para o histórico escolar. E, para outras, parecia um absurdo perder a experiência de 7 anos de ENC. "Nós vamos perder essa informação? Ela é importante" alguns diziam. [...] Também a discussão sobre o uso dos resultados, avaliação e regulação, foi presente todo o tempo e bastante difícil. Porque era forte em grande parte do grupo que não se deveria fazer uma avaliação apenas com objetivo de regulação; não era isso que se propunha. Por outro lado, era claro que a avaliação deveria dar elementos, subsídios - tal como está na lei - para que pudessem ser tomadas as medidas necessárias para acompanhamento e supervisão de IES. (MENEGHEL, 2015, p. 189-190).

Depreende-se dessa colocação da entrevistada que, a começar pela CEA, o embate sobre que tipo de avaliação se criar já era um grande empasse. Após várias discussões em torno disso e de outros temas, no entanto, se chegou a algumas diretrizes comuns; e uma proposta foi publicada em agosto de 2003 no documento intitulado SINAES: bases para uma nova proposta de avaliação da educação superior brasileira (BRASIL/MEC/SESu, 2003), o qual foi divulgado amplamente em audiências públicas do país destinadas a sua discussão. Nesse documento, a CEA defende que o papel do Estado na conjuntura da época em questão já não podia limitar-se à regulação no sentido do controle burocrático e ordenamento. Ao Estado competia-lhe, sobretudo,"avaliar a educação superior de modo a fornecer elementos para a reflexão e propiciar melhores condições de desenvolvimento". (BRASIL/CEA, 2003, p. $85)$.

Além disso, a CEA considerava em seu documento a autoavaliação institucional como componente central do sistema avaliativo e os seguintes itens como critérios básicos para a implementação do que viria a ser o Sinaes: (i) educação como direito social e dever do Estado; (ii) respeito aos valores sociais historicamente determinados; (iii) superação da concepção e prática da regulação como mera função burocrática e legalista; (iv) prática social com objetivos educativos; (v) respeito à identidade e à diversidade institucionais em um sistema diversificado; (vi) globalidade; (vii) legitimidade; e (viii) continuidade.

No entanto, o então Ministro da Educação, Cristovam Buarque, desconsiderou o trabalho realizado pela CEA, encaminhando à Casa Civil, no lugar da proposta empreendida por essa, a sugestão de instituição de uma espécie de índice para medir a qualidade da educação superior do país. Ao novo documento apresentado se deu o nome de Sistema Nacional e Progresso do Ensino Superior (Sinapes), o qual se apoiava, por sua vez, em quatro pilares. Eram esses: (i) o processo de ensino a partir da formação do corpo docente; (ii) o processo de aprendizagem baseado em exame nacional; (iii) a capacidade institucional de 
informação sobre a instituição; e (iv) a responsabilidade do curso com a sociedade. Uma vez aprovada a instituição desse índice, "o MEC continuaria classificando os cursos e respondendo aos anseios e às necessidades da sociedade e também do governo.”. (DUARTE, 2013, p. 124). Uma vez aprovada, portanto, se teria retorno a avaliações como a do Geres e do ENC, e não inovação. A proposta do Sinapes estava presente na Medida Provisória $n^{\circ} 147$ de 15 de dezembro de 2003 (BRASIL, 2003c), que criava o sistema de avaliação. Todavia, quando houve no Congresso Nacional a votação do Projeto de Lei de Conversão da Medida Provisória, o sistema foi, felizmente, recusado. Nessa conversão decidiu-se que eram as propostas da CEA as mais pertinentes. Segundo Meneghel (2015), logo

[...] em seguida o ministro foi demitido e seu sucessor, Tarso Genro, resolveu dar atenção àquela proposta que parecia ter sido descartada. [...] O ministro Tarso Genro teve papel fundamental na aprovação da Lei do Sinaes, pois acolheu o trabalho da Comissão e, com membros do seu gabinete, participou das negociações para sua aprovação no Congresso. (p.193).

Ainda que a proposta da CEA não tenha sido considerada na íntegra na instituição e implementação do Sinaes, a mudança de ministro e a retomada parcial dessa "representou um avanço ímpar, inaugural na arquitetura de um trabalho sistêmico da avaliação da educação superior brasileira, configurando a avaliação institucional como centro.”. (QUEIROZ, 2014, p. 151).

Nesse contexto, o Sinaes foi instituído por meio da Lei $\mathrm{n}^{\circ} 10.861$, de 14 de abril de 2004 (BRASIL, 2004a). Sua operacionalização ficou a cargo do Inep, o qual contaria com a parceria da SESu, da Secretaria de Educação Profissional e Tecnológica (Setec) e da Secretaria de Educação a Distância (Seed). E sua coordenação e supervisão seria realizada pela Conaes, a qual havia sido criada para esse fim. ${ }^{57}$

O objetivo do Sinaes era "assegurar processo nacional de avaliação das instituições de educação superior, dos cursos de graduação e do desempenho acadêmico de seus estudantes para fins de promover a melhoria da qualidade da educação superior.”. (BRASIL, 2004a, art. $1^{\circ}$ ). No entanto, contar com a função coordenativa e supervisora da Conaes e executiva do Inep, desde o início não foi algo tão simples. Nem o Inep, nem a Conaes apresentava infraestrutura suficiente para atender às demandas que lhes cabia. De acordo com Meneghel (2015),

\footnotetext{
${ }^{57}$ Enquanto a Conaes foi criada para dar suporte ao Sinaes, o Inep não tem o Sistema como seu único encargo. O Inep é, desde a Lei $\mathrm{n}^{\circ}$ 9.448, de 14 de março de 1997, uma autarquia federal vinculada ao Ministério da Educação (BRASIL, 1997), e sua missão é promover estudos, pesquisas e avaliações sobre o sistema educacional brasileiro no que tange à educação infantil, básica e superior.
} 
[...] o Sinaes foi pensado e começou a existir - lei publicada - sem que houvesse nada organizado nesse sentido [infraestrutura]. Isso gerou problemas enormes porque, de um lado, a Conaes funcionava em condições absolutamente precárias, apesar da "boa vontade" e apoio de diversos órgãos - CNE, SESu, Capes. O Inep, por sua vez, também não tinha condições de abarcar e fazer, sozinho e com rapidez, todas as ações que lhe foram atribuídas para fazer o Sinaes acontecer. (p.194).

Assim, ainda que sob objeções iniciais e falta de planejamento de suporte, o Sinaes foi implementado. No começo, essa nova política veio com uma proposta de inovação e rompimento às velhas práticas rechaçadas pela academia, defendendo ser necessário que a regulação não se esgotasse em si mesma, mas, do contrário, se articulasse à avaliação educativa propriamente dita, tornando-se também uma prática formativa e construtiva. (BRASIL/Inep, 2009). Disso e de seu objetivo geral se depreende a intenção de distanciar-se da lógica exclusivamente reguladora, presente nas políticas do Geres e ENC, e, logo, nos ideais governamentais de todos os governos anteriores. Em consonância a isso, segundo o texto da Lei, o Sinais tinha como finalidades:

[...] a melhoria da qualidade da educação superior, a orientação da expansão da sua oferta, o aumento permanente da sua eficácia institucional e efetividade acadêmica e social e, especialmente, a promoção do aprofundamento dos compromissos e responsabilidades sociais das instituições de educação superior, por meio da valorização de sua missão pública, da promoção dos valores democráticos, do respeito à diferença e à diversidade, da afirmação da autonomia e da identidade institucional. (BRASIL, 2004a, Art. $1^{\circ}, \S 1^{\underline{0}}$ ).

Parecia compreender-se, então, que a avaliação se esgota quando se limita aos efeitos regulatórios pelo Poder Público. Logo, complementarmente, a partir do documento “Diretrizes para a avaliação das instituições de educação superior", publicado no mesmo ano, estabelece-se que os momentos de avaliação e regulação seriam separados e complementares. São, esses, 3 momentos:

(1) O da regulação, enquanto atributo próprio do Poder Público, que precede ao processo de avaliação nas etapas iniciais de autorização e do credenciamento dos cursos; (2) $\mathrm{O}$ do processo de avaliação que se realiza automaticamente pela instituição, de forma integrada e segundo suas diferentes modalidades; e (3) o da regulação novamente, uma vez concluída a avaliação (após emissão de pareceres da Conaes), quando são aplicados os efeitos regulatórios - previstos em lei - decorrentes da avaliação. (BRASIL/Inep/Conaes, 2004a, p. 7). 
O Sinaes, portanto, serviria à regulação, mas sem perder de vista a necessidade da avaliação formativa, o que, nas palavras de Meneghel (2015), na entrevista outrora referenciada, significa dizer que "a avaliação devia ter consequências, o que não significava perda do caráter pedagógico e formativo, tampouco promoção de medidas de regulação imediatas a partir de um resultado X, mas a convivência de ambas, de alguma maneira.". (p. 190).

A contemplação de ambos os aspectos - formativo e regulatório -, por sua vez, se daria por meio de um sistema avaliativo que se pretendia capaz de "assegurar, entre outras coisas, a integração das dimensões internas e externas, particular e global, somativo e formativo, quantitativo e qualitativo e os diversos objetos e objetivos da avaliação" (BRASIL/Inep 2009, p. 91-92). Mas será que fazê-lo era algo fácil? Uma vez logrando isso, o Sistema estaria contemplando, de acordo com Cardoso e Dias Sobrinho (2014), duas ideias centrais representantes do que seria a inovação da política avaliativa da educação superior: a de integração e a de participação.

A ideia de integração relaciona-se com a utilização de múltiplos instrumentos e dimensões e a combinação de diversas metodologias para a formação de um conceito global. A ideia da participação ocorreria por meio do envolvimento de toda a comunidade acadêmica com o processo avaliativo, de modo a assegurar o comprometimento com as mudanças e a criar uma cultura de avaliação nas IES. (p. 267).

Tudo isso, por sua vez, se daria na interlocução de três pilares ou eixos, os quais já foram citados nas considerações iniciais desta pesquisa: (i) a Avaliação dos Cursos de Graduação (ACG), (ii) a Avaliação do Desempenho dos Estudantes (a princípio pela Avaliação Integrada do Desenvolvimento Educacional e da Inovação da Área - Paideia e posteriormente pelo Exame Nacional de Avaliação de Desempenho dos Estudantes - Enade), e (iii) a Avaliação das Instituições da Educação Superior (Avalies) (autoavaliação e avaliação externa). Esses pilares captariam indicadores de qualidade em diferentes níveis e enfoques, os quais, por sua vez, deveriam ser analisados de modo integrado e levando em consideração que o Avalies seria o elemento central, organizador da coerência do conjunto. (BRASIL/Inep, 2009). Não suficiente, as avaliações ocorreriam em um mesmo período, mas em momentos diferentes, formando-se, ao fim, um ciclo completo de avaliação ${ }^{58}$.

\footnotetext{
${ }^{58}$ O ciclo avaliativo, conforme o artigo 33 da Portaria $\mathrm{n}^{\circ}$ 40/2007, republicada em 29 de dezembro de 2010, "compreende a realização periódica de avaliação de instituições e cursos superiores, com referência nas avaliações trienais de desempenho de estudantes, as quais subsidiam, respectivamente, os atos de recredenciamento e de renovação de reconhecimento" (BRASIL/MEC, 2010, art. 33).
} 
A Avaliação dos Cursos de Graduação subsidiaria os atos autorizativos de cursos autorização, reconhecimento e renovação de reconhecimento -, para a licenciatura, bacharelado e tecnólogo da modalidade presencial e também à distância. Para tanto, se utilizará "procedimentos e instrumentos diversificados, dentre os quais obrigatoriamente as visitas por comissões de especialistas das respectivas áreas do conhecimento". (BRASIL, 2004, art. 4).

Os avaliadores de cursos avaliariam determinado curso em três dimensões, levando em consideração uma escala de 1 a 5, também utilizada para a avaliação institucional externa. Cada dimensão, por sua vez, possui pesos diferentes na avaliação em virtude do processo para o qual está sendo utilizada - se para autorização, reconhecimento ou renovação de reconhecimento. Na tabela 3, a seguir, encontram-se as dimensões com seus respectivos pesos a depender da situação:

Tabela 3: Pesos estabelecidos em 2015 para as dimensões que corroboram os processos de autorização, reconhecimento e renovação de reconhecimento no Sinaes

\begin{tabular}{|c|c|c|}
\hline Dimensões & $\begin{array}{l}\text { Pesos para autorização } \\
\text { de cursos }\end{array}$ & $\begin{array}{l}\text { Pesos para reconhecimento e renovação de } \\
\text { reconhecimento de cursos }\end{array}$ \\
\hline $\begin{array}{l}\text { Organização didático- } \\
\text { pedagógica }\end{array}$ & 30 & 40 \\
\hline Corpo docente e tutorial & 30 & 30 \\
\hline Infraestrutura & 40 & 30 \\
\hline
\end{tabular}

Fonte: BRASIL/Inep/Daes (2015).

Observa-se na Tabela 3 que no que se refere a cursos, a qualidade seria atestada e induzida com base em (i) uma infraestrutura compatível às exigências do curso; (ii) professores e tutores qualificados; e (iii) a uma boa organização didático-pedagógica. A infraestrutura, especificamente, tem peso maior que as outras dimensões quando para a autorização do curso; mas para o reconhecimento ou renovação de reconhecimento de curso a organização didático pedagógica é mais determinante.

O resultado da avaliação, por sua vez, resultaria na atribuição de um Conceito de Curso (CC) em uma escala de 1 a 5, calculado "com base na média aritmética ponderada dos conceitos das dimensões, os quais são resultados da média aritmética simples dos indicadores das respectivas dimensões.”. (BRASIL/Inep/Daes, 2015, p. 2).

Para, então, que um curso de determinada IES recebesse autorização, reconhecimento ou renovação de reconhecimento teria que passar por esse processo, o qual apresentava como figura determinante e indispensável o avaliador de curso, previamente selecionado e treinado. 
No tópico seguinte, que traz a implementação da política do Sinaes, se verá, no entanto, que a principal prerrogativa desse pilar - a avaliação in loco realizada por avaliadores - será, em muitos casos, dispensada, com o passar do tempo.

A Avaliação do Desempenho dos Estudantes, também utilizaria uma escala de 1 a 5 , como o ACG e também forneceria embasamento para melhoria da qualidade dos cursos; contudo, nesse caso, isso seria feito dando voz ao discente. Quando da formulação da política, o processo avaliativo representante desse pilar seria a Avaliação Integrada do Desenvolvimento Educacional e da Inovação da Área - Paideia, a qual, segundo Dias Sobrinho (2010, p. 212), não

[...] se tratava simplesmente de constatar desempenhos de estudantes, mas de avaliar as grandes tendências curriculares, as dinâmicas formativas e as relações interdisciplinares de conjuntos de cursos que constituem as grandes áreas do conhecimento, como ciências humanas, exatas, tecnológicas e da saúde.

A Paideia entendia, portanto, que avaliar o desempenho de estudantes não se reduzia a checar o que o mesmo sabe ou não sobre determinado assunto. Na implementação da política, sobre o que se versará a seguir, tem-se que a essência não reducionista da Paideia segue na implementação do Sinaes, contudo, o foco no resultado dos estudantes e em índices passíveis de serem feitos a partir desses torna-se gradativamente o mais importante - fatores que não se encontravam na Paideia.

A avaliação institucional, por sua vez, além de utilizar-se, complementarmente, da avaliação de cursos e da de desempenho de estudantes, objetivaria identificar o perfil e o significado da atuação das IES, "pautando-se pelos princípios do respeito à identidade e à diversidade das instituições, bem como pela realização de autoavaliação e de avaliação externa." (BRASIL, 2004a, art. $9^{\circ}$ ). Para tal, tanto na avaliação externa como na autoavaliação institucional se consideraria até o ano de $2010 \mathrm{dez}$ dimensões a serem avaliadas, as quais foram apresentadas nas considerações iniciais deste trabalho de forma concisa. No quadro 5 a seguir é possível apreciar as dimensões de maneira mais explicativa e visualmente pedagógica. 
Quadro 5: Dimensões para a autoavaliação e avaliação externa

\begin{tabular}{|c|}
\hline Dimensões \\
\hline 1. A missão e o plano de desenvolvimento institucional. \\
\hline $\begin{array}{l}\text { 2. A política para o ensino, a pesquisa, a pós-graduação, a extensão e as respectivas normas de } \\
\text { operacionalização, incluídos os procedimentos para estímulo à produção acadêmica, para as bolsas } \\
\text { de pesquisa, de monitoria e demais modalidades. }\end{array}$ \\
\hline $\begin{array}{l}\text { 3. A responsabilidade social da instituiçãa, considerada especialmente no que se refere à sua } \\
\text { contribuição em relação à inclusão social, ao desenvolvimento econômico e social, à defesa do meio } \\
\text { ambiente, da memória cultural, da produção artística e do patrimônio cultural. }\end{array}$ \\
\hline 4. A comunicação com a sociedade. \\
\hline $\begin{array}{l}\text { 5. As políticas de pessoal, de carreiras do corpo docente e corpo técnico-administrativo, seu } \\
\text { aperfeiçoamento, seu desenvolvimento profissional e suas condições de trabalho. }\end{array}$ \\
\hline $\begin{array}{l}\text { 6. Organização e gestão da instituição, especialmente o funcionamento e representatividade dos } \\
\text { colegiados, sua independência e autonomia na relação com a mantenedora, e a participação dos } \\
\text { segmentos da comunidade universitária nos processos decisórios. }\end{array}$ \\
\hline $\begin{array}{l}\text { 7. Infraestrutura física, especialmente a de ensino e de pesquisa, biblioteca, recursos de informação } \\
\text { e comunicação. }\end{array}$ \\
\hline $\begin{array}{l}\text { 8. Planejamento e avaliação, especialmente em relação aos processos, resultados e eficácia da } \\
\text { autoavaliação institucional. }\end{array}$ \\
\hline 9. Políticas de atendimento aos estudantes. \\
\hline $\begin{array}{l}\text { 10. Sustentabilidade financeira, tendo em vista o significado social da continuidade dos } \\
\text { compromissos na oferta da educação superior. }\end{array}$ \\
\hline
\end{tabular}

Fonte: BRASIL, (2004a, art. 3).

No caso da avaliação externa, avaliadores pré-selecionados avaliariam a IES nas dimensões citadas levando em consideração (i) o relatório produzido pela Comissão Própria de Avaliação no outro processo - a autoavaliação -; (ii) o Plano de Desenvolvimento Institucional (PDI); (iii) as Diretrizes Curriculares Nacionais (DCN); (iv) os dados do Censo da Educação Superior e (v) a uma observação realizada in loco. (BRASIL/Inep/Conaes, 2004a). Como desdobramento dessa análise, os avaliadores elaborariam, em um segundo momento, um relatório institucional que contemple todo o perscrutado durante a visita e apreciação dos documentos.

Os resultados do processo de avaliação da instituição, envolvendo autoavaliação e avaliação externa, expressos nesse relatório, serão encaminhados à Conaes para a elaboração de seu parecer conclusivo. Esse parecer, encaminhado para órgãos competentes, será a base para subsidiar a melhoria da qualidade acadêmica e o desenvolvimento de políticas internas da IES, bem como para a implantação ou manutenção de políticas públicas relacionadas à regulação do sistema de educação superior do país. A Lei $n^{\circ}$ 10.861/2004 prevê, para os resultados considerados insatisfatórios, a celebração de um Protocolo de Compromisso entre o MEC e a respectiva instituição. (BRASIL/Inep/Conaes, 2004a, p. 15). 
Com isso, entre outras questões, as comissões externas ajudariam a identificar acertos e equívocos da autoavaliação. Nessa última, por sua vez, uma Comissão Própria de Avaliação de cada IES ficaria incumbida de, por meio de suas próprias metodologias e discussões, autoavaliar a instituição com base em cada uma das dimensões exigidas e mais naquelas que emergissem durante o processo avaliativo. Esse processo era, no entanto, algo novo para a maioria das IES. Antes da instituição do Sistema, a autoavaliação existia por adesão voluntária das universidades ao Paiub, quando à época desse, ou por espontaneidade de cada instituição de educação, como foi o caso da UnB. Com o advento do Sinaes, se autoavaliar se torna ação obrigatória e organizada e a Conaes ajudou a dar os direcionamentos iniciais para sua realização. Como diz Meneghel (2015), na

[...] interlocução com as IES a Conaes teve um importante protagonismo. Foram muitos seminários com a preocupação de mostrar o sistema, depois de mostrar o roteiro de autoavaliação, o que era uma CPA... orientávamos diretamente as IES. Essa ação foi significativa porque o Inep não podia fazer isso sozinho. (p.199-200).

Percebe-se na fala da Coordenadora o empenho da Conaes no período inicial do Sinaes para fazer com que as IES compreendessem o que era a autoavaliação. Como consta no artigo 11 da Lei 10.861/2004, que cria o Sinaes, cada IES, sendo pública ou privada teve que constituir uma CPA apenas "no prazo de 60 (sessenta) dias, a contar da publicação desta Lei, com as atribuições de condução dos processos de avaliação internos da instituição, de sistematização e de prestação das informações solicitadas pelo INEP”. (BRASIL, 2004a). Consequentemente, a Conaes teve papel inicial importante, auxiliando no processo. Os encargos da CPA recém-constituída, por sua vez, eram muitos. A ela caberia obedecer às seguintes diretrizes:

[...] I - constituição por ato do dirigente máximo da instituição de ensino superior, ou por previsão no seu próprio estatuto ou regimento, assegurada a participação de todos os segmentos da comunidade universitária e da sociedade civil organizada, e vedada a composição que privilegie a maioria absoluta de um dos segmentos; II - atuação autônoma em relação a conselhos e demais órgãos colegiados existentes na instituição de educação superior. (BRASIL, 2004a, art. 11).

A necessária participação de todos os segmentos que formam a comunidade acadêmica deveria dar-se, equilibradamente, por docentes, discentes, técnico-administrativos e representantes da sociedade civil organizada da região onde se localiza a instituição de 
educação superior. Uma vez formadas as CPA sob esse modelo, a autoavaliação empreendida por elas se daria em um processo de três diferentes momentos/fases, já citados, igualmente, nas considerações iniciais da pesquisa. São eles: (i) preparação, (ii) desenvolvimento e (iii) consolidação (BRASIL/Inep/Conaes, 2004a; 2004b), conforme a ilustração exemplificativa a seguir:

Ilustração 4: Três momentos/fases que compõem a autoavaliação no Sinaes

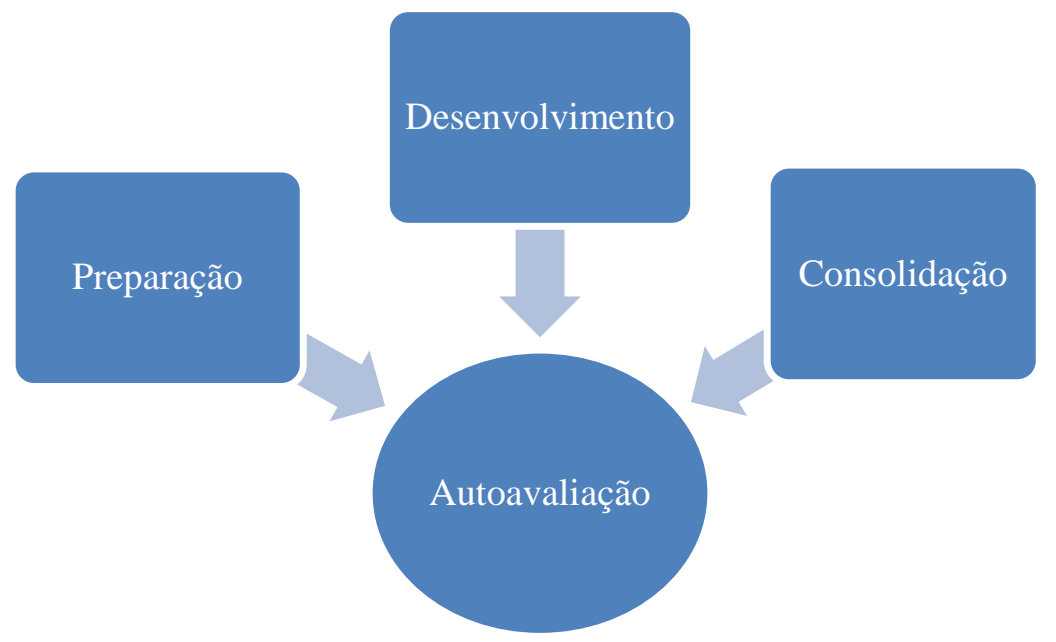

Fonte: Elaboração própria.

A primeira etapa, preparação, compreende a constituição da CPA; a sensibilização interna sobre a importância da autoavaliação; a presença de representantes da instituição em seminários regionais de avaliação promovidos pelo Inep e Conaes; a criação de estratégias de envolvimento da comunidade acadêmica no processo autoavaliativo; e a elaboração de um plano de autoavaliação.

A segunda etapa, desenvolvimento, é posta em prática por seis atividades. Em primeiro lugar seriam implementados os procedimentos de coleta e análise de informações. Em seguida, se elaboraria relatórios parciais relativos às diferentes etapas de autoavaliação e avaliação externa da IES. Depois se faria uma integração da autoavaliação aos demais instrumentos avaliativos do Sinaes. Após isso, um detalhamento da avaliação externa, em sintonia com as orientações da Conaes. Logo após, uma elaboração de relatórios parciais ou finais da avaliação interna e da externa. E, por fim, a revisão do projeto de avaliação do Sinaes da IES e o eventual replanejamento das atividades para a continuidade do processo de avaliação, sempre levando em conta a necessária sensibilização aos agentes da IES.

A terceira etapa, consolidação, por sua vez, se daria pelo fechamento dos relatórios de autoavaliação, divulgação desses para toda a comunidade acadêmica e um balanço crítico 
de todo o processo, com a finalidade de "possibilitar a elaboração de propostas de políticas institucionais e, ainda, de redefinição da atuação ou da missão institucional.”. (BRASIL/Inep/Conaes, 2004a, p. 19). Os relatórios, vale dizer, seriam enviados à Conaes seguindo um cronograma previamente acordado, e essa os encaminharia à Comissão externa de avaliação, anteriormente citada, que, por sua vez, daria continuidade à avaliação institucional externa.

Com base nesse processo, a instituições de educação superior buscaria "compreender os significados do conjunto de suas atividades para melhorar a qualidade educativa e alcançar maior relevância social.”. (BRASIL/Inep/Conaes, 2004b, p. 6). Seria, portanto, o momento que mais simbolizaria a implantação de uma mudança na política pública de avaliação da educação superior do país, pois, de controladas e subordinadas, as instituições passariam a autoras da avaliação.

A avaliação institucional, e a autoavaliação, em específico, deveria, nesse contexto, ser o elemento fundamental da avaliação e norteadora principal das tomadas de decisão pela gestão das IES. Além de seus resultados poderem servir para a melhoria da qualidade, dos objetivos e da própria missão institucional, ainda são capazes de dar "sustentação tanto à regulação, imposta pelo Estado, quanto à instituição que usará o resultado para a tomada de decisão.” (MENEZES, 2012, p. 78).

Endossando essa importância, Sousa e Gonçalves (2014), a partir de um levantamento bibliográfico sobre a caracterização da qualidade da educação superior em dissertações e teses sobre avaliação, selecionaram doze trabalhos que se debruçaram sobre uma tentativa de contextualização do conceito de qualidade. Entre esses, destacaram cinco sobressalentes, a partir dos quais constataram, entre outras considerações, que a autoavaliação fora apontada como o instrumento mais capaz de fomentar qualidade, especialmente por trazer as reflexões das próprias IES. Não suficiente, segundo o entrevistado da Conaes, seria a autoavaliação o processo mais enriquecedor do Sinaes, o que se confirma na fala a seguir:

Nós temos a autoavaliação, nós temos a avaliação institucional externa, avaliação de curso, nós temos avaliação de estudante, mas nada na minha percepção é mais enriquecedor, é mais pedagógico, mais construtivo do que o processo de autoavaliação. Porque o processo de autoavaliaçao é aquele processo de autoconhecimento. E a partir do momento que você tem o conhecimento, você tem um diagnóstico, aí sim você pode fazer um planejamento com muito mais base, com muito mais substância. (CO, informação verbal). 
Em suma, a avaliação institucional, composta pela autoavaliação e avaliação externa, teria grande destaque no Sinaes e nas instituições de educação superior, em específico. O que se verá no tópico seguinte sobre a implementação da política, no entanto, é que por mais que, como será visto, tenham sido feitos aprimoramentos nesse pilar, a importância prevista não se consolidou na prática.

Em suma, todos os pilares compuseram juntos uma proposta avaliativa que realmente serviria à finalidade formativa e à regulatória. A partir deles, tanto se poderia promover a reflexão interna das IES, gestão participativa, planejamento institucional, etc., como subsidiar atos de credenciamento, renovação de credenciamento, autorização e reconhecimento de cursos, por exemplo. Conforme Ribeiro (2012), com

[...] essa nova sistematização, ficam claras algumas configurações da ação do Estado na educação superior: a separação entre avaliação e regulação; a definição da avaliação institucional como foco; a instauração de um processo de avaliação formativo; a interface que deve ser estabelecida entre avaliação e regulação. (p. 307).

Uma proposta, contudo, nem sempre se coaduna como tal na prática. Especificamente sobre a definição da avaliação institucional como foco do Sinaes, Meneghel (2015) confirmou a importância atribuída a esse eixo avaliativo ao classifica-lo como "grande eixo". Segundo a Coordenadora Geral de Controle de Qualidade da Educação Superior, a avaliação institucional

[...] era, de fato, o grande eixo da proposta do Sinaes; uma preocupação que vinha forte e diretamente do Paiub. O foco era a construção de uma cultura de autoavaliação institucional, em que a instituição tem, a partir da avaliação interna, seu momento de reflexão, de repensar planos, diretrizes e metas, com consequências e desdobramentos para a ação dos gestores. Com o tempo esse processo deveria tornar-se uma atividade incorporada no cotidiano - cultura avaliativa. Este era o grande eixo: a avaliação institucional. (p. 191).

No processo de implementação do Sistema Nacional de Avaliação da Educação Superior, no entanto, os três pilares que formam o sistema avaliativo se conformam de maneiras um tanto diferentes e divergentes da proposta original. Claro que o fato de o projeto não ser equivalente à prática é algo natural em qualquer política pública. Para alguns autores, no entanto, isso se deve a desde sua formulação o Sistema ter sido inspirado em elementos de avaliações passadas, que tinham paradigmas divergentes entre si. Segundo Barreyro e Rothen (2006), a 
[...] cumulação dos mecanismos de avaliação foi realizada sem considerar que cada um deles é produto de valores e paradigmas divergentes: a visão formativa/emancipatória do PAIUB, fundada na participação e na autonomia institucional, a visão somativa da Avaliação das Condições de Ensino e o mecanismo de ranking do Provão. (p. 971).

Ao afirmarem isso, Barreyro e Rothen (2006) compõem uma relação de equivalência entre o passado e o presente, o que é, na visão da autora desta pesquisa, em certa medida, equivocada. Mesmo que, como se viu neste item, o Sinaes tenha sido influenciado por avaliações passadas, essa política faz parte de outro tempo, de outra configuração histórica e política. No Sistema Nacional de Avaliação da Educação Superior encerra-se a esperança de mudança, logo, antes de tomá-lo como perdido, é preciso verificar se suas mudanças - neste item já previamente anunciadas - alteraram o caráter original da política avaliativa ou não. Em caso positivo, isso corroboraria a tese desta pesquisa, qual seja, a de que na prática a autoavaliação precisa avançar, pois em muitos casos não lograria um alcance eficaz, conforme dito nas considerações iniciais da pesquisa. Para tal, no item seguinte, se discute a implementação do Sinaes, com destaque para seus momentos de reconfiguração, os quais, por sua vez, delatam contradições.

\subsubsection{IMPLEMENTAÇÃO DO SINAES: MUDANÇAS E ENTRAVES}

Neste subitem se buscará problematizar o Sinaes, percebendo o nível de compromisso dessa política avaliativa com suas concepções formativas originais, explanadas anteriormente. Com isso, se pretende compor uma primeira aproximação da concepção de avaliação que emerge da prática, ressaltando, de antemão, que devido à própria extensão dessa política avaliativa, não se tem uma visão geral do impacto da avaliação da educação superior em todo o sistema educacional brasileiro.

Como visto antes, a proposta do Sinaes veio com a intenção de romper com velhas práticas avaliativas, as quais, em geral, reduziam a finalidade da política de avaliação ora a uma concepção voltada exclusivamente à regulação e, logo, controladora, ora a uma concepção formativa e emancipatória, essa última, antes, sem apoio do MEC e dos governos. Isso gerou a esperança de que o Sinaes lograsse um equilíbrio entre regulação e avaliação formativa, para que a regulação, em especial, não tivesse fim em si mesmo, mas, do contrário, 
se valesse de uma avaliação formativa e também fomentasse melhorias bem planejadas nas instituições.

O que se percebe, porém, é que o Sistema foi se reconfigurando durante sua implantação e distanciando-se, em parte, desse caráter tão idealizado pela academia e pelas IES. A começar pelo suporte de órgãos responsáveis, algumas mudanças ocorreram durante o processo. Ao Inep e a Conaes foram atribuídos encargos do Sinaes que eles não tinham suporte para atender. Com o passar do tempo, ainda que parte desses encargos tenha sido delegada a outros órgãos, esses ainda enfrentam dificuldades em relação a pessoal, por exemplo.

Houve a publicação do Decreto $n^{\circ}$ 5.773, de 9 de maio de 2006, popularmente conhecido como decreto ponte. Nele, entre outras considerações, as quais serão comentadas mais adiante neste item, se delegou algumas funções aos diferentes órgãos envolvidos com a educação superior, entre as quais, aquelas que se imaginariam próprias da Conaes enquanto órgão coordenativo e supervisor (BRASIL, 2006). À SESu, à Secretaria de Educação Profissional e Tecnológica - Setec, e à Secretaria de Educação a Distância - SEED foi requerido nesse Decreto decidir processos, estabelecer diretrizes e dar instruções relacionadas a procedimentos avaliativos. Além disso, no mesmo ano, foi publicada a Portaria MEC $n^{\circ}$ 1027, de 15 de maio de 2006 (BRASIL, 2006), agora regida pela Portaria Normativa $\mathrm{n}^{\circ}$ 40/2007, republicada em 2010 (BRASIL, 2010); e, com ela, criou-se a Comissão Técnica de Acompanhamento da Avaliação (CTAA). Esse órgão colegiado surgiu com a finalidade de acompanhar os processos de avaliação institucional externa e de avaliação dos cursos de graduação.

Dessas medidas se infere a possível percepção de que o Inep e a Conaes não seriam capazes de levar o Sinaes adiante sozinhos. Como indica Meneghel (2015), em entrevista já aludida, a Conaes "tinha atribuições que, depois, foram "perdidas" ou delegadas a outros pela legislação. E a Conaes foi perdendo, delegando... o decreto ponte é um pouco a prova disso, assim como a criação da CTAA.”. (p. 201). Ademais, segundo a mesma, a questão orçamentária influencia o trabalho dos membros da Comissão e dos funcionários do Inep. No que tange a esse último, seria difícil, segundo Meneghel, manter um corpo de servidores permanente nele, visto que os funcionários são atraídos por melhores salários de outros órgãos federais. Quanto à Conaes, até o momento, seus membros não recebem incentivo financeiro para atuarem, e acabam por exercer suas funções de forma voluntária. Sobre isso, Meneguel (2015) diz que 
[...] para exercerem seu papel como previsto - trabalhar as diretrizes, acompanhar os processos no detalhe -, as pessoas/especialistas precisam ter condições mínimas de se dedicar à avaliação, à análise de processos. Mas nunca houve o apoio adequado para fazer isso, uma vez que são voluntários. Note: os membros dos conselhos do CNE têm apoio; não recebem apenas a diária e a passagem. Os membros da CTAA, criada depois no Inep, têm o auxílio de avaliação educacional - e isso ocorre justamente porque não há como pedir aos membros da Conaes que trabalhem nisso de graça! A Conaes nunca teve esse apoio - não tinha e continua não tendo. Qual pode ser o comprometimento dos membros da Conaes? Claro que não é a remuneração que traz o comprometimento, mas sem ela não há nenhuma chance de os especialistas se dedicarem ao exame dos diversos processos e temas tratados. (p. 198).

Tendo suporte financeiro ou não àqueles que teriam que zelar pelo andamento da política do Sinaes, o fato é que a trajetória dessa política é marcada por mudanças, a partir das quais não se pode assegurar, a princípio, se foram boas ou ruins às IES. A começar pelo pilar da Avaliação dos Estudantes, tem-se que a Paideia, cujos objetivos foram mostrados no item anterior, não se tratava simplesmente de constatar desempenhos de estudantes, mas de avaliar tendências curriculares, dinâmicas formativas, relações interdisciplinares entre conjuntos de cursos, etc. No entanto, como mostra Dias Sobrinho (2010), ela não foi bem compreendida pelas IES e não teve boa aceitação do MEC, da mídia ou do Congresso Nacional. Desse modo, uma primeira reconfiguração do Sinaes seria a substituição da Paideia pelo Exame Nacional de Desempenho dos Estudantes - Enade - ainda em 2004.

Era como se a população estivesse acostumada com a prática controladora de tal maneira que uma avaliação com os moldes da Paideia os assustava. Quando comentava sobre a criação do Enade durante a entrevista aludida anteriormente, Meneghel (2015), por exemplo, até compara a instituição do exame a um "mal necessário" para atender o gosto da sociedade pelo ENC:

Quanto ao Enade, enquanto recurso para avaliar cursos, foi incorporado à proposta quase como "um mal necessário". Previa-se uma reação muito negativa da sociedade e da mídia em geral se um exame para os estudantes deixasse de existir, e houve certo consenso que, independente da contribuição ao sistema, acabar com o ENC sem colocar outra coisa no lugar seria ruim - essa repercussão abalaria o restante da proposta. E se imaginava que, algum dia, a avaliação institucional e a de cursos ficariam tão fortes que o Enade poderia deixar de existir. (p. 192).

Segundo a Coordenadora Geral de Qualidade da Daes, como visto, esperava-se que os outros pilares do Sinaes sobrepusessem o Enade e que, por conseguinte, esse último deixasse 
de existir com o passar do tempo, contudo, isso nunca aconteceu. O Enade, desde sua instituição, teve como objetivo aferir

\begin{abstract}
[...] o desempenho dos estudantes em relação aos conteúdos programáticos previstos nas diretrizes curriculares do respectivo curso de graduação, suas habilidades para ajustamento às exigências decorrentes da evolução do conhecimento e suas competências para compreender temas exteriores ao âmbito específico de sua profissão, ligados à realidade brasileira e mundial e a outras áreas do conhecimento. (BRASIL, 2004a, art. $5^{\circ}$ ).
\end{abstract}

Para alcançar esse objetivo, por sua vez, esse pilar avaliativo contaria com os seguintes instrumentos: (i) uma prova, (ii) um questionário de impressões dos estudantes sobre a prova, (iii) um questionário do estudante e (iv) um questionário do coordenador(a) do curso.

Os questionários destinados aos estudantes, preenchidos online, apresentam um formado que permite ao respondente indicar seu grau de concordância com determinada assertiva em uma escala que vai do 1 (Discordo totalmente) ao 6 (Concordo totalmente). O teor desses questionários, por sua vez, pretende captar a percepção dos discentes sobre situações do processo de aprendizagem, bem como habilidades e competências das Diretrizes Curriculares Nacionais. Não obstante, boa parte das assertivas concentra-se em captar a percepção do estudante sobre seus professores, em uma espécie de avaliação do docente pelo discente. (GONÇALVES, SOUSA, 2016) Nas mãos desse último encontra-se, pois, o poder de avaliar os docentes em vários aspectos, enquanto ao professor só lhe é dado voz na autoavaliação institucional. O questionário destinado aos coordenadores de curso, por sua vez, apresentam perguntas bastante similares às feitas aos estudantes, contudo, a perspectiva nesse outro contexto é a da visão do responsável por coordenar a implantação do projeto pedagógico do curso.

Já a prova, conta com um componente de formação geral para os estudantes de todos os cursos; e outro específico para cada área, o que indica que para o Sinaes uma formação de qualidade não passaria só pela aquisição de competências específicas à formação de um profissional determinado. A parte geral foi contemplada no exame de 2015 com dez questões - duas discursivas e oito de múltipla escolha, envolvendo situações-problema e estudos de caso. Todas podem versar sobre os seguintes objetos de conhecimento: (i) cultura e arte; (ii) inovação tecnológica; (iii) ciência, tecnologia e sociedade; (iv) democracia, ética e cidadania; (v) ecologia; (vi) globalização e política internacional; (vii) políticas públicas: educação, habitação, saneamento, saúde, transporte, segurança, defesa e questões ambientais; (viii) 
relações de trabalho; (ix) responsabilidade social: setor público, privado e terceiro setor; (x) sociodiversidade e multiculturalismo: violência, tolerância/intolerância, inclusão/exclusão e relações de gênero; (xi) tecnologias de informação e comunicação; e (xii) vida urbana e rural. (BRASIL/Inep, 2015). A partir desses 12 objetos de conhecimento dos mais diversos, o Enade extrairia elementos que são integrantes do perfil profissional de um cidadão:

[...] letramento crítico; atitude ética; comprometimento e responsabilidade sociais; compreensão de temas que transcendam ao ambiente próprio de sua formação, relevantes para a realidade social; espírito científico, humanístico e reflexivo; capacidade de análise crítica e integradora da realidade; e aptidão para socializar conhecimentos com públicos diferenciados e em vários contextos. (BRASIL/Inep, 2015, art. $3^{\circ}$ ).

Assim como a proposta da Paideia, portanto, a do Enade não reduziria o estudante a uma força de trabalho para o mercado de trabalho; e não faria da prova um checklist de aptidões de determinada profissão. Contudo, essa avaliação, que já é fruto de uma reconfiguração do Sinaes, encerraria algumas mudanças internas, entre as quais, as que influenciariam o Sistema como um todo.

O Enade, a princípio, era amostral; e o exame era aplicado aos estudantes ingressantes e concluintes considerados apitos para participarem em determinado ciclo avaliativo. Consideravam-se estudantes habilitados ingressantes aqueles que tinham iniciado o respectivo curso com matrícula no ano da aplicação do exame ou que tinham concluído até $25 \%$ (vinte e cinco por cento) da carga horária mínima do currículo do curso. E consideravam-se estudantes concluintes, em 2014, aqueles que tinham expectativa de conclusão do curso até aproximadamente o mês de julho do ano subsequente à aplicação do exame, assim como aqueles que tiverem concluído mais de $80 \%$ (oitenta por cento) da carga horária mínima do currículo do curso da IES. (BRASIL, 2014).

Em 2009 e 2010, respectivamente, por sua vez, o exame deixou de ser amostral e passou a ser censitário, além de o estudante ingressante não mais necessitar fazer a prova especifica, senão apenas a geral, a qual passaria a ser realizada com base na matriz de referência do Exame Nacional do Ensino Médio (Enem) ${ }^{59}$. (BARREYRO; ROTHEN, 2014). Para esses autores, tais mudanças indicavam um retorno ao Exame Nacional de Cursos. Segundo eles,

${ }^{59}$ Os estudantes que fizeram o Enem estão dispensados da primeira prova do Enade. 
[...] do ENADE inicial fica apenas a prova de conhecimentos específicos (denominada prova específica na Portaria), pois a prova geral será um ENEM-ADE, (ENADE com a matriz do ENEM). No entanto, como prova de conhecimentos específicos já era o ENC-Provão, percebe-se também nessa nova mudança o retorno do Provão: uma prova de conhecimentos específicos aplicada a todos os alunos concluintes dos cursos avaliados. (p. 72).

Para Barreyro e Rothen (2014), os quais, no tópico anterior, já tinham sido citados como pesquisadores que fazem uma relação direta entre os pilares do Sinaes e elementos constituintes das avaliações passadas, o Enade teria relação direta com o ENC. No entanto, percebe-se que mesmo com certas semelhanças, há diferenças fundamentais entre os dois processos avaliativos. Conforme Dias Sobrinho (2010), o distanciamento entre ambas as avaliações encontra-se, justamente,

[...] nas distintas concepções de avaliação estática, do Provão, e dinâmica, do ENADE. O Provão era uma avaliação estática: uma prova aplicada aos alunos no final do curso colhia respostas pontuais, cuja soma de acertos e descontos dos erros resultava em pontuações e classificações, sem oferecer feedback. Era essencialmente uma avaliação de produto, somativa. Já o ENADE se propõe como avaliação dinâmica, incorporando a noção de mudança e desenvolvimento do aluno em seu percurso formativo. Nessa perspectiva, o processo ganha proeminência sobre o resultado final isolado. Entre uma e outra aplicação do exame, o aluno tem oportunidade de superar suas deficiências, desenvolver suas habilidades cognitivas e aplicálas em novas situações. (p. 213).

O conjunto dos resultados dos questionários e dos exames, sob essas condições, possibilitaria a construção de um panorama sobre as condições e processos de aprendizagem das áreas avaliadas em todo o país. Esses, eram sistematizados apenas no chamado Conceito Enade, organizado em uma escala de cinco níveis. Contudo, gradativamente, foram servindo a mais mudanças no Enade e no sistema, como um todo. A partir de 2005, uma série de índices foram sendo criados tendo como base principal os resultados do Enade.

No ano em questão, o Indicador de Diferença entre os Desempenhos Observado e Esperado (IDD) foi instituído. Esse, comparando os resultados da prova aplicada aos ingressantes e da aplicada aos concluintes, verificaria o que a instituição agregou de conhecimento ao estudante, o que é algo consideravelmente importante.

No final do primeiro mandato do governo de Luís Inácio Lula da Silva, no entanto, foi publicado o Decreto $\mathrm{n}^{\circ} 5.773$, de 9 de maio de 2006 (BRASIL, 2006), citado anteriormente, e, 
com ele, estabeleceu-se uma espécie de "ponte" entre avaliação e regulação ${ }^{60}$. Tal decreto se converteu em um "marco, por ter explicitado as funções de avaliação e de regulação e por ter definido a de supervisão do sistema, o que enfatizou a fiscalização." (BARREYRO; ROTHEN, 2014, p. 69). Representando uma nova fase do Sistema Nacional de Avaliação da Educação Superior, o decreto fez com que o Enade ganhasse destaque em relação aos demais momentos avaliativos ao indicar que o governo acenaria para modificações no papel do Estado quanto aos processos de avaliação da educação superior. (RIBEIRO, 2012). Com base nele, e em nome da regulação, mais índices foram criados, os quais, em conjunto e grande quantidade, abalaram o equilíbrio entre os três pilares do sistema.

Em 2008, com a reedição da Portaria $n^{\circ} 40$ no ano anterior, dois novos indicadores foram inseridos no contexto do Enade: o Índice Geral de Cursos (IGC) da Instituição de Educação Superior e o Conceito Preliminar de Curso (CPC). O IGC é composto pelas médias ponderadas dos CPC e das notas que a Capes atribui aos programas de pós-graduação das instituições de educação superior avaliadas; e seu resultado é amplamente divulgado, sendo feito, a partir dele, rankings das IES. O Conceito Preliminar de Curso, por sua vez, é composto pelos resultados do Enade, pelos dados do Censo da Educação Superior e por outros dados de cadastros do Ministério da Educaçaõ; e seu resultado, serve, entre outras considerações, à possível dispensa da avaliação in loco realizada em virtude da Avaliação de Cursos.

Como visto no subitem anterior, a lei do Sinaes deixa clara que a visita dos avaliadores especializados quando da Avaliação de Cursos era indispensável e constituía o momento fundamental desse pilar. Mas, contraditoriamente, quando o CPC for considerado satisfatório, as IES podem ser dispensadas da visita, configurando uma subversão sem precedentes ao princípio da harmonia entre as partes constituintes do Sistema Nacional de Avaliação da Educação Superior.

Como mostram Bittencourt; Casartelli e Rodrigues (2009), 40\% da nota do índice CPC vem do Enade, 30\% vem do IDD (Indicador de Diferença dentre os Desempenhos Observado e Esperado do estudante), $12 \%$ do percentual de doutores na instituição de educação superior e $8 \%$ dos recursos didáticos e $3 \%$ das instalações e infraestrutura. Por conseguinte, encontra-se na avaliação do estudante e no poder atribuído a esse agente institucional a dispensa ou não de visita de avaliadores; e isso é preocupante. Como mostra Gontijo (2014, p. 98), “num contexto em que as avaliações externas definem a continuidade

60 Essa "ponte" fez com que o Decreto fosse popularmente conhecido como Decreto Ponte. 
da oferta do curso e o maior "peso" dessa avaliação, preponderantemente, centrado na figura do estudante, o trabalho do professor pode passar a ser o de ensinar/preparar para a prova." (p. 98).

Instaura-se, nesse sentido, uma contradição na política do Sistema Nacional de Avaliação da Educação Superior: essa institui um pilar - o ACG -, que é praticamente substituível por um dos indicadores de qualidade de outro pilar - o Enade -. Não suficiente, outra contradição, talvez até mais abrangente, é o fato de se definir o Sinaes como uma política formativa, emancipadora, que pressupõe a autonomia das IES, entre outras considerações, mas dar a um exame e a apenas um agente institucional - o estudante tamanho poder. Diante de tanta visibilidade ao Enade, qual o espaço dos outros pilares e especificamente da autoavaliação, objeto desta pesquisa?

Como mostra Rodrigues (2015, p.174), com a emergência desses índices e sua grande publicização, "os resultados têm ocupado a centralidade da política de avaliação. Portanto, os resultados do Sinaes têm sido utilizados com vistas ao ranqueamento e à competição, instalando-se, assim, a lógica capitalista na oferta dos serviços educacionais.”. Se a política do Sinaes voltar-se completamente ao Enade e a todos os aspectos regulatórios que os resultados de uma avaliação podem subsidiar, corre-se o risco de a política limitar-se à regulação e esvaziar-se formativamente. Para Barreyro e Rothen (2014), por exemplo, esse esvaziamento já até aconteceu:

A emergência dos índices surpreendeu a gregos e troianos, gerando inúmeras críticas, seja por questionamentos técnicos na construção do indicador, seja pela descaracterização do SINAES. Poucas vozes defenderam a nova proposta. O Conceito mudou a implementação do SINAES, limitando as visitas in loco aos cursos que obtiveram um conceito preliminar menor que 3 , o que gerou a diminuição de 3.000 visitas previstas por ano para 1.800 . Tal motivo, embora louvável no ponto de vista administrativo, não o é para o objetivo de melhoria de qualidade, pois, ao se aligeirar os processos de avaliação de cursos, perdeu-se o caráter formativo da avaliação. (p. 70).

Conforme Meneghel (2015), o que fora urgente desde a criação da política do Sinaes foi a prática da regulação e tudo o que ela podia subsidiar; se usar a regulação como motor de toda a política avaliativa, por sua vez, é o correto, isso já não se pode afirmar. Como a mesma disse:

O que era urgente naquele momento? A regulação. Eram necessários padrões mínimos para avançar em outras políticas - a de expansão, a de financiamento, dentre outras. Os resultados da avaliação, mediados pela 
regulação, têm "puxado" os processos realizados pelo Inep. Isso está certo ou está errado? Bem, isso tem sido o possível, desde aquela época. (p. 196).

Os processos “puxados” pelo Exame Nacional de Avaliação de Desempenho dos Estudantes são vários. O protagonismo que o Enade ganhou em virtude da criação dos índices é tão marcante que, inclusive, a adesão das IES a algumas políticas públicas de educação está sujeita aos resultados delas no Enade e nos índices provenientes dele - CPC e IGC. No quadro 6 a seguir, por exemplo, se visualiza as atuais políticas orientadas pelos resultados do exame.

Quadro 6: Políticas para educação superior orientadas pelo Enade, CPC e IGC

\begin{tabular}{|c|c|}
\hline Política & Vínculo legal aos indicadores \\
\hline Programa Universidade para Todos (ProUni) & $\begin{array}{l}\text { Lei } \mathrm{n}^{\circ} \quad 11.096 / 2005 ; \\
24 / 2010\left(\operatorname{art} 6^{\circ}\right)\end{array}$ \\
\hline $\begin{array}{l}\text { Fundo de Financiamento ao Estudante de } \\
\text { Ensino Superior - FIES }\end{array}$ & $\begin{array}{l}\text { Lei } n^{\circ} 11.552 / 2007\left(\operatorname{art} 1^{\circ}\right) \text {; Lei } 12.202 / 2010(\operatorname{art} \\
\left.1^{\circ}\right) ; \text { Portaria Normativa } n^{\circ} 1 / 2010\left(\operatorname{art} 1^{\circ}\right)\end{array}$ \\
\hline $\begin{array}{l}\text { Programa de Melhoria do Ensino das } \\
\text { Instituições de Educação Superior - Programa } \\
\text { IES - MEC/BNDES e Programa de Estímulo à } \\
\text { Reestruturação e ao Fortalecimento das } \\
\text { Instituições de Ensino Superior (PROIES) }\end{array}$ & $\begin{array}{l}\text { Lei } \mathrm{n}^{\circ} 12.688 / 2012 \text {; Portaria Normativa } 14 \text {, de } \\
\text { 24/09/2009 c/c Portaria Normativa 14/2009 (art } \\
2^{\circ} \text { ); Portaria Normativa 26/2012 (art } 3^{\circ} \text { ) }\end{array}$ \\
\hline $\begin{array}{l}\text { Programa Nacional de Acesso ao Ensino } \\
\text { Técnico e Emprego - PRONATEC }\end{array}$ & $\begin{array}{l}\text { Lei } 12.513 / 2011 \text {; Portaria MEC } n^{\circ} 160 / 2013 \text { (art } \\
9^{\circ} \text { ) }\end{array}$ \\
\hline $\begin{array}{l}\text { Política Nacional de Formação de Profissionais } \\
\text { do Magistério da Educação Básica (PARFOR, } \\
\text { Prodocência e PIBID) }\end{array}$ & Decreto $^{\circ}{ }^{6} 6.755 / 2009 ;$ Decreto $n^{\circ} 7.219 / 2010$ \\
\hline Universidade Aberta do Brasil - UaB & Decreto 5.800/2006 \\
\hline $\begin{array}{l}\text { Programa de Apoio a Planos de Reestruturação } \\
\text { e Expansão das Universidades Federais - } \\
\text { REUNI }\end{array}$ & Decreto $^{\circ} 6.096 / 2007$ \\
\hline
\end{tabular}

Fonte: Sousa; Fernandes (2015, p.9).

Obviamente, qualquer política pública precisa de critérios que limitem seu alcance. Assim, o quadro 6, elaborado por Sousa e Fernandes (2015), apenas corrobora o destaque maior dado ao Enade no processo gradual de reconfiguração do Sinaes. A questão é que por trás desse destaque pode estar a perda do aspecto formativo. De acordo com Garcia; Espindola e Sordi (2011, p. 28), a

[...] centralidade deste componente, justificada pela necessidade de prestação de contas, implica em ações pouco formativas por parte de algumas instituições que voltam suas atenções à capacitação do estudante para 0 exame e não para a formação integral, sólida, de preparação não apenas técnica e profissional, mas fundamentalmente social ética e política. 
O Enade, como componente do Sinaes, deveria ter seus resultados analisados em conjunto com os outros componentes da avaliação - Avaliação de Cursos e Avaliação Institucional, a qual abarca a autoavaliação. No entanto, os rankings e o foco nos resultados voltaram; e a Avaliação de Cursos já nem é realizada como na proposta original, já que subsumida pelo Enade. Nesse contexto, o que dizer da avaliação que viria para inovar a política avaliativa e dar voz às IES? Políticas de caráter controlador não dão abertura à autoavaliação institucional; e percebendo que o pilar da Avaliação de Cursos já foi, em certa medida, suprimido pelo Enade, o pilar da Avaliação Institucional e, especificamente, a autoavaliação não poderia também o ser?

Como indica o representante da Conaes, na entrevista concedida, "a avaliação externa, o olhar externo é importante? É lógico que é importante. Mas aquele olhar que você vira pra você mesmo, descobre você mesmo, esse é o mais enriquecedor, não tenho dúvida disso." (CO, informação verbal). E concordando com a afirmativa do entrevistado, acredita-se que a autoavaliação institucional não deve ser suprida por nenhuma outra avaliação ou, no caso, pilar avaliativo.

A avaliação das Instituições da Educação Superior (Avalies), a qual seria o centro de referência e articulação do sistema de avaliação, é desenvolvida em dois momentos - a autoavaliação, realizada pelas Comissões Próprias de Avaliação, e a avaliação externa, realizada pelas comissões externas designadas pelo Inep. Por muitos anos esse pilar avaliativo deveria considerar, em ambas as avaliações, as dez dimensões já citadas no item anterior; no entanto, como mostra Ribeiro (2011), essas encerram um contrassenso. As dez dimensões parecem mais relacionadas às instituições de educação superior privadas, de pequeno porte, enquanto, ao mesmo tempo, os instrumentos construídos com base nelas pareciam tomar como referência geral as universidades de grande porte. "A adoção de certos critérios e, sobretudo, as exigências quanto à produção de conhecimento e regime de trabalho do corpo docente, por exemplo, indicam claramente esta tendência.”. (RIBEIRO, 2011, p. 64). Cada dimensão possui, no caso da avaliação institucional externa, pesos que variam de 5 a 35 e que subsidiariam o chamado "Conceito Institucional” de cada IES. Observe no quadro 7, a seguir, os pesos e indicadores respectivos de cada dimensão avaliativa e sob quais características recai peso maior. 
Quadro 7: Dimensões, indicadores e pesos referentes à avaliação institucional externa

\begin{tabular}{|c|c|c|}
\hline \multicolumn{3}{|c|}{ (continua) } \\
\hline 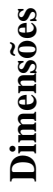 & Indicadores & 管 \\
\hline \multirow[b]{2}{*}{1} & $\begin{array}{l}\text { 1.1 Implementação do PDI, considerando as metas e as ações institucionais previstas e a } \\
\text { estrutura e os procedimentos administrativos. }\end{array}$ & \multirow{2}{*}{5} \\
\hline & $\begin{array}{l}\text { 1.2. Articulação entre o PDI e os processos de avaliação institucional autoavaliação e } \\
\text { avaliações externas). }\end{array}$ & \\
\hline \multirow{7}{*}{2} & 2.1. Coerência das políticas de ensino, pesquisa e extensão com os documentos oficiais. & \multirow{7}{*}{35} \\
\hline & $\begin{array}{l}\text { 2.2. Políticas institucionais para cursos de graduação (bacharelados, licenciaturas e de } \\
\text { tecnologia) e cursos sequenciais (quando for o caso), na modalidade presencial, e suas } \\
\text { formas de operacionalização. }\end{array}$ & \\
\hline & $\begin{array}{l}\text { 2.3. Políticas institucionais para cursos de graduação (bacharelados, licenciaturas e de } \\
\text { tecnologia) e cursos sequenciais (quando for o caso), na modalidade a distância, e suas } \\
\text { formas de operacionalização (indicador exclusivo para IES credenciada para modalidade a } \\
\text { distância). }\end{array}$ & \\
\hline & $\begin{array}{l}\text { 2.4. Políticas institucionais para cursos de pós -graduação (lato sensu e stricto sensu), na } \\
\text { modalidade presencial, e suas formas de operacionalização (igual forma para faculdades, } \\
\text { universidades e centros universitários). }\end{array}$ & \\
\hline & $\begin{array}{l}\text { 2.5. Políticas institucionais para cursos de pós-graduação lato sensu e stricto sensu na } \\
\text { modalidade a distância, e suas formas de operacionalização (indicador exclusivo para IES } \\
\text { credenciada para modalidade a distância). }\end{array}$ & \\
\hline & $\begin{array}{l}\text { 2.6. Políticas institucionais de pesquisa e de iniciação científica e suas formas de } \\
\text { operacionalização. }\end{array}$ & \\
\hline & $\begin{array}{l}\text { 2.7. Políticas institucionais de extensão e formas de sua operacionalização, com ênfase à } \\
\text { formação inicial e continuada e à relevância social. }\end{array}$ & \\
\hline \multirow{4}{*}{3} & $\begin{array}{l}\text { 3.1. Coerência das ações de responsabilidade social com as políticas constantes dos } \\
\text { documentos oficiais. }\end{array}$ & \multirow{4}{*}{5} \\
\hline & 3.2. Relações da IES com a sociedade; setor público, setor privado e mercado de trabalho. & \\
\hline & 3.3. Relações da IES com a sociedade: inclusão social. & \\
\hline & $\begin{array}{l}\text { 3.4. Relações da IES com a sociedade: defesa do meio ambiente, da memória cultural, da } \\
\text { produção artística e do patrimônio cultural. }\end{array}$ & \\
\hline \multirow{3}{*}{4} & $\begin{array}{l}\text { 4.1. Coerência das ações de comunicação com a sociedade com as políticas constantes dos } \\
\text { documentos oficiais. }\end{array}$ & \multirow{3}{*}{5} \\
\hline & 4.2. Comunicação interna e externa. & \\
\hline & 4.3. Ouvidoria. & \\
\hline \multirow{6}{*}{5} & $\begin{array}{l}\text { 5.1. Coerência das políticas de pessoal, de carreiras do corpo docente e corpo técnico- } \\
\text { administrativo, seu aperfeiçoamento, seu desenvolvimento profissional e suas condições } \\
\text { de trabalho com as políticas firmadas em documentos oficiais. }\end{array}$ & \multirow{6}{*}{20} \\
\hline & 5.2. Formação do corpo docente. & \\
\hline & 5.3. Condições institucionais para os docentes. & \\
\hline & 5.4. Condições institucionais para o corpo técnico-administrativo. & \\
\hline & $\begin{array}{l}\text { 5.5. Condições institucionais para o corpo técnico-administrativo. Conceito referencial } \\
\text { mínimo de qualidade: Quando o perfil (formação e experiência) e as políticas de } \\
\text { capacitação do corpo técnico administrativo estão adequados às políticas constantes dos } \\
\text { documentos oficiais da IES. Além disso, o Plano de Cargos e Salários, homologado por } \\
\text { órgão do Ministério do Trabalho e Emprego, está implementado e difundido. }\end{array}$ & \\
\hline & $\begin{array}{l}\text { 5.6. Formação do corpo de tutores presenciais e suas condições institucionais (indicador } \\
\text { exclusivo para IES credenciada para modalidade a distância - EAD). }\end{array}$ & \\
\hline
\end{tabular}


Quadro 7: Dimensões, indicadores e pesos referentes à avaliação institucional externa

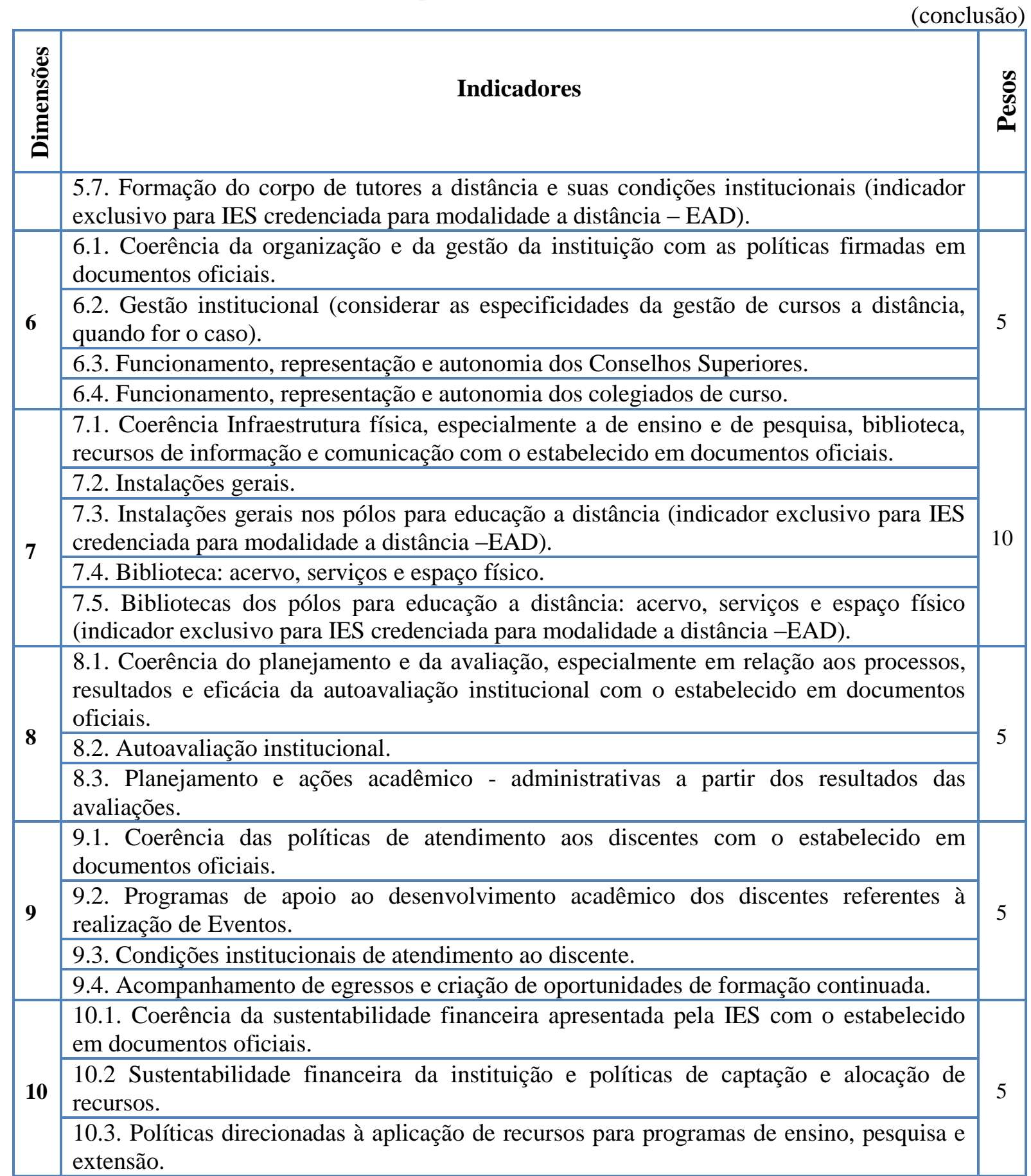

Fonte: Elaboração própria com base em Brasil (2010).

Como visto no quadro 7 ilustrado, o olhar sob as dimensões pretendia avaliar a instituição de educação superior de uma maneira ampla, levando em consideração desde a infraestrutura até a missão e função social dessa. Os pesos atribuídos, no entanto, são distintos em cada uma, do que se infere que para a política do Sinaes algumas dimensões são mais indutoras de qualidade que outras. As dimensões de número 2 e 5, por exemplo, têm, respectivamente, os maiores pesos, a saber: 35 e 20, e referem-se às políticas institucionais 
para o ensino, pesquisa, extensão e pós-graduação, bem como às políticas para a carreira docente e do corpo técnico-administrativo. Como visto no capítulo 1, no entanto, são sob as instituições como as universidades, em geral públicas, que recaem as maiores exigências quanto à especialização do quadro de professores e quanto à existência obrigatória da tríade pesquisa-ensino-extensão.

Coincidência ou não, no que tange aos relatórios de autoavaliação institucional produzidos durante esse processo tem-se que são as universidades as que apresentam relatos mais completos em termos de dimensões, ainda que, de modo geral, há muitas falhas nos relatórios em todo o país. Segundo pesquisa levantada pelo Inep com base em 172 relatórios de autoavaliação produzidos por Comissões Próprias de Avaliação de diversas IES, identificou-se, entre outras questões, que: (i) apenas 12,2\% dos relatórios analisados foram considerados completos nas 10 dimensões definidas até 2013 para a avaliação; (ii) as universidades apresentam maior percentual de relatórios completos, seguidas dos centros universitários e das faculdades; (iii) a dimensão 8 foi considerada completa em pouco mais de 25\% dos relatórios; (iv) as dimensões 1, 4, 6, 9 e 10 tiveram mais de 40\% dos relatórios apenas com gráficos ou tabelas sem acompanhamento de análise ou interpretação; e (v) as dimensões 2, 3, 6 e 10 tiveram mais de 25\% dos relatórios sem informação. (BRASIL/Inep, 2011).

A pesquisa de Leite $(2008)^{61}$, realizada com 899 CPA de instituições brasileiras com até 500 estudantes, já havia chegado, por sua vez, a resultados análogos. Ela mostrou que apesar das Comissões terem sido efetivamente construídas em conformidade com o estabelecido pelo Sinaes, seu trabalho materializa-se em relatórios pouco críticos, os quais apenas cumprem a obrigação legal. Além disso, em contrapartida, as CPA almejavam, de acordo com o autor: (i) qualificação para os coordenadores da Comissão; (ii) presença de um orientador remunerado; (iii) mais apoio por parte do MEC/Inep/Conaes; (iv) cursos para formação e produção de documentação técnica; e (v) mais momentos de integração entre os membros.

\footnotetext{
${ }^{61}$ Essa pesquisa, publicada no ano de 2008, foi realizada em 2007. Tendo como amostra as instituições de educação superior brasileiras com até 500 estudantes, o estudo abarcou 50,62\% do total de instituições do Brasil à época em questão, as quais tinham as mais diversas denominações: faculdade integrada, faculdade isolada, escola e/ou instituto, centro de educação tecnológica, centro federal de educação tecnológica, faculdade de tecnologia, centro universitário. Em um primeiro momento da pesquisa, a autora em questão, juntamente com uma equipe especializada, examinou 256 relatórios de autoavaliação institucional. E já em um segundo momento, 899 Comissões Próprias de Avaliação foram ouvidas por meio de questionário eletrônico aplicado.
} 
Como se Comissões Próprias de Avaliação mal preparadas e relatórios incompletos não fossem o bastante, tem-se ainda que a pesquisa encomendada pela própria Conaes, na qual se selecionou 218 relatórios de autoavaliação entre os 2.063 das instituições que apresentaram esses entre os dias 25 de março a 2 de abril de 2013, vem endossar esse panorama e identificar mais um problema da implementação da autoavaliação. A pesquisa concluiu que $33 \%$ dos relatórios entregues não contemplaram nenhuma das dez dimensões previstas e que nenhum relatório informou se se tratava de uma avaliação parcial ou integral da instituição. (CONAES, 2013).

Um processo avaliativo funcionando desse modo, obviamente não ganharia o destaque e prioridade devida. Surpreendentemente, enquanto mudanças na configuração do Enade ocorriam desde o inicio do Sistema Nacional de Avaliação da Educação Superior, na avaliação institucional esperou-se 10 anos para se tomar alguma atitude mais substancial. A partir da Portaria $n^{\circ}$ 92, de 31 de janeiro de 2014, passou-se, entre outras considerações, a se considerar não mais as dez dimensões para a avaliação, senão cinco eixos, os quais reorganizam as referidas dimensões, conforme comentado nas considerações iniciais desta pesquisa. São eles: o (i) eixo 1: Planejamento e Avaliação Institucional, que contém a dimensão 8; (ii) o eixo 2: Desenvolvimento Institucional, com a dimensão 1 e a 3; (iii) o eixo 3: Políticas Acadêmicas, onde se inserem as dimensões 2, 4 e 9; (iv) o eixo 4: Políticas de Gestão, contendo a dimensão 5, 6 e a 10; e (v) o eixo 5, com a dimensão 7. (BRASIL/MEC, 2014).

Esses eixos ordenam, de maneira melhor e mais claramente, as dimensões e passaram a ser utilizados, a partir de 2015, na avaliação externa - pela Comissão de Avaliação Externa designada pelo Inep segundo diretrizes da Conaes - e na autoavaliação - pela Comissão Própria de Avaliação de cada instituição de educação superior. Como se verá no quadro 8, em seguida, o qual explana os cinco referidos eixos instituídos, bem como os respectivos indicadores desses, há, certamente, um esforço em se sintetizar mais o processo de avaliação institucional interna e externa. Tanto para a autoavaliação como para a avaliação externa, esses são os indicadores que, recentemente, passam a servir de base à avaliação, os quais são mais precisos e sintéticos que os indicadores da avaliação externa, explanados no quadro 7 , anteriormente. 
Quadro 8: Indicadores dos cinco eixos da avaliação institucional no Sinaes

(continua)

\begin{tabular}{|c|c|}
\hline ஜ) & Indicadores \\
\hline 1 & $\begin{array}{l}\text { - Evolução institucional a partir dos processos de Planejamento e Avaliação Institucional. } \\
\text { - } \quad \text { Projeto/processo de auto avaliação institucional. } \\
\text { - } \quad \text { Auto avaliação institucional: participação da comunidade acadêmica. } \\
\text { - Auto avaliação institucional e avaliações externas: análise e divulgação dos resultados. } \\
\text { - } \quad \text { Elaboraçacaão do relatório de autoavaliação. }\end{array}$ \\
\hline 2 & $\begin{array}{l}\text { - Missão institucional, metas e objetivos do PDI. } \\
\text { - Coerência entre o PDI e as atividades de ensino de graduação e de pós-graduação } \\
\text { - Cuerência entre o PDI e as atividades de pesquisa/iniciação científica, tecnológica, artística } \\
\text { - Coerência entre o PDI e as atividades de pesquisa/iniciação científica, tecnológica, artística e } \\
\text { cultural } \\
\text { - Coerência entre o PDI e as atividades e as ações no que se refere à diversidade, ao meio } \\
\text { ambiente, à memória cultural, à produção artística e ao patrimônio cultural } \\
\text { - Coerência entre o PDI e as ações institucionais voltadas para o desenvolvimento econômico e } \\
\text { - Cocial } \\
\text { - Coerência entre o PDI e ações de responsabilidade social: inclusão social } \\
\text { - Inualdade étnico-racial } \\
\text { Internacionalização: coerência entre o PDI e as ações institucionais }\end{array}$ \\
\hline 3 & $\begin{array}{l}\text { - Políticas de ensino e ações acadêmico-administrativas para os cursos de graduação } \\
\text { - Políticas de ensino e ações acadêmico administrativas para os cursos de pós-graduação } \\
\text { - Prticto sensu } \\
\text { Políticas de ensino e ações acadêmico administrativas para os cursos de pós-graduação lato } \\
\text { - Políticas institucionais e ações acadêmico administrativas para a pesquisa ou iniciação } \\
\text { científica, tecnológica, artística e cultural } \\
\text { - Políticas institucionais e ações acadêmico-administrativas para a extensão } \\
\text { - Políticas institucionais e ações de estímulo relacionadas à difusão das produções } \\
\text { - Comeâmicas: científica, didático-pedagógica, tecnológica, artística e cultural } \\
\text { - Comunicaçãão da IES com a comunidade externa } \\
\text { - Programas de atendimento aos estudantes } \\
\text { - Programas de apoio à realização de eventos internos, externos e à produção discente } \\
\text { - Política e ações de acompanhamento dos egressos } \\
\text { - Atuação dos egressos da IES no ambiente socioeconômico } \\
\text { Inovação tecnológica e produtividade intelectual: coerência entre o PDI e as ações } \\
\text { institucionais }\end{array}$ \\
\hline 4 & $\begin{array}{l}\text { - Política de formação e capacitação docente } \\
\text { - } \quad \text { Política de formação e capacitação do corpo técnico-administrativo } \\
\text { - Sestão institucional } \\
\text { - Sistema de registro acadêmico } \\
\text { - } \text { Relação entre o planejamento financeiro (orçamento) e gestão institucional } \\
\text { - Coerência entre plano de carreira e a gestão do corpo docente } \\
\text { - Coerência entre o plano de carreira e a gestão do corpo técnico-administrativo }\end{array}$ \\
\hline
\end{tabular}


Quadro 8: Indicadores dos cinco eixos da avaliação institucional no Sinaes

\begin{tabular}{|c|c|}
\hline : & Indicadores \\
\hline 5 & $\begin{array}{l}\text { - Instalações administrativas } \\
\text { - Salas de aula } \\
\text { - } \text { Suditório(s) } \\
\text { - } \text { Espaços para atendimento aos alunos } \\
\text { - Infraestrutura para CPA } \\
\text { - } \text { Instalações sanitárias } \\
\text { - Biblioteca: infraestrutura física } \\
\text { - Biblioteca: serviços e informatização } \\
\text { - } \text { - Siblioteca: plano de atualização do acervo } \\
\text { - Recursos de Tecnologias de Informação e Comunicação } \\
\text { - Laboratórios, ambientes e cenários para práticas didáticas: infraestrutura física } \\
\text { - Laboratórios, ambientes e cenários para práticas didáticas: serviços }\end{array}$ \\
\hline
\end{tabular}

Fonte: Elaboração própria com base em Brasil/MEC (2014).

Essa nova configuração da avaliação institucional, em eixos com respectivos indicadores, representada no quadro 8, alinha o processo de avaliação externa ao da autoavaliação, visto que serve a ambos. E essa primeira grande mudança nesse pilar avaliativo já começa a sugerir que agora haveria uma preocupação maior para que o conceito atingido na avaliação externa ou, sobretudo, o relatório produzido na autoavaliação a partir desses, não se esgotassem em si mesmo.

No mesmo mês e ano e com base nessa nova configuração em eixos, por sua vez, instituiu-se o documento "Instrumento de avaliação institucional externa" (BRASIL/Inep/Daes, 2014), no qual, entre outras considerações, enfatiza-se a orientação para que os avaliadores da avaliação institucional externa analisem os relatórios de autoavaliação no momento em que estiverem avaliando a IES no eixo 1 . Esse eixo, como visto no quadro 8 , considera a dimensão 8 (Planejamento e Avaliação), ficando estabelecido sob seu escopo que se deve fazer descrição e identificação “dos principais elementos do processo avaliativo da IES em relação ao seu PDI, aos relatórios elaborados pela CPA e aos demais documentos institucionais avaliativos do período que constituiu o objeto de avaliação.”. (BRASIL/Inep/Daes, 2014, p. 5). A partir de uma escala de 1 a 5, os avaliadores devem observar os seguintes quesitos nos relatórios de autoavaliação, segundo o quadro a seguir: 
Quadro 9: Quesitos analisados no relatório de autoavaliação pelos avaliadores institucionais externos

\begin{tabular}{|c|c|}
\hline \multirow{5}{*}{ 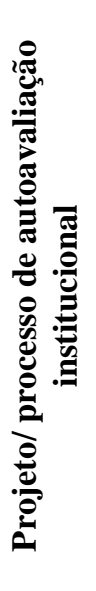 } & 1-Quando não existe projeto/processo de autoavaliação institucional previsto/implantado. \\
\hline & $\begin{array}{l}\text { 2- Quando o projeto/processo de autoavaliação institucional está previsto/implantado e } \\
\text { atende de maneira insuficiente às necessidades institucionais, como instrumento de gestão e } \\
\text { de ações acadêmicoadministrativas de melhoria institucional. }\end{array}$ \\
\hline & $\begin{array}{l}\text { 3- Quando o projeto/processo de autoavaliação institucional está previsto/implantado e } \\
\text { atende de maneira suficiente às necessidades institucionais, como instrumento de gestão e } \\
\text { de ações acadêmicoadministrativas de melhoria institucional. }\end{array}$ \\
\hline & $\begin{array}{l}\text { 4- Quando o projeto/processo de autoavaliação institucional está previsto/implantado e } \\
\text { atende muito bem às necessidades institucionais, como instrumento de gestão e de ações } \\
\text { acadêmicoadministrativas de melhoria institucional. }\end{array}$ \\
\hline & $\begin{array}{l}\text { 5- Quando o projeto/processo de autoavaliação institucional está previsto/implantado e } \\
\text { atende de maneira excelente às necessidades institucionais, como instrumento de gestão e de } \\
\text { ações acadêmicoadministrativas de melhoria institucional. }\end{array}$ \\
\hline \multirow{5}{*}{ 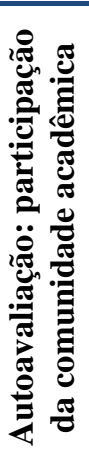 } & $\begin{array}{l}\text { 1- Quando não existe participação da comunidade acadêmica no processo de autoavaliação } \\
\text { previsto/implantado. }\end{array}$ \\
\hline & $\begin{array}{l}\text { 2- Quando o processo de autoavaliação está previsto/implantado, com participação } \\
\text { insuficiente da comunidade acadêmica. }\end{array}$ \\
\hline & $\begin{array}{l}\text { 3- Quando o processo de autoavaliação está previsto/implantado, com participação } \\
\text { suficiente da comunidade acadêmica. }\end{array}$ \\
\hline & $\begin{array}{l}\text { 4- Quando o processo de autoavaliação está previsto/implantado, com participação muito } \\
\text { boa da comunidade acadêmica. }\end{array}$ \\
\hline & $\begin{array}{l}\text { 5- Quando o processo de autoavaliação está previsto/implantado, com participação } \\
\text { excelente da comunidade acadêmica. }\end{array}$ \\
\hline \multirow{5}{*}{ 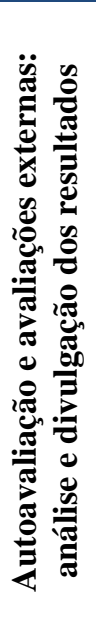 } & $\begin{array}{l}\text { 1- Quando não existe divulgação das análises dos resultados do processo de autoavaliação } \\
\text { institucional e das avaliações externas para a comunidade acadêmica. }\end{array}$ \\
\hline & $\begin{array}{l}\text { 2- Quando a divulgação das análises dos resultados do processo de autoavaliação } \\
\text { institucional e das avaliações externas previstas/implantadas ocorre, de maneira insuficiente, } \\
\text { para a comunidade acadêmica. }\end{array}$ \\
\hline & $\begin{array}{l}\text { 3- Quando a divulgação das análises dos resultados do processo de autoavaliação } \\
\text { institucional e das avaliações externas previstas/implantadas ocorre, de maneira suficiente, } \\
\text { para a comunidade acadêmica. }\end{array}$ \\
\hline & $\begin{array}{l}\text { 4- Quando a divulgação das análises dos resultados do processo de autoavaliação } \\
\text { institucional e das avaliações externas previstas/implantadas ocorre, de maneira muito boa, } \\
\text { para a comunidade acadêmica. }\end{array}$ \\
\hline & $\begin{array}{l}\text { 5- Quando a divulgação das análises dos resultados do processo de autoavaliação } \\
\text { institucional e das avaliações externas previstas/implantadas ocorre, de maneira excelente, } \\
\text { para a comunidade acadêmica. }\end{array}$ \\
\hline \multirow{5}{*}{ 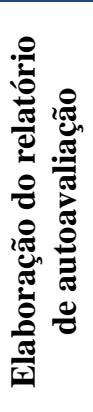 } & 1- Quando não existe relatório de autoavaliação. \\
\hline & $\begin{array}{l}\text { 2- Quando o relatório de autoavaliação é insuficiente, apresentando resultados sem análises, } \\
\text { reflexões e proposições para subsidiar planejamento e ações. }\end{array}$ \\
\hline & $\begin{array}{l}\text { 3- Quando o relatório de autoavaliação apresenta resultados, análises, reflexões e } \\
\text { proposições de forma suficiente para subsidiar planejamento e ações. }\end{array}$ \\
\hline & $\begin{array}{l}\text { 4- Quando o relatório de autoavaliação apresenta resultados, análises, reflexões e } \\
\text { proposições de forma muito boa para subsidiar planejamento e ações. }\end{array}$ \\
\hline & $\begin{array}{l}\text { 5- Quando o relatório de autoavaliação apresenta resultados, análises, reflexões e } \\
\text { proposições de forma excelente para subsidiar planejamento e ações. }\end{array}$ \\
\hline
\end{tabular}

Fonte: Brasil/Inep/Daes, 2014, p. 5-6. 
A partir do olhar externo de avaliadores sob o relatório de autoavaliação, espera-se dar às IES o feedback necessário nunca antes dado sobre sua autoavaliação. De acordo com Verhine (2013),

[...] ao adotar a avaliação externa da autoavaliação institucional, o Brasil segue uma prática que é comum em muitos países. No Reino Unido, por exemplo, a avaliação externa da educação superior, denominada "Auditoria", focaliza, quase exclusivamente, as estruturas e os mecanismos adotados pela instituição para assegurar sua qualidade. Os auditores julgam o nível de confiança que têm na gestão da qualidade da IES e na integridade das informações por ela publicadas. [...] A lógica do sistema britânico se fundamenta na premissa de que uma instituição que assegura bem sua própria qualidade é uma instituição que merece ser bem avaliada. (p. 54-55).

Conforme representante da Daes/Inep, entrevistado, "um avaliador in loco hoje o primeiro documento que ele vai analisar é o relatório de autoavaliação. Então ele vai conhecer a instituição a partir da forma que ela se declara, que é no relatório de autoavaliação.”. (IN, informação verbal). De acordo com entrevistado da Conaes, por sua vez, se antes o que se tinha na prática era uma autoavaliação com fim simplesmente de cumprimento burocrático, atualmente foi dado sentido a esse processo; e as próprias IES, sobretudo as de pequeno porte, enxergam na autoavaliação algo digno de valorização:

Os avaliadores de curso, o novo instrumento de avaliação institucional ele contempla o relatório de autoavaliação. Então, esse relatório de autoavaliação, em primeiro lugar, ele deixou de ser um documento puro e simplesmente burocrático. Agora hoje eu diria o seguinte: que politicamente, para a instituição, ele é importante. E, sobretudo, eu arriscaria dizer, para as instituições menores, que são a grande maioria de instituições no Brasil. Eu não tô falando de universidades federais públicas. Eu não tô falando de grandes grupos conglomerados educacionais. Eu estou falando das milhares de faculdades que existem no Brasil. Que hoje, e eu tive depoimento, e não foi de uma, de várias instituições que fala: "nós não podemos prescindir a avaliação institucional hoje". Às vezes, eu até provocando: "mas a gente podia dar um intervalo e ao invés de ser de dois em dois anos...." "Definitivamente não. Nós temos que fazer essas avaliações e nós não podemos deixar que elas não sejam anuais.". E por quê? "Porque no nosso conhecimento de todo o processo hoje é com base nisso.”. Então já tem um sentimento que mostra que tá mudando. ( $\mathrm{CO}$, informação verbal).

Essa mudança de perspectiva quanto à autoavaliação aconteceria "porque o instrumento de avaliação institucional ele dá uma ênfase diferenciada para a autoavaliação.”. (CO, informação verbal). E essa ênfase, por sua vez, devolveria, segundo o entrevistado da Conaes, o previsto destaque sonhado para esse processo avaliativo. Não suficiente, de acordo 
com agente da Daes/Inep, entrevistado, se passaria agora a se utilizar efetivamente "os resultados dentro da própria instituição.”. (IN, informação verbal).

Em suma, os representantes de algumas das instâncias máximas da avaliação da educação superior do país - Conaes e Inep - demonstram de maneira muito otimista que apesar de durante dez anos se ter contado com uma autoavaliação com finalidade burocrática (já que sem retorno e com resultados que não surtiam efeito), a partir de 2014, agregando a autoavaliação ao processo regulatório da avaliação institucional externa "tudo tá mudando.". (CO, informação verbal).

Repensada a questão dos eixos e do retorno dos relatórios, restava ainda, com base nas pesquisas aludidas neste item, (i) orientação sobre o que se entende como relatório parcial e final e ainda (ii) capacitação das CPA. Com a Nota Técnica nº 65, de 09 de outubro de 2014 (BRASIL/INEP/CONAES, 2014), por sua vez, tenta-se contornar essa primeira questão. Até o ano de 2014 não estava claro o que significava no contexto do Sinaes a ideia de ciclo avaliativo, assim, anualmente, as IES postavam no sistema e-MEC o que poderia ser ou um relatório final de autoavaliação ou um relatório parcial, vis-à-vis justamente a falta de informação sobre o prazo de um ciclo. Com essa Nota, no entanto, as IES passariam a partir de 2015 não só a trabalhar com a referência dos cinco eixos avaliativos, mas com um prazo mais justo e também levando em conta outras considerações (BRASIL/Inep/Conaes, 2014). O prazo estabelecido para postagem do primeiro relatório do ciclo foi até 31 de março de 2016, o segundo em mesma data no ano de 2017, e o final em 2018; ademais, em resumo, a Nota indicou que:

- O processo de autoavaliação deve aproveitar os resultados das avaliações externas e as informações coletadas e organizadas a partir do PDI;

- O relatório de autoavaliação deve fomentar a cultura de avaliação e subsidiar os processos de avaliação externa;

- O relatório de autoavaliação deve conter cinco partes: introdução, metodologia, desenvolvimento, análise dos dados e das informações, e ações previstas com base nessa análise;

- A autoavaliação deverá ser desenvolvida em uma periodicidade de três anos, sendo que nos dois primeiros anos deverá ser postado no sistema e-MEC um relatório parcial e no último um integral;

- O relatório parcial deverá contemplar as informações e ações desenvolvidas pela CPA no ano de referência anterior, explicitando os eixos trabalhados; E, por fim, 
- O relatório integral deverá contemplar as informações e ações desenvolvidas pela CPA no ano de referência, bem como retomar o conteúdo dos relatórios parciais, explicitando uma análise global em relação ao PDI e a todos os eixos, e ainda um plano de ações de melhoria às IES.

Com todos esses esclarecimentos sobre as medidas recentes sob a autoavaliação, tem-se que (i) o processo de autoavaliação passa a ter, obrigatoriamente, que basear-se no PDI e nos resultados da avaliação externa; (ii) o processo de avaliação externa deve valer-se obrigatoriamente dos relatórios de autoavaliação; (iii) um ciclo avaliativo deverá durar 3 anos, sendo essa a periodicidade para postagem dos relatórios parciais e final, tendo cada tipo uma prerrogativa própria; e, com tudo isso, (iv) a autoavaliação deveria fomentar uma cultura de avaliação formativa na IES. Assim, além de se direcionar o contorno de problemas, como a elaboração de relatórios completos, retorno sobre os relatórios enviados e delimitação do que seja parcial e final, essa nota e a portaria anteriormente aludida, retomam a questão da cultura de avaliação formativa e dão mais extensão à autoavaliação.

Outro problema a ser contornado, por sua vez, seria a questão da capacitação das CPA. Como visto no item anterior, a Conaes teve papel de destaque quando do início da política do Sinaes ao esclarecer às CPA o que era a autoavaliação. Agora, as instituições já estão acostumadas com o processo, mas é sempre urgente a capacitação constante das CPA. Segundo entrevistado representante da Daes/Inep, em prol disso, o Instituto faz-se presente em eventos relacionados à autoavaliação, assim como desde 2013 vem promovendo seminários com as CPA. Nesses seminários, de acordo com o mesmo, a "ideia é que eles se reúnam como $\mathrm{CPA}$, reconheçam essa instancia organizada dentro da instituição, pra que a experiência de uma instituição também sirva de experiência pra outra.”. (IN, informação verbal). Sendo assim, a capacitação se daria na relação entre os pares; na troca de experiências. Segundo representante da Conaes,

Só para você ter uma ideia, há dois anos atrás por uma iniciativa louvável do Inep, [...], e que a Conaes acompanhou de perto todo esse processo, houveram algumas reuniões regionais das CPA em 5 regiões do Brasil. E foi uma iniciativa muito enriquecedora. Porque discutiu-se, socializou-se o conhecimento e houve possibilidade das CPA daquelas regiões se integrarem sobre dimensões diferentes, faculdade, centro universitário, universidade, com dependências administrativas distintas.... Enfim, foi um processo muito enriquecedor. (CO, informação verbal).

Resta saber se as reconfigurações na autoavaliação empreendidas tão tardiamente, a partir de 2014 - por advento da Portaria n 92, de 31 de janeiro de 2014 (BRASIL/MEC, 
2014) e da Nota Técnica do Inep/Conaes $n^{\circ}$ 065, de 09 de outubro de 2014 (BRASIL/INEP/CONAES, 2014) -, ou a partir dos recentes seminários realizados são capazes de trazer benefícios o suficiente para contornar a preocupação excessiva com a consequência dos resultados obtidos com base no Enade.

A criação dos índices baseados no Enade trouxe infinitos dados para subsidiar processos regulatórios. No entanto, a subsunção, em parte, da Avaliação de Cursos por esse e o fato de só em 2014 se ter olhado para a avaliação institucional e especificamente para a autoavaliação de forma mais substancial fez com que o processo de implementação do Sinaes tenha sido marcado por contradições em relação a sua proposta original.

Identificam-se no contexto do Sinaes três momentos determinantes: (i) uma proposta formativa, apresentada em 2004 por advento da Lei n 10.861/2004 (BRASIL, 2003); (ii) um retorno a práticas controladoras, com a supervalorização do Enade a partir da criação do Decreto $n^{\circ}$ 5.773/2006 (BRASIL, 2006), que desencadeou a criação dos índices em 2008; e um momento atual - híbrido - em que mantem-se índices, mas passa-se a valorizar mais a autoavaliação a partir do Parecer e da Nota técnica de 2014. Como aponta Gonçalves (2015), ao se levar em consideração somente a proposta do Sinaes, muito pautada nos preceitos da CEA,

[...] uno creía que fuera formativa, ya que se proponía dar centralidad a la evaluación institucional, procedimiento donde la institución de educación superior sería la protagonista y la mayor beneficiada. Sin embargo, especialmente a partir de 2006 el sistema se modifica, quitándole la centralidad de la evaluación institucional y atribuyendo a la evaluación del alumno - el Enade - el más sobresaliente. ${ }^{62}$. (p. 298-299).

Há, desse modo, um retorno a práticas controladoras; não nos mesmos contornos das políticas avaliativas anteriores, como o ENC, mas bastante sobressalente. A luz de Krapívine (1986), que defende em políticas públicas a existência de uma "lei da negação da negação", no entanto, se entende que, para que a política de avaliação da educação superior brasileira se desenvolvesse, esse retorno ao aspecto controlador estava previsto. O momento de criação do Sinaes, o qual seria denominado pelo autor como momento de negação dialética, seria marcado pela ruptura proporcionada pelo Sinaes como resposta ao ENC e demais avaliações. Contudo, o momento de ruptura, para o mesmo, não tem fim em si mesmo, representando

\footnotetext{
${ }^{62}$ [...] as pessoas acreditavam que fora formativa, já que se propunha a dar centralidade à avaliação institucional, procedimento em que a instituição de educação superior seria a protagonista e a maior beneficiada. Contudo, especialmente a partir de 2006 o sistema se modifica, tirando a centralidade da avaliação institucional e passando à avaliação do estudante - o Enade - o que mais se destacava. (Tradução nossa).
} 
para a dialética apenas uma etapa do processo de negação. Esse processo pressupõe o resgate de algumas das práticas cujo novo pretendeu, a princípio, negar, do que se explica o Sinaes, especialmente a partir de 2008, destoar-se tanto de sua proposta original. É que o processo de negação, conforme Krapívine (1986, p. 177), “não se dá de forma absolutamente pura. É certo que o novo assimila o que há de positivo no velho; contudo, alguns vestígios negativos velhos podem macular o elemento novo".

Para se instaurar uma política avaliativa de Estado verdadeiramente formativa, negando, portanto, o controle, parece natural que se retorne a esse último como quem experimenta algo com o fim de checar se realmente não gosta. É preciso, contudo, mais tempo para perceber que rumos as novas determinações sob a avaliação institucional e a manutenção dos índices darão ao Sinaes e à autoavaliação, em específico. A partir das últimas resoluções do Parecer e da Nota Técnica de 2014, a autoavaliação parece estar sendo mais bem amparada e valorizada; e a avaliação formativa volta a sobressair-se. Contudo, é precipitada uma definição sobre o caráter atual do sistema avaliativo; esse passa por um momento híbrido. Conforme a própria Coordenadora Geral de Qualidade da Educação Superior, em entrevista em 2015, contudo, a Lei do Sinaes,

[...] embora fundamentada em uma concepção de avaliação formativa e emancipatória, oriunda do ideário e experiência de algumas pessoas, não era a prioridade do Estado, que tinha urgência no regramento e em dados concretos para fazer a regulação. Nesse contexto, a frase: "A avaliação dá subsídios para regulação" foi e é interpretada conforme a lente e o interesse de quem a lê. Assim, em alguns casos entende-se que a avaliação não está subordinada à regulação, tendo processos e demandas próprios; em outros, porém, entende-se que a avaliação só existe para subsidiar a regulação. [...] Por conta disso, na minha percepção - próxima de muitos autores atuais -, a política de regulação acabou "tomando o espaço" da política de avaliação. Pois os processos avaliativos do Sinaes - o tripé -, embora de fato sejam contributivos para a melhoria da qualidade do sistema (e não tenho dúvidas de que contribuem de verdade), vêm sendo realizados ainda de forma: (i) pouco orgânica e integrada; (ii) sob o comando e conforme o interesse da regulação. (MENEGHEL, 2015, p. 195).

O processo de implementação do Sinaes, como sugere a fala destacada e todo este subitem do capítulo, corroborou uma política avaliativa que se encontra, de certa forma, subordinada à regulação e subsumindo a autoavaliação institucional. O Sinaes não tem, em sua essência, caráter controlador, mas para continuar não tendo é preciso equilibrar, imediatamente, regulação e avaliação formativa. As medidas, ainda que tardias, para alavancar a autoavaliação é um importante passo para tal. No entanto, ainda faz-se preciso 
levar em conta a maneira como a proposta da autoavaliação está sendo ressignificada pelos agentes envolvidos, inclusive visualizando como essas modificações vêm sendo encaradas. A isso, se dará continuidade no capítulo seguinte.

\subsection{SÍNTESE PARCIAL}

A discussão desenvolvida neste segundo capítulo, sobre as idas e vindas de avaliações de cunho formativo ou controlador, evidenciou que toda política avaliativa recebe influências tanto da conjuntura histórica e política em que é concretizada, como dos modelos avaliativos anteriores.

No Brasil, antes do Sinaes houve quatro políticas, ou projetos de políticas públicas, de avaliação da educação superior em nível de graduação, quais sejam: o Programa de Avaliação da Reforma Universitária (Paru), de 1983; o Grupo Executivo para a Reformulação do Ensino Superior (Geres), de 1986; o Programa de Avaliação Institucional das Universidades Brasileiras (Paiub), de 1993; e o Exame Nacional de Cursos (ENC), de 1996. Esses, sob contextos políticos específicos, mas sob o mesmo Estado capitalista de inclinação neoliberal, se constituíram, como visto, em avaliações ora essencialmente formativas, ora essencialmente controladoras - em uma espécie de revezamento de tipos avaliativos.

O Sinaes, por sua vez, como síntese de um novo contexto histórico e político, mas também dessas políticas avaliativas que o antecederam, surgiu como política de Estado e não de governo, vindo, portanto, para durar e constantemente se aprimorar. Seu aprimoramento, no entanto, não tomou como exemplo somente as políticas avaliativas de cunho formativo, mas também as de cunho controlador. Assim, se na proposta do Sinaes identificou-se a essência do Paiub - avaliação formativa -, atualmente observa-se que o sistema incorporou novos elementos e retornou, em parte, ao controle, tão presente, por exemplo, no ENC.

A influência de avaliações superadas, contudo, não é direta e simplista, senão sutil. Qualquer equivalência entre um pilar do Sinaes e uma avaliação precedente é uma subversão ao trabalho da CEA, que com tanto pessoal qualificado e sob várias reuniões e discussões projetou o sistema. Esse, ainda que falho, carrega não só contradições, mas toda a esperança de mudanças substanciais na política de avaliação da educação superior brasileira; e vem trazendo medidas recentes que a médio e longo prazo podem equalizar regulação e avaliação formativa. 
É preciso ter em mende que as ações empreendidas pelo Estado capitalista não se implementam automaticamente; elas têm movimento, têm contradições e podem gerar resultados realmente diferentes dos esperados. (HOFLING, 2001). Na proposta do Sinaes encontra-se um sistema avaliativo que dialoga seus três eixos, que respeita a identidade institucional e as particularidades de cada sistema, que dá centralidade à avaliação institucional e em especial à autoavaliação, dando mais autonomia às IES, e que promove atos regulatórios baseados na articulação de vários eixos ou de vários componentes. Na prática de implementação da política muito disso, como visto, se perdeu, o que, no entanto, não faz com que o Sinaes se converta em um caso perdido.

Em especial a partir do segundo mandato do governo Lula (2007-2010), ficou mais nítido o destaque dado à regulação em virtude do Decreto Ponte e da posterior criação de índices a partir dos resultados do Enade. $\mathrm{O}$ ato de regular não é ruim e nem prejudicial ao sistema educacional, mas investir nisso sem investir igualmente em avaliação formativa e na subsequente formação e consolidação de uma cultura avaliativa formativa nas IES o é. A cada docente que se veja impelido a ensinar para a prova do Enade; ou a cada relatório de autoavaliação que ao invés de ser usado em prol de avanços na IES seja, por exemplo, engavetado, se sentirá o efeito prejudicial da falta de equilíbrio entre os pilares do Sinaes e entre regulação e avaliação formativa.

Medidas como a Portaria $n^{\circ} 92 / 2014$ (BRASIL/MEC, 2014) e a Nota Técnica $n^{\circ}$ 065/2014 (BRASIL/INEP/CONAES, 2014), ao voltarem o olhar à avaliação institucional e especificamente à autoavaliação, devolveram a esperança de ruptura com a política educativa de corte neoliberal, à qual já se está acostumado no Brasil. Ao que parece, a regulação ainda não passou a esgotar-se em si mesma e, finalmente, um olhar diferenciado tem sido dado à avaliação formativa.

O Sinaes encontra-se, de fato, em um momento híbrido; em que se faz difícil assegurar seu rumo. No capítulo que segue, no entanto, se perscrutarão as vozes de envolvidos direta ou indiretamente com a autoavaliação institucional e se caminhará mais rumo à compreensão das ressignificações feitas para essa avaliação. Na autoavaliação, o simbolismo da inovação é depositado. Para que isso passe do simbólico ao real, é preciso observar a prática e usá-la a favor de se continuar aprimorando o sistema avaliativo com vistas a atitudes não controladoras. 


\section{CAPÍTULO 3: AUTOAVALIAÇÃo NA UNIVERSIDADE DE BRASÍLIA: ENTRAVES E POSSÍVEIS AVANÇOS}

\subsection{INTRODUÇÃO}

O período em que esta pesquisa foi desenvolvida não poderia ter sido um momento mais propício. O Sinaes, a partir de 2008 , inaugura uma fase de aparente rompimento com a totalidade do sistema ao valorizar mais o Enade e os índices que a partir de então passaram a serem gerados com base nele. Todavia, em 2014 - primeiro ano de desenvolvimento deste estudo -, dá-se início a outro momento dessa política pública avaliativa. Com a publicação da Portaria $\mathrm{n}^{\circ}$ 92/2014 (BRASIL/MEC, 2014) e da Nota Técnica $\mathrm{n}^{\circ}$ 065/2014 (BRASIL/INEP/CONAES, 2014), inaugura-se uma fase de implementação de medidas para alavancar a avaliação institucional e valorizar a autoavaliação - objeto desta pesquisa.

O legado deixado por uma configuração de Estado que sempre priorizou o controle sob a educação superior não é, contudo, algo fácil nem rápido de se superar. No que tange à política de avaliação desse nível educacional, no país, é preciso pensar que "o que uma geração construiu e deixou como legado às próximas gerações não pode ser descartado como num passe de mágica, como nos parece quererem: os anarquistas, quando propõem o fim do Estado burguês e a negação de qualquer outro Estado". (FÉLIX, 2013, p. 120). Consequentemente, mesmo que se esteja tentando valorizar agora também a autoavaliação, e não só o Enade, é preciso tempo para que a ruptura definitiva às práticas controladoras seja consolida.

Ainda que se vivenciem implementações aparentemente favoráveis, seria prematuro afirmar que, a partir das mudanças da avaliação institucional empreendidas em 2014, o Sinaes se definiria, definitivamente, como uma avaliação formativa não só no texto da Lei, mas na prática, colocando a autoavaliação finalmente como eixo central do processo. Qualquer avanço nesse sentido depende de como os sujeitos envolvidos reagem à autoavaliação, já que muito "da potência da proposta inicial de avaliação pode ser recomposta se os atores sociais se organizarem e lutarem para produzir novos sentidos esquivando-se da cultura de resultados orientados pelo gosto do mercado.". (GARCIA; ESPINDOLA; SORDI, 2011, p. 32).

Por mais de uma década houve no Brasil a prevalência de políticas avaliativas controladoras - Geres e ENC -, além da subsunção de políticas avaliativas de viés formativo 
- Paru e Paiub - (OLIVEIRA et. al., 2013; POLIDORI, et. al., 2011; QUEIROZ, 201; ROTHEN; BARREYRO, 2008). O Paru, como mostrado no capítulo 2, permaneceu somente como proposta avaliativa; e o Paiub não contou com total apoio do governo, sendo tacitamente deixado de lado quando da criação do ENC. O Sinaes, por sua vez, não se enquadra ainda em nenhum desses grupos (formativo ou controlador) na visão da autora desta dissertação. O sistema avaliativo em vigência, a partir do momento em que foi instituído como política de Estado e não de governo e que trouxe uma proposta formativa, na qual a regulação e avaliação formativa teriam suas forças equalizadas, deu início a um primeiro estágio de mudança para a política avaliativa do país: a ruptura. Esse estágio, no entanto, assim como acontece em todas as políticas públicas (KRAPÍVINE, 1986), pressupõe um processo. Consequentemente, tudo o que se tem vivenciado de implementação dessa política avaliativa pode representar, ainda, um momento de transição, o qual levará à sobreposição das práticas formativas sob as controladoras, no que tange às avaliativas da educação superior. Tudo isso dependerá, no entanto, de como os agentes envolvidos com a avaliação reagem à autoavaliação.

A necessidade da regulação gerou os índices e, como a regulação, por si só, não é um problema, esses não precisam ser retirados do Sinaes. Refletindo sobre tudo o que foi escrito até aqui, percebe-se que a grande problemática, em verdade, é a prevalência da regulação sob a avaliação formativa e a decorrente subsunção dessa última, já que isso é o que faz o controle sobressair. Caso, no entanto, a valorização do processo avaliativo mais formativo do Sinaes a autoavaliação -, reafirmado pelas medidas legais tomadas em 2014, vigore de fato, as práticas de regulação e de avaliação estarão mais equalizadas, se alcançando o equilíbrio idealizado por Dias Sobrinho (2010), aludido no capítulo 1. Assim, se poderá alcançar e fomentar, mais facilmente, a tão almejada qualidade educacional.

Nesse sentido, é preciso adentrar mais à prática avaliativa, compreendendo a ressignificação que a universidade corpus desta pesquisa - UnB - faz da autoavaliação. Como visto no referido capítulo, um dos níveis de regulação existentes é o da microrregulação local, o qual consiste, no caso da investigação regulação, no modo como cada IES recebe e reajusta as deliberações do Estado em seu contexto local. (BARROSO, 2006). A lei 10.861/2004 (BRASIL, 2004a) deliberou a obrigatoriedade da realização da autoavaliação, formação da CPA para tal etc. A Portaria $n^{\circ}$ 92/2014, organizou as 10 dimensões da avaliação institucional em cinco eixos que deveriam necessariamente ser atendidos no processo de autoavaliação. (BRASIL/MEC, 2014). A Nota Técnica $n^{\circ}$ 65, de 09 de outubro de 2014 (BRASIL/INEP/CONAES, 2014), entre outras questões, esclareceu a ideia de ciclo avaliativo 
e, a partir dela, seria no período de três anos que se avaliariam os cinco eixos da IES (BRASIL/Inep/Conaes, 2014). Como, no entanto, a UnB se regula a fim de atender essas medidas?

Considerando o exposto, o presente capítulo tem por objetivo analisar e interpretar os dados coletados nas entrevistas semiestruturadas realizadas com sujeitos que lidam com esse processo avaliativo - membros da CPA da UnB; representantes da Daes/Inep e da Conaes; e pesquisadores da área -, bem como nos documentos oficiais pertinentes, perscrutando a autoavaliação na prática. Para tal, conta-se com o aporte teórico da análise de conteúdo baseada em Bardin (2004) e com a teoria que já vem auxiliando a pesquisadora nos capítulos anteriores.

Vale lembrar que uma análise, conforme Lefebvre (1979), deve sempre captar a relação complexa e contraditória do objeto em questão, o qual tem seus elementos igualmente complexos e conflitantes entre si e com a totalidade. Para o autor, o pensamento dialético, mostra que todo objeto a ser analisado possui momentos reais passíveis de serem desvendados. A análise, então, "deve apreender e determinar, através de seus "momentos" cada ser em sua originalidade, cada ação naquilo que a diferencia de todas as outras" (p. 119), o que se esforçou para se fazer neste capítulo.

Dez interlocutores foram auscultados, sendo um representante da Daes/Inep, um da Conaes, quatro pesquisadores da área de avaliação da educação superior e quatro membros da CPA da UnB - um de cada segmento representativo. Esses revelam um olhar macro e micro sob o objeto desta pesquisa, o que é muito importante no tratamento da autoavaliação entre suas múltiplas determinações. A síntese desses olhares, por sua vez, não compõe uma prerrogativa do futuro do Sinaes - se voltado ao controle ou à avaliação formativa -, mas um recorte do processo de implementação do que seria o pilar desse: a autoavaliação institucional. É por meio de sua práxis que os sujeitos da pesquisa interpretam dialeticamente a realidade; e para Marx e Engels (1996) a práxis tem primazia em relação à teoria. "A questão de saber se ao pensamento humano pertence à verdade objetiva não é uma questão teórica, mas uma questão prática. É na práxis que o ser humano tem de comprovar a verdade, isto é, a realidade e o poder, o caráter terreno do seu pensamento”. (p. 107-108).

Assim, por meio do estudo empírico embasado na teoria abordada nos capítulos anteriores e naquela retomada no presente capítulo, buscou-se dar continuidade à compreensão de em que medida o previsto pela política do Sinaes para a autoavaliação é ressignificado na prática da Universidade de Brasília. O Sinaes prevê que a autoavaliação se dê em três momentos, conforme já dito na introdução e no capítulo 2 deste trabalho: (i) a 
preparação; (ii) o desenvolvimento; e (iii) a consolidação. Mas todos esses momentos, sob um contexto não favorável, encerram muitas contradições envolvendo o planejado e o praticado, sendo, consequentemente, reconfigurados no dia a dia institucional. No decorrer deste capítulo, que conta com três seções, se verá isso.

Primeiramente, no item 3.1 discorre-se sobre as perspectivas de análise e interpretação dos dados, lembrando que sobre isso já se comentou um pouco nas considerações iniciais da pesquisa. Em seguida, no item 3.2, problematiza-se a fase da preparação da autoavaliação, o que passa pela sensibilização da comunidade acadêmica e da própria CPA. No 3.3, discutemse as fases de desenvolvimento e consolidação da autoavaliação a partir da problematização da elaboração dos relatórios e do uso desses pela gestão da IES. Finalmente, chega-se às conclusões parciais alcançadas no percurso do capítulo. Por esse caminho, tanto se ajuda a compreender o momento de transição em vigência, como a cumprir com os objetivos a que este trabalho se comprometeu logo em sua primeira parte. A questão do significado atribuído à autoavaliação, da conformidade dos relatórios ao que a política do Sinaes espera e da repercussão dos resultados apontados nos relatórios ganham grande amplitude.

\subsection{PERSPECTIVAS DE ANÁLISE E INTERPRETAÇÃO DOS DADOS}

Como mostra Félix (2013), "antes do triunfo do novo, haverá longos períodos de transição até que o novo se mostre superior" (p.58); e é exatamente o que se tem percebido neste trabalho quando se reflete sobre o lugar da autoavaliação e, portanto, da avaliação formativa, nas políticas de educação superior do Brasil. O movimento histórico de implementação da autoavaliação institucional é repleto de momentos de destaque e de subsunção dessa, os quais expõem as contradições de um Estado que muitas vezes promete algo, mas não cumpre. Diante disso, a compreensão da realidade da autoavaliação pressupõe que também na análise e interpretação dos dados extraídos dos documentos oficiais e das entrevistas realizadas se dê continuidade à problematização das mediações e contradições que perpassam a historicidade desse momento avaliativo.

Em consonância às discussões teóricas realizadas no decorrer deste trabalho a respeito: (i) da questão da qualidade em educação superior; (ii) do movimento histórico das políticas públicas de avaliação; (iii) e da autoavaliação na implementação do Sinaes, sentiu-se a necessidade de analisar documentos oficiais em fontes de dois níveis diferentes: central 
(Brasil) e local (IES). No nível central deu-se especial atenção aos documentos mais recentes que interferem na autoavaliação: a Portaria n ${ }^{\circ}$ 92/2014 e a Nota Técnica $n^{\circ}$ 065/2014, sobre as quais se teceram algumas considerações no capítulo anterior. Contudo, ainda neste nível de compreensão, também sentiu-se a necessidade de ponderar algumas questões na $\mathrm{CF}$, na LDBEN e nos PNE - o que foi contemplado no capítulo 1 - e outras nas atas das reuniões ordinárias da Conaes - sobre o que se discute no próximo item deste capítulo. Já no nível local, a atenção voltou-se ao Plano de Desenvolvimento Institucional (PDI) e aos dois últimos relatórios de autoavaliação institucional da UnB, referentes aos anos de 2014 e 2015, os quais perpassam os dois tópicos seguintes.

As entrevistas semiestruturadas, por sua vez, foram feitas com os agentes já citados, tendo servido seus roteiros como pontos de referência, os quais encontram-se anexos ao trabalho $^{63}$. Neles se observa três blocos de perguntas. O primeiro bloco refere-se aos relatórios de autoavaliação e o atendimento às dimensões da política do Sinaes. O segundo ao uso dos resultados da autoavaliação pela gestão da universidade. E o terceiro ao significado atribuído à autoavaliação no contexto atual. Não suficiente, a partir da abertura dada pelo interlocutor no momento da entrevista foram levantadas questões referentes à trajetória acadêmica e profissional de cada um, assim como questões complementares relacionadas especificamente ao objeto da pesquisa.

Em conformidade ao olhar dialético que se quis imprimir ao presente trabalho, bem como à abordagem qualitativa nele adotada - sobre o que já se falou nas considerações iniciais da pesquisa -, as entrevistas e também os documentos em nível central e local foram analisados, descritivamente, por meio da Análise de Conteúdo Temático, proposta por Bardin (2004). Essa se constitui de varias técnicas que buscam descrever o conteúdo emitido no processo de comunicação falada ou escrita, perscrutando as percepções que determinado sujeito ou entidade representativa têm sobre um objeto, nesse caso, a autoavaliação institucional.

Segundo Bardin (2004), o objetivo da análise de conteúdo é "a manipulação de mensagens (conteúdo e expressão desse conteúdo), para evidenciar os indicadores que permitam inferir sobre uma [sic] outra realidade que não a da mensagem.”. (p. 51). E a evidenciação desses indicadores se dá a partir de um roteiro específico de três etapas, as quais foram seguidas nesta pesquisa. A primeira etapa é a pré-análise, que a qual se refere à escolha

\footnotetext{
${ }^{63}$ Observa-se que no fim de uma das entrevistas realizadas no decorrer da pesquisa, o entrevistado elogiou o roteiro de perguntas: "Eu achei que está bem completo o instrumento, você consegue abordar absolutamente tudo com as suas perguntas." (TE, informação verbal).
} 
de documentos ou, no caso em questão, também na dos sujeitos entrevistados, formulação de hipóteses e determinação de objetivos - ações realizadas até o momento de qualificação desta pesquisa. A segunda é a exploração do material propriamente dito - os documentos em si e as transcrições das entrevistas, enquanto a terceira é a etapa dos resultados e interpretações.

A pré-análise possui subfases, quais sejam: (i) leitura flutuante, momento no qual a autora deste trabalho leu tudo o que ela encontrou sobre o objeto da pesquisa; (ii) escolha dos documentos e dos grupos de entrevistados, que nada mais foi do que um filtro que a mesma fez a partir da exaustividade, representatividade, homogeneidade e pertinência; (iii) formulação de hipóteses e objetivos, os quais foram declarados nas considerações iniciais deste trabalho; (iv) referenciação dos índices e elaboração de indicadores, o que aqui se constituiu na elaboração dos relatórios das entrevistas; e, finalmente, (v) preparação do material para análise, o que pressupôs organização e nitidez.

A exploração dos documentos oficiais e do material das entrevistas, por sua vez, se deu por classificação de categorias e temas captados do conteúdo, do que seguiu a respectiva enumeração da frequência em que esses apareciam. Essa fase foi basicamente uma decomposição dos textos em unidades menores, o que possibilitou tanto apreciar as questões que mais apareciam sobre a autoavaliação, como criar relações entre as falas dos entrevistados e desses com os documentos, por exemplo.

Finalmente, a fase do tratamento dos resultados obtidos e interpretação seria o momento em que se conectam os dados empíricos ao escopo teórico, permitindo avançar para as conclusões. Essa é a fase que se materializou no texto dos próximos dois itens deste capítulo, pois neles as falas dos entrevistados do nível macro (Inep, Conaes e pesquisadores) e do nível micro (CPA da UnB) são relacionadas entre si e ainda aos documentos oficiais, à revisão bibliográfica realizada sobre autoavaliação e a temas correlatos.

Seguindo esse roteiro, a análise e interpretação dos dados coletados foram conduzidas ao longo da pesquisa numa perspectiva qualitativa, tomando a proposta de Bardin (2004) como procedimento básico, visando alcançar os objetivos da pesquisa. Na sequência passa-se, primeiramente, à problematização da preparação da autoavaliação; em seguida, discute-se o desenvolvimento e consolidação da autoavaliação, tendo como foco os relatórios de autoavaliação e o respectivo uso desses nas tomadas de decisão da gestão da IES na visão da CPA da instituição pesquisada. 


\subsection{AUTOAVALIAÇÃO DESCONHECIDA: AS DIFICULDADES DE SE PREPARAR UMA CPA E UMA COMUNIDADE ACADÊMICA PARA ESSE PROCESSO AVALIATIVO}

Como visto no capítulo anterior, a avaliação institucional e especificamente a autoavaliação deveria ser o elemento principal do Sistema Nacional de Avaliação da Educação Superior. Em novembro de 2006, com pouco mais de dois anos de instituição do Sinaes, no entanto, Dias; Origuela e Marchelli (2006), já anunciavam que apesar de se estar tentando

[..] mudar a natureza regulatória que caracteriza o processo avaliativo no Brasil, introduzindo-se procedimentos que visam ao caráter formativo, [...] métodos apropriados para isso ainda não foram encontrados nem a cultura da auto-avaliação, que se faz necessária para tanto, está constituída. (p. 462).

Desse modo, ainda que a política do Sinaes, conforme visto no capítulo anterior, tenha empreendido ao inaugurar em caráter obrigatório a autoavaliação - algo com cujas IES não estavam familiarizadas - implementá-la como o planejado não seria fácil. A cultura autoavaliativa, ainda não existente a priori, deveria ser criada concomitantemente ao desenvolvimento do sistema. Entretanto, como bem pontuam Bandeira Adriola e Souza (2010, p. 55), a aculturação “de novos hábitos não se dá de forma automática nem imediata: a construção de uma cultura de avaliação é um processo que demanda tempo, continuidade, informação e reflexão capaz de provocar consciência institucional e novas atitudes mentais.”.

Diante, portanto, das dificuldades previsíveis, o esperado era que, a começar pela iniciativa de instâncias responsáveis pela coordenação, supervisão e execução do Sinaes, tivesse havido, desde o início, um significativo movimento para garantir que a autoavaliação conquistasse seu espaço no país. No entanto, como diz a metáfora aludida por Meneghel (2015, p. 196), “consertar o carro com a roda andando é muito difícil...”; tão difícil que, como visto no decorrer desta dissertação, práticas com essência regulatória foram sempre mais valorizadas do que as formativas, não tendo sido diferente no contexto do Sinaes.

Apesar da importante e constante presença de representantes do Inep e da Conaes em seminários que discutem avaliação formativa - como frisou o entrevistado desse primeiro órgão e como se identifica nas atas de reuniões desse último -, bem como o fato de, desde 2013, esse primeiro promover seminários regionais com representantes de CPA de todo o país, é preciso ter em mente que datam de 2014 ações mais abrangentes sob a autoavaliação. 
Como lembram Silva; Martins e Abdalla (2014), o Enade foi constantemente aprimorado, sendo sob seu escopo inaugurado uma série de índices, o que acabou por supervalorizar os resultados do exame em detrimento dos dois outros pilares avaliativos: avaliação de cursos e avaliação institucional. A autoavaliação, ao contrário, ficou um bom tempo sem ser assistida.

Ribeiro (2010) discutiu o processo de efetivação da autoavaliação em uma instituição pública e em outra de natureza privada de Minas Gerais. Participaram da pesquisa na IES privada dois dirigentes, 56 docentes e 318 discentes e na pública quatro dirigentes, 10 docentes e 35 discentes. Em ambas as IES, o estudo constatou que o processo autoavaliativo passou por três fases até o ano de 2009: (i) a do ano de 2004, que caracterizou a construção coletiva da proposta de autoavaliação; (ii) a de 2005 a 2006, em que houve uma "euforia" institucional exacerbada e forte participação da CPA nas IES; (iii) e, finalmente, a do final de 2008 e decorrer de 2009, em que o processo de autoavaliação perdeu destaque internamente, influenciado pelas novas orientações do MEC para a avaliação da educação superior - onde lê-se a valorização de índices e a não valorização da autoavaliação.

Dessa forma, não é por acaso que, inclusive em tom de desabafo, um dos pesquisadores da área de avaliação entrevistado afirma: "O corpo docente, eu fico assustada, os colegas não saberem do que se trata. "Sinaes?" "Autoavaliação?"; "Que que é isso?" "Preenchimento de questionários e de formulários que a Comissão envia que é tão inconveniente que eu faço para cumprir uma tabela."” (P4, informação verbal). De fato, não se conhece aquilo que historicamente não é assistido, não tem lugar e nem valor. $\mathrm{Na} 72^{\mathrm{a}}$ reunião ordinária da Conaes, em janeiro de 2011, o então membro notório saber Robert Evan Verhine

[...] afirmou crer que a maior crítica que tem no Sinaes, em termos de autoavaliação, é o fato de que, realmente, a autoavaliação não tem sido valorizada de acordo com a proposta inicial do Sinaes. Ponderou que tal proposta foi de certa forma meio idealista, propondo algo talvez impossível de acontecer, como, de fato, não aconteceu. Poucas instituições, realmente, conseguiram realizar sua autoavaliação. Mas a ideia original seria focalizar tudo a partir da autoavaliação. Se fosse resgatado esse sentido de autoavaliação, a preocupação com os indicadores estabelecidos externamente (CPC, IGC, etc.) não seria tão grande assim e a preocupação seria com os indicadores que a instituição teria desenvolvido em seu próprio processo interno, em uma dinâmica que elas conseguissem criar. (CONAES, 2011a).

Resgatando-se, então, o protagonismo da autoavaliação, a preocupação com os resultados do Enade não seria tão pungente e as duas frentes para as quais o Sinaes se presta - 
avaliação formativa e regulação - funcionariam de forma equilibrada. Mas por que parece que apesar de se ter essa consciência da necessidade de se olhar para a autoavaliação, pouco ou nada é feito em prol disso? Analisando, por exemplo, as atas das reuniões da Conaes, percebese que o que mais é discutido pelos membros é, por exemplo, questões referentes ao Enade e aos índices provenientes deste e não à autoavaliação institucional. A Comissão, que se reúne em média uma vez ao mês, disponibiliza em rede desde 2011 as atas de suas reuniões ordinárias mensais. Com a finalidade de se visualizar minimamente o que ela discute sobre a autoavaliação, todas as atas disponíveis até o ano de 2015 foram lidas e analisadas, para fins desta pesquisa, com base em Bardin (2004). Apreciou-se desde a da $72^{a}$ reunião ordinária - de janeiro de 2011 -, até a da $122^{\mathrm{a}}$, de novembro de 2015 - última desse ano.

Para o presente estudo, com exceção da autoavaliação, nenhuma categoria foi determinada a priori. No entanto, ao fim da leitura exaustiva das atas, identificaram-se sete temáticas que sintetizam o que foi recorrentemente discutido nas reuniões da Comissão ao longo desses cinco anos; e a questão da autoavaliação não foi, em termos de frequência, a primeira temática dessa lista. Na tabela a seguir encontram-se as categorias em ordem crescente de frequência em que aparecem nas atas analisadas.

Tabela 4: Frequência das categorias identificadas nas atas de janeiro de 2011 a novembro a novembro de 2015 das reuniões ordinárias da Conaes

\begin{tabular}{l|c}
\hline \multicolumn{1}{c|}{ Categoria } & Frequência \\
\hline Acreditação no Sistema Arcusul & 24 \\
\hline Exame Nacional de Desempenho de Estudantes - Enade & 17 \\
\hline Avaliação da Educação a Distância - EaD & 15 \\
\hline Adesão dos Sistemas Estaduais ao Sinaes & 13 \\
\hline Autoavaliação & 13 \\
\hline $\begin{array}{l}\text { Criação do Instituto Nacional de Supervisão e Avaliação da Educação Superior } \\
\text { - Insaes }\end{array}$ & 8 \\
\hline Missão Cabo Verde & 6 \\
\hline Fonte: Elaboração própria com base nas atas públicas das reuniões ordinárias da Conaes (2011-2015).
\end{tabular}

Observa-se que, ao longo do período em que as atas das reuniões da Conaes passaram a serem publicadas, priorizou-se mais as discussões referentes à acreditação no Sistema Arcusul, ao Enade e à avaliação da EaD do que à autoavaliação institucional. Em artigo que traz reflexões sobre a autoavaliação com base na experiência da Conaes, Verhine (2013), 
corrobora os achados explicitados na tabela 4 reafirmando a não focalização dessa Comissão na autoavaliação e dando uma justificativa para isso. Segundo o autor,

[...] nos anos mais recentes, a maior parte das deliberações da Conaes tem focalizado a operacionalização dos processos de avaliação externa [...]. Tal foco é compreensível, pois a avaliação externa fica sob a responsabilidade do MEC, órgão ao qual a Conaes se vincula, e tem um papel fundamental no sentido de alimentar a regulação da educação superior efetuada pelo governo federal. Além disso, é importante considerar que, idealmente, a autoavaliação não deveria ser externamente imposta, de cima para baixo, pois precisa ter uma dinâmica própria, fundamentada na história, na cultura e na natureza da instituição, contando com a participação ampla de atores locais. (p. 53).

Obviamente, não se pretende questionar aqui o grau de importância da avaliação externa e das temáticas que emergiram das atas, mas apenas chamar atenção ao destaque que outras questões, entre as quais o Enade, têm ganhado em comparação ao que deveria ser o momento principal do Sinaes - a autoavaliação. Por mais plausível que seja a justificativa de Verhine (2013) para tal, a autoavaliação foi pouco assistida no decorrer da implementação do Sinaes e isso não pode ser ignorado.

$\mathrm{Na}$ academia, por sua vez, a contradição se repete. Todos os entrevistados representantes dos pesquisadores da área, por exemplo, consideram que se a autoavaliação funcionasse tal como previsto em Lei essa teria um significado central dentro da IES e do Sinaes como um todo. Um deles, inclusive, diz que "se você pegar os grupos que pesquisam a avaliação e reduzir a academia a isso, compreende que o processo de autoavaliação é o centro da avaliação das instituições." (P1, informação verbal). Contraditoriamente, ainda que se tenha isso como consenso geral, os mesmos entrevistados afirmam que a academia estaria em dívida com a temática da autoavaliação. Conforme um dos pesquisadores, os estudos da área de avaliação

[...] em geral estão baseados no Enade; no exame Enade; No IGC, CPC... Então acho que também a academia se perde aí. A questão da autoavaliação perde para o foco nos resultados esperados; nos resultados dessas provas, embora alguns trabalhos sim destacam o papel da autoavaliação. (P2, informação verbal).

Entre esses "alguns trabalhos", aos quais o entrevistado se refere, por sua vez, acrescenta-se o agravante deles estarem, em geral, segundo pesquisador da Unifesp, muito 
focados na proposta do Sinaes para a autoavaliação e não exatamente em como essa avaliação se processa em determinada instituição:

Quando nós fazemos o foco na autoavaliação ainda é uma dimensão pouco pesquisada. E quando se pesquisa sobre isso se discute muito o que é proposto. [...] Não há estudos em termos, eu diria, quantitativos que possam nos revelar um pouco de como a autoavaliação ela se processa nas instituições, qual realmente é o efetivo papel nesse processo... Então é uma dívida que a academia tem. (P4, informação verbal).

A autoavaliação não é objeto de estudo de muitos pesquisadores. Teixeira Júnior (2015) constata que essa avaliação vem sendo foco principal de interesse basicamente de apenas nove pesquisadores no país. O docente da UFSCar, entrevistado para esta pesquisa, disse que "se você quiser se especializar numa coisa interessante é esse processo de autoavaliação, que a academia em geral não faz muito estudo sobre esse processo.”. (P1, informação verbal).

Presencia-se, portanto, a implementação de uma avaliação ainda desconhecida ${ }^{64}$ para muitos; e que assim o é muito devido ao fato de, historicamente, pouco interesse se ter por ela. Mas esse desconhecimento - que inclui tanto o pouco que se sabe sobre o assunto; a pouca visibilidade e prioridade dada a ele; e, até mesmo, o ato de ignorá-lo e subsumí-lo a outras avaliações - é algo perceptível somente nas instâncias responsáveis e na academia? Da fala do representante da Daes/Inep, entrevistado, se infere que viria mesmo era da própria IES:

\begin{abstract}
A autoavaliação é um processo preponderante dentro do sistema, eu diria até que quando o Sinaes foi constituído o que se esperava era que a autoavalição se tornasse um processo principal e às vezes até demonstrasse a realidade, a qualidade da instituição por meio desse processo. Que a avaliação externa seria um complemento, mas o fator principal de avaliação da qualidade da instituição seria primeiro o relatório de autoavaliação. Mas aí durante o processo a gente viu o quê? Que a própria instituição acaba por dar mais interesse e valor pela avaliação externa, até mesmo pelo uso que tem em relação à regulação os atos autorizativos, e acabou por tornar-se um processo, em alguns lugares, claro, muito bem realizado, mas em outros com uma importância menor do que deveria ter tido com os princípios do Sinaes. O Sinaes coloca na autoavaliação a centralidade do processo avaliativo. (IN, informação verbal).
\end{abstract}

\footnotetext{
${ }^{64}$ Segundo o dicionário da língua portuguesa Houaiss; Villar, (2008), o adjetivo "desconhecido" significa (i) aquilo que não é conhecido ou se conhece pouco; (ii) que não tem fama; e/ou (iii) que se ignora. De acordo com outra fonte, esse adjetivo, respeitados contextos específicos, pode ser substituído por: ignorado, obscuro, misterioso, incógnito, ignoto, secreto, oculto e inexplorado. (DICIONÁRIO DE SINÔNIMOS, 2016). No decorrer desta seção se perceberá que muitos desses sinômimos, bem como todas as três significações para "desconhecido" se aplicam à autoavaliação. Desse modo, essa foi adjetivada como desconhecida.
} 
De acordo com essa fala, tem-se que o Inep percebeu com o tempo que as IES valorizam mais a avaliação externa à autoavaliação. No entanto, isso seria "culpa" das instituições? São elas que mesmo sabendo que a autoavaliação deveria ser o elemento protagonista, rebelam-se contra o sistema e o fazem coadjuvante? Diante de todo o contexto de maior apoio do Estado a avaliações controladoras; supervalorização do Enade; modificações apenas recentes na autoavaliação; e pouca discussão sobre o assunto por parte de instâncias responsáveis e também de pesquisadores, acredita-se que não ser possível identificar culpados. Se há uma espécie de crime contra uma das avaliações do Sinaes, esse foi cometido por muitos anos e com ajuda de vários cúmplices.

Infelizmente, se pode dizer que existe no país uma cultura de avaliação, vis-à-vis o histórico de projetos e políticas avaliativas, mas não se pode afirmar que exista uma cultura de avaliação formativa, tampouco de autoavaliação. O próprio entrevistado da Conaes é enfático ao dizer que "a base de tudo isso é uma questão cultural. Por que que eu digo isso? Porque nós não tínhamos esse processo avaliativo. Esse processo avaliativo ele não era utilizado como um instrumento de gestão acadêmica.”. (CO, informação verbal). Está-se diante, pois, de uma prática recente, não findada culturalmente e pouco assistida.

A autoavaliação aos moldes do Sinaes, contudo, como visto nas considerações iniciais desta pesquisa, embasou-se, sobretudo, nas experiências de duas instituições públicas que a iniciaram por iniciativa própria: UnB e Unicamp. Tendo a primeira como corpus desta pesquisa, se teve a oportunidade de perceber, entre outras questões, se os anos de sua prática autoavaliativa, bem como o fato de a IES ter sido inaugurada sob a idealização do pensador Anísio Teixeira, cujas ideias foram relatadas no capítulo 1, compensam e sobrepõem a realidade em que sempre se encontrou a autoavaliação no país.

Desde a sua formulação inicial, a avaliação desenvolvida pela UnB teve como um dos principais objetivos a busca do auto-conhecimento [sic] institucional, como um mecanismo para a tomada de decisão, com vistas ao aperfeiçoamento institucional e consequente demonstração, à sociedade, das "razões de ser da UnB" o que, no projeto, traduziu-se por uma prestação de contas à sociedade. (LOURENÇO, 1998, p. 46).

Neste contexto, na Universidade de Brasília a autoavaliação também seria desconhecida ou existiria na prática dessa IES uma cultura de avaliação formativa, que abraça a autoavaliação?

De fato, algumas instituições brasileiras apresentam uma autoavaliação aparentemente consolidada. O pesquisador da UFSCar e o representante do corpo docente da CPA da UnB 
citaram a UEG como exemplo de experiência exitosa de autoavaliação; o da Unifesp fez referência à PUC de São Paulo e o representante da Conaes exemplificou a UFMG e a UFRGS, por exemplo. No entanto, esses destaques parecem mais exceção do que regra. Enquanto todos os entrevistados citaram vários problemas referentes à autoavaliação de suas IES e de incontáveis outras, somente esses quatro apontaram, ainda que com dificuldade de memória, referências boas à autoavaliação. E na UnB, especificamente, desde a primeira fase prevista para a autoavaliação, vê-se que a essa avaliação não se está dando a assistência necessária. Verdadeiramente, se gostaria que só houvesse respostas afirmativas para perguntas como: (i) a constituição da CPA se dá sem problemas? (ii) a Comissão é atuante e consegue envolver a comunidade acadêmica? (iii) essa última reconhece a importância da autoavaliação? No entanto, mesmo sendo pioneira no que tange à autoavaliação e sendo uma instituição idealizada por renomado pensador, a realidade é que na Universidade de Brasília a exceção não se aplica; e a autoavaliação tampouco é conhecida ${ }^{65}$.

A grande realidade na política avaliativa da educação superior no Brasil é que a começar pelo momento de preparação da autoavaliação os desafios são enormes. Quando se cruzam as falas dos membros da $\mathrm{CPA}$ da $\mathrm{UnB}$ às dos pesquisadores e às dos membros da Daes/Inep e Conaes entrevistados vê-se que tanto na UnB como em diversas IES há muito que avançar.

O momento da preparação, conforme o documento "Orientações Gerais para o roteiro da auto-avaliação das instituições", pressupõe a constituição da CPA, o planejamento da autoavaliação por parte dessa e a sensibilização da comunidade acadêmica no trabalho autoavaliativo (BRASIL/Inep/Conaes, 2004b). Consequentemente, é algo que se dá continuamente e não de forma pontual quando se instituiu a autoavaliação. É no dia a dia que se nomeia um novo membro; que o mesmo escolhe continuar ou não na CPA; escolhe ser pontual, comprometido, preocupado com a instituição ou não; fazer seu trabalho de forma planejada ou sem planejamento; e ainda em parceria com a comunidade acadêmica ou independente dela, por exemplo.

De acordo com o Artigo 11 do documento "Sinaes - Sistema Nacional de Avaliação da Educação Superior: da concepção à regulamentação", a formação da CPA deve obedecer duas diretrizes, sendo a primeira:

\footnotetext{
65 Segundo o dicionário da língua portuguesa Houaiss, o adjetivo “conhecido" significa, entre outras considerações que referem-se especificamente à adjetivação de pessoas, (i) aquilo que muitos conhecem ou sabem; e (ii) algo célebre ou famoso. (HOUAISS; VILLAR, 2008).
} 
I - constituição por ato do dirigente máximo da instituição de ensino superior, ou por previsão no seu próprio estatuto ou regimento, assegurada a participação de todos os segmentos da comunidade universitária e da sociedade civil organizada, e vedada a composição que privilegie a maioria absoluta de um dos segmentos; (BRASIL/Inep, 2009, p. 157).

Desse modo, o primeiro momento da preparação, que seria a constituição da CPA deve dar-se pelos membros da comunidade universitária (docentes, discentes e corpo técnico), bem como pela sociedade civil organizada - que seria o membro externo ${ }^{66}$-; e ainda de forma equânime, em termos de representação dos segmentos. Tal composição, como reconhece o representante do corpo técnico da UnB, "é bem interessante porque nós temos pontos de vista muito diferentes". (TE, informação verbal). Os da sociedade civil organizada, recémempossados na CPA da instituição, por exemplo, conforme o próprio representante desse segmento disse, podem contribuir bastante

[...] no sentido de ter um olhar diferenciado daqueles que estão envolvidos no dia a dia com todo trabalho, com todas as questões que estão presentes na autoavaliação. Então, talvez, eu traga um olhar de fora. E quando você está de fora você consegue enxergar algumas coisas que são óbvias, mas não tão óbvias para quem está ali envolvido no processo. (SO, informação verbal).

É, contudo, muito difícil a escolha e permanência de representantes desse segmento, sobretudo. O que se percebe na prática é a dificuldade das instituições em ter, especialmente, representantes da sociedade civil organizada, visto que, a Lei do Sinaes apenas prevê a participação desse segmento, mas não especifica parâmetros para a escolha dos representantes. (MABA; MARINHO, 2012). O desejável é que essa categoria não seja representada somente por pessoas que sejam externas à IES, senão alguém que, além disso, esteja envolvida com a área da educação e representando uma comunidade ou uma associação.

Por conseguinte, como declara o representante da Daes/Inep entrevistado, há uma dificuldade muito grande para que se possa contar com essa categoria; e os membros das CPA do país, de um modo geral, relatam que o processo autoavaliativo sem eles "fica prejudicado porque acaba tendo uma visão somente de quem tá atuando internamente na instituição.” (IN, informação verbal). A UnB, segundo o representante docente, ficou sem esse tipo de membro por alguns meses. Conseguiu-se completar a CPA com todos os segmentos representativos no mês de fevereiro de 2016, a partir da Resolução da Reitoria n. 0014/2016, assinada pela vice-

\footnotetext{
${ }^{66}$ No Paru, primeira proposta de avaliação da educação superior, em nível de graduação, já se previa a participação da comunidade externa na autoavaliação, conforme visto no capítulo 2 .
} 
reitora Sônia Nair Báo, que nomeou dois membros da sociedade civil organizada. (UnB, 2016a).

Como se tal dificuldade já não fosse suficiente, a permanência desse e dos demais membros de uma CPA, pelo menos por um período de um ciclo avaliativo (três anos), por exemplo, tampouco é algo simples de se conseguir. A permanência por determinado período poderia proporcionar melhor continuidade no processo autoavaliativo, no entanto, de acordo com representante docente da $\mathrm{CPA}$ da $\mathrm{UnB}$, desde que esse entrou na Comissão (março de 2015), "metade da CPA foi nomeada, quer dizer metade permaneceu e metade... E, justamente, metade dos estudantes, metade dos funcionários, metade dos professores". (DO, informação verbal). Assim, além de ser trabalhoso compor a CPA, mantê-la também o é. A última nomeação de todos os membros da Comissão foi em 14 de outubro de 2013, por meio do Ato da Reitoria n. 0883/2013, instituído pelo Reitor, Ivan Marques de Toledo Camargo. Na ocasião, conforme previsto, 17 membros foram nomeados (UnB, 2013b). Não obstante, até o mês de junho de 2016, foram identificadas 14 substituições de membros. Em agosto de 2014, houve três (UnB, 2014); em março de 2015, sete (UnB, 2015a); em agosto de 2015, duas (UnB, 2015b); em dezembro do mesmo ano, uma (UnB, 2015c); e, por fim, em março de 2016, uma (UnB, 2016b).

Isso acontece, de acordo com os membros da Comissão da UnB e dos do Inep e Conaes, entrevistados, especialmente devido à falta de tempo dos membros para a dedicação ao processo de autoavaliação. Como mostra o representante da Daes/Inep, "lhes falta às vezes tempo destinado para essa atividade. Então, às vezes fica uma sobrecarga. Além das atividades de docência, das atividades de pesquisa, também tem a atividade da autoavaliação.”. (IN, informação verbal). Na UnB, especificamente, esse é um problema tão pungente que apareceu com uma frequência de seis vezes nas falas dos representantes docente, discente e técnico. Segundo o primeiro, a

[...] gente deixa de fazer nossas coisas acadêmicas pra dedicar o tempo; é um tempo grande aqui na universidade! A gente faz quarenta e poucas avaliações por ano; a gente recebe quarenta e poucos comitês de avaliação do ministério por ano e a gente tem que acompanhar esses processos. Hoje a tarde, por exemplo, eu vou pra um deles, então na verdade tira um tempo enorme do nosso trabalho. (DO, informação verbal).

É que nenhuma carga horária de suas funções rotineiras foi reduzida para que a função de membro da CPA entrasse em suas agendas. Mesmo o representante discente, por exemplo, que não tem vínculo empregatício com a instituição, também possui outras tarefas. Como 
estudante do doutorado da universidade, o discente entrevistado comenta que "muitas vezes a gente tem também que fazer pesquisa, tem que fazer outras coisas, mas sempre que posso eu estou lá na reunião e participando também dos eventos de avaliação.”. (DI, informação verbal).

Há, portanto, uma sobrecarga de trabalho e isso, somado à falta de estrutura para comportar as funções da CPA, torna-se um agravante maior. Compatibilizar a agenda de 17 membros (composição da CPA da UnB no primeiro semestre de 2016) que têm tempo escasso; e ainda sem contar com um local fixo para as reuniões ou com uma equipe de assessoramento grande, é uma realidade limitadora no contexto da UnB. Como comenta o pesquisador da UFSCar, uma CPA "teria que ter um grupo de apoio muito grande, o que em geral não tem.”. (P1, informação verbal). A da UnB conta com a colaboração de um grupo técnico denominado Grupo Técnico de Avaliação (GTA), instituído pelo Ato da Reitoria $n^{\circ}$ 362/2010. De acordo com sua última nomeação, que consta na Resolução da Reitoria $n^{\circ}$ 002/2015, o GTA possui a seguinte composição:

a) Diretor de Avaliação e Informações Gerenciais, Vinculado ao DPO, como coordenador; b) um representante do DPO c) dois representante do Decanato de Ensino de Graduação; d) dois representantes do Decanato de Ensino de Pesquisa e Pós-graduação; e) dois representantes do Decanato de Extensão; f) dois representantes do Decanato de Assuntos Comunitários; g) dois representantes do Decanato de Gestão de Pessoas; h) dois representante do Decanato de Administração; i) dois representantes da Prefeitura do Campus; j) dois representantes da Assessoria Internacional; k) dois representantes da Faculdade de Planaltina. (UnB, 2015, p. 27).

Mesmo com a garantia legal desse suporte à CPA dado pelo GTA, o representante docente diz que a Comissão precisava de mais ajuda. Para ele, a Comissão conta ainda com um grupo pequeno de assessoramento, "que é de estatísticos que nos ajudam um pouco com alguns trabalhos estatísticos e também com manusear esses bancos de dados do censo educacional, [...], mas a gente precisa de ajuda.”. (DO, informação verbal).

Contraditoriamente, nos relatórios de autoavaliação analisados, referentes a 2014 e 2015, essa dificuldade não é relatada, o que sinaliza que o processo autoavaliativo, o qual começa pela fase da preparação, culmina em um produto - relatório - não tão fiel à realidade. O último relatório, por exemplo, passa a ideia de que toda a instituição está empenhada em auxiliar a CPA. Em item sobre o plano estratégico de autoavaliação consta o seguinte:

Para dar o suporte administrativo necessário e promover a continuidade de ações relacionadas à avaliação, há também a Diretoria de Avaliação e 
Informações Gerenciais, a Coordenação de Avaliação do Ensino de Graduação, a Diretoria de Desenvolvimento Institucional e Inovação e a Coordenação de Avaliação da Produtividade de Extensão. Todos esses setores possuem, conforme sua área de competência, o dever de promover ações avaliativas que possam garantir controle e subsidiar melhorias aos processos. (UnB, 2016, p. 24).

Muito diversa, a realidade da UnB é a da falta de suporte e de apoio à CPA. Vianna (2013), baseando-se na realidade da autoavaliação do Instituto Federal de Educação, Ciência e Tecnologia de Santa Catarina - IFSC e na literatura da área, diz que algumas das dificuldades pelas quais as CPA, de modo geral, passam são: (i) não contar com apoio logístico - salas, materiais, equipamentos, (ii) não ter suporte técnico adequado - tecnologia da informação e comunicações, estatística, softwares, etc.; e (iii) não receber apoio logístico por parte dos dirigentes da IES. Conforme o autor, à medida que a CPA ajuda a mostrar pontos fracos da gestão, atingindo cargos diretivos, "poderá inexistir qualquer apoio logístico ao processo e à equipe; é lógico que o escalão superior não queira dar "munição" a quem vai "detoná-los"." (VIANNA, 2013, p. 10).

A respeito da UnB não se pode afirmar que a carência de apoio à Comissão ocorra, necessariamente, por algum receio da gestão em auxiliar quem pode prejudicá-los. No entanto, o fato é que, sob a perspectiva da CPA, o trabalho de autoavaliação merecia e deveria acontecer com muito mais apoio do que realmente ocorre. Como desabafa o representante do corpo técnico, além das dificuldades logísticas, "a questão é que você não tem um tempo; se você tivesse, suponhamos, "eu tenho 4 horas por semana dedicadas a CPA”, já é um ponto de partida. A CPA tem uma sala? Na CPA a gente não tem nada disso!” (TE, informação verbal).

Segundo entrevistado da Conaes, há um movimento para mudar esse panorama e melhorar a infraestrutura do ambiente de trabalho das CPA do país. Para ele, especialmente as instituições federais estão "dando hoje infraestrutura, estão dando hoje uma secretaria executiva, e quando eu falo de infraestrutura eu estou falando de infraestrutura física, né? De equipamentos, com suporte, hoje, de pessoas, de secretárias, que não existia antes.". (CO, informação verbal). Contudo, tudo indica que atenção especial da gestão a isso ainda deve ser dada na UnB, bem como em diversas outras instituições do país.

Acrescenta-se que a CPA, no que tange a sua formação, ainda tem dificuldades com relação à autonomia. No mesmo artigo 11 do documento "Sinaes - Sistema Nacional de Avaliação da Educação Superior: da concepção à regulação", outrora aludido, consta que a segunda diretriz que a formação da CPA deve obedecer é a "II - atuação autônoma em relação a conselhos e demais órgãos colegiados existentes na instituição de educação superior.”. 
(BRASIL/Inep, 2009, p. 157). Segundo representante da Conaes, é preciso que a Comissão “tenha certa independência em relação à instituição, em relação à mantenedora, no caso da instituição privada; no caso da instituição pública também ter certa independência em relação à gestão central.”. (CO, informação verbal). Contudo, na prática, de modo geral, isso não é sempre possível.

Agir com autonomia, segundo P3 - um dos pesquisadores da área entrevistados - é mostrar tanto as questões positivas como as negativas da instituição. Afinal, o artigo 12 da Lei 10.861/2004 foi claro ao dizer que os responsáveis "pela prestação de informações falsas ou pelo preenchimento de formulários e relatórios de avaliação que impliquem omissão ou distorção de dados a serem fornecidos ao SINAES responderão civil, penal e administrativamente por essas condutas.”. (BRASIL, 2004a, art. $12^{\circ}$ ). Não obstante, fazer isso não é tão simples.

Se a Comissão cumprisse o que se fala na lei do Sinaes ela teria mais poder que o reitor, ou, pelo menos, um poder muito próximo ao do reitor. Porque você avaliar o processo e divulgar esses resultados e propor ações de melhoria e tudo mais é quase um poder próximo ao do reitor. (P1, informação verbal).

Desse modo, a CPA seria, de certa forma, uma ameaça à gestão da instituição, já que desnudaria o trabalho dessa e ainda tornaria isso público. Na Universidade de Brasília, ainda que não se possa assegurar tal motivação, ter autonomia é um desafio constante. Até o ano de 2012 o presidente da CPA da UnB era necessariamente o reitor. Foi somente com a aprovação da Resolução do Conselho Universitário n 31/2013 que a partir do ano de 2013 o presidente passou a ser um dos membros da Comissão, devendo ser um docente ou técnicoadministrativo. (UnB, 2014).

No PDI 2014-2017 da instituição consta que a partir do ciclo de gestão que começaria com o projeto de 2014, em questão,"pretende-se reafirmar a importância dessa comissão na UnB, garantir sua autonomia, ampliar sua atuação e resguardar seu espaço na definição e operacionalização de diretrizes e estratégias da Universidade.”. (UnB, 2014, p. 94). Mesmo assim, conforme representante técnico administrativo, em 2016 o trabalho da CPA na UnB está sendo desenvolvido com a consciência de que não haverá consenso sobre os resultados, já que especialmente por essa ser uma universidade, "é tudo muito questionável na metodologia, tudo está muito a flor da pele, todo mundo sabe de tudo". (TE, informação verbal).

Ainda segundo o PDI da universidade investigada, o foco principal da autoavaliação é o cumprimento da missão institucional, qual seja, no caso, formar pessoas; logo, é natural que 
a CPA levante dados, discuta e publique questões referentes à evasão, retenção, egresso, etc. Esses temas, porém, segundo entrevistado do corpo técnico, seriam muito sensíveis, já que envolvem o trabalho de pessoas altamente qualificadas, que além de questionarem a competência da Comissão, não querem ver seus próprios trabalhos expostos. Basicamente, então, sente-se

[...] dificuldade de tratar de assuntos tão delicados com pessoas que são responsáveis pela gestão, não só da implementação das melhorias, mas também respondem pelas eventuais falhas. E a CPA eu acho que na verdade ela não é tão bem vista, assim, porque ela acaba expondo algumas fragilidades que os gestores não querem; ou [...] como há outras formas de calcular, outros pontos de vista, o resultado que a comissão apresenta sempre é passível de muitas críticas. (TE, informação verbal).

Em suma, para esse entrevistado, a CPA nota que a gestão atual da UnB, “que assumiu no final de 2012, [...] eles conseguem ver a avaliação, a autoavaliação, com bons olhos" (TE, informação verbal), mesmo assim, de sua fala também se infere que a CPA, ainda que legalmente autônoma dentro da estrutura da universidade, não o é na prática.

O ambiente no qual a CPA se constitui e desenvolve a autoavaliação, em suma, é repleto de embates. No PDI 2014-2017 da instituição a gestão é enfática ao afirmar que o apoio da administração superior é fundamental para o sucesso dos empreendimentos relacionados à autoavaliação, sendo preciso "ampliar o espaço da avaliação e da Comissão Própria de Avaliação nos principais colegiados da instituição, reforçando a importância, as vantagens, o acompanhamento realizado e os resultados alcançados por meio da avaliação institucional.”. (UnB, 2014, p. 94). Na rotina que envolve a CPA, contudo, não se vê, na prática, a implementação dessa proposta.

Em um ambiente de autonomia ou não, estruturado ou não e com todos os membros representativos de cada segmento ou apenas alguns deles, a CPA tem que funcionar de alguma forma. O ideal é que as atividades comecem pela realização de um "planejamento das ações mediante plano de trabalho que inclua cronograma, distribuição de tarefas e recursos humanos, materiais e operacionais.”. (BRASIL/Inep/Conaes, 2004b, p. 8). Não obstante, conforme representante da Daes/Inep, as IES têm dificuldade em realizar um planejamento de autoavaliação; e, segundo pesquisador entrevistado, há "trabalhos que falam e também comentários de instituições que contratam consultor para fazer projeto de autoavaliação sem envolver nenhum processo participativo institucional”. (P2, informação verbal). 
Esse não é o caso da UnB. Aautora deste trabalho teve a oportunidade de participar de uma das primeiras reuniões da CPA do ano de 2016 e constatou que o planejamento é feito conjuntamente entre os membros presentes, pelo menos. As reuniões acontecem, em média, uma vez ao mês e todo o cronograma de atividades a serem realizadas individualmente ou em conjunto é discutido em equipe. A dificuldade marcante do momento específico das reuniões, segundo representante dos técnicos administrativos, é mesmo manter o foco no trabalho de autoavaliação. Segundo esse, as reuniões são agendadas

[...] com muita antecedência, porque tem que compatibilizar agenda; e aí hoje em dia, com tecnologia, é mais fácil, vai no whatzap e tudo, mas é difícil, por exemplo, concentrar: "agora é a hora da reunião, foco!". É uma coisa que eu sinto muita falta, porque já que o tempo é escasso a gente precisa tá bem focado, e não é fácil, então essa questão de não ter um tempo próprio para a CPA e não ter às vezes uma estrutura formal muito grande com muitos membros também acaba não ajudando. (TE, informação verbal).

Assim, ainda que se perca tempo em certos momentos por falta de concentração, se consegue fazer planejamentos em relação à autoavaliação. O difícil mesmo na UnB não é exatamente planejar esse processo, senão pô-lo em prática. Para contemplar a fase da preparação da autoavaliação, é preciso sensibilizar os envolvidos, buscando "o envolvimento da comunidade acadêmica na construção da proposta avaliativa por meio da realização de reuniões, palestras, seminários, entre outros.”. (BRASIL/Inep/Conaes, 2004b, p. 10). Em outras palavras, seria mostrar à comunidade acadêmica o trabalho da CPA, para, assim, tê-la como aliada durante todo o ciclo avaliativo. Quando do começo da implementação da avaliação na UnB, na década de 1980, a fim de se sensibilizar a comunidade acadêmica, tanto foram enviadas cópias do plano de avaliação às chefias dos departamentos, como "feitas visitas a todos os diretores de institutos e faculdades no sentido de trocar ideias com relação à questão da avaliação, tanto do ponto de vista da receptividade quanto da divulgação e apoio junto aos departamentos.”. (BELLONI; KIPNIS; SERAFINI, 1980, p. 17). Desse modo, alguns podem se perguntar se a falta de conhecimento sobre a importância da autoavaliação seria um problema na UnB na atualidade, estando a sensibilização presente desde o início. Porém, para surpresa de muitos, esse não só é um problema como um dos maiores. Nessa universidade é preciso tanto sensibilizar a comunidade acadêmica em questão sobre a importância da autoavaliação, como mostrar-lhes o que é esse processo avaliativo. A consequência disso é prejuízo à continuidade do processo avaliativo. 
Argollo (2010) buscou analisar a implementação da autoavaliação no período de 2004 a 2009 em 16 IES que compunham à época da Rede Federal de Educação Tecnológica, por meio de entrevistas com os coordenadores das CPA de cada instituição selecionada. A autora percebeu, de modo geral, que as comissões exercem relativa autonomia na condução do processo avaliativo, mas que a participação da comunidade interna e externa no processo era incipiente, já que poucas pessoas conheciam a autoavaliação. Para ela, isso prejudica a legitimidade e continuidade do momento avaliativo dessas 16 IES; e para a autora desta pesquisa, visto que o mesmo acontece na UnB, o processo dessa última também está comprometido.

Até os próprios membros da CPA nem sempre conheciam a autoavaliação antes de se juntarem à Comissão. Os entrevistados representantes do corpo discente e da sociedade civil organizada - esse último, ex-estudante de pós-graduação em Educação da UnB -, por exemplo, declaram que na condição somente de estudantes não conheciam a CPA e seu trabalho. Se eles, que se interessam por avaliação, não conheciam esse processo, o que dizer da comunidade acadêmica como um todo?

Conforme representante do corpo docente, "a gente pede pra preencher algum formulário, alguma coisa, dar algum tipo de informação, as pessoas simplesmente se fecham, não sabem nem o que é". E de acordo com o representante discente, apesar da entrada recente na CPA da UnB, ele entende, como ex-estudante da IES, que

[...] os diversos segmentos ainda não têm a compreensão, não conhecem de fato, não têm a compreensão da importância da autoavaliação para a instituição e pra si próprio. Tanto docente, quanto discente, quanto gestão, eu acho que ela [a autoavaliação] incide diretamente no trabalho de todos esses segmentos, então eu acho, basicamente, que não conhecem. (SO, informação verbal).

A tarefa da sensibilização, nesse caso, fica duplamente difícil, já que, em geral, a comunidade acadêmica sequer conhece a autoavaliação e o trabalho da CPA. É que, como mostram Freitas e Cunha (2010), quando

[...] a cultura avaliativa formativa, reflexiva, emancipatória já faz parte da rotina da IES, a sensibilização, de certo modo, é automática. Os sujeitos envolvidos se vêem participantes já de modo organizado. Quando não há essa cultura avaliativa, é preciso criar estratégias de sensibilização que amenizem a resistência e o descrédito que se observam em todas as etapas do processo de autoavaliação. (p. 15). 
$\mathrm{Na} \mathrm{UnB}$, como relata o representante discente, alguns estudantes ainda relacionam, equivocadamente, qualquer avaliação à punição - reflexo provável do que se discutiu no capítulo sobre a sobreposição da regulação sob a avaliação formativa. Segundo o mesmo representante, quando acontece algum problema com determinado professor, por exemplo, o estudante o avalia e "coloca que o professor foi ruim e tal; faz uma autoavaliação bem rigorosa com o professor. Aí no semestre que vem ele diz assim "mas esse professor ainda está aqui?"." (DI, informação verbal). Outros, segundo o representante técnico administrativo, veem a autoavaliação com profunda descrença. Para esse entrevistado, "se a gente for falar da massa [da comunidade acadêmica], da grande massa, eu acho que ainda é com muita descrença. Eu acho que as pessoas ainda se perguntam: "por que que eu tenho que responder isso?”; “o que vocês vão fazer com isso?”; "não muda nada”. (TE, informação verbal).

Os vestígios de anos de práticas avaliativas não formativas encontram-se, portanto, internalizados na concepção que a comunidade acadêmica tem sobre avaliação. Mais que sensibilizar sobre a importância da autoavaliação, fica à CPA o desafio de ajudar na ressignificação do conceito avaliativo. Ao mesmo tempo, então, que os membros da Comissão precisam apropriar-se do significado da autoavaliação - algo novo para alguns também devem encontrar mecanismos para passar isto adiante, difundindo o seu trabalho e a importância do processo autoavaliativo. Conforme o membro da Conaes, entrevistado, a sensibilização é o caminho fundamental para fomentar a participação; e, com base nas falas dos entrevistados da UnB, a CPA já percebeu isso.

Os membros de todos os segmentos consideram a autoavaliação como processo de extrema importância e necessidade. Para o representante da sociedade civil, a autoavaliação é "o centro em relação aos outros dois níveis de avaliação que existe no processo educativo." (SO, informação verbal). Para o representante docente, ela é uma forma, por exemplo, de se zelar pelo bom investimento do recurso público aplicado na universidade - o que se aproxima diretamente da concepção de qualidade defendida por Scriven (1991), explanada no capítulo 1. E para o entrevistado do segmento discente, a autoavaliação é imprescindível para que se obtenham melhorias na instituição. Assim, a Comissão tenta, como pode, promover ações de conscientização da UnB.

Ao que tudo indica, a "grande massa" da UnB não conhece esse processo avaliativo (TE, informação verbal); enquanto isso, especialmente a gestão da instituição poderia até estar temendo seus resultados. A CPA, então, vem sentindo a necessidade de, de certa forma, prestar contas de suas ações a IES, fazendo, ao mesmo tempo, um trabalho de sensibilização. As medidas em andamento ou projetadas para um futuro próximo são, segundo os membros 
entrevistados, quatro: (i) devolutiva das consultas realizadas com a comunidade; (ii) boletim bimestral do trabalho da CPA; (iii) fóruns sobre autoavaliação; e (iv) CPA itinerante ${ }^{67}$. A essas se acrescenta a criação do site da CPA em setembro de 2015, ação prevista pelo PDI 2014-2017 e relatada no último relatório de autoavaliação. (UnB, 2016). O site <www.cpa.unb.br> contem informações sobre a composição da Comissão, os processos autoavaliativos desenvolvidos, dados sobre pesquisas realizadas etc. e, segundo descrição do relatório de autoavaliação, já obteve aproximadamente mil acessos. (UnB, 2016).

Além dessa ação, identificada a resistência da comunidade às consultas realizadas pela CPA, fez-se, uma vez, como disse o representante do corpo técnico administrativo, devolutiva da consulta. Nessa constava os resultados a que se chegou; e os interessados tinham a oportunidade de opinar a respeito. Segundo o entrevistado, tal iniciativa seria feita novamente em 2016 e, a partir disso, espera-se "que, com o tempo, a gente vá ganhando credibilidade". (TE, informação verbal).

Outra iniciativa que também, de certa forma, é uma devolutiva, foi a criação e distribuição de um boletim trimestral contendo um resumo do que vem sendo realizado pela Comissão. A ideia de fazê-lo se deu muito pelo fato de que, como conta o representante docente referindo-se ao relatório de autoavaliação, "ninguém vai ler uma coisa tão grande" (DO, informação verbal). Sobre os relatórios se falará no tópico seguinte, contudo, já se adianta que nessa espécie de síntese do relatório, a qual já está sendo publicada e divulgada na instituição, depositam-se expectativas quanto ao reconhecimento da comunidade sobre o que é a autoavaliação e sua importância.

Além disso, tem-se a realização de um fórum sobre autoavaliação, iniciativa que teve sua terceira edição em 2016. O nome do evento é "AVAL - Fórum da Comissão Própria de Avaliação" e, basicamente, de acordo com docente entrevistado, é um seminário de um dia, aberto à comunidade, mas com foco na participação dos coordenadores de curso, ocasião em que "nós apresentamos várias informações. Não só nós da CPA, mas o decanato com pessoas envolvidas [...] de alguma forma, com o que a gente está estudando.” (DO, informação verbal). De acordo com o relato colhido, esta experiência é bastante válida, permitindo que boa parte do público se inteira do que é a autoavaliação nesse fórum. A adesão ao evento, contudo, não é tão grande. Como consta nos relatórios de autoavaliação referentes aos anos de 2014 e de 2015, a primeira edição do evento, em 2014, contou com a participação de 77 pessoas, sendo 54 professores, 17 técnicos administrativos, 4 estudantes e 2 ex estudantes; já

\footnotetext{
${ }^{67}$ Segundo o dicionário da língua portuguesa Houaiss; Villar (2008), o adjetivo "itinerante" significa aquele que viaja, que se desloca, que faz deslocamentos sucessivos de lugar em lugar.
} 
a segunda, no ano subsequente, apresentou pequeno aumento do número de participantes. Estavam presentes 81 pessoas, sendo 48 professores, 19 técnicos-administrativos, 13 estudantes e 1 pessoa da comunidade externa. (UnB, 2015; 2016)

A fim de retroalimentar o fórum com sugestões, é enviado via e-mail um questionário a todos os participantes. Na primeira edição, 23 formulários foram respondidos, totalizando $28 \%$ do total de participantes; na segunda edição, por sua vez, 30 foram respondidos, o que corresponde a $40 \%$ das pessoas. (UnB, 2015; 2016). Entre as sugestões, destacam-se duas que se repetiram em ambas as edições: (i) aumentar a participação da comunidade acadêmica no evento e (ii) focar mais na apresentação dos resultados práticos da autoavaliação. Quem participa do Fórum e tenta sugerir melhorias ao mesmo deseja, portanto, que outras pessoas da comunidade conheçam o trabalho da CPA e saibam os resultados desse trabalho. O representante técnico administrativo, entrevistado, acredita que "a medida que a gente for, enfim, buscando consolidar esse e outros eventos a gente possa vir a alcançar um numero maior, mas ainda é um trabalho que não atrai muita gente.”. (TE, informação verbal).

Por fim, uma última iniciativa aludida pelos membros entrevistados foi o que eles denominam de "CPA itinerante", ação recente explanada somente no último relatório de autoavaliação (UnB, 2016) e que vem para atender à proposta do PDI da IES (UnB, 2014). A CPA da UnB, como qualquer outra, deveria fazer a mediação entre as decisões da gestão e as expectativas da comunidade acadêmica; no entanto, contraditoriamente, a Comissão ainda não se fez presente nos outros campi da IES que não o da sede. Apesar de a formação da CPA, até a publicação do relatório referente a 2015, contar com dois membros da Faculdade de Ceilândia (um docente e um representante técnico administrativo), um da Faculdade do Gama (docente) e um da Faculdade de Planaltina (técnico administrativo), e de incluir toda a instituição na coleta de dados, a Comissão vem privando-se a implementar as iniciativas de sensibilização, anteriormente aludidas, somente no campus Darcy Ribeiro - na Asa Norte -, onde concentra-se a maior parte dos cursos. Apenas a partir de 2016, com o deslocamento dos membros da CPA até os campi de Planaltina, Gama e Ceilândia a aproximação e conscientização poderão ficar equânimes. O que se vivencia, portanto, é uma aproximação da CPA com a comunidade e tentativa de criação de laços consistentes entre ambas, tal como se fazia no momento de implementação inicial da avaliação institucional na UnB.

Assim, se baseados na sede da instituição, os membros afirmam que a comunidade acadêmica não conhece a autoavaliação, é possível facilmente acrescentar à lista os estudantes e trabalhadores dos outros campi. As expectativas quanto à implementação da CPA itinerante são, contudo, grandes. A meta para o ano de 2016 é que 
[...] a CPA saia do campus Darcy Ribeiro, que é o maior, e visite outras unidades; e que a gente possa, com os dados que a gente tem, tratar das realidades locais e tentar fazer com que essas pessoas se sintam parte desse processo de autoavaliação; que elas confiem nesse processo e que elas ajudem a construir as melhorias. Mas só coleta, por si só, não resolve, a gente sabe que se a administração não comprar a autoavaliação aí realmente o descredito é grande. (TE, informação verbal).

Essa meta e as iniciativas em andamento têm, pois, em comum, a ideia de explicar à comunidade o que é a autoavaliação e a importância dessa; sempre tomando "comunidade" como todos os segmentos constituintes da instituição, entre os quais a gestão. É essa última, especialmente, sobre a qual, na UnB, deveria recair as iniciativas de sensibilização, pois, sobretudo ela é que especialmente precisa, na visão dos entrevistado da IES, enxergar a CPA como aliada de seu trabalho.

Segundo P3 - um dos pesquisadores entrevistados -, o desejável era que as equipes de gestão das IES, em geral, colocassem a autoavaliação como prioridade, que valorizassem o processo, que acompanhassem este e que compreendessem que a prática autoavaliativa é necessária e deve ter relação direta com o planejamento institucional. A realidade, contudo, nem na UnB, nem, possivelmente, em outras instituições, é essa. Segundo outro pesquisador entrevistado, no

[...] caso da UFSCar a reitoria tinha um grande programa de avaliação no nosso grupo de gestão que não conversava com a avaliação da CPA. Daí na realidade as pessoas fazem... muitas vezes as pessoas têm a necessidade de avaliação, mas fazem independente da CPA. (P1, informação verbal).

De fato, conforme Rothen et. al. (2013), a atuação da CPA da UFSCar em um recorte temporal de 2006-2012 foi até significativa para "a melhoria dos processos formativos em nível de graduação, mas não isoladamente. Os progressos identificados são resultantes de parceria da CPA com os demais setores da universidade, bem como do estabelecimento de políticas e ações institucionais.”. (p.1-2). Segundo pesquisador dessa IES, entrevistado, aconteciam dois processos de avaliação interna "porque ela [a CPA] não tem condições técnicas/humanas de fornecer ajuda às pessoas, de quando as pessoas precisam fazer avaliação a CPA [estar] lá, ajudando.”. (P1, informação verbal). Todavia, talvez, caso se experimentasse depositar confiança na Comissão e dar a ela subsidio - em termos de tempo e estrutura - para que a mesma se desenvolvesse, possivelmente seria uma iniciativa mais sábia.

Na Universidade de Brasília, especificamente, tanto se analisando o currículo Lattes dos membros da CPA dessa, como auscultando os depoimentos dos selecionados para 
entrevista semiestruturada, vê-se que, em geral, a equipe tem muita experiência na área de gestão, podendo, por conseguinte, vir a auxiliar de forma bastante consciente. Como diz o representante do corpo técnico-administrativo, "nós temos pessoas que entendem de fato de gestão, então a gente não vai ficar discutindo só o cenário ideal. Eu acho que não é esse nosso propósito; a gente tem pessoas muito maduras na nossa equipe.”. (TE, informação verbal). Entretanto, a grande questão é que não há suporte, confiança, nem incentivo no cenário da autoavaliação da instituição. $\mathrm{O}$ próprio representante do corpo discente desabafa que os membros da CPA estão "lá de boa vontade mesmo, sabe? Então, não tem, assim; a gente tem uma Portaria, a gente coloca no currículo que a gente participa... Muito de boa vontade, todos os professores ali, todas as pessoas que estão lá naquele trabalho é isso.” (DI, informação verbal).

$\mathrm{Na}$ ata da $89^{\circ}$ reunião ordinária da Conaes, de agosto de 2012, analisada para esta pesquisa, o então presidente dessa Comissão, professor Robert Evan Verhine, salientou que quando se aprecia a "literatura do Sinaes, a sua base é a autoavaliação; e a CPA é a responsável por esta. Então, é preciso se trabalhar não no sentido de impor, mas no sentido de orientar e criar ambientes em que a CPA possa avançar e consolidar a autoavaliação das instituições." (CONAES, 2012). Situando o debate no contexto da UnB como foco, e tendo todas as considerações levantadas neste tópico como base, a fala do ex-presidente da Conaes não poderia ser mais atual e adequada.

A Universidade de Brasília, como sintetiza entrevistado representante do seu corpo técnico-administrativo, "está passando por um processo muito positivo de amadurecimento da autoavaliação". Vê-se que, ainda que como práticas recentes ou apenas planejamento, há ações, por parte da Comissão Própria de Avaliação da instituição, que tentam dar um significado maior à autoavaliação, significado esse, que muitas vezes ainda está em construção também entre seus membros. Esses, como visto, têm muitas dificuldades tanto no que tange à formação da CPA, como à sensibilização da comunidade acadêmica sobre a importância do trabalho desta. Criar um ambiente mais favorável ao desenvolvimento do trabalho da Comissão seria, portanto, um avanço que auxiliaria muito o trabalho da autoavaliação e o alcance desse. 


\subsection{PROCESSO AUTOAVALIATIVO E SEUS RESULTADOS: O EMBATE ENTRE AS FUNÇÕES FORMATIVA E BUROCRÁTICA DOS RELATÓRIOS}

A segunda fase da autoavaliação, sob as diretrizes do Sinaes, é o desenvolvimento, a qual consiste na concretização das atividades previstas na etapa anterior, de planejamento. Nesse momento, a CPA tenta assegurar a coerência entre as ações planejadas e as metodologias adotadas, bem como criar uma articulação entre os colaboradores e os prazos. (BRASIL/Inep/Conaes, 2004a; 2004b). Tais ações não são, contudo, de simples implementação. Para Soares Neto et. al. (2013), que descrevem a proposta de autoavaliação institucional da UnB, produzida para o triênio 2011-2013,

[...] o desafio de desenvolver uma metodologia para avaliação institucional de uma universidade é tão grande e complexo quanto a própria instituição. As múltiplas funções da universidade, representadas pelo trinômio ensinopesquisa-extensão, e a complexidade de sua gestão colegiada impõem ao processo de avaliação a necessidade de desenvolver uma metodologia que permita fazer julgamento de valor das diferentes atividades, de tal forma que a própria metodologia esteja livre de viés pela seleção de um aspecto a partir do qual se valorizará ou não a instituição, independente do valor ou da relevância das demais atividades desenvolvidas. (p. 6).

Prevê-se que a CPA, nessa fase, não atue de forma controladora, contando, pelo contrário, com participação reflexiva da comunidade acadêmica, assim como fica explicitado de forma mais incisiva na fala de pesquisador da Unifesp, entrevistado:

Então, é o seguinte, entendendo que a avaliação implica o autoconhecimento da instituição, eu considero que a Comissão Própria de Avaliação tem que fazer um movimento para que no mínimo os representantes das diversas áreas possam participar desse produto, desse processo de avaliação. Tanto os setores envolvidos especificamente com a formação que se constrói na universidade, os setores envolvidos com pesquisa, os setores envolvidos com a extensão, e os setores envolvidos com a própria gestão acadêmica. Partindo do princípio que a autoavaliação, ou a própria avaliação no sentido mais amplo, deve ser participativa, deve ser construída no coletivo, eu não consigo perceber uma CPA que seja uma CPA centralizadora [...]. (P4, informação verbal).

É preciso, portanto, trazer a comunidade acadêmica para o processo avaliativo como a parceira principal da CPA, fazendo da autoavaliação uma atividade presente no cotidiano da IES. Afinal, como mostra Cunha (2013, p. 12), é fundamental “construir espaços para participação efetiva de todos aqueles que avaliam e são avaliados. Construir esse exercício de 
participação é enfrentar a realidade e assumir que só se aprende a fazer, fazendo, nesse caso, só se aprende a participar, participando.”.

Em um ambiente participativo, ao responder, a pedido da Comissão Própria de Avaliação, a um questionário ou entrevista, por exemplo, a comunidade compreenderia o porquê e a importância da autoavaliação. Contudo, baseado em suas leituras e na experiência da própria Unifesp, o entrevistado dessa IES diz "que se você pegasse um grupo de alunos eles vão dizer assim: "ah eu preenchi um formulário não sei quando..." Nem os professores valorizam!” (P4, informação verbal). Segundo o mesmo,

[...] nem sempre os nossos colegas [docentes], os nossos alunos, por inúmeras razões, têm a clareza do significado do papel que deve ter no processo de autoavaliação. Então eu imagino que [os membros da CPA] teriam dificuldade tanto para agregar as pessoas para pensarem isso e não apenas para apresentar um conjunto de dados. (P4, informação verbal).

E a suposição desse investigador entrevistado, longe de ser algo que não se viabiliza, realmente acontece e tem grande peso sob a autoavaliação, como alguns estudos já apontaram. Queiroz (2008), por exemplo, objetivando analisar o processo de implementação da autoavaliação na Unidade Universitária de Ciências Sócio-econômicas e Humanas (UnUCSEH) - Unidade Acadêmica da Universidade Estadual de Goiás (UEG) -, demonstra que além das carências de infraestrutura e de recursos financeiros à autoavaliação, na IES em questão não há protagonismo da comunidade acadêmica no processo, configurando uma participação passiva - fator que ela considera como inibidor do processo avaliativo.

Souza e Méxas (2014), por sua vez, objetivam perceber como a dimensão "responsabilidade social" é trabalhada na autoavaliação empreendida pela Unidade de Ensino Descentralizada de Nova Friburgo, que integra o Centro Federal de Educação Tecnológica do Rio de Janeiro (CEFET-RJ). Eles aplicaram um questionário a uma mostra de discentes, docentes e técnicos administrativos da IES; e a partir da análise das respostas, concluíram, entre outras questões, que "a participação da comunidade acadêmica está restrita às reuniões de colegiados ou à discussão de assuntos específicos.”. (p. 354). E isso não configura de acordo com os autores uma participação desejável. A participação que se espera é aquela que reflete uma comunidade acadêmica crente na importância do trabalho da CPA e no que se pode alcançar com esse. Em muitas realidades, como as que Queiroz (2008) e Souza e Mexas (2014) mostram, o significado atribuído à autoavaliação não é o desejado.

$\mathrm{Na} \mathrm{UnB}$, como visto na seção anterior, a comunidade acadêmica, de modo geral, nem sabe o que é a autoavaliação e a CPA. A sensibilização vem ocorrendo, especialmente 
encabeçada pela própria Comissão, a qual, por exemplo, criou o fórum Aval e pretende visitar os outros campi da instituição por meio do projeto "CPA itinerante", contudo, o impacto dessas ações ainda não ganhou uma abrangência perceptível. Entre as práticas já consolidadas no processo autoavaliativo da $\mathrm{UnB}$, aferidas das entrevistas realizadas para a pesquisa e da parte referente ao Eixo 1 (Planejamento e Avaliação Institucional) do relatório de autoavaliação de 2015, destaca-se: (i) a consulta à comunidade, realizada pela CPA e com abrangência nos três segmentos que formam a comunidade acadêmica (docentes, discentes e técnicos-administrativos); e (ii) o questionário dos discentes, ${ }^{68}$ aplicado pela gestão, mas utilizado nas análises da Comissão - ambos de preenchimento facultativo.

A consulta à comunidade é realizada por meio de questionários aplicados por meio eletrônico, os quais contêm perguntas sobre: infraestrutura, serviços, imagem da instituição, comunicação com a sociedade e ações de capacitação, por exemplo; dados que são posteriormente organizados pelo GTA. Já o questionário dos discentes, promovido pela gestão, é dividido em quatro partes: (i) avaliação da disciplina, (ii) do desempenho do professor, (iii) autoavaliação do estudante e (iv) apoio institucional à disciplina, sendo desde o segundo semestre de 2011 aplicado junto ao sistema de matrícula online. (UnB, 2015).

Apesar de os questionários da CPA e da Gestão serem distribuídos periodicamente, a participação da comunidade é incipiente. Nem todos respondem; e, ao que tudo indica, um dos motivos disso é o fato de algumas partes dos instrumentos serem grandes ou bastante burocráticas. Sobre o questionário da gestão aplicado aos discentes não se tem dados numéricos da quantidade de respondentes, porém, o representante discente entrevistado comentou, lamentando, que o estudante "faz esse questionário e ele também pode não responder questionário nenhum; são varias páginas, ele pode não responder questionário nenhum.”. (DI, informação verbal). O tamanho do instrumento, então, parece ser um fator limitador à participação.

No caso da consulta à comunidade, realizada pela CPA junto aos docentes, discentes e corpo técnico da instituição, tem-se que apesar de a comunidade acadêmica da UnB ser formada por mais de 50 mil pessoas (UnB, 2016), os questionários aplicados em fevereiro de 2015 contaram com a participação de 1.399 pessoas, sendo 363 docentes, 460 técnicoadministrativos e 576 estudantes (UnB, 2015); e o aplicado entre janeiro e março de 2016, por sua vez, contou com a participação de 1.465 pessoas, sendo 364 docentes, 407 técnico-

\footnotetext{
${ }^{68}$ As informações coletadas no questionário do discente "são organizadas em relatório individual de cada disciplina, que é enviado ao professor e aos coordenadores dos respectivos cursos. Este relatório individual é sigiloso e, em consequência, não é distribuído à comunidade.”. (UnB, 2015, p. 24).
} 
administrativos e 694 estudantes. (UnB, 2016). O retorno, então, não é tão representativo; e, para o representante docente, entrevistado, isso se deve, em parte, ao fato de os questionários terem uma parte burocrática, a qual acaba desencadeando resistência, por exemplo, nos professores:

No processo como um todo tem uma parte burocrática que os professores, claro, vão ter uma resistência a isso. A gente já preenche nosso currículo, a gente mantem o currículo Lattes atualizado, a gente tem que fazer os processos de progressão funcional, então, quer dizer, a gente tem informação demais pra gente... tem um trabalho enorme pra gerar e, então, quando vem uma avaliação você de novo tem que apresentar seus documentos de novo. [...] Eu acho que os professores acham que é um pouco burocrático tudo. (DO, informação verbal).

Para o entrevistado em questão, boa parte das perguntas realizadas à categoria poderia ser extraída de bases de dados já existentes, como o currículo Lattes, por exemplo, do que subtende um questionário grande e com algumas questões desnecessárias. Há, portanto, uma burocracia envolvendo o processo e essa seria um dos fatores responsáveis pela falta de participação também do docente. Isso, contudo, não é algo constatado recentemente. Desde a década de 1980, referindo-se à primeira aplicação de questionários a professores da UnB, Belloni; Kipnis e Serafini (1980) já atestavam a baixa participação e reclamações análogas às atuais. Segundo os autores, aproximadamente $65 \%$ dos docentes, do universo total no qual um questionário foi aplicado, o responderam, "havendo, apenas em poucos casos, a explicitação dos motivos para o seu não-preenchimento. Em um dos casos, o argumento dado pelo professor foi de que "o questionário era demasiado extenso e complicado para ser respondido"”. (p. 23).

Desse modo, percebe-se que a autoavaliação realizada pelos docentes tem sido abordada no processo de autoavaliação da UnB, como apontou Bedritichuk (2015), "de modo raso e simbólico. As universidades brasileiras, de modo geral, já utilizam esse instrumento de consulta há mais tempo e, muitas vezes, de forma mais aprofundada e globalizada.”. (p. 53).

Faz-se necessário repensar constantemente os instrumentos avaliativos e, como previsto em pesquisas de mestrado da modalidade profissional, a autora em questão o fez. A mesma apresentou uma proposta de instrumento mais formativo para a categoria, o qual já vem sendo utilizado. O novo instrumento, específico ao docente, possui quatro blocos de questões. O primeiro com informações acerca do perfil do docente, o segundo com questões sobre infraestrutura física, o terceiro com questões sobre planejamento, avaliação, desenvolvimento e gestão institucional e o último com itens sobre políticas acadêmicas e 
gestão do corpo docente. A aceitabilidade, de acordo com a autora, foi muito positiva, especialmente porque os docentes viram nas questões uma forma de terem sua voz realmente ouvida - tamanha a insatisfação dos professores da UnB com relação à consulta à comunidade.

Apesar dessa importante iniciativa, percebe-se que, em suma, a participação, de modo geral, não é eficaz, precisando, pois, de mais revisões como a de Bedritichuk (2015) e também da continuidade da sensibilização da comunidade acadêmica, discutida no tópico anterior. Assim como concluiu Santos et. al (2013), tomando como base a problemática da baixa participação da comunidade acadêmica e especificamente dos discentes no IFBaiano, o sentimento de pertencimento a todas as fases da autoavaliação é necessário para que a CPA obtenha respostas da comunidade. A Comissão precisa, portanto, ouvir a comunidade, o que não se dá somente a partir de um único instrumento. Para o representante da Daes/Inep, entrevistado, o que

[...] se espera é que ela [a CPA] faça o reconhecimento do papel da instituição, dos objetivos da instituição, da missão, do seu compromisso social, e elaborem instrumentos que possam alcançar essas dimensões a partir dos diferentes olhares e atores da instituição. Então, é ver a percepção do estudante, ver a percepção dos docentes, dos funcionários técnico administrativos, da gestão, quer dizer, de todos aqueles que trabalham na comunidade acadêmica. Então, é importante que ela tenha diferentes instrumentos e às vezes é muito limitado o papel da CPA quando ela elabora um único questionário e não pensam algumas outras estratégias que podem aproximar a interlocução com os atores a partir do que ele pode vir a falar sobre o que lhe é oferecido na instituição, tanto das condições físicas, como das condições pedagógicas, da parte toda da ação educacional que se desenvolve. (IN, informação verbal).

O papel da CPA da UnB, com base nas colocações do representante da Daes/Inep e do que se expos até o momento, é, ainda, limitado. Como já dito no capítulo 1 desta dissertação, à CPA cabe, entre outras considerações, escutar os diferentes agentes da instituição, cada um nas suas especificidades. Não obstante, a CPA da UnB deve enfrentar desafios constantes para viabilizar isso. À Comissão recai, entre outras questões: (i) entender a autoavaliação, (ii) passar esse entendimento à comunidade acadêmica, sensibilizando-a da importância do processo, (iii) aumentar a participação da comunidade e, ainda, (iv) repensar os instrumentos, às vezes, até criando outros. Formular constantemente, como disse o entrevistado da Daes/Inep, estratégias que possam aproximar a interlocução com os diversos atores institucionais é um desafio a ser aperfeiçoado. 
A carga de trabalho da CPA é, contudo, na visão da autora desta pesquisa, muito pesada. Por isso, concorda-se com pesquisador da UFMG entrevistado quando esse diz que a gestão da instituição precisa "valorizar a avaliação, valorizar a autoavaliação. Isso é importante porque daí você tem uma unidade na ação política. A CPA sozinha não dá conta.”. (P3, informação verbal). Obviamente, seria muito simplista acreditar que o apoio maior da gestão resolveria todos os problemas e desafios de uma Comissão Própria de Avaliação, porém, é, sim, uma atitude importante a ser tomada no contexto da UnB quando se toma como perspectiva a visão deste colegiado. Como indica o representante técnico administrativo entrevistado, muitas vezes

[...] a consulta à comunidade evidencia as fragilidades e isso faz com que a própria gestão questione, um pouco, a metodologia; questione a fundamentação acadêmica daquilo que está sendo perguntado; se a gente tem ou não embasamento pra fazê-lo. (TE, informação verbal).

Assim, no lugar de um clima de troca e ajuda mútua entre gestão institucional e CPA, há desconfiança e questionamentos, o que em nada ajuda no processo autoavaliativo. A pesquisa de Rosas (2014), que dialoga consideravelmente com essa situação, demonstra que a falta de união entre CPA e gestão prejudica o alcance da autoavaliação. A autora buscou compreender como a autoavaliação na Universidade Federal da Paraíba (UFPB) influencia a construção dos valores e práticas que orientam a vida universitária. Para tal, realizou observação participativa nos Seminários de Autoavaliação da IES e entrevistou: membros das CPA, membros da Comissão Executiva de Avaliação Institucional (CEAI), diretores, vice diretores, coordenadores e vice coordenadores de cursos. Como conclusão, percebeu que os entrevistados não pertencentes à CPA têm receio de que a autoavaliação seja mais uma prática de controle aos seus trabalhos, o que fez com que a prática autoavaliativa não tenha sido ainda incorporada à rotina da UFPB.

A tão comentada cultura de avaliação formativa e, especificamente, de autoavaliação, sobre a qual se vem discutindo desde as considerações iniciais desta pesquisa, nã existe, pois, na Universidade Federal da Paraíba (ROSAS, 2014), assim como existe apenas parcialmente na Universidade de Brasília. Há, como comenta o pesquisador da UFSCar, em entrevista, grande dificuldade de as CPA serem reconhecidas por suas respectivas comunidades como um agente dessa avaliação. $\mathrm{Na} \mathrm{UnB}$, isso é perceptível: (i) na fase da preparação da autoavaliação, como visto no item anterior; (ii) na de desenvolvimento, comentada até então neste item; e, especialmente, (iii) na da consolidação do processo, onde, no caso em questão, a 
falta de uma parceria entre CPA, comunidade e gestão fica mais explícita. Junto a esse não reconhecimento da CPA, encontra-se o não reconhecimento da importância da autoavaliação, o descaso com o processo avaliativo e, ainda, a falta de confiança nele. Uma cultura de avaliação formativa e de autoavaliação, definitivamente, não é construída sob essas bases.

O desenvolvimento da autoavaliação no contexto da Universidade de Brasília, portanto, vem avançando na perspectiva formativa na medida em que já se revisou um dos instrumentos e se tenta, por meio da sensibilização da comunidade - comentada no item anterior -, contar mais com o apoio participativo dos docentes, discentes e técnicos administrativos da IES. Não obstante, é preciso avançar mais e constantemente. Os instrumentos destinados aos estudantes e aos técnicos administrativos também podem ser revistos e alguns novos podem ser criados, por exemplo. O necessário é se continuar aprimorando o processo.

A última fase da autoavaliação - a consolidação -, por sua vez, prevê: (i) a elaboração do relatório; (ii) a divulgação desse; e (iii) o balanço crítico do processo e resultados, sendo esse último um momento de reflexão que corroborará ações futuras por parte da CPA e da gestão da IES. Espera-se desse momento, segundo os representantes da Conaes e Daes/Inep entrevistados, que as CPA elaborem relatórios completos e consistentes. As IES devem atender à "elaboração de um relatório que seja não só uma descrição de informações, mas que para além da descrição ele promova a reflexão e ainda produza ações decorrentes da avaliação.”. (IN, informação verbal).

Contudo, no caso da UnB a comunidade acadêmica e a gestão ainda estão começando a conhecer a autoavaliação; a primeira participa ainda timidamente do processo autoavaliativo; e a segunda, como visto nas falas do representante técnico administrativo entrevistado, tem receio dos métodos utilizados no processo, chegando a questioná-los. Assim, seria inconsequente esperar, no contexto em questão, um formato ideal para essa fase.

De acordo com o entrevistado representante da Conaes, os relatórios de autoavaliação em um passado recente (há 10 anos ou menos) eram, de modo geral, basicamente vistos como cumprimento burocrático.

Esses relatórios eram simplesmente postados pra cumprir uma formalidade burocrática do Ministério. Essa era a tônica que existia. "Olha, nós temos até o dia 31 de março, é o que estabelece a Portaria, então nós temos que postar no sistema e-MEC. E o que que nós vamos fazer? Postar qualquer coisa". E era postado qualquer coisa, e tipo assim: "cumprimos um controle burocrático". (CO, informação verbal). 
Com o passar do tempo, para o mesmo entrevistado, os relatórios tornaram-se, salve exceções, cada vez mais completos e críticos. Contudo, como mostram Botelho e Sousa (2014) e Leite (2008), existem muitos relatórios pouco críticos, meramente expositivos e que não atendem todos os cinco eixos requeridos pelo Sinaes.

A respeito da UnB não se pode afirmar que em algum período se postava "qualquer coisa", como o representante da Conaes comentou fazendo referência a muitas IES. Além de não se ter apreciado nesta pesquisa os primeiros relatórios de autoavaliação, com base nos relatórios lidos e analisados - referentes a 2014 e 2015 - entende-se que ambos trazem muitas informações sobre a instituição. Esses contêm tanto considerações sobre todos os cinco eixos previstos (inclusive no relatório parcial do primeiro ano do novo ciclo - 2015), como relação com o PDI 2014-2017 da IES.

A missão da universidade, aludida em seu PDI, por exemplo, conforme registrado nas considerações iniciais da pesquisa, prevê que a instituição busque sempre inovar, e que se comprometa com a excelência acadêmica, científica e tecnológica, formando cidadãos conscientes de seu papel transformador. Além disso, a leitura analítica realizada dos relatórios de autoavaliação referentes a 2014 e 2015 permite constatar muitas descrições de políticas de assistência estudantil, de mobilidade acadêmica, de inovação na área tecnológica, pesquisa sobre evasão e retenção, pesquisa sobre o perfil do egresso ${ }^{69}$ etc.

Da mesma forma, no PDI, sobre o qual se comentou no capítulo 2, é registrada como visão de futuro da IES "estar entre as melhores universidades do Brasil, inserida internacionalmente" (UnB, 2014, p. 19) e, em consonância a isso, o relatório de 2015 traz, por exemplo, a notícia de que no ano em questão "pela primeira vez desde que o IGC é calculado, a UnB ficou entre as únicas onze universidades brasileiras que receberam a nota 5 , conceito máximo, de acordo com a avaliação do seu desempenho no ano de 2014.”. (UnB, 2016, p. 44). Acrescenta-se ainda a isso, segundo o mesmo relatório, que as posições da UnB em rankings nacionais e internacionais ${ }^{70}$ são sempre de destaque. Consequentemente, por mais questionável e intrigante que possa ser o destaque dado por um relatório de autoavaliação de uma instituição federal pública a rankings e à competição entre IES, o que a CPA está trazendo é o diálogo com o PDI da UnB, o qual incita a comparação da universidade às outras

\footnotetext{
${ }^{69} \mathrm{O}$ acompanhamento do egresso da UnB foi iniciativa retomada pela CPA em 2014 por meio de perceria com o Ministério do Trabalho e Emprego - MTE, o qual permitiu o acesso da Comissão aos dados identificados da Relação Anual de Informações Sociais - RAIS. (UnB, 2015).

${ }^{70}$ O relatório de autoavaliação da UnB referente ao ano de 2015 traz a posição da UnB nos seguintes rankings nacionais e internacionais: Ranking Universitário Folha (RUF); QS World University Rankings 2015/16; QS University Rankings América Latina 2015; QS World University Ranking BRIC; e Prêmio Melhores Universidades Guia do Estudante 2015.
} 
IES de mesma natureza. Cardoso e Dias Sobrinho (2014), afirmam que o Estado tem atitudes voltadas mais à competitividade e ao mercado do que, respectivamente, à solidariedade e à sociedade. Os organismos internacionais, por sua vez, propagavam uma qualidade reduzida a um percentual. Assim, admite-se como hipótese que a visão de futuro da UnB pode ser reflexo disso.

Não obstante, o fato de o conteúdo dos relatórios trazer os eixos previstos para a autoavaliação e o diálogo com o PDI 2014-2017 não faz, por si só, com que os relatórios não sejam caracterizados como burocráticos. A Nota Técnica, nº 065/2014, por exemplo, diz que a contemplação dos cinco eixos previstos pode ser feita no percurso do ciclo avaliativo, no caso, 2015-2017. O entrevistado da CPA, representante do corpo docente, disse que para o primeiro ano do ciclo "a gente escolheu dois eixos particulares, que foi o eixo 3 e o eixo 5." (DO, informação verbal). Contudo, no relatório de 2015 todos os cinco eixos, ainda que não em todas as dimensões, foram descritos. Infere-se disso, que os eixos 3 e 5, no relatório, são fruto de uma dedicação especial da CPA e os outros foram lá colocados, desnecessariamente, sem ter havido dedicação específica a eles, configurando uma caracterização burocrática, na concepção da autora desta pesquisa. E a forma como os relatórios são escritos também delata essa característica indesejável. Segundo pesquisador da USP, entrevistado,

[...] o esperado é que a Comissão consiga desenvolver um relatório que vá além do diagnóstico; que tenha passado da coleta de números e chegado a algum nível de análise desses números e mais coisa do que isso. Se coletaram dados a partir de questionários ou de grupos focais, que toda essa informação esteja sistematizada. (P2, informação verbal).

Nos relatórios da UnB analisados, no entanto, percebe-se uma dificuldade de se ir além do nível diagnóstico. A consulta à comunidade, por exemplo, realizada entre janeiro e março de 2016 e empreendida pela CPA, apontou, entre outras considerações, que os docentes, discentes e técnicos administrativos

[...] respondentes em sua maioria não souberam avaliar se as ações institucionais estão de acordo com o Plano de Desenvolvimento Institucional (PDI) da UnB (62\%) e se a Instituição faz uso dos resultados das avaliações externas e internas na gestão (43\%). A comunidade acadêmica, em sua maioria (52\%), discorda que é incentivada a participar da definição das políticas de gestão na Universidade. (UnB, 2016, p. 61).

Contudo, esses resultados não foram trabalhados no relatório a fim de se pensar um planejamento estratégico que ao fim do ciclo avaliativo (2015-2017) proporcionasse 
percentuais melhores. Além de a estatística levantada apontar a falta de interlocução entre gestão e comunidade acadêmica, a forma apenas descritiva como foram expostos mostra como não se ultrapassa o nível diagnóstico. Tendo, nesta pesquisa, somente a CPA como base, infere-se que no contexto em questão é como se já se escrevessem os relatórios sabendo que seus resultados serão usados conforme conveniência e não com base em recomendações dos membros da Comissão.

Um olhar crítico sob os relatórios enxerga uma CPA que, infelizmente, ainda não consegue se impor, na escrita e na prática, como agente coordenador da autoavaliação. A polidez $^{71}$ observável na escrita é, aparentemente, reflexo da realidade prática na qual o trabalho da Comissão está imerso. Com relação a isso, chamou atenção à autora desta pesquisa, parágrafo que se repete no relatório referente ao ano de 2014 e de 2015, aparecendo, respectivamente, na conclusão e na introdução desses, conforme transcrito a seguir:

A CPA reconhece que a elaboração deste trabalho é importante, mas não sintetiza e nem esgota o processo de autoavaliação que se pretende instituir na UnB. Trata-se de uma ação entre as muitas que devem ser realizadas para contribuir para um avanço seguro e consistente, que não dependa de voluntarismos, mas de ações institucionalizadas. (UnB, 2015, p. 186; UnB, 2016, p. 20).

Nesse simples, mas recorrente, trecho observa-se a CPA tomando o cuidado de não sobrepor a autoavaliação coordenada por ela aos processos estanques de autoavaliação que ocorrem na UnB, fazendo, inclusive, implicitamente, um elogio contido a todas as iniciativas.

Tão sutil como essa marca de polidez, também chamou a atenção o espaço maior dado aos "avanços" em determinada área, ao "protagonismo" da UnB em certo quesito etc., em comparação às poucas linhas reservadas às deficiências ou problemas institucionais. Não é que a universidade passe por poucas dificuldades. Há questões que urgem serem melhoradas e sobre as quais se tecem comentários nos relatórios, porém, a maior parte da escrita se dedica ao que no conjunto final dos eixos abordados converte-se para o leitor em uma espécie de propaganda da UnB.

O relatório referente a 2014 traz que a "elaboração dos relatórios de autoavaliação, baseada em pontos fortes e fracos, facilita o diálogo entre a avaliação institucional e o PDI, possibilitando a análise das recomendações da autoavaliação e gerando ações e estratégias

\footnotetext{
71 A palavra "polidez" não consta do dicionário ao qual já se recorreu algumas vezes no decorrer desta dissertação - o Houaiss - . De acordo com o Dicio - Dicionário online da língua portuguesa -, de acordo com a linguística, a palavra significa um discurso que demonstra cortesia, gentileza, através do uso de expressões que suavizam a autoridade imperativa do locutor. (DICIO, 2016).
} 
para a gestão institucional.”. (UnB, 2015, p. 73). No entanto, observa-se que a expressão "pontos fracos" é utilizada somente uma vez para listar deficiências da instituição. Em outras situações análogas, no mesmo relatório, utilizam-se termos de impacto bem mais ameno, como: "dificuldades", "principais barreiras" e "pontos que precisam ser melhorados" -.

Quando, por sua vez, são propostas, nos relatórios, algumas medidas a serem realizadas, raramente se pode assegurar que quem está propondo aquilo é necessariamente a CPA. Ou, explicitamente, são relatadas as metas de determinado decanato, por exemplo, para certo período, o que já isenta a Comissão da autoria da proposição, ou ocorrem duas situações linguísticas que acabam por indeterminar o sujeito. Observa-se, repetidas vezes no texto, ora construções com o verbo na terceira pessoa do plural (nós); ora verbos acompanhados do clítico "se" usado sintaticamente como "índice de indeterminação do sujeito", Tais utilizações deixam em suspenso a autoria da recomendação - se da CPA, se da gestão, se de determinada secretaria ou departamento etc..

A Comissão imprime sua marca em todo o relatório, mesmo porque é ela que o elabora, no entanto, passa a impressão de passividade. As partes dos relatórios em que se percebe maior posicionamento ativo da CPA são aquelas sobre os "resultados da consulta à comunidade acadêmica", ação que ela mesma empreende. Ainda assim, os dados apontados, sejam parciais ou finais, são muito descritivos; e por mais que, entre uma descrição e outra, apareça uma recomendação ou um "ponto fraco" de determinado setor da IES, esses momentos são diminutos quando comparados àqueles de descrições de pontos positivos ou relatos. Como aponta o entrevistado da Conaes, fazendo alusão aos relatórios de autoavaliação das instituições do país, apesar de os relatórios hoje serem mais consistentes e completos do que os do começo da implementação da política do Sinaes, "há muito campo para percorrer. Ainda há muito a ser melhorado". (CO, informação verbal).

Da mesma forma, na UnB, é evidente que os relatórios de autoavaliação de 2014 e de 2015, analisados, podem ser muito melhores que os do começo do processo autoavaliativo, por exemplo. O trabalho da CPA, como discutido na seção anterior e neste, está evoluindo e, logo, isso pode refletir nos relatórios. A equipe que forma a Comissão, por exemplo, apesar de bastante ocupada com outras funções ou carente de mais apoio, é muito bem preparada e vem empreendendo boas iniciativas, como a CPA itinerante, por exemplo. Mas, se valendo das

\footnotetext{
${ }^{72}$ Maiores informações sobre as estratégias existentes de indeterminação do sujeito na língua portuguesa podem ser encontradas na dissertação de Oliveira (2006). Em seu trabalho a autora analisou no português brasileiro e europeu, "à luz dos pressupostos da Sociolingüística [sic] Quantitativa e da Sociolingüística [sic] Paramétrica, algumas estratégias de indeterminação do sujeito: as formas pronominais nós e a gente, e o clítico se”. (p. 6).
} 
palavras do entrevistado imediatamente antes aludido, "ainda assim, há muito campo para percorrer". Na própria fala de entrevistado representante do corpo técnico da instituição identifica-se a percepção de que por mais completos que os relatórios sejam em termos de contemplação dos eixos, a polidez pode impedir que se aponte com precisão problemas e planos de soluções:

Olha, eu acredito que o que eles definem - e você não precisa abordar todos os eixos no mesmo ano -, a gente consegue abarcar na totalidade. Esse ano, por exemplo, a gente está optando por não trabalhar todos os eixos pra trabalhar um número reduzido e tentando abordar de forma mais qualitativa esses dados, mas eu percebo que muita das vezes o relatório ele não traz a tona todas as dificuldades que a gente nota, na produção mesmo no desenvolvimento do trabalho. A gente sabe que tem algumas iniciativas em curso que podem contribuir até para um relatório mais digno, que tenha um olhar mais real sobre a universidade, mas mesmo que a CPA seja um órgão independente, a entrega do relatório ao INEP ela acaba tendo uma cara mais institucional e isso é um pouco preocupante porque mesmo que nós realmente não somos subordinados à administração, mas é, por exemplo, aqui na universidade a gente nota uma, eu não sei se é só aqui, uma certa polidez. Então, eu não sei até que ponto há, e essa é uma experiência que eu estou vivendo agora, eu não sei dizer se de fato o relatório fechado vai ser transparente ou se ele vai, por exemplo, só apontar os esforços e o horizonte positivo. (TE, informação verbal).

Os relatórios analisados - 2014 e 2015 -, tais como estão escritos, carecem de um aspecto de fato mais avaliativo. É claro que se entende que a CPA é a coordenadora do processo e não a realizadora de todas as autoavaliações realizadas por outras equipes da instituição. Contudo, o excesso de descrições somado à falta de críticas, opiniões e deliberações próprias da Comissão dá ao relatório um aspecto de compilação. Assim, a preocupação do técnico administrativo entrevistado é bastante fundamentada e pertinente. Faz-se necessário cuidar para que na UnB não aconteça o que segundo representante da Daes/Inep, entrevistado, ocorre em muitas instituições do país. Para esse, algumas CPA "são muito vinculas à gestão e aí tende a ser um relatório no sentido do que a gestão quer e não um relatório que mostre as dificuldades e aquilo que pode ser superado, de ações estratégicas na instituição." (IN, informação verbal).

É preciso refletir sobre o impacto do trabalho da CPA na UnB. Para que serve o relatório? Para atender a determinação do Inep e promover a instituição entre as demais ou para subsidiar ações em prol da sua qualidade? Quando interpelados sobre para que vem servindo na prática o relatório de autoavaliação na UnB, os membros da Comissão Própria de Avaliação entrevistados tiveram respostas que transitaram entre o ideal e a realidade concreta. 
O representante da sociedade civil organizada, que no momento da entrevista apenas tinha participado de uma primeira reunião da CPA, concentrou-se no ideal, declarando que "toda autoavaliação que é feita em uma instituição ela precisa incidir nas aprendizagens dos estudantes". (SO, informação verbal). Da mesma forma, o representante discente afirmou que o relatório vem servindo para "tentar melhorar todas essas questões que a comunidade acadêmica precisa.”. (DI, informação verbal).

Já o docente declara que pelo menos para os chefes e coordenadores as informações podem ser muito interessantes, mas que especialmente pelo tamanho do relatório duvida que ele seja lido: "Para mim, por exemplo, quando eu entrei na CPA, que eu comecei a interagir com essas coisas, eu achei muito interessante ler aquilo tudo, mas eu duvido que muitas das pessoas leem. É um relatório muito grande.”. (DO, informação verbal). O representante do corpo técnico-administrativo, por sua vez, comenta que há no relatório de autoavaliação informações que não são encontradas em outros relatórios autoavaliativos da instituição, como o de gestão, produzido para o Tribunal de Contas da União (TCU). No entanto, para o entrevistado, o relatório produzido pela CPA é ainda pouco explorado:

O que eu vejo é que ainda esse relatório de autoavaliação é muito mais um cumprimento de rito do que um instrumento que possa favorecer a instituição a partir daquilo que está sendo publicado, conhecer como se dá o meu desempenho naquele ano, como que se dá o desempenho macro, por exemplo. (TE, informação verbal).

Dessa forma, se o relatório, ao que tudo indica, além de não ser lido, é "um cumprimento de rito", somente reafirma-se que apesar do mesmo conter os eixos exigidos e o diálogo com o PDI, por exemplo, converte-se, na prática, em cumprimento burocrático. Talvez não seja por acaso que os relatórios de autoavaliação referentes a 2015 e a 2014 declararem objetivos tão diferentes ao mesmo documento. No primeiro relatório parcial do novo ciclo avaliativo da UnB consta que: "este Relatório tem como objetivo contribuir para o conhecimento da Instituição e dar apoio à tomada de decisão.” (UnB, 2016, p. 19). Já o último relatório do ciclo anterior traz que o objetivo é "atender determinação do Sistema Nacional de Avaliação da Educação Superior (SINAES) que preconiza a apresentação de relatórios de autoavaliação institucional anuais das Instituições de Ensino [sic] Superior”. (UnB, 2015, p. 183). Fatalmente, caso não se faça nada para mudar, no final do novo ciclo, declaradamente ou não, se chegará à mesma conclusão: a de que o relatório servira, de fato, somente para prestar contas à política avaliativa. 
É sabido que ocorreram melhoras na infraestrutura física e segurança da UnB. Essas, segundo os membros docente, discente e técnico administrativo, são as medidas que podem ser citadas como fruto do trabalho da CPA. No entanto, relatórios que se prestam a avaliar a instituição em todos os seus aspectos podem subsidiar muito mais que algo pontual como isso. Tal como nas propostas avaliativas do Paru e do Geres, sobre as quais se falou no capítulo 2, a repercussão da autoavaliação não deveria ser reducionista. No Paru, planejava-se realizar uma espécie de pesquisa de avaliação sistêmica, a qual geraria diagnósticos que realmente subsidiariam posteriores ações por parte da gestão. (ROTHEN; BARREYRO, 2008). Já no Geres um dos objetivos da política era "estudar, propor e implementar mudanças no cotidiano das atividades acadêmicas do ensino, da pesquisa, da extensão e da gestão, contribuindo para a formulação de projetos pedagógicas e institucionais socialmente legitimados e relevantes." (BRASIL/MEC/SESu, 1993, p. 5). Para a autoavaliação, sob os moldes do Sinaes, as intenções não seriam as mesmas dessas políticas anteriores? Como um relatório cuja quantidade de páginas assemelha-se a pesquisas de mestrado ou até mesmo de doutorado e que analisa a instituição sob todos os principais aspectos, entre os quais pesquisa, ensino e extensão, não logram subsidiar mais mudanças positivas? Assim como no princípio do processo avaliativo da UnB, as repercussões práticas da autoavaliação são poucas. Como mostra a pesquisa de Lourenço (1998), sobre o uso dos resultados da avaliação do ensino de graduação da UnB, desenvolvida no período de 1987 a 1993,

[...] a passagem dos resultados da avaliação pelo CEPE ocorreu de forma burocrática, seja por falta de mecanismos, seja por falta de "vontade política" de utilizar esses resultados ou por mudança política/estratégica de avaliação da nova administração central. $O$ fato é que, no que se refere à administração central, não foram tomadas medidas para garantir a implementação dos resultados da avaliação. (p. 83-84).

Mesmo mais de duas décadas depois, o diálogo entre avaliação e tomadas de decisão continua sendo algo ainda não alcançado. A verdade é que nem é possível assegurar que as mudanças pontuais apontadas pelos entrevistados realmente tenham sido fruto dos resultados da autoavaliação. Apesar de a consulta à comunidade, realizada pela CPA, ter apontado a insatisfação com a infraestrutura (UnB, 2016), não se pode esquecer que, segundo os entrevistados, as metodologias empreendidas pela comissão sofrem muitas críticas por parte da gestão. Logo, o que pode ter desencadeado as mudanças foi, talvez, o desempenho insatisfatório de muitos cursos da UnB na dimensão 3 (Infraestrutura) da Avaliação de 
$\operatorname{Cursos}^{73}$. (UnB, 2015). A descrição contida no relatório de autoavaliação sobre a Avaliação de Cursos pode ter sido a real desencadeadora das mudanças e não necessariamente os dados provenientes da consulta à comunidade empreendida pela CPA ou de análises e sugestões apontadas pela Comissão.

Especulações a parte, o produto do processo autoavaliativo da UnB - o relatório de autoavaliação - pode e deve ter função formativa. Afinal, valendo-se da fala de entrevistado da Daes/Inep, “a gente entende que se não utilizado o relatório, de nada adianta terem sido feitos, né!”. (IN, informação verbal). No entanto, como já apontaram Botelho e Sousa (2014) e Zainko (2008), ainda não é um costume no país que os resultados das avaliações sejam amplamente divulgados dentro e fora das IES, subsidiem e surtam efeito na tomada de decisões da gestão. Deste ponto de vista, aos resultados faltam transparência e utilidade prática.

Muitas questões estão em jogo na passagem de uma função predominantemente burocrática à formativa; questões essas que, muitas vezes, ultrapassam os limites da CPA da UnB e da própria instituição. A descrença na autoavaliação é geral. Todos os quatro professores pesquisadores entrevistados, por exemplo, são enfáticos ao dizerem (em nove ocorrências) que os relatórios, em resumo, só atendem um cumprimento burocrático. Pesquisador da USP, também entrevistado, demonstra em sua fala que desde a instituição do Sinaes o mesmo já imaginava isso:

Então, na lei a autoavaliação era previsto para ser um passo importante em que houvesse participação das pessoas da instituição e fosse de alguma maneira o centro dentro dos procedimentos do Sinaes para a melhoria da qualidade. Ela deveria ser a referência dentro do Sinaes. Mas em um artigo de 2004 eu já alertava que isso não ia ser uma coisa de fácil desenvolvimento, que podia cair da burocratização e podia não passar mais de ser um relatório burocrático. (P2, informação verbal).

Da fala do pesquisador da UFSCar se infere que os relatórios não são elaborados para a comunidade acadêmica, que irá lê-los e tomar medidas em prol de melhorias na instituição a partir deles. Ao contrário, destina-se ao simples ato obrigatório de postar no sistema e-MEC, o que configura uma utilidade burocrática:

\footnotetext{
${ }^{73}$ Em 201435 cursos da UnB receberam avaliadores externos da Avaliação de Cursos. 9\% deles receberam nota inferior a $3(2,4$ a 2,9), 34\% obtiveram nota entre 3,3 a 3,9; a maioria (51\%) recebeu conceito 4 a 4,9 e apenas $6 \%$ obtiveram conceito 5 , o que, segundo o relatório de autoavaliação, reforça a necessidades de investimentos nas condições de ensino e na infraestrutura da Universidade. (UnB, 2015).
} 
$\mathrm{Na}$ verdade eu nunca fiz uma pesquisa sobre os relatórios, mas a percepção que eu tenho é que o relatório de avaliação institucional é um cumprimento burocrático, que a instituição preenche simplesmente pra postar. Postou, tá bom, né... [...] Normalmente os relatórios de autoavaliação eles não são feitos pra atender as demandas da comunidade acadêmica, mas sim para atender uma demanda de postar um relatório. (P1, informação verbal).

Já pesquisador da Unifesp, afirma ter participado de uma pesquisa encomendada pelo Inep, para a qual realizou análise de relatórios de autoavaliação de instituições públicas e privadas de todo o país. Para ele, a referida pesquisa lhe permitiu observar

[...] que a grande maioria [dos relatórios] considera parcialmente as dimensões e quando as considera traz informações muito pontuais com ausência de análise e reflexão. É como se você tivesse cumprindo uma tabela, um roteiro em que você traz as informações, mas você não constrói conhecimento sobre aqueles dados que são levantados. ( $\mathrm{P} 4$, informação verbal).

Finalmente, para o pesquisador da UFMG, na mesma linha de pensamento dos demais, o relatório serve sim para algo: "para visitas de avaliação de cursos, porque os avaliadores olham e fazem entrevista com a CPA. E só para isso.”. (P3, informação verbal).

Em suma, baseados, na maioria das vezes em pesquisas lidas ou na realidade de suas próprias instituições, todos os pesquisadores entrevistados consideram que os relatórios de autoavaliação são, tão somente, um instrumento burocrático. Como eles, muitos outros estudiosos da área de avaliação da educação superior podem chegar à mesma percepção. Entretanto, como afirmado pelos próprios entrevistados e comentado no item anterior, a academia tem uma dívida com essa temática. Geralmente, como disse o da USP, as pesquisas da área preferem ter o foco nos resultados esperados para o Enade. A pesquisa sobre autoavaliação, que poderia ajudar na valorização desse momento avaliativo e, consequentemente, no uso formativo dos relatórios, ainda é escassa no país.

Os entrevistados da Daes/Inep e da Conaes, por sua vez, demonstram de maneira muito positiva que, por cerca de dez anos, contou-se com uma autoavaliação vista com fim burocrático, cujos resultados não surtiam efeito nas IES. Mas que, a partir de 2014, agregando a autoavaliação ao processo regulatório da avaliação institucional externa "tudo está mudando.”. (CO, informação verbal).

O uso dos relatórios de autoavaliação preocupa o Inep, já que segundo entrevistado dessa autarquia, "após ter desenvolvido um relatório de autoavaliação e ter mostrado as dificuldades, muitas vezes as ações não são implementadas e não são entendidas como 
prioritárias dentro da gestão, então não dão sequência ao relatório.” (IN, informação verbal). Da mesma forma, também se pode dizer que este é um fator preocupante também para a Conaes, já que o entrevistado dessa, por sua vez, declara que "ao produzir o relatório dentro de uma instituição, esse processo, esse relatório, ele tem que ser apreciado, ele tem que ser levado para os colegiados superiores, mas não o é, ficando muitas vezes restrito à apreciação por meio do sistema e-MEC, do reitor ou do mantenedor, por exemplo". (CO, informação verbal). Atualmente, para os mesmos, com avaliadores externos atestando o que foi feito na IES a partir dos relatórios, esse panorama pode mudar:

Hoje os avaliadores, ao fazerem a avaliação institucional eles são orientados, ainda que de uma forma não muito profunda, mas que faça uma avaliação do relatório de autoavaliação. Pra quê? No sentido de verificar [se] aquele instrumento de avaliação ele tá sendo o quê? Um instrumento analítico, em que a instituição ela tá preocupada sim em se conhecer. (CO, informação verbal).

Contudo, é preciso refletir sobre a consequência dos anos de omissão do Inep, da Conaes e de demais órgãos responsáveis no que tange a apreciação dos relatórios das instituições. Por mais de uma década não houve retorno, por parte dos órgãos coordenadores do sistema, dos relatórios postados. Como disse o próprio representante da Conaes na entrevista concedida, "aquele relatório muitas vezes não era... assim, de 2.500 instituições sequer era olhado. Não era dado um feedback naquilo que está sendo postado.”. (CO, informação verbal).

A autora desta pesquisa compartilha da aposta dos entrevistados da Daes/Inep e da Conaes na incorporação dos relatórios de autoavaliação na avaliação externa. Como os entrevistados, a mesma também espera que, com isso, os relatórios tenham o retorno que merecem e que a autoavaliação seja mais valorizada. No entanto, salienta-se que, por mais compreensível que seja a falta de pessoal, recursos, tempo e ainda excesso de trabalho dos funcionários do Inep e dos membros da Conaes, a omissão desses por longo período de tempo pode ter influenciado negativamente o tipo de relatório produzido pelas CPA do país.

Múltiplas questões provenientes não só da CPA ou da UnB ou da instituição como um todo determinam a realidade em que se encontra o desenvolvimento e a consolidação de sua autoavaliação institucional. Não se pode julgar negativamente a Comissão Própria de Avaliação por sua polidez, por exemplo; ou a gestão institucional por sua aparente falta de apoio à CPA e falta de confiança nas metodologias por ela utilizada. $\mathrm{O}$ processo autoavaliativo da UnB faz parte de um todo complexo e maior: a realidade coadjuvante e 
eternamente "em aperfeiçoamento" da política de autoavaliação institucional, em nível do país.

O processo de autoavaliação descrito nos relatórios dessa universidade realmente não atende, na íntegra, as dimensões que a política do Sinaes prevê. O ideal é que se fizesse uma avaliação sistemática de todos os cinco eixos previstos, o que incluiria descrições, mas, sobretudo, críticas, planejamentos, metas, balanços do já alcançado e do a se alcançar. O que prevê o uso de questionários aplicados a uma parcela da institituição ou a toda ela, porém, mais que isso, a colaboração da comunidade acadêmica no processo avaliativo, opinando e incentivando sua viabilidade.

Ademais, na visão da CPA, os resultados da autoavaliação são, de fato, utilizados pela gestão da universidade de forma pontual - especificamente no que tange à infraestrutura e segurança. Quando alguém aprecia simplesmente o relatório de autoavaliação, as várias descrições e a ênfase nas ações acadêmico-administrativas da IES podem camuflar essa realidade, mas, intercalando os depoimentos colhidos e a observação da forma de escrita dos relatórios, enxerga-se mais claramente essa problemática.

Observa-se, a partir do olhar da CPA, dos relatórios de autoavaliação analisados, bem como das falas dos pesquisadores e dos representantes da Daes/Inep e Conaes - os quais corroboraram a compreensão do processo autoavaliativo da UnB - que os relatórios dessa institituição, assim como os de muitas outras, deveriam ter, sobretudo, função formativa, mas encerram-se burocráticos. Sem ser possível e correto apontar culpados; sem atribuir a responsabilidade disso à falta de pesquisas, à omissão do Inep e da Conaes no retorno dos relatórios, ou à própria Universidade de Brasília, na figura dos agentes $\mathrm{X}$ ou $\mathrm{Y}$, o que é certo e indiscutível é que o processo autoavaliativo tem muito que melhorar para que venha tornar-se verdadeiramente formativo.

Os relatórios não precisam servir apenas para tomadas de decisões pontuais, postagem no sistema e-MEC ou para promover os vários logros de uma instituição. Ainda que, por exemplo, como visto no capítulo 1, o mercado influencie todas as IES - sejam públicas ou privadas -, já que é ele que vai empregar boa parte dos egressos das instituições, não se faz necessário impressioná-lo. Muito mais construtivo que limitar o relatório a essa e às outras funções imediatamente antes citadas, é agregar às descrições: críticas e sugestões da própria CPA, inclusive com planos de metas, com prazos etc. Afinal, a Comissão necessita empoderar-se e tomar posse das funções que tem direito e dever de cumprir. 


\subsection{SÍNTESE PARCIAL}

As três fases que compõem a autoavaliação de acordo com as diretrizes do Sistema Nacional de Avaliação da Educação Superior - preparação, desenvolvimento e consolidação nem sempre acontecem como idealizado. A trajetória de implementação do Sinaes delineou um protagonismo apenas fictício para a avaliação institucional e, especificamente, para a autoavaliação. Como afirma Ball (2013), políticas

[...] are contested, interpreted and enacted in a variety of arenas of practice and the rhetorics, texts and meanings of policy makes do not away translate directly and obviously into institutional practices. They are inflected, mediated, resisted and misunderstood, or in some cases simply prove unworkable $^{74}$. (BALL, 2013, p. 9).

No contexto da política do Sinaes a síntese do referido autor se aplica perfeitamente. A tradução entre o elaborado para a autoavaliação e o praticado em muitas instituições do país não é direta, senão repleta de embates. O Sinaes, como discutido no capítulo 1, prevê equilíbrio entre seus três pilares e entre sua função reguladora e formativa (RIBEIRO, 2012) a fim de se instituir uma cultura de avaliação formativa. No entanto, com base na focalização em apenas um de seus pilares - a autoavaliação - fica perceptível que essa equidade é inexistente. Justamente no que tange à avaliação que seria a principal do sistema, percebe-se que novos contornos são adquiridos - influenciados por contradições existentes nas próprias IES, no caso, a UnB, e na historicidade nacional dessa avaliação. Na preparação, desenvolvimento e consolidação da autoavaliação na UnB identificaram-se inconsistências e dificuldades que comprometem esse processo avaliativo. Mostradas neste capítulo, elas são ilustradas sinteticamente no quadro a seguir:

\footnotetext{
${ }^{74}$ [...] são contestadas, interpretadas e promulgadas numa variedade de áreas e de práticas e retóricas, textos e significados dos que as elaboraram e que nem sempre se traduzem direta e obviamente em práticas institucionais. Elas são impostas, mediadas, resistidas, incompreendidas ou, em alguns casos, simplesmente comprovam-se impraticáveis. (Tradução de Silva; Martins e Abdala, 2014, p. 42).
} 
Quadro 10: Síntese das problemáticas identificadas na prática da autoavaliação da UnB relativas aos anos de 2014 e 2015.

Preparação
-Rotatividade de membros
(sobrecarga de trabalho e
falta de incentivo);
-Falta de estrutura;
- Falta de autonomia;
- Falta de foco durante as
reuniões da CPA;
- Desconhecimento quanto à
autoavaliação. Tanto os
membros da CPA, quando
entram nessa, como a
comunidade acadêmica a
desconhece. A tarefa da
sensibilização é
duplamente desafiadora;
-Descrença da comunidade;
- Os outros campi que fazem
parte da UnB não são
devidamente
sensibilizados.

Desenvolvimento
•Os instrumentos de
consulta à comunidade
aplicados pela CPA não
obtém uma quantidade
significativa de respostas.
-Os possíveis respondentes
não têm interesse em
colaborar e não se veem
representados no
instrumento, já que o
mesmo não individualiza,
em termos de questões, os
diversos grupos existentes
na IES.
-A CPA tem sua
metodologia
fundamentação acadêmica
constantemente
questionadas.
•Os outros campi que fazem
parte da UnB não são
devidamente auscultados.

Consolidação
•Os relatórios são reduzidos
à funcionalidade
burocrática de se postar
algo no sistema e-MEC;
-Os relatórios apresentam
uma linguagem polida, são
pouco críticos,
excessivamente
descritivos,
informativos no que tange
a metas precisas e com
mais destaques a avanços
do que a deficiências;
•Há dificuldade de se
assegurar que fora a CPA a
autora das proposições dos
relatórios;
- Ações conscientes por
parte da gestão, baseadas
nos resultados apontados
no relatório, se dão apenas
pontualmente.

Fonte: Elaboração própria.

As falas dos entrevistados - representante da Daes/Inep, da Conaes, dos pesquisadores da área de avaliação da educação superior e da CPA da UnB -, quando contrapostas, demonstraram, em nível macro e micro, o contexto no qual vem avançando a autoavaliação na UnB e em outras IES, o qual é explanado no quadro 10. Este capítulo, contudo, não apontou nenhum desses interlocutores como culpados dos tropeços e das dificuldades da caminhada autoavaliativa. De fato, metaforicamente, cogitou-se a possibilidade de um crime contra a autoavaliação, como dito no tópico anterior. No entanto, encaminhando-se para as considerações finais desta dissertação, já se torna perceptível que as ações e omissões dos entrevistados compõem apenas parte do movimento histórico que culminou em uma prática avaliativa ainda urgente de reparos.

Representativos de um recorte temporal de dois anos e de grupos maiores de pessoas, os entrevistados têm apenas uma parcela de contribuição no modus operandi da prática avaliativa. Não obstante, todos eles e, sobretudo, os membros da CPA são vítimas, pois não 
ter uma cultura de avaliação formativa, e de autoavaliação, instituída dá espaço, em certa medida, a uma situação de subordinação a avaliações do tipo controladoras.

A prática da autoavaliação não é determinada por uma Lei, por uma Portaria ou por Nota Técnica, especificamente. Todas as medidas legais implementadas, ainda que tardiamente, delineiam os rumos para a prática autoavaliativa, mas não asseguram a viabilidade desses. As atitudes da CPA e de seus colaboradores técnicos; da comunidade acadêmica, representada por docentes, discentes e técnicos administrativos; da equipe de gestão da instituição; dos pesquisadores que se debruçam sobre a temática; do Inep, da Conaes e demais responsáveis pela política são decisivas na implementação prática da autoavaliação. Sendo assim, atenção especial é preciso ser dada, pelos mesmos, ao processo desde a fase da preparação até à da consolidação.

Este capítulo, que objetivou analisar, com base em Bardin (2004), a prática da autoavaliação, encontrou, nas temáticas que se mostraram frequentes nas declarações dos entrevistados, as problemáticas e desafios pungentes desse momento avaliativo. A autoavaliação, apesar de estar inserida em um ciclo avaliativo que tem começo, meio e fim (relatório parcial 1, relatório parcial 2 e relatório final), não deve encerrar-se no cumprimento legal e simplesmente burocrático de postagem de um relatório no Sistema e-MEC. Tudo o que é realizado em nome da autoavaliação ou para a viabilidade dela durante cada ciclo são pequenas marcas da construção de algo maior, que espera-se ser a qualidade educacional.

No contexto da Universidade de Brasília, no entanto, o percurso precisa ser totalmente assistido para que os resultados apontados no relatório de autoavaliação subsidiem, no futuro, de fato, múltiplas ações em prol da qualidade. Caso o tamanho do relatório e a quantidade de descrições colocadas nele fossem sinônimos de melhorias práticas, não seria preciso preocupar-se com o processo autoavaliativo da UnB. No entanto, essas características não são positivas quando desacompanhadas de mais críticas, metas, prazos, maior participação da comunidade acadêmica, bem como empoderadamento visível da CPA.

Os membros da Comissão Própria de Avaliação da UnB vivem o desafio constante de: ressignificarem a proposta de avaliação do Sinaes - compreendendo-a e adequando-a a realidade local -, assim como de sensibilizarem a comunidade acadêmica e a gestão sobre a importância desse processo - explicando-lhes o que ele é e para que serve. Ademais, precisam lidar com condições adversas de estrutura física e humana que facilite seu trabalho, além, é claro, da falta de tempo para as atividades inerentes à função de membros da CPA. Ainda muito polida, a Comissão vê-se, às vezes, em uma situação de ter que prestar conta de seu trabalho, respondendo a questionamentos sobre metodologia utilizada, por exemplo. Em 
suma, seus membros demonstram carecer de apoio e voto de confiança para lograr se imporem, de fato, como coordenadores do processo.

A despeito de todos os senões, reúnem-se em média uma vez ao mês, acompanham visitas de avaliadores externos, aplicam instrumentos de consulta à comunidade, promovem Fórum anual sobre a autoavaliação e empreendem com a iniciativa da "CPA itinerante", por exemplo. Pelo pioneirismo da UnB na autoavaliação era possível se pensar que essas e outras possíveis ações poderiam já fazer parte de sua rotina, no entanto, não o são. A Comissão Própria de Autoavaliação, formada por profissionais envolvidos com a área de gestão, vem fazendo a sua parte para o que pode vir a ser, um dia, uma cultura de avaliação formativa e, especificamente, de autoavaliação.

A autoavaliação, por muitos anos, como visto neste capítulo, não foi assistida pelo Inep, Conaes e demais responsáveis como o esperado. Os próprios agentes entrevistados dessas instâncias comentaram sobre as dificuldades em fazê-lo e também sobre o fato de sequer ter sido possível dar feedbacks dos relatórios de autoavaliação às IES. Além disso, sob a perspectiva dos pesquisadores entrevistados, a autoavaliação não parece ser o maior foco de interesse das pesquisas nas áreas de avaliação da educação superior do país; e os mesmos demonstraram, muitas vezes, terem descrença com relação a esse processo avaliativo. Mesmo assim, existem ações recentes do Inep nas quais se deposita bastante confiança, como as empreendidas pelo documento "Instrumento de avaliação institucional externa" (BRASIL/Inep/Daes, 2014), pela Portaria $\mathrm{n}^{\circ}$ 92, de 31 de janeiro de 2014 (BRAIL/MEC, 2014) e pela Nota Técnica do Inep/Daes/Conaes $n^{\circ}$ 065, de 09 de outubro de 2014 (BRASIL/Inep/Conaes, 2014). E existem pesquisas, como esta, cujo foco é a autoavaliação institucional. Como sintetiza a ilustração 5, a seguir, tal como uma seta que aponta rumo ao idealizado para a autoavaliação - cultura de avaliação formativa e de autoavaliação -, essas e outras ações devem continuar sendo empreendidas, aperfeiçoadas e expandidas. 
Ilustração 5: Ações realizadas pelos grupos representativos da pesquisa em 2014 e 2015 e projetadas para os mesmos em prol do alcance da cultura de avaliação formativa e de autoavaliação

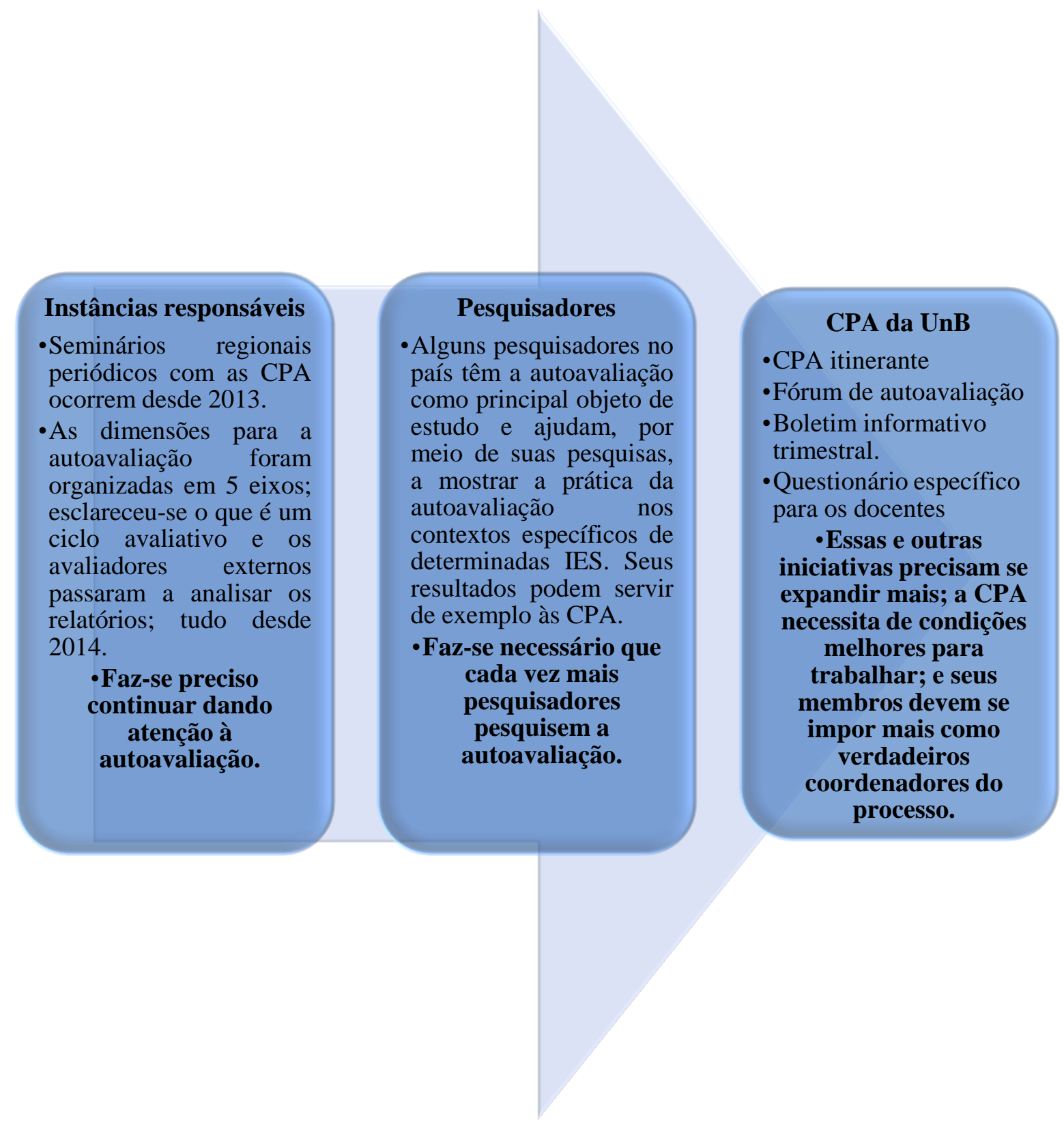

Fonte: Elaboração própria.

Como fica claro com a ilustração 5, não somente de omissão e descrença se forma o contexto da autoavaliação no Brasil. Assim como na CPA da UnB, em órgãos reguladores e em pesquisadores se enxerga também persistência. Com essas atitudes, muitos avanços são, sim, possíveis. 


\section{CONSIDERAÇÕES FINAIS}

A presente pesquisa teve como objetivo geral compreender em que medida o previsto pelo Sistema Nacional de Avaliação da Educação Superior para a autoavaliação é ressignificado na prática da Universidade de Brasília. Esta instituição de educação superior foi escolhida por ser pioneira no processo de autoavaliação no Brasil, tendo, inclusive, servido de referência para a construção da política avaliativa em vigência. Contudo, a despeito de qualquer expectativa que se pudesse criar com base no destaque nacional da IES nesse quesito, os resultados mostram que a UnB, assim como outras instituições, tem muitos desafios pela frente no que tange a fomentar uma cultura de avaliação formativa e, especificamente, de autoavaliação.

Apesar de já haver no Brasil uma cultura de avaliação - vis-à-vis essa prática estar presente nas políticas da educação superior desde a década de 1980 -, uma cultura de avaliação formativa encontra-se mais na teoria do que na prática. Mesmo a realidade educacional sendo complexa, dinâmica, polissêmica e constituída de relações humanas de interação, por muitos anos, prevaleceram, a exemplo do Exame Nacional de Cursos, avaliações incompatíveis a isso, já que controladoras. Uma avaliação formativa tem função ético-política (DIAS SOBRINHO, 2004) e cunho emancipatório (OLIVEIRA; FONSECA; AMARAL, 2006). Pretende promover a autonomia da comunidade acadêmica, gerar decisões baseadas na participação democrática, melhorar a IES nos pontos que a própria comunidade aponta como necessários e formar cidadãos com competências que extrapolam as requeridas pelo mercado, tais como as éticas, científicas e políticas. Qualquer ato regulatório do Estado sobre a educação superior pode e deve valer-se desse tipo de avaliação, contudo, nem mesmo o Sinaes, que revela, em sua base legal, uma proposta formativa emancipatória, vem logrando fazê-lo.

Sob o contexto de um Estado que, historicamente, seguindo tendências mundiais e orientações de organismos internacionais, não se preocupa com a avaliação formativa, com a autoavaliação ou com dar voz às instituições, o Sinaes se adapta à cultura regulatória, se desenvolve e se modifica. No contexto dessa política avaliativa, foi possível identificar, no decorrer do estudo, três momentos que determinam seus contornos: (i) uma proposta formativa; (ii) um retorno a práticas controladoras, com a supervalorização do Enade; e (iii) um momento atual - híbrido - em que mantem-se índices, mas passa-se a assistir e valorizar mais a autoavaliação. Os retornos a práticas passadas e o hibridismo de alguns momentos de mudança de rumos eram esperados e se concretizaram, portanto, nesses três momentos. 
Como adverte Marx (1983), em uma situação específica no prefácio do livro “O Capital", "todo começo é difícil - isso vale para qualquer ciência." (p. 11). Da mesma forma, pode-se interpretar que a compreensão e aceitabilidade da proposta do Sinaes, bem como das posteriores modificações desse, não seria algo fácil nem aos que o coordena, nem aos que o vivenciam na prática. O Sinaes deriva de políticas avaliativas anteriores antagônicas, imprimindo práticas que ora se aproximam do passado controlador rechaçado, ora ressignificam o passado formativo, antes subjugado. Ainda que se compreenda, contudo, que imprimir uma cultura de avaliação formativa é tarefa árdua e demorada, não é mais admissível que, passado mais de uma década da instituição do Sinaes, a protagonista do sistema avaliativo - a autoavaliação - continue, na prática, sendo coadjuvante. Símbolo representativo do que seria uma avaliação formativa ideal e também, no contexto do sistema, principal - a autoavaliação ainda está dando seus primeiros passos, tal como uma criança.

Entre as contradições que envolvem o Sinaes e que foram nesta pesquisa trazidas à tona, a (re)organização do sistema ganha destaque. Composto originalmente por três pilares que deveriam completar-se - Avaliação dos Cursos de Graduação, Avaliação do Desempenho dos Estudantes e Avaliação das Instituições da Educação Superior -, o Sinaes continua garantindo a existência de todos esses, mas sem a essência colaborativa prevista. Quem se lembra da autoavaliação ou da avaliação de cursos quando a referência maior para fins regulatórios é o Enade? Em uma cultura avaliativa em que números, rankings e scores sempre tiveram mais valor, incrementar o peso da avaliação do estudante sem assistir devidamente os outros pilares é esgueirar-se da difícil missão de fomentar uma cultura de avaliação formativa.

Neste contexto, mesmo tendo em mente que os atores sociais das instituições de educação superior podem ter atitudes voltadas a esquivarem-se da cultura de resultados (GARCIA; ESPINDOLA; SORDI, 2011), a tese que orientou este estudo não foi idealista ao ponto de idealizar isso para o contexto da IES pesquisada. Ainda que a autoavaliação tenha sido prevista - já que inserida na avaliação institucional - como o instrumento principal da política do Sinaes, tomou-se como tese que ela ainda precisa avançar. Devido às marcas da subsunção do passado e do presente a avaliações controladoras, foi mais plausível crer que a autoavaliação não lograria exercer seu papel formativo intencional; e, infelizmente, na realidade analisada nesta pesquisa - a da $\mathrm{UnB}$-, isso veio a ser comprovado.

Cuidado especial ao tema da autoavaliação foi preciso, vale ressaltar, ser adotado neste trabalho. Em respeito à complexidade da temática da avaliação - repleta de embates, avanços e retrocessos -, e também à responsabilidade de ter como parte empírica uma instituição como a UnB - universidade e percussora da avaliação institucional no país -, imprimir um olhar 
dialético foi a opção mais adequada, na visão da pesquisadora. Não seria possível entender a prática da autoavaliação na Universidade de Brasília sem levar em conta o aprofundamento na realidade empírica. Perscrutar vozes de vários sujeitos; leis, notas técnicas, portarias, relatórios e planos; e ainda dissertações, teses e artigos, os quais, às vezes, traziam à tona o que nunca se deseja enxergar, era um processo necessário; e mais viável sob a perspectiva dialética.

A começar pela escolha dos agentes entrevistados, o objetivo sempre foi levar em consideração o olhar dialético, afinal seria insuficiente focalizar a visão da Comissão Própria de Avaliação da UnB e não levar em conta perspectivas de outros responsáveis e interessados pela autoavaliação. Assim, além de quatro representantes da CPA dessa IES - um de cada segmento (docente, discente, técnico administrativo e sociedade civil organizada) -, foram auscutados quatro pesquisadores da área de avaliação da educação superior e ainda um representante da Conaes e um da Daes/Inep.

A adoção de categorias metodológicas e de conteúdo, por sua vez, - as primeiras intrínsecas à escolha do uso do olhar dialético -, contribuiu, consideravelmente, à impressão desse olhar. No que se refere às categorias metodológicas, a contradição - própria do movimento da história -, emergiu nas intenções raramente implementadas. A contradição fezse presente na observância de um projeto de instituição de educação superior formadora de cidadãos críticos; e na prática da formação de funcionários para o mercado de trabalho. $\mathrm{Na}$ necessidade de complementariedade do momento de regulação e de avaliação formativa; e na realidade de sobreposição da regulação à avaliação. Na qualidade da educação confundida com scores e rankings; assim como no maior apoio dado ao ENC do que ao Paiub. E em um duradouro sistema de avaliação, em relação ao tempo de vigência dos antecessores, mas que, mesmo com o tempo, ainda retorna, volta e meia, às práticas que sua própria intencionalidade nega. Enfim, a categoria da contradição está em tudo, até porque é com ela que a história se avança.

A mediação - categoria metodológica também utilizada no estudo -, apareceu nas relações entre pares que acabam por influenciar o objeto. Ao fim do trabalho percebe-se que o modelo capitalista de Estado, as avaliações que antecederam o Sinaes, as mudanças empreendidas nessa política avaliativa, etc. são questões que se relacionam entre si e com o objeto de pesquisa - a autoavaliação. Da mesma forma, percebe-se que docentes pesquisadores, representante da Daes/Inep, representante da Conaes e membros de segmentos distintos da CPA da UnB têm vários posicionamentos em comum e em divergência; e contribuem, ao mesmo tempo, de forma bastante significativa com a prática da autoavaliação. 
É que todas as relações aparentemente estanques, na verdade, se completam quando mediadas.

A totalidade, finalmente, ainda que não tenha sido aprofundada nesta dissertação, é a categoria na qual se insere a contradição e a mediação. Como diz Gadotti (1984), "a natureza se apresenta como um todo coerente onde objetos e fenômenos são ligados entre si, condicionando-se reciprocamente". (p. 24). E neste trabalho, desde as considerações iniciais até o capítulo 3, toma-se a história como parâmetro e a autoavaliação ora aparece em uma perspectiva macro, ora micro - fazendo parte do todo ou o sendo.

As categorias de conteúdo, por sua vez, igualmente contribuintes do olhar dialético, foram regulação, avaliação formativa, qualidade da educação superior e relatórios de autoavaliação reduzidos ao cumprimento burocrático. Essa última - única selecionada à posteriori -, o foi, pois emergiu, lamentavelmente, da fala de todos os dez agentes entrevistados para esta pesquisa. Na essência do objeto encontra-se a finalidade burocrática; e, muito provavelmente, supõe-se que os capítulos levaram o leitor a não se assustar com esse achado de pesquisa.

Estruturados de modo a propiciar a mediação necessária entre a política nacional e o contexto específico da Universidade de Brasília, a estruturação dos capítulos teve como propósito conduzir o leitor à percepção das relações contraditórias que envolvem o objeto da pesquisa. No primeiro capítulo foi discutido o desafio de se fomentar qualidade por meio de avaliações diante de concepções divergentes de finalidade educacional; tipo avaliativo e aspectos da qualidade. No segundo capítulo foram problematizadas as idas e vindas das avaliações formativa e controladora e como que a implementação do Sinaes carrega as marcas de ambas. No terceiro capítulo enfocou-se no contexto de omissão, descrença e, ao mesmo tempo, persistência, no qual a autoavaliação é posta em prática. Em todos esses três capítulos o contexto nacional e o local foram mediados; e, de forma transversal, algumas contradições emergentes destacam-se em meio às categorias de conteúdo, igualmente contempladas.

Sob o ponto de vista do marco legal, percebeu-se uma contradição já na intencionalidade das instituições brasileiras de educação superior. Com vistas à expansão do setor educacional, em nível de graduação, para que se subsidiasse mão de obra ao mercado, a Constituição Federal de 1988 (BRASIL, 1988) e a Lei de Diretrizes e Bases da Educação Nacional de 1996 (BRASIL, 1996) deram abertura à expansão desenfreada do setor privado. Especialmente a partir dessa lei, por exemplo, foi possibilitada a segmentação institucional, diferenciando universidades, centro universitários, faculdades etc.; e as menores exigências aos dois últimos tipos de IES atraiu a iniciativa privada, a qual, mais do que nunca, voltou-se, 
especificamente, ao lucro. Assim, no lugar de uma intencionalidade voltada à emancipação do sujeito, à formação de cidadãos críticos, conscientes e com valores e habilidades que extrapolam as exigências do mercado, propagou-se, sob o aval do Estado, uma intencionalidade lucrativa, que, geralmente, não dava espaço a uma formação abrangente.

Quando o mais importante é o lucro, metas como a 12 do Plano Nacional de Educação 2014-2024 para a expansão do setor tornam-se igualmente contraditórias. Essa, prevê "elevar a taxa bruta de matrícula na Educação Superior para 50\% e a taxa líquida para 33\% da população de 18 a 24 anos, assegurada a qualidade da oferta e expansão para, pelo menos, $40 \%$ das novas matrículas, no segmento público" (BRASIL, 2014, meta 12, grifo nosso). A expansão é estatisticamente possível, não obstante, que qualidade seria essa? Diante da diferenciação das IES em classificações acadêmico-administrativas bastante distintas; da força da regulação sob as IES; e da finalidade lucrativa historicamente preponderante o termo "qualidade" somente poderia ser mesmo polissêmico - como bem contextualizaram Gadotti, 2013; Dourado e Oliveira, 2009; Sousa, 2009; e Burlamaqui, 2008. As IES privadas e mesmo as públicas são influenciadas por essas questões e, em especial, pela finalidade lucrativa. Para as primeiras é preponderante a necessidade de destaque e de classificações como "melhor que a IES X"; e para as segundas, que não se desenvolvem em um mundo à parte, a necessidade de se promoverem também vem tornando-se algo comum. No relatório de autoavaliação da UnB, por exemplo, chama atenção o destaque dado ao posicionamento da IES em rankings e ao Índice Geral de Cursos alcançado.

Outra contradição observada, a qual está imbrincada às anteriores, envolve o próprio histórico das políticas de avaliação da educação superior do país. O Programa de Avaliação Institucional das Universidades Brasileiras tinha base formativa, porém, não foi instituído por iniciativa do governo. Esse último, permitiu a existência do Paiub por certo tempo, mas a iniciativa foi das universidades públicas. Assim, na primeira oportunidade de se instituir uma avaliação mais condizente ao gosto do mercado pela competição, a "substituição" foi feita. O Exame Nacional de Cursos, que subsidiava rankings, comparações entre IES e nenhum empoderamento dos sujeitos das instituições ou reflexões profundas e críticas foi instituído no governo Fernando Henrique Cardoso e ganhou a aceitação popular imediatamente. As comunidades acadêmicas, ao não conhecerem profundamente uma avaliação formativa, por sua vez, abraçam mais facilmente a controladora, ainda que a primeira seja muito mais abrangente e benéfica.

Em suma, com base nas características das legislações instituídas para a educação superior e, também, no próprio ENC, pode-se dizer que o Estado nunca deu sinais de que sob 
o seu aval se instituiria uma avaliação formativa. No entanto, no governo de Luís Inácio Lula da Silva tentou-se, aparentemente, não agradar somente o mercado. Mesmo com um cenário de continuidade da expansão da educação superior privada na forma de incorporação de IES menores por grupos institucionais maiores ou ainda de holdings, a população brasileira foi apresentada a uma política avaliativa formativa - o Sinaes. A proposta era admirável. Por um momento até cogitou-se a não realização de avaliação do estudante a fim de se diferenciar ao máximo do ENC; no entanto, decidiu-se fazê-la, mas de forma bastante diferenciada. (MENEGHEL, 2015). Além disso, pela primeira vez, a autoavaliação não só seria uma prática promovida pelo Estado como um dos principais elementos da política. Com o decorrer do tempo, foi-se, contudo, incrementando-se a avaliação do estudante a partir do aparecimento dos índices sob seu escopo; e passou-se a se utilizar como referência para fins regulatórios apenas o Enade (GRIBOSKI, 2014). A autoavaliação estava nas pautas das discussões dos órgãos responsáveis, mas os relatórios provenientes do processo sequer eram apreciados.

Uma década após a instituição do Sinaes resolveu-se fazer algo pela autoavaliação, lembrando-se, assim, que a proposta da política avaliativa ainda era formativa. Foram realizados seminários regionais periódicos com as Comissões Próprias de Avaliação de todo o país a partir de 2013. As dimensões da avaliação institucional foram organizadas em cinco eixos. (BRASIL/MEC, 2014); esclareceu-se o que era um ciclo avaliativo e diferenciou-se relatório parcial e integral (BRASIL/Inep/Conaes, 2014). Ademais, finalmente encontrou-se um leitor oficial para os relatórios de autoavaliação, já que os avaliadores da avaliação institucional externa deveriam ter acesso ao relatório e analisá-lo antes da visita in loco, pontuando-os em uma escala de 1 a 5. (BRASIL/Inep/Daes, 2014, p. 5). Assim, tão contraditório como o elemento principal de uma política só ser assistido passado uma década, é o fato de se ter que incorporá-lo à avaliação institucional externa. Com isso, esperou-se resolver duas questões: a omissão de anos dos órgãos responsáveis, os quais tampouco tinham condições suficientes em termo de pessoal para analisar relatórios (MENEGHEL, 2015); como a falta de uma cultura de avaliação formativa e autoavaliativa que fizesse as IES se autoavaliarem crítico e profundamente sem que fossem reguladas para tal.

O impacto dessas ações se enchergará, talvez, em uma década. Por ora, vê-se, no entanto, tomando como exemplo a UnB, que há instituições que vêm esforçando-se para melhorar seu processo autoavaliativo. Segundo membro da CPA, entrevistado, há cerca de dois anos podia-se dizer que não se tinha uma CPA atuante.

Era uma CPA com muitas dificuldades de se firmar, então, por exemplo, é muito comum os avaliadores se perguntarem como a CPA atua [...] e aí, se a 
gente for considerar que essa é a voz do Inep, então a gente sabe que é essa a grande diferença. Há alguns anos não se tinha nada a dizer enquanto CPA; e à medida que se foi trabalhando, fazendo pesquisa de egressos e que foi consolidando ações importantes, como o Fórum de avaliação, consulta a comunidade, é que [...] o Inep passou a ter uma outra percepção, já que nós somos também avaliados. (TE, informação verbal).

Apesar da atuação maior da CPA da UnB no ano de 2016, não se pode ainda, segundo o mesmo entrevistado, comemorar; e isso ficou claro no capítulo três desta dissertação. A partir da autoavaliação previa-se a produção de conhecimentos sobre a realidade da IES; a melhora da qualidade educativa; o aumento da consciência pedagógica e a capacidade profissional do corpo docente e técnico-administrativo; o fortalecimento das relações de cooperação entre os diversos atores institucionais; o vínculo com a comunidade; e a prestação de contas à sociedade, por exemplo. (BRASIL/Inep, 2011). Todos esses itens, que seriam extremamente benéficos a qualquer instituição, estão ainda sendo construídos e implementados na UnB.

O Sinaes prevê que a autoavaliação se dê em três fases complementares e indispensáveis: (i) a preparação; (ii) o desenvolvimento; e (iii) a consolidação. A realidade prática desse processo avaliativo na UnB, no entanto, mostra que as duas primeiras ocorrem com muitas precariedades e que a última, além disso, nem se estabelece na ítegra. Para a primeira fase é prevista a constituição da CPA, o planejamento da autoavaliação por parte dessa e a sensibilização da comunidade acadêmica no trabalho autoavaliativo (BRASIL/Inep/Conaes, 2004b). A rotatividade de membros é ainda uma constante, especialmente porque o trabalho da CPA acaba por sobrecarregar a agenda dos membros, cujas responsabilidades e tarefas não foram amenizadas antes de assumir essa nova responsabilidade. Por um tempo, chegou-se a nem contar com membros da sociedade civil organizada, por exemplo, os quais já têm muitas funções fora da IES. O planejamento da autoavaliação é realizado colaborativamente nas reuniões, geralmente mensais, dos membros, mas, pela própria sobrecarga de trabalho desses e também pelo fato de a CPA não ter uma estrutura própria, que incluiria uma sala de reuniões, vivencia-se problema de foco durante a reunião. A sensibilização, por sua vez, é duplamente desafiadora, visto que tanto os membros da Comissão - em um primeiro momento - como a comunidade, como um todo, desconhecem o que é a autoavaliação. O trabalho, então, é de fazê-los conhecer, valorizar e contribuir. As iniciativas para contornar esse panorama, contudo, são várias: CPA itinerante, Fórum de autoavaliação, Boletim informativo trimestral, entre outras. 
Para a segunda fase - desenvolvimento -, é prevista a concretização das atividades planejadas para a autoavaliação (BRASIL/Inep/Conaes, 2004b); e, aqui, quanto mais ações que consigam fazer da comunidade uma colaboradora ativa da autoavaliação melhor. Todas as ações de sensibilização contribuem, igualmente, para essa fase, não obstante, os instrumentos utilizados para auscultar a comunidade ganham foco. Na UnB, a CPA conta com resultados de instrumentos aplicados pela gestão, e desenvolveram um instrumento próprio de consulta à comunidade, contudo, não obtem uma quantidade sigficativa de respostas. Além do desinteresse dos possíveis respondentes, a consulta possui partes um tanto burocráticas e não individualiza, em termos de questões, os diversos grupos existentes na IES. Com a iniciativa de Bedritichuk (2015) um questionário destinado especificamente aos docentes foi desenvolvido e vem sendo aplicado, desde então, com boa aceitação, segundo a mesma. Positivamente, já está havendo uma compreensão por parte da Comissão da necessidade de ouvir a comunidade a partir de um trabalho mais individualizado, na medida do possível. Como sintetizou um representante da CPA, entrevistado, não adianta se ter uma CPA que "fale de dados gerais da universidade. As pessoas estão interessadas em saber o que está acontecendo com a sua unidade; e também as políticas e as propostas e os problemas são muito particulares. Têm problemas gerais, mas têm problemas muito particulares.”. (DO, informação verbal).

Para a terceira fase, a da consolidação, finalmente, é esperada a elaboração do relatório, a divulgação desse e uma espécie de balanço crítico do processo e resultados, o qual, juntamente com o relatório, em si, promoveria ações em prol de melhorias por parte da gestão. Os dois últimos relatórios de autoavaliação da UnB e as falas dos membros de sua CPA demonstram que esses são reduzidos a uma funcionalidade burocrática também prevista pelos outros entrevistados. Polidos, pouco críticos, excessivamente descritivos e pouco informativos no que tange a metas precisas, os relatórios vêm sendo efetivamente postados no sistema e-MEC, cumprindo a prerrogativa regulatória do Sinaes, que assim o exige. A funcionalidade formativa desse, contudo, que prevê uma gama de ações conscientes por parte da gestão se viabiliza apenas pontualmente.

Mesmo passando por todas essas três fases e tendo uma CPA bastante preparada e atuante, a autoavaliação é algo desconhecido pela comunidade acadêmica e gestão da UnB. Entende-se desconhecido, como esclarecido na nota 63, na página 172, aquilo que se conhece pouco ou nem se conhece; que não tem fama; e/ou que se ignora. (HOUAISS; VILLAR, 2008). E todas essas significações, em maior ou menor medida, enquadram-se na realidade da 
UnB e de diversas IES do país. Fazer da autoavaliação algo reconhecido e valorizado é o grande propulsor de uma melhor implementação das três fases previstas para a autoavaliação.

A UnB, que aqui representa a realidade de muitas outras instituições, necessita incluir de fato todos os seus campi no processo de autoavaliação e chegar ao máximo de pessoas possível em toda a comunidade; continuar revendo os instrumentos aplicados; escrever um relatório mais crítico e menos polido e criar uma ponte duradoura entre resultados de autoavaliação e implementações práticas. O balanço crítico, previsto para a última fase da autoavaliação, vem sendo realizado nos fóruns da CPA. Essas e outras iniciativas precisam expandir, cada vem mais, a fim de que sejam consolidadas.

Claro que a essas necessidades podem-se somar outras que emerjam de falas da comunidade acadêmica, de membros da gestão ou de outros membros da CPA não auscutados neste trabalho. Mas, para tal, é preciso ouvi-los de algum modo - seja a partir da leitura de outras pesquisas de mestrado ou doutorado que se interessem em dar continuidade aos resultados desta, seja em uma conversa formal ou informal entre esses agentes ou instrumentos específicos aos diversos grupos. Como agentes que vivenciam historicamente a autoavaliação, todos têm, certamente, muito a contribuir.

Diante de tamanhos obstáculos a se passar e da visível persistência, por parte da CPA, em alcançar o êxito, faz-se urgente algumas atitudes por parte da gestão e algumas tantas outras por parte ainda dos membros da Comissão. A sobrecarga de trabalho dessa última, de fato, parece não possibilitar nenhuma atitude a mais, mas se gestão e CPA trabalharem juntas, o esforço torna-se admissível e logo a comunidade acadêmica se juntará à causa. A soma da força desses três grupos institucionais (CPA-gestão-comunidade), juntamente com a esperada contribuição de pesquisadores e de instâncias políticas responsáveis, há de conseguir instituir a tão sonhada cultura de avaliação formativa e, especificamente, de autoavaliação.

A partir de omissões históricas do Estado, das IES e, de certa forma, até mesmo de pesquisadores da área de avaliação, que, como visto, muitas vezes concentram suas pesquisas no Enade e não nos demais pilares do Sinaes, chegou-se, irremediavelmente, ao panorama da autoavaliação da UnB. No entanto, uma vez compreendida as bases que levaram às condições vivenciadas, é preciso focar nos avanços futuros. Realmente, esta pesquisa teve como limitação o fato de não ter entrevistado uma quantidade de membros da CPA mais proporcial ao número de representantes de cada segmento (docente, discente, corpo técnico e sociedade civil). Talvez, se tivesse sido previsto fazê-lo, seriam auscutados outras questões e problemáticas. Mesmo assim, os que foram entrevistados demonstraram um grau de detalhamento bastante favorável ao estudo e ainda tiveram suas falas intercaladas e 
contrapostas a representantes da Daes/Inep, da Conaes e de pesquisadores da área, o que contribuiu, sobremaneira, a uma visão macro e micro do objeto. Outras pesquisas de mestrado ou doutorado podem seguir essa tendência ou focalizar na UnB, auscultando, por exemplo, não só membros da CPA, mas também da gestão.

Os resultados obtidos com esta pesquisa e, por sua vez, as proposições realizadas tiveram como principal objetivo auxiliar a instituição corpus, bem como outros contextos parecidos em igual, menor ou maior medida. Um dos interlocutores do trabalho, quando perguntado qual sua análise acerca do papel da autoavaliação dentro do contexto do Sinaes, respondeu o seguinte: "Atualmente? Nenhuma. Ela era central. Ela era para estabelecer um diálogo. E hoje, ao longo do Sinaes, ela tem um papel burocrático.”. (P1, informação verbal). Respostas diferentes a essa pergunta são possíveis. Basta que sem postergar mudanças ou transferir a responsabilidade a outros, cada pessoa - influenciadora direta ou indireta da prática autoavaliativa - faça sua parte. Aquela qualidade da educação superior que não se reduz a notas e rankings é o que está em jogo. 


\section{REFERÊNCIAS}

ADRIOLA, Wagner Bandeira; SOUZA, Laura Alves de. Representações sociais dos gestores e dos técnicos das unidades acadêmicas da Universidade Federal do Ceará (UFC) acerca da autoavaliação institucional. Avaliação, Campinas, v. 15, n. 2, p. 45-72, jul. 2010. Disponível em: 〈http://www.scielo.br/pdf/aval/v15n2/a03v15n2.pdf>. Acesso em: 20 out. 2014.

AFONSO, Almerindo Janela. Mudanças no Estado avaliador: comparativismo internacional e teoria da modernização revisitada. Revista Brasileira de Educação, Rio de Janeiro, v. 18, n. 53, p. 267-490, abr/jun. 2013. Disponível em: <http://www.scielo.br/pdf/ rbedu/v18n53/02.pdf >. Acesso em: 10 nov. 2014.

ALMEIDA, Tabajara Lucas de. PINTO, Suzi Samá; PICCOLI, Humberto Camargo. Autoavaliação na Fundação Universidade Federal do Rio Grande: metodologia de avaliação. Avaliação, Campinas, v. 12, n. 3, p. 515-530, set. 2007. Disponível em: < http://www.scielo.br/pdf/aval/v12n3/a08v12n3.pdf>. Acesso em: 10 nov. 2014

ALVES-MAZZOTTI, Alda Judith. Usos e abusos dos estudos de caso. Cadernos de Pesquisa, São Paulo, v. 26, n 129, p. 637-651, dez. 2006. Disponível em: <http://www.scielo.br/pdf/cp/v36n129/a0736129.pdf>. Acesso em: 12 mar. 2014.

ARGOLLO, Rivailda Silveira Nunes. Autoavaliação institucional na Rede Federal de Educação Tecnológica: análise da implementação do SINAES. 2010. 193f. Dissertação (Mestrado) - Universidade Federal da Bahia, Programa de Pós-Graduação em Educação, Bahia, 2010.

ASSIS, Lúcia Maria de. Avaliação institucional e prática docente na educação superior: tensões, mediações e impactos. 2008. 244f. Tese (Doutorado) - Universidade Federal de Goiás, Programa de Pós-Graduação em Educação, Goiânia, 2008.

OLIVEIRA, João Ferreira de. A avaliação da educação superior no contexto das reformas e políticas educacionais. Linhas Críticas, Brasília, v. 19, n. 38, p. 51-69, jan/abr. 2013. Disponível em: <http://www.cdn.ueg.br/arquivos/PRG/noticias/12374 /_5Artigo_Linhas_Criticas_2012.pdf>. Acesso em: 12 mar. 2014.

AZEVEDO, Carlos Eduardo Franco; OLIVEIRA, Leonel Gois Lima; GONZALES, Rafael Kuramato; ABDALLA, Márcio Moutinho. A Estratégia de Triangulação: Objetivos, Possibilidades, Limitações e Proximidades com o Pragmatismo. In: IV ENCONTRO DE ENSINO E PESQUISA EM ADMINISTRAÇÃO E CONTABILIDADE, 4., 2013, Brasília. Anais... Brasília: Enepq, 2013. p. 1 - 16. v.1. 
BANCO MUNDIAL. Higher Education in developing countries: peril and promise. Washington: Banco Mundial, 2000. Disponível em: <http://siteresources.worldbank .org/EDUCATION/Resources/278200-1099079877269/547664-1099079956815/peril_ promise_en.pdf $>$. Acesso em: 10 nov. 2015.

La enseñaza superior: las experiencias derivadas de la experiencia. Washington: Banco Mundial, 1995. Disponível em: <http://firgoa.usc.es/drupal/files/010-1344Sp.pdf>. Acesso em: 10 fev. 2014.

BANDEIRA ADRIOLA, Wagner; SOUZA, Laura Alves de. Representações sociais dos gestores e dos técnicos das unidades acadêmicas da Universidade Federal do Ceará (UFC) acerca da autoavaliação institucional. Avaliação, Campinas, v. 15, n. 2, p. 45-72, jul. 2010. Disponível em: < http://www.scielo.br/pdf/aval/v15n2/a03v15n2.pdf> Acesso em: 15 jan. 2015.

BARDIN, Laurence. Análise de conteúdo. 3. ed. Lisboa: Edições 70, 2004.

BARREYRO, Gladys Beatriz. De exames, rankings e mídia. Avaliação, Campinas, v. 13, n. 3, p. 863-868, nov. 2008. Disponível em: 〈http://www.scielo.br/pdf/ aval/v13n3/17.pdf〉. Acesso em: 20 fev. 2015.

ROTHEN, José Carlos. História da avaliação superior no Brasil 1980-1992: concepções e atores. In: VIII CONGRESO IBEROAMERICANO DE HISTÓRIA DE LA EDUCACIÓN LATINOAMERICANA, 8., 2007, Buenos Aires. Anais... Buenos Aires: Sociedad Argentina de Historia de la Educación, 2007. p. 9. v. 1.

Percurso da avaliação da educação superior nos Governos Lula. Educação e Pesquisa, São Paulo, v. 40, n. 1, p. 61-76, jan/mar. 2014. Disponível em: <http://www.scielo.br/pdf/ep/v40n1/05.pdf>. Acesso em: 27 ago. 2015.

Sinaes contraditórios: considerações sobre a elaboração e implantação do Sistema Nacional de Avaliação da Educação Superior. Educação e Sociedade, Campinas, v. 27 n. 96, p. 955-977, out. 2006. Disponível em: <http://www.scielo.br/pdf/ es/v27n96/a15v2796.pdf>. Acesso em: 22 set. 2014.

BARROSO, João. A regulação das políticas públicas da educação: espaço, dinâmicas e atores. Lisboa: Educa/Unidade de I\&D de Ciências da Educação, 2006.

O Estado, a educação e a regulação das políticas públicas. Educação e Sociedade. Campinas, v 26, n. 92, p. 725-751, out. 2005. Disponível em: < http://www.scielo.br/pdf/es/v26n92/v26n92a02.pdf>. Acesso em: 13 jan. 2016. 
BEDRITICHUK, Amanda Guedes Andrade. Um instrumento de avaliação docente para a Universidade de Brasília: uma construção nos moldes do Sinaes. 2015. 149f. Dissertação (Mestrado) - Universidade de Brasília, Programa de Pós-Graduação em Educação, Brasília, 2015.

BELLONI, Isaura. Avaliação Institucional: um instrumento de democratização da educação. Linhas Críticas. v. 5, n. 9, p. 31-58, jul/dez. 1999. Disponível em: < http://periodicos.unb.br/index.php/linhascriticas/article/view/6711/5418>. Acesso em: 7 mai. 2014.

BELLONI, José Ângelo; BORGES, Mariza Monteiro; SOBRAL, Dejano Tavares. Avaliação institucional da Universidade de Brasília. 1995. In: BALZAN; Newton Cesar; DIAS SOBRINHO, José. (Org.) Avaliação Institucional: teoria e experiências. 4. ed. São Paulo: Cortez, 2008, p. 87-114.

KIPNIS, Bernardo; SERAFINI, Oscar. Avaliação do ensino de graduação: teste da metodologia 1987. Brasília: Editora UnB, 1980.

BERTOLIN, Júlio César Godoy. Avaliação da qualidade do sistema de educação superior brasileiro em tempos de mercantilização: período 1994-2003. 2007. 282f. Tese (Doutorado) - Universidade Federal do Rio Grande do Sul, Programa de Pós-Graduação em Educação, Porto Alegre, 2007.

Os quase-mercados na educação superior: dos improváveis mercados perfeitamente competitivos à imprescindível regulação do Estado. Educação e Pesquisa. São Paulo, v. 37, n. 2, p. 237-248, mai/ago. 2011. Disponível em: <http://www.scielo.br/pdf/ep/v37n2/v37n2a02.pdf>. Acesso em: 18 out. 2015.

. Qualidade em educação superior: da diversidade de concepções a inexorável subjetividade conceitual. Avaliação. Campinas, v.14, n.1, p. 127-149, mar. 2009. Disponível em: 〈http://www.scielo.br/pdf/aval/v14n1/a07v14n1.pdf>. Acesso em: 2 mai. 2015.

BITTENCOURT, Hélio Radke; CASARTELLI, Alam de Oliveira; RODRIGUES, Alziro César de Morais. Sobre o índice geral de cursos (IGC). Avaliação, Campinas, v. 14, n. 3, p. 667-682, nov. 2009. Disponível em: 〈http://www.scielo.br/pdf/ aval/v14n3/a08v14n3.pdf〉. Acesso em: 25 set. 2015.

BONETI, Lindomar Wessley. GISI, Maria Lourdes; FILIPAK, Sirley Terezinha. Do direito à educação superior ao desafio do acesso para todos. Revista Diálogo Educacional, Curitiba, v. 13, n. 39, p. 521-540, maio/ago. 2013. Disponível em: < http://www2.pucpr.br/reol/pb/index.php/dialogo?dd1=10203\&dd99=view\&dd98=pb>. Acesso em: 20 jan. 2016. 
BONI, Valdete; QUARESMA, Silva Jurema. Aprendendo a entrevistar: como fazer entrevistas em Ciências Sociais. Revista Eletrônica dos Pós-Graduandos em Sociologia Política da UFSC, São Carlos, v. 2, n. 1, p. 68-80, jan/jul. 2005. Disponível em: < https://periodicos.ufsc.br/index.php/emtese/article/viewFile/18027/16976>. Acesso em: 5 jan. 2016.

BOTELHO, Arlete de Freitas; SOUSA, José Vieira de. Autoavaliação Institucional: um olhar sobre indicadores sociais propostos pelo Sinaes. XII ENCONTRO DE PESQUISA EM EDUCAÇÃO DA REGIÃO CENTRO-OESTE, 12., 2014, Goiânia. Anais... Goiânia: PUCGO, 2014. v. 1.

BOURDIEU. Pierre. Contrafogos: táticas para enfrentar a invasão neoliberal. Rio de Janeiro: Jorge Zahar, 1998.

BRASIL. Constituição (1988). Constituição da República Federativa do Brasil. Brasília, DF: Senado Federal, 1988.

Decreto $\mathrm{n}^{\circ} 5.773$ de 9 de maio de 2006. Dispõe sobre o exercício das funções de regulação, supervisão e avaliação de instituições de educação superior e cursos superiores de graduação e sequenciais no sistema federal de ensino. Diário Oficial da União, Brasília, DF, 10 mai. 2006.

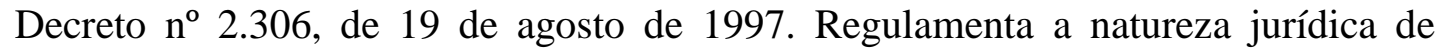
entidades mantenedoras de instituições de ensino superior. Diário Oficial da União, Brasília, DF, 20 ago. 1997.

Decreto $\mathrm{n}^{\circ}$ 2.026, de 10 de outubro de 1996. Revogado pelo Decreto 3.860, de 9 de julho de 2001. Estabelece procedimentos para o processo de avaliação dos cursos e instituições de ensino superior. Diário Oficial da União, Brasília, DF, 10 out. 1996.

Lei $n^{\circ} 13.005$, de 25 de junho de 2014. Aprova o Plano Nacional de Educação e dá outras providências. Diário Oficial da União, Brasília, DF, 26 jun. 2014.

Lei $\mathrm{n}^{\circ}$ 10.861, de 14 de abril de 2004. Institui o Sistema Nacional de Avaliação da Educação Superior - Sinaes e dá outras providências. Diário Oficial da União, Brasília, DF, 15 abr. 2004a.

Lei $\mathrm{n}^{\circ}$ 10.172, de 9 de janeiro de 2001. Aprova o Plano Nacional de Educação e dá outras providências. Diário Oficial da União, Brasília, DF, 10 jan. 2001. 
Lei $\mathrm{n}^{\circ}$ 9.448, de 14 de março de 1997. Transforma o Instituto Nacional de Estudos e Pesquisas Educacionais - Inep em Autarquia Federal, e dá outras providências. Diário Oficial da União, Brasília, DF, 15 mar. 1997.

Lei $\mathrm{n}^{\circ}$ 9.394, de 20 de dezembro de 1996. Estabelece as Diretrizes e Bases da Educação Nacional. Diário Oficial da União, Brasília, 23 dez. 1996.

Lei n. 9.131, de 24 de novembro de 1995. Altera dispositivos da Lei n. ${ }^{\circ} 4.024$, de 20 de dezembro de 1961, dispõe sobre as atribuições do Ministério da Educação e do Desporto, institui o Conselho Nacional de Educação e dá outras providências. Diário Oficial da União, Brasília, DF, de 25 nov. 1995.

Lei n.3.998, de 15 de dezembro de 1961. Autoriza o Poder Executivo a instituir a Fundação Universidade de Brasília, e dá outras providências. Diário Oficial da União, Brasília, DF, de 15 de dezembro de 1961.

Medida Provisória 147, de 15 de dezembro de 2003. Institui o Sistema Nacional de Avaliação e Progresso do Ensino Superior e dispõe sobre a avaliação do ensino superior. Diário Oficial da União, Brasília, DF, 15 dez. 2003c.

Portaria $\mathrm{n}^{\mathrm{o}} 1.027$, de 15 de maio de 2006. Dispõe sobre banco de avaliadores do Sistema Nacional de Avaliação da Educação Superior - Sinaes, sobre a criação da Comissão Técnica de Acompanhamento da Avaliação - CTAA, e dá outras providências. Diário Oficial da União, Brasília, DF, 15 mai. 2006b.

Portaria $\mathrm{n}^{\circ}$ 19, de 17 de maio de 2003. Designa membros para Comissão Especial de Avaliação. Diário Oficial da União, Brasília, DF, 28 maio 2003b, n. 101, Seção 2, p. 11.

Portaria ${ }^{\circ} 11$, de 28 de abril de 2003. Institui a Comissão Especial de Avaliação. Diário Oficial da União. Brasília, DF, 30 abr. 2003a., n. 82, Seção 2, p. 19.

COMISSÃO ESPECIAL DE AVALIAÇÃO (CEA). Sistema Nacional de Avaliação da Educação Superior (Sinaes): bases para uma proposta da educação superior. Brasília, DF: ed. do MEC. 2003.

Instituto Nacional de Pesquisas e Estudos Educacionais Anísio Teixeira - Inep. Portaria Inep n ${ }^{\circ} 239$, de 10 de junho de 2015. Dispõe sobre características do Enade 2015 e dá outras providências. Diário Oficial da União, Brasília, DF, 12 jun. 2015. 
Brasília: Inep, 2011.

Sistema Nacional de Avaliação da Educação Superior (Sinaes). v. 3. . Sinaes - Sistema Nacional de Avaliação da Educação Superior: da concepção à regulamentação. 5. ed. revisada e ampliada. Brasília: Inep, 2009.

Comissão Nacional de Avaliação da Educação Superior - Conaes. Nota Técnica $\mathrm{n}^{\mathrm{o}}$ 65, de 09 de outubro de 2014. Roteiro para relatório de Autoavaliação Institucional. Diário Oficial da União, Brasília, DF, 04 fev. 2014.

Sistema Nacional de Avaliação da Educação Superior: diretrizes para a avaliação das instituições de educação superior. Brasília, 2004a.

Sistema Nacional de Avaliação da Educação Superior:

orientações gerais para o roteiro da auto-avaliação das instituições. Brasília, 2004b.

Diretoria de Avaliação da Educação Superior - Daes. Instrumento de avaliação de cursos de graduação presencial e à distância. Brasília, DF, mar. 2015.

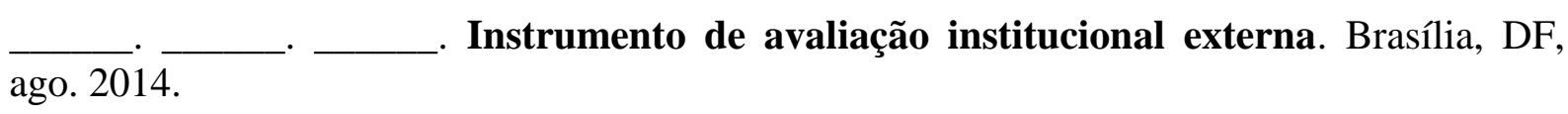

. Ministério da Educação. Portaria no 92 de 31 de janeiro de 2014. Aprova em extrato os indicadores do Instrumento de Avaliação Institucional Externa para os atos de credenciamento, recredenciamento e transformação de organização acadêmica, modalidade presencial, do Sistema Nacional de Avaliação da Educação Superior - Sinaes. Diário Oficial da União, no 2, Seção 1, Brasília, DF, 4 fev. 2014.

. Portaria Normativa $\mathrm{n}^{\mathrm{o}}$ 40, de 12 de dezembro de 2007, consolidada em 29 de dezembro de 2010. Institui o e-MEC, sistema eletrônico de fluxo de trabalho e gerenciamento de informações relativas aos processos de regulação, avaliação e supervisão da educação superior no sistema federal de educação, e o Cadastro e-MEC de Instituições e Cursos Superiores e consolida disposições sobre indicadores de qualidade, banco de avaliadores (BASis) e o Exame Nacional de Desempenho de Estudantes (Enade) e outras disposições. Diário Oficial da União, $n^{\circ} 249$, Seção 1, Brasília, DF, 29 dez. p. 23-31, 2010.

Portaria $\mathrm{n}^{\circ} 302$ de 7 de abril de 1998. Normatiza os procedimentos de avaliação do desempenho individual das instituições de ensino superior. Diário Oficial da União, Brasília, DF, 7 abr. 1998. 
Portaria $n^{\circ} 170$ de 3 de março de 1986. Formaliza a criação do Grupo Executivo para a Reformulação da Educação Superior. Diário Oficial da União, Brasília, DF, 3 mar. 1986.

Secretaria de Educação Superior. Portaria no 11, de 28 de abril de 2003. Com a finalidade de analisar, oferecer subsídios, fazer recomendações, propor critérios e estratégias para a reformulação dos processos e políticas de avaliação da Educação Superior e elaborar a revisão crítica dos seus instrumentos, metodologias e critérios utilizados. Diário Oficial da União, Brasília, DF, 30 abr. 2003.

Portaria $\mathrm{n}^{\mathrm{o}} 130$, de 14 de julho de 1993. Cria Comissão com o objetivo de estabelecer diretrizes e viabilizar a implementação do processo de avaliação institucional nas universidades brasileiras. Diário Oficial da União. Brasília, DF, 3 jul. 1993. BRUNNER, José Joaquim. Universidad, sociedad y Estado en los 90. Nueva Sociedad, n. 107, p. 70-76, mai/jun. 1990. Disponível em: < http://nuso.org/media/articles/ downloads/1874_1.pdf>. Acesso em 12 jan. 2016.

BURLAMAQUI, Marco Guilherme Bravo. Avaliação e qualidade na educação superior: tendências na literatura e algumas implicações para o sistema de avaliação brasileiro. Estudos em Avaliação Educacional, v. 19, n. 39, jan/abr. 2008. Disponível em: < http://www.fcc.org.br/pesquisa/publicacoes/eae/arquivos/1422/1422.pdf>. Acesso em: 16 fev. 2014.

CARDOSO, Roberta Muriel; DIAS SOBRINHO, José. Avaliação e educação no Brasil: avanços e retrocessos. Série-Estudos. Campo Grande, n. 37, p. 263-273, jan/jun. 2014. Disponível em: <http://www.serie-estudos.ucdb.br/index.php/serie-estudos/article/view/ 766>. Acesso em: 19 fev. 2016.

COLETA, José Augusto Dela; COLETA, Marília Ferreira Dela. Cultura organizacional e avaliação de instituições de educação superior: semelhanças e diferenças. Psico-USF. Itatiba, n. 2, p. 227-237, jul/dez. 2007. Disponível em: <pepsic.bvsalud.org/scielo.php>. Acessp em: 11 mai. 2016.

COMISSÃO NACIONAL DE AVALIAÇÃO DA EDUCAÇÃO SUPERIOR. Brasília. Ata da $99^{\circ}$ reunião ordinária da Conaes realizada no dia 21 de agosto de 2013. p. 2.

de 2011. p. 2.

Brasília. Ata da $72^{\circ}$ reunião ordinária da Conaes realizada no dia 13 de janeiro

Website. Conheça a Conaes. Disponível em<http://portal.mec.gov.br/component/ content/ article?id=13082:apresentacao-conaes>. Acesso em: 20 dez. 2015. 
COORDENAÇÃO DE APERFEIÇOAMENTO DE PESSOAL DE NÍVEL SUPERIOR. Website. Institucional. Disponível em: http://www.capes.gov.br/acessoainformacao/institucional>. Acesso em 15 jan. 2016.

CRESWELL, John, W. Projeto de pesquisa: métodos qualitativo, quantitativo e misto. 3. ed. Porto Alegre: Artmed, 2010.

CUNHA, Aldenéia Soares da. Autoavaliação Institucional: perspectivas de melhorias ou mero cumprimento de obrigação? In: SEMINÁRIOS REGIONAIS SOBRE AUTOAVALIAÇÃO INSTITUCIONAL E COMISSÕES PRÓPRIAS DE AVALIAÇÃO (CPA), 2013, Anais... 2013. p.1-13. v.1.

CUNHA, Débora Alfaia da. Avaliação da Educação Superior: condições, processos e efeitos da autoavaliação nos cursos de graduação da UFPA. 2010. 355f. Tese (Doutorado). Universidade de Brasília, Programa de pós-graduação em Educação, Brasília, 2010.

CUNHA, Luiz Antônio. Nova reforma do ensino superior: a lógica reconstruída. Cadernos de pesquisa, São Paulo, n. 101, p. 20-49, jul. 1997. Disponível em: < http://publicacoes.fcc.org.br/ojs/index.php/cp/article/view/751>. Acesso em: 10 nov. 2015.

O ensino superior no octênio FHC. Educação e Sociedade, Campinas, v. 24, n. 82, p. 37-61, abr. 2003. Disponível em: 〈http://www.scielo.br/pdf/es/v24n82/ a03v24n82.pdf>. Acesso em: 13 mar. 2015.

CURY, Carlos Roberto Jamil. Educação e contradição: elementos metodológicos para uma teoria crítica do fenômeno educativo. 3. ed. São Paulo: Cortez, 1987.

DEMO, Pedro. Política social, educação e cidadania. 3. ed. Campinas: Papirus, 1994.

DIAS, Carmem Lúcia; HORIGUELA, Maria de Lourdes Morales; MARCHELLI; Paulo Sérgio. Políticas para avaliação da qualidade do Ensino Superior no Brasil: um balanço crítico. Educação e Pesquisa, São Paulo, v.32, n.3, p. 435-464, set/dez. 2006. Disponível em: < http://www.scielo.br/pdf/ep/v32n3/a02v32n3.pdf >. Acesso em: 18 fev. 2016.

DIAS SOBRINHO, José. Avaliação da educação superior - regulação e emancipação. Avaliação, Campinhas, v. 8, n. 1, p. 31-47, mar. 2003. Disponível em: < http://periodicos.uniso.br/ojs/index.php?journal=avaliacao\&page=article \&op=view \&path[]=1 221\&path[]=1211>. Acesso em: 4 abr. 2014. 
Avaliação e transformações da educação superior brasileira (1995-2009): do provão ao SINAES. Avaliação, Campinas, v.15, n.1, p.195-224, mar. 2010. Disponível em: <http://www.scielo.br/pdf/aval/v15n1/v15n1a11.pdf>. Acesso em: 9 mai. 2014.

Avaliação ética e política em função da educação como direito público ou como mercadoria? Educação e Sociedade, Campinas, v. 25, n. 88, p. 703-725, out. 2004. Disponível em: <http://www.scielo.br/pdf/es/v25n88/a04v2588.pdf>. Acesso em: 23 nov. 2014.

Qualidade, avaliação: do Sinaes a índices. Avaliação, Campinas, v. 13, n. 3, p. 817825, nov. 2008. Disponível em: 〈http://www.scielo.br/pdf/aval/v13n3/11.pdf>. Acesso em: 12 jan. 2015.

DICIO - Dicionário Online de Português. Website. Dicionário de língua portuguesa. Disponível em: < http://www.dicio.com.br/> . Acesso em 20 mai. 2016.

DICIONÁRIO DE SINÔNIMOS. Website. Dicionário de sinônimos da língua portuguesa. Disponível em: < http://www.sinonimos.com.br/>. Acesso em 25 mai. 2016.

DOURADO, Luiz Fernandes. Reforma do estado e as políticas para a educação superior no Brasil nos anos 90. Educação e Sociedade, Campinas, v. 23, n. 80, set. 2002, p. 234-252. Disponível em: <http://www.scielo.br/pdf/es/v23n80/12931.pdf>. Acesso em: 7 mar. 2015.

OLIVEIRA, João Ferreira de. A qualidade da educação: perspectivas e desafios. Caderno Cedes, Campinas, v. 29, n. 78, p. 201-215, maio/ago. 2009. Disponível em: <http://www.scielo.br/pdf/ccedes/v29n78/v29n78a04>. Acesso em: 10 abr. 2015.

DUARTE, Ana Lúcia Cunha. Exame Nacional de Desempenho dos Estudantes: uma análise do uso dos resultados no curso de pedagogia da UEMA. 2013. 327f. Tese (Doutorado) - Universidade de Brasília, Programa de pós-graduação em Educação, Brasília, 2013.

FÁVERO, Maria de Lourdes de A; SGUISSARDI, Valdemar. Quantidade/qualidade e educação superior. Revista Educação em Questão, Natal, v. 42, n. 28, p. 61-88, jan/abr. 2012. Disponível em: <http://www.periodicos.ufrn.br/educacaoemquestao/ article/view/4053>. Acesso em: 17 jun. 2014.

FÉLIX, Antônio Ferreira. O caráter pedagógico da atividade sindical e os limites do economicismo. 2013. 158f. Dissertação (Mestrado) - Universidade Federal do Ceará, Programa de Pós - graduação em Eduçção Brasileira, Fortaleza, 2013. 
FERNANDES, Florestan. Circuito fechado: quatro ensaios sobre o "poder institucional". São Paulo: Hucitec, 1976.

FONSECA, Marília; OLIVEIRA, João Ferreira de. Avaliação institucional nas instituições de educação superior - mecanismos de articulação entre avaliação e gestão universitária. Cadernos ANPAE. v. 1, p. 1-19, 2007. Disponível em: < http://www.anpae.org.br/congressos_antigos/simposio2007/314.pdf>. Acesso em: 22 fev. 2015.

FREITAS, Márcia de Souza Luz; CUNHA, Cibele Faria. Desenvolvimento de estratégias de sensibilização: considerações acerca da identidade institucional e sua importância no estabelecimento da cultura avaliativa. In: SEMINÁRIOS REGIONAIS SOBRE AUTOAVALIAÇÃO INSTITUCIONAL E COMISSÕES PRÓPRIAS DE AVALIAÇÃO (CPA), 1., 2010, Brasília. Anais... Brasília: Inep, 2010. p. 1 - 15. v.1.

GARCIA, Marta Fernandes; ESPINDOLA, Adriana Andrade; SORDI, Maria Regina Lemes de. Processo de implementação do Sinaes: contradições, tensões e possibilidades. Revista ibero-americana de estudos em educação. São Paulo, v. 6, n. 3, 2011. Disponível em: <http://seer.fclar.unesp.br/iberoamericana/article/view/4998>. Acesso em: 12 mar. 2015.

GADOTTI, Moacir. Concepção dialética da educação: um estudo introdutório. 3. ed. São Paulo: Cortez, 1984.

Qualidade na educação: uma nova abordagem. In: CONGRESSO DE EDUCAÇÃO BÁSICA: QUALIDADE NA APRENDIZAGEM, 1., 2013, Florianópolis. Anais... Florianópolis: Coeb, 2013. p. 1 - 18. v.1.

GASPAR, Ronaldo Fabiano; FERNANDES, Tânia Costa. Oligopolização e precarização do trabalho docente no ensino superior privado brasileiro: causas, conexões e consequências. Revista Espaço Acadêmico, Maringá, v. 14, n. 168, p. 77-92, mai. 2015. Disponível em: <http://www.periodicos.uem.br/ojs/index.php/EspacoAcademico/article/view/23232>. Acesso em: 20 jan. 2016.

GIL, Antônio, Carlos. Métodos e técnicas de pesquisa social. 6. ed. São Paulo: Atlas, 2008.

GIOLO, Jaime. A educação superior brasileira: a recente expansão privada. In: IX COLÓQUIO INTERNACIONAL SOBRE GESTÃO UNIVERSITÁRIA NA AMÉRICA DO SUL, 9., 2009, Florianópolis. Anais... Florianópolis: UFSC, 2009. p. 1 -14. v. 1.

GONÇALVES, Lukelly Fernanda Amaral. El Estado brasileño y las políticas de evaluación de la educación superior: de una evaluación controladora a una formativa. In: VI 
CONGRESO INTERNACIONAL EDUCATIVO MULTIDISCIPLINARIO - CIEM, 6., 2015, Guadalajara. Anais... Guadalajara: Sistema Valladolid, 2015. p. 291 - 299. v. 1.

. SOUSA, José Vieira de. O Sistema de Avaliação da Educação Superior - Sinaes e o trabalho docente: um estudo exploratório. In: XXIV Seminário Nacional da Rede Universitas/Br, 24, Maringá. Anais... Maringá: UEM, 2016. p. 1-15. v. 1.

GONTIJO, Simone Braz Ferreira. Implicações do Enade para a organização do trabalho pedagógico e as práticas avaliativas em um curso de pedagogia. 2014. 302f. Tese (Doutorado) - Universidade de Brasília, Programa de Pós-Graduação em Educação, Brasília, 2014.

GOVERNO DO DISTRITO FEDERAL. Lei n ${ }^{\circ}$ 2.676, de 12 de janeiro de 2001. Dispõe sobre a criação da Fundação de Ensino e Pesquisa em Ciências da Saúde. Diário Oficial do Distrito Federal, Brasília, 12 jan. 2001.

GRIBOSKI, Claudia Maffini. Regular e/ou induzir qualidade? - os cursos de pedagogia nos ciclos avaliativos do Sinaes. 2014. 482f. Tese (Doutorado) - Universidade de Brasília, Programa de Pós-Graduação em Educação, Brasília, 2014.

HARVEY, David. Condição pós-moderna. 16. ed. São Paulo: Edições Loyola, 1992.

HÖFLIN, Eloisa de Mattos. Estado e Políticas (Públicas) Sociais. Cadernos CEDES, São Paulo, v. 21, n. 55, p. 30-41, nov. 2001. Disponível em: < http://scielo.br/pdf/ccedes/v21n55/5539>. Acesso em: 27 jan. 2014.

HORA, Paola Matos da. Sentidos e significados do índice geral de cursos na regulação da qualidade da educação superior. 2013. 242f. Dissertação (Mestrado) - Universidade de Brasília, Programa de Pós-Graduação em Educação, Brasília, 2013.

HOUAISS, Antônio; VILLAR, Mauro de Salles. Mini dicionário Houaiss da língua portuguesa. 3. ed. Rio de Janeiro: Objetiva, 2008.

INSTITUTO BRASILEIRO DE GEOGRAFIA E ESTATÍSTICA. Website. Cidades. Disponível em: < http://cidades.ibge.gov.br/xtras/perfil.php?codmun=530010>. Acesso em 25 mai. 2016.

INSTITUTO BRASILEIRO DE INFORMAÇÃO EM CIÊNCIA E TECNOLOGIA. Website. Sobre o Ibict. Disponível em: < http://www.ibict.br/sobre-o-ibict>. Acesso em: 15 jan. 2016. 
INSTITUTO NACIONAL DE ESTUDOS E PESQUISAS EDUCACIONAIS. Sinopse Estatística da Educação Superior - 2014. Brasília: Inep, 2015.

IVASHITA, Simone Burioli; NOVAK, Maria Simone Jacomini; BERTOLLETI, Vanessa Alves. O ensino superior na perspectiva do Banco Mundial: algumas considerações. In: IX CONGRESSO NACIONAL DE EDUCAÇÃO - EDUCARE E III ENCONTRO BRASILEIRO DE PSICOPEDAGOGIA. 9., 3., 2009, Curitiba. Anais... Curitiba: PUCPR, 2009. p. $9.354-9.365$. v. 1.

KELLS, H. R. Perspectivas básicas de regulação. In: Sousa, Eda C. B. Machado de. (Org.). Avaliação institucional: leituras complementares. Brasília: UnB/FE, Curso de Especialização em Avaliação a Distância, v. 8, 1999. Cap. 1, p.7-35.

KONDER, Leandro. O que é dialética? 22. ed. São Paulo: Brasiliense, 1991.

KOSIK, Karel. Dialética do concreto. Rio de Janeiro: Paz e Terra, 1976.

KRAPÍVINE, V. O que é materialismo dialético. Moscou: Livraria Progresso, 1986.

KUENZER, Acácia Zeneida. Desafios teórico-metodológicos da relação trabalho-educação e o papel social da escola. In: FRIGOTTO, Gaudêncio (Org.). Educação e crise do trabalho: perspectivas de final do século. 10 ed. Petrópolis: Vozes, 2011.

LEFEBVRE, Henri. Lógica dialética / lógica formal. Rio de Janeiro: Civilização Brasileira, 1979.

LEHER, Roberto. Projetos e modelos de autonomia e privatização das universidades públicas. Revista da Associações dos docentes da Universidade Estadual de Londrina, Londrina, v. 1. n. 1, p. 7-20, set. 2003. Disponível em: < http://web.sercomtel.com.br/aduel/revista\%20autonomia/auton_priv.pdf>. Acesso em: $12 \mathrm{dez}$. 2015.

LEHFELD, Neide Aparecida de Souza; GARBARRA, Manoel Henrique Cintra; COSTA, Caetano da; SOUSA, Yara Terezinha Correa Silva. Reflexões sobre o processo de autoavaliação institucional: o olhar de uma Comissão Própria de Avaliação. Avaliação, Campinas, v. 15, n. 1, p. 177-194, mar. 2010. Disponível em: < http://www.scielo.br/pdf/aval/v15n1/v15n1a10.pdf>. Acesso em: 10 nov. 2015. 
LEITE, Denise. Ameaças pós-rankings: sobrevivência das CPAs e da auto-avaliação. Avaliação, Campinas, v. 13, n. 3, p. 833-840, nov. 2008. Disponível em: <http://www.scielo.br/pdf/aval/v13n3/13.pdf>. Acesso em: 25 out. 2015.

LEMOS, Valter Victorino. A influência da OCDE nas políticas públicas de educação em Portugal. 2014. 319f. Tese (Doutorado) - Instituto Universitário de Lisboa. Programa de pósgraduação em Políticas Públicas, Lisboa, 2014.

LIMA, Silvia Peixoto de.; RODRÍGUEZ, Margarita Victoria. Políticas educacionais e equidade: revendo conceitos. Contrapontos, Itajaí, v. 8, n. 1, p. 53-70, jan./abr. 2008. Disponível em: < http://siaiap32.univali.br/seer/index.php/rc/article/view/936/791>. Acesso em: 04 jul. 2016.

LOURENÇO, Olimpio Sabino. Avaliação institucional: utilização de resultados na universidade de Brasília (1987 a 1993). 1998. 175f. Dissertação (Mestrado) - Universidade de Brasília, Programa de Pós-Graduação em Educação, Brasília, 1998.

MABA, Elita Grosch. A autoavaliação institucional no processo de tomada de decisão em IES: estudo de caso das faculdades Senac/SC. 2010. 232f. Dissertação (Mestrado) Universidade do Vale do Itajaí, Programa de pós-graduação em Administração, Biguaçu, 2010.

MARINHO, Sidnei Vieira. A autoavaliação institucional no processo de tomada de decisão em IES: Estudo de caso das faculdades SENAC/SC. Avaliação, Campinas, v. 17, n. 2, p. 455-480, jul. 2012. Disponível em: < http://www.scielo.br/pdf/aval/v17n2/09.pdf>. Acesso em: 10 mar. 2016.

MACCARI, Emerson Antônio; CORREIA LIMA, Manolita; RICCIO, Edson Luíz. Uso do Sistema de Avaliação da CAPES por Programas de Pós-Graduação em Administração no Brasil. Revista de Ciências da Administração, Florianópolis, v. 11, n. 25, p. 68-96, set/dez, 2009. Disponível em: <https://periodicos.ufsc.br/index.php/ adm/article/view/13077>. Acesso em: 20 fev. 2016.

MARTINS, Carlos Benedito. A reforma universitária de 1968 e a abertura para o ensino superior privado no Brasil. Educação e Sociedade. Campinas, v. 30, n. 106, p. 15-35, jan/abr. 2009. Disponível em: <http://www.scielo.br/pdf/es/v30n106/v30n106a02〉. Acesso em: 5 jan. 2016.

MARX, Karl; O capital: crítica da economia política.vol. I. tomo I. São Paulo: Abril Cultural, 1983. 
ENGELS, Friedrich. A ideologia alemã. Tradução de José Carlos Bruni e Marco Aurélio Nogueira. São Paulo: Hucitec, 1996.

MENDES, Juliana Camila Barbosa; FRANGELLA, Rita de Cássia P. Avaliação: te olhei por um monóculo e enxerguei a prova. Roteiro. Joaçaba, v. 39, n. 2, p. 331-346, jul/dez. 2014. Disponível em: <http://www.bib.unesc.net/arquivos/30000/34400/ 11_34431.htm>. Acesso em: 12 jan. 2015.

MENEGHEL, Stela Maria. Entrevista. [jan. 2015]. Entrevistadores: Fabiane Robl, Paulo Eduardo Dias de Mello, Claudia Sapag Ricci e Claisy Marinho-Araújo. Revista História Hoje, v. $4, n^{\circ} 7$, p. 189-190.

ROBL, Fabiane; SILVA, Tattina T. Freitas da. A relação entre avaliação e regulação na Educação Superior: elementos para o debate. Educar. Curitiba, n. 28, p. 89-106, 2006. Disponível em: <http://www.scielo.br/pdf/ er/n28/a07n28.pdf>. Acesso em: 22 mar. 2014.

MENEZES, Ângela Maria de. Autoavaliação como instrumento de gestão na educação superior: o caso do Instituto Federal de Educação, Ciência e Tecnologia de Goiás - IFG. 2012. 174f. Dissertação (Mestrado) - Universidade de Brasília, Programa de Pós - graduação em Educação, Brasília, 2012.

MIGLIEVICH-RIBEIRO, Adélia M. Reflexões sobre a utopia necessária e a universidade brasileira a partir de Darcy Ribeiro e Anísio Teixeira. In: VILLAR, José Luís; CASTIONI, Remi (Org.). O projeto da UnB e a educação brasileira. Brasília: Verbena, 2012, p. 27-59.

MINISTÉRIO DA EDUCAÇÃO. Website. e-MEC. Disponível em: <http://portal.mec.gov.br/e-mec-sp-257584288>. Acesso em: 15 jan. 2015.

MINISTÉRIO DAS RELAÇÕES EXTERIORES. Website. Denominações das instituições de ensino superior. Disponível em: <http://www.dce.mre.gov.br/nomenclatura_cursos.html>. Acesso em: 10 jan. 2016.

MINTO, Lalo Watanabe. Educação superior no PNE (2014- 2024): apontamentos sobre as relações público - privado. In.: $37^{\mathrm{a}}$ REUNIÃO DA ANPED. 37., 2015, Florianópolis. Anais... Florianópolis: UFSC, 2015. p. 1 - 18. v. 1.

MORAN, José Manuel. A educação superior a distância no Brasil. In: SOARES, Maria Susana Arrosa. (Org). A educação superior no Brasil. Porto Alegre: UNESCO, 2002, p. 273-301. 
MOROSINI, Marília Costa. Qualidade da educação superior e contextos emergentes. Avaliação. Campinas, v. 19, n. 2, p. 385-405, jul. 2014. Disponível em: <http://www.scielo.br/pdf/aval/v19n2/a07v19n2.pdf>. Acesso em: 2 jul. 2015.

FRANCO, Maria Estela. Políticas públicas de qualidade universitária e construção de espaços de participação. In: 25 ${ }^{\mathrm{a}}$ REUNIÃO ANUAL DA ANPED, 25, 2002, Caxambu. Anais... Caxambu: UERJ, 2002. p. 1 - 17. v. 1.

MULLER, Pierre. SUREL, Yves. A análise das políticas públicas. Pelotas: Educat, 2002.

NASCIMENTO, Marlúcio Tavares. A institucionalização da auto-avaliação na Universidade Estadual de Goiás (UEG): avanços, limites e desafios. Dissertação (Mestrado) - Universidade Federal de Goiás, Programa de Pós - graduação em Educação, Goiânia, 2008.

NEAVE, Guy. On the cultivation of quality, efficiency and enterprise: An overview of recent trends in higher education in Western Europe, 1986-1988. European Journal of Education, v. 23, n. 1-2, p. 7-23, 1988. Disponível em: <http://www.jstor.org/stable/ 1502961 ?seq=1\#page_scan_tab_contents>. Acesso em: 28 nov. 2015.

NOGUEIRA, Vera Maria Ribeiro. Estado de Bem-Estar Social - origens e desenvolvimento. Katálysis, v. 1, n. 5, p. 89-103, jul/dez. 2001. Disponível em: < https://periodicos.ufsc.br/index.php/katalysis/article/viewFile/5738/5260>. Acesso em: 13 ago. 2014.

NUNES, Clarice. Anísio Teixeira entre nós: a defesa da educação como direito de todos. Educação e Sociedade, ano XXI, n.73, dez. 2000. Disponível em: < http://www.scielo.br/pdf/es/v21n73/4203.pdf>. Acesso em: 20 jan. 2016.

NUNES, Edson de Oliveira; BARROSO, Helena Maria; FERNANDES, Ivanildo Ramos. Do CNE ao CNE: 80 anos de política regulatória. Observatório Universitário. Databrasil Ensino e Pesquisa. Documento de Trabalho, n. 99, nov. 2011. Disponível em: <http://www.observatoriouniversitario.org.br/documentos_de_trabalho/documentos_de_trabal ho_99.pdf>. Acesso em: 10 fev. 2016.

ORGANIZAÇÃO DAS NAÇÕES UNIDAS PARA A EDUCAÇÃO, A CIÊNCIA E A CULTURA. La Educación Superior em el Siglo XXI: visión y acción. Paris: Unesco, 1998. Disponível em: < http://unesdoc.unesco.org/images/0011/001163/116345s.pdf >. Acesso em: 13 fev. 2014. 
Relatório de monitoramento global de EPT 2005: educação para todos, imperativo para a qualidade, São Paulo: Moderna, 2005. Disponível em: < http://unesdoc.unesco.org/images/0013/001390/139079por.pdf>. Acesso em: 13 fev. 2014.

ORGANISATION ECONOMIC CO-OPERATION AND DEVELOPMENT (OECD). Quality and internationalisation in higher education: Programme on Institutional Management in Higher Education-IMHE. Paris: OECD, 1999. Disponível em: < http://www.voced.edu.au/content/ngv\%3A59001>. Acesso em: 13 mai. 2015.

OLIVEIRA, Ana Paula de Matos; SOUZA, Valdinei Costa; SOUSA, José Vieira de; TAVARES, Érica Pâmela Goulart. Políticas de avaliação e regulação da educação superior brasileira: percepções de coordenadores de licenciaturas no Distrito Federal. Avaliação, v. 18, n. 3, p. 629-655, 2013. Disponível em: <http://periodicos.uniso.br /ojs/index.php?journal=avaliacao\&page=article\&op=view\&path[]=1660>. Acesso em: 2 abr. 2014.

OLIVEIRA, Hélio Ázara de. Considerações sobre a dialética do abstrato e do concreto na circulação simples de O Capital. Cardernos Cemarx, n. 6, p. 29-44, 2009. Disponível em: < http://www.ifch.unicamp.br/ojs/index.php/cemarx/article/view/1087>. Acesso em: 20 fev. 2016.

OLIVEIRA, João Ferreira de; FONSECA, Marília; AMARAL, Nelson Cardoso. Avaliação, desenvolvimento institucional e qualidade do trabalho acadêmico. Educar, Curitiba, n. 28, p. 71-87, jul/dez. 2006. Disponível em: 〈http://www.scielo.br/pdf/ er/n28/a06n28.pdf〉. Acesso em: 3 mar. 2014.

OLIVEIRA, Karine Rios de. Nós, a gente e o clítico se como estratégias de indeterminação do sujeito no Português. 2006. 173f. Dissertação (Mestrado) - Universidade Federal de Uberlândia, Programa de Pós Graduação em Linguística, Uberlândia, 2006.

OLIVEN, Arabela Campos. Histórico da educação superior no Brasil. In: SOARES, Maria Susana Arrosa. (Org). A educação superior no Brasil. Porto Alegre: UNESCO, 2002, p. 2438.

OTTONE, Ernesto. Educação e conhecimento: eixo da transformação produtiva com equidade (uma visão sintética). Tradução de Emiliano G. Waiselfisz. Brasília: MEC/INEP, 1993.

PAULO NETTO, José. Introdução ao estudo do método de Marx. São Paulo: Expressão Popular, 2011. 
PIRSIG, Robert. M. Zen and the Art of Motorcycle Maintenance: An inquiry into values. Nova York: Morrow, 1974.

POLIDORI, Marlis Morosini. Políticas de avaliação da educação superior brasileira: Provão, Sinaes, IDD, CPC, IGC e...outros índices. Avaliação, Campinas, v. 14, n. 2, p. 439-452, jul. 2009. Disponível em: <http://www.scielo.br/pdf/aval/v14n2/ a09v14n2.pdf>. Acesso em: 24 mar. 2014.

MARINHO-ARAUJO, Claysi M.; BARREYRO, Gladys Beatriz. SINAES: Perspectivas e desafios na avaliação da educação superior brasileira. Ensaio: avaliação e políticas públicas em educação, Rio de Janeiro, v.14, n.53, p. 425-436, out/dez. 2006. Disponível em: < http://www.scielo.br/pdf/ensaio/v14n53/a02v1453.pdf>. Disponível em: 20 abr. 2014.

RETTL, Ana Maria de Mattos; MORAES, Mário Cesar Barreto; CASTRO, Maria Cristina Lima de. Políticas de Avaliação da Educação Superior. Educação e Realidade, Porto Alegre, v. 36, n.1, p. 253-278, jan/abr. 2011. Disponível em: < http://seer.ufrgs.br/educacaoerealidade/article/view/9545>. Acesso em: 12 jun. 2015.

POLITZER, Georges; BESSE, Guy; CAVEING, Maurice. Princípios fundamentais de filosofia. São Paulo: Hemus, 1970.

QUEIROZ, Kelli Consuêlo Almeida de Lima. Eu avalio, tu avalias, nós nos autoavaliamos? - uma experiência proposta pelo Sinaes. Brasília: Autores Associados, 2011.

Eu avalio, tu avalias, nós nos auto-avaliamos? - A experiência da Unidade Universitária de Ciências Sócio-Econômicas e Humanas - UnUCSEH/UEG com a autoavaliação proposta pelo SINAES. 2008. 176f. Dissertação (Mestrado) - Universidade de Brasília, Programa de Pós - graduação em Educação, Brasília, 2008.

Reconhecimento de cursos de graduação em instituições privadas no marco do Sinaes: avaliação, regulação e acomodação. 2014. 315f. Tese (Doutorado) - Universidade de Brasília, Programa de Pós - graduação em Educação, Brasília, 2014.

VIEIRA, Leonardo; RANGEL, Andrea. Brasil é o penúltimo em ranking internacional de investimento por aluno. O Globo, Rio de Janeiro, 9 set. 2014, p. 1. Disponível em: <http://oglobo.globo.com/sociedade/educacao/brasil-o-penultimo-em-ranking-internacionalde-investimento-por-aluno-13873118>. Acesso em: 10 dez. 2014.

RIBEIRO, Elisa Antonia. As atuais políticas públicas de avaliação para a educação superior e os impactos na configuração do trabalho docente. Avaliação, Campinas, SP. v. 17, n. 2, p. 
299-316, jul. 2012. Disponível em: <http://www.scielo.br/pdf/ aval/v17n2/02.pdf>. Acesso em: 12 dez. 2015.

O processo de autoavaliação institucional proposto no sistema nacional de avaliação da educação superior (Sinaes) para as instituições públicas e privadas. 2010. 320f. Tese (Doutorado) - Universidade Federal de Uberlândia, Programa de Pós -graduação em Educação, Uberlândia, 2010.

RIBEIRO, Jorge Luiz Lordêlo de Sales. Avaliação das universidades brasileiras: as possibilidades de avaliar e as dificuldades de ser avaliado. Avaliação, Campinas, v. 16, n. 1, p. 57-71, 2011. Disponível em: <http://www.scielo.br/pdf/aval/v16n1/ v16n1a04.pdf>. Acesso em: 21 nov. 2015.

RISTOFF, Dilvo I. O Sinaes e seus desafios. Avaliação: Campinas, v. 9, n. 1, p. 179-183, mar. 2004. Disponível em: <http://periodicos.uniso.br/ojs/index.php?journal= avaliacao\&page=article\&op=view\&path[]=1262\&path[]=1252>. Acesso em: 12 abr. 2014.

RODRIGUES, José. Os empresários e a educação superior. Campinas: Autores Associados, 2007.

RODRIGUES, Maria Marta do Couto Pereira. Política do Sinaes: significado e efeitos em IES privadas de Minas Gerais. 2015. 353f. Tese (Doutorado) - Universidade de Brasília, Programa de Pós-graduação em Educação, Brasília, 2015.

ROSAS, Paulo. Universidade brasileira: frustrações, expectativas e esperanças. Educação Brasileira, Brasília, v. 7, n. 15, 1985 apud. ROTHEN, José Carlos; BARREYRO, Gladys Beatriz. Para uma história da avaliação da educação superior brasileira: análise dos documentos do PARU, CNRES, GERES e PAIUB. Avaliação, Campinas, v.13, n.1, p.131152, mar. 2008. Disponível em: < http://www.scielo.br/pdf/aval/v13n1/a08v13n1.pdf>. Acesso em: 10 dez. 2014.

ROTHEN, José Carlos; BARREYRO, Gladys Beatriz. Para uma história da avaliação da educação superior brasileira: análise dos documentos do PARU, CNRES, GERES e PAIUB. Avaliação, Campinas, v.13, n.1, p.131-152, mar. 2008. Disponível em: < http://www.scielo.br/pdf/aval/v13n1/a08v13n1.pdf>. Acesso em: 10 dez. 2014.

SANDER, Benno. Gestão da educação na América Latina: construção e reconstrução do conhecimento. Campinas: Autores Associados, 1995.

SANTOS, Fernanda Pereira; REIS, Giliarde Alves dos; BARROA FILHO, Carlito José; BARBOSA, Ana Carina Ferreira. A Abstenção dos Estudantes nas Autoavaliações 
Institucionais. In: SEMINÁRIOS REGIONAIS SOBRE AUTOAVALIAÇÃO INSTITUCIONAL E COMISSÕES PRÓPRIAS DE AVALIAÇÃO (CPA), 1., 2013, Brasília. Anais... Brasília: Inep, 2013. p. 1 - 9. v.1.

SAKAMOTO, Rosa Maria dos Santos Manso. A acreditação no sistema federal de ensino superior e seus reflexos na rotina institucional da UFJF. 2012. 138f. Dissertação (Mestrado) - Universidade Federal de Juiz de Fora, Programa de Mestrado Profissional em Gestão e Avaliação da Educação Pública, Juiz de Fora, 2012.

SAVIANI, Dermeval. A expansão do ensino superior no Brasil: Mudanças e continuidades. Poíesis Pedagógica, Goiânia, v.8, n. 2, p.4-17, ago/dez. 2010. Disponível em: $<$ http://revistas.ufg.emnuvens.com.br/poiesis/article/view/14035/8876>. Acesso em: $12 \mathrm{dez}$. 2015.

SÉCCA, Rodrigues Ximenes; LEAL, Rodrigo Mendes. Análise do setor de ensino privado no Brasil. BNDES Setorial, Rio de Janeiro, v. 30, p. 103-156, set. 2009. Disponível em: <http://www.bndes.gov.br/SiteBNDES/export/sites/default/bndes_pt/Galerias/Arquivos/conhe cimento/bnset/set3003.pdf>. Acesso em: 20 mai. 2014.

SGUISSARDI, Valdemar. Modelo de expansão da educação superior no Brasil: predomínio privado/mercantil e desafios para a regulação e a formação universitária. Educação e Sociedade, Campinas, v. 29, n. 105, p. 991-1022, set/dez. 2008. Disponível em: <http://www.scielo.br/pdf/es/v29n105/v29n105a04>. Acesso em: 25 abr. 2014.

Regulação estatal e desafios da expansão mercantil da educação superior. Educação e Sociedade, Campinas, v. 34, n. 124, p. 943-960, jul/set. 2013. Disponível em: <http://www.redalyc.org/articulo.oa?id=87328534015>. Acesso em: 22 jan. 2016.

SCHWARTZMAN, J.; SCHWARTZMAN, S. O ensino superior privado como setor econômico. BNDES Setorial, Rio de Janeiro, p. 1-29, 2002. Disponível em: < http://www.schwartzman.org.br/simon/pdf/suppriv.pdf>. Acesso em: 17 set. 2014.

SILVA, Ariane Franco Lopes de; MARTINS, Maria Angela Rodrigues; ABDALLA, Maria de Fátima Barbosa. Políticas de avaliação universitária: o que pensam os professores sobre o ENADE. Revista Brasileira de Política e Administração da Educação - RBPAE, v. 30, n. 1, p. 41-61, jan/abr. 2014. Disponível em: < http://www.seer.ufrgs.br/rbpae/article/download/50012/31321>. Acesso em 7 abr. 2015.

SILVA, Iara Augusta da; FERRO, Olga Maria dos Reis; ARRUDA, Elcia Esnarriaga de. O trabalho do professor em face da organização do curso de Pedagogia no Centro Universitário de Campo Grande/MS: as possibilidades e os limites da utilização dos textos clássicos no 
ensino superior. In: 33ª REUNIÃO DA ANPED. 33., 2010, Caxambu. Anais... Caxambu: UERJ, 2010. p. 1 - 16. v.1.

SILVA, Luiz Marcos de Oliveira; MATTOS, Fernando Augusto Mansor. Welfare State e emprego em saúde nos países avançados desde o Pós-Segunda Guerra Mundial. Revista de Economia Política, v. 29, n. 3, p. 135-152, jul/set. 2009. Disponível em: < http://www.rep.org.br/PDF/115-8.PDF>. Acesso em: 12 abr. 2014.

SOARES NETO, Joaquim; BELLONI, José Angelo; AIRES, Carmenisia Jacobina; WALTER, Maria Ines Machado Telles; FALQUETO, Júnia. Plano de Autoavaliação da Universidade de Brasília: proposta metodológica e estratégica da CPA-UnB para avaliação institucional. In: SEMINÁRIOS REGIONAIS SOBRE AUTOAVALIAÇÃ̃O INSTITUCIONAL E COMISSÕES PRÓPRIAS DE AVALIAÇÃO (CPA), 1., 2013, Brasília. Anais... Brasília: Inep, 2013. p. 1 - 15. v.1.

SOUSA, Clarilza Prado de; MARCONDES, Anamérica Prado; ACOSTA, Sandra Ferreira. Auto-avaliação institucional: uma discussão em processo. Estudos em Avaliação Educacional, v. 19, n. 39, jan./abr. 2008. Disponível em: < http://www.fcc.org.br/pesquisa/publicacoes/eae/arquivos/1417/1417.pdf >. Acesso em: 28 ago. 2015.

SOUSA, José Vieira de. Educação superior no Distrito Federal: consensos, conflitos e transformações na configuração de um campo. Brasília: Liber Livro, 2013.

O Ensino superior privado no Distrito Federal: uma análise de sua recente expansão (1995-2001). 2003. 279f. Tese (Doutorado) - Universidade de Brasília, Programa de Pós - Graduação em Sociologia, Brasília, 2003.

Qualidade na educação superior: lugar e sentido na relação público-privado. Caderno Cedes, Campinas, vol. 29, n. 78, p. 242-256, maio/ago. 2009. Disponível em: <http://www.scielo.br/pdf/ccedes/v29n78/v29n78a07.pdf>. Acesso em: 15 dez. 2014.

Restrição do público e estímulo à iniciativa privada: tendência histórica no ensino superior brasileiro. In: SILVA, Maria Abádia da; SILVA, Ronalda Barreto. (Org.). A ideia de universidade: rumos e desafios. Brasília: Líber, 2006. p. 139-178.

Marketing produzido e imagens projetadas para a comunidade pelas instituições privadas de ensino superior no Distrito Federal: conflito e cumplicidade. In: $27^{\mathrm{a}}$ REUNIÃO DA ANPED. 27., 2004, Caxambu. Anais... Caxambu: UERJ, 2004. p. 1 - 15. v.1. 
Fernandes, Ivanildo Ramos. Regulação excessiva e avaliação de exceção: uma análise sobre os fundamentos técnicos e legais da expansão dos cursos de Administração, Enfermagem, Pedagogia e Engenharia Civil entre 2004 e 2014. In: XXIII SEMINÁRIO NACIONAL DA REDE UNIVERSITAS/BR. POLÍTICAS DE EDUCAÇÃO SUPERIOR NO BRASIL: A EXPANSÃO PRIVADO - MERCANTIL EM QUESTÃO, 23., 2015, Belém. Anais... Belém: UFPA, 2015. p. 436 - 451. v. 1.

- GONÇALVES, Lukelly Fernanda Amaral. Qualidade na educação superior brasileira: uma análise da temática em dissertações e teses produzidas pós-Sinaes. In: XII ENCONTRO DE PESQUISA EM EDUCAÇÃO CENTRO-OESTE, 12., 2014, Goiânia. Anais... Goiânia: PUC-GO, 2014. p. 1-13. v. 1.

SOUZA, Fábio Silva de; FEITOSA, Maria Lenir Oran. Metodologia do trabalho científico. Manaus: ESBAM, 2012.

SOUZA, Regina Célia Stroligo de; MÉXAS, Mirian Picinini. A responsabilidade social sob a perspectiva do Sinaes: um estudo de caso em uma instituição federal de ensino. In: X Congresso Nacional de Escelência em Gestão. 2014, Rio de Janeiro. Anais... Rio de Janeiro: FIRJAN, 2014.

SOUZA, Thaís Godoi de; OLIVEIRA, Caroline Mari de. A produção do conhecimento em educação: reflexões de uma análises dialética. In: IX SEMINÁRIO NACIONAL DE ESTUDOS E PESQUISAS: HISTÓRIA, SOCIEDADE E EDUCAÇÃO NO BRASIL, 9., 2012, João Pessoa. Anais... João Pessoa: UFPB, 2012. p. 3.752 - 3.765. v. 1.

SCRIVEN, Michael. Evaluation thesaurus. 4. ed. Newbury Park: Sage, 1991.

TAKAHASHI, Fábio. Universidades reprovadas não são fiscalizadas desde 95. Folha de S. Paulo, São Paulo, 13 set. 2008. p. 1. Disponível em: <http://www1.folha.uol.com.br/paywall/login.shtml?http://www1.folha.uol.com.br/fsp/ cotidian/ff1309200801.htm>. Acesso em: 10 ago. 2015.

TAVARES, Maria das Graças Medeiros; MENEGHEL, Stela Maria; ROBL, Fabiane; BARREYRO, Gladys Beatriz; ROTHEN, José Carlos; SOUSA, José Vieira. Políticas de expansão da educação superior no Brasil pós-LDB/96 - desafios para a avaliação. Revista da Faculdade de Educação da UFG, Goiânia, v. 36, n. 1, p. 81-99, jan/jun. 2011. Disponível em: 〈http://revistas.ufg.emnuvens.com.br/interacao/article/view /15029>. Acesso em: 20 out. 2015.

TEIXEIRA, Anísio. Educação e universidade. In.: FÁVERO, Maria de Lourdes Albuquerque.; BRITTO, Jader de Medeiros. (Org.). Anísio Teixeira: educação e universidade. 2. ed. Rio de Janeiro: Editora UFRJ, 2010. 
TEIXEIRA, Francisco. J. S. Neoliberalismo e Reestruturação Produtiva: as novas determinações do mundo do trabalho. São Paulo: Cortez, 1996.

TEIXEIRA JÚNIOR, Paulo Roberto. Os efeitos do Sinaes no curso de Administração. 130f. Dissertação (Mestrado) - Pontifícia Universidade Católica de Campinas, Programa de Pós - Graduação em Educação, Campinas, 2015.

TENÓRIO, Robinson Moreira; ARGOLLO, Rivailda Silveira Nunes de. Sinaes na perspectiva de membros da CPA: implantação, condução e avaliação. In: LORDÊLO, José Albertino Carvalho; DAZZANI, Maria Virgínea. (Org.). Avaliação educacional: desatando e reatando nós. [online]. Salvador: EDUFBA, 2009. p. 103-122.

TRIGUEIRO, Michelangelo Giotto Santoro. Governo e gestão da educação superior no Brasil. In: SOARES, Maria Susana Arrosa. (Org). A educação superior no Brasil. Porto Alegre: UNESCO, 2002.

TRIGUEIRO MENDES, Durmeval. A Expansão do ensino superior no Brasil. Documenta, Brasília, n. 91, p. 26-66, set. 1968.

UNIVERSIDADE DE BRASÍLIA. Resolução do Conselho Universitário n.0014/2016. Nomeia integrantes da Comissão Própria de Avaliação. Universidade de Brasília, Brasília, DF, 15 fev. 2016a.

. Resolução do Conselho Universitário n.0023/2016. Substitui integrante da Comissão Própria de Avaliação. Universidade de Brasília, Brasília, DF, 03 mar. $2016 b$.

Resolução do Conselho Universitário n.0332/2015. Substitui membros da Comissão Própria de Avaliação. Universidade de Brasília, Brasília, DF, 26 mar. 2015a.

. Resolução do Conselho Universitário n.0971/2015. Substitui membros da Comissão Própria de Avaliação. Universidade de Brasília, Brasília, DF, 31 ago. 2015 b.

. Resolução do Conselho Universitário n.0147/2015. Substitui membros da Comissão Própria de Avaliação. Universidade de Brasília, Brasília, DF, 14 dez. 2015c.

Resolução do Conselho Universitário n.1124/2014. Substitui membros da Comissão Própria de Avaliação. Universidade de Brasília, Brasília, DF, 12 ago. 2014.

Resolução do Conselho Universitário n. 0031/2013. Institui no âmbito da Universidade de Brasília a Comissão Própria de Avaliação. Universidade de Brasília, Brasília, DF, 24 set. 2013a. 
Resolução do Conselho Universitário n. 0883/2013. Nomeia os membros da Comissão Própria de Avaliação. Universidade de Brasília, Brasília, DF, 14 out. 2013b.

Plano de Desenvolvimento Institucional - PDI. Brasília: UnB, 2014. Disponível em: <http://www.dpo.unb.br/documentos/PDI/PDI_2014-2017.pdf>. Acesso em: 15 jan. 2016.

Relatório de autoavaliação institucional 2015. Brasília: UnB, 2016. Disponível em: < www.cpa.unb.br>. Acesso em 24 mai. 2016.

Relatório de autoavaliação institucional 2014. Brasília: UnB, 2015. Disponível em: < www.cpa.unb.br>. Acesso em 10 out. 2015.

Website. Repositório institucional da UnB. Disponível em: < http://repositorio.unb.br/>. Acesso em 15 jan. 2016.

VERHINE, Robert E.; A autoavaliação, os seminários regionais e a implementação do Sinaes: reflexões e perspectivas fundamentadas na experiência da Conaes. In: SEMINÁRIOS REGIONAIS SOBRE AUTOAVALIAÇÃO INSTITUCIONAL E COMISSÕES PRÓPRIAS DE AVALIAÇÃO (CPA), 2013, Anais... 2013. p.46-59. v.1.

DANTAS, Lys Maria Vinhaes. Avaliação da Educação Superior no Brasil: do Provão ao ENADE. Documento Preparado para o Banco Mundial. Dez. 2005. Disponível em: $<$ http://www.isp.ufba.br/avalia\%C3\%A7\%C3\%A3o\%20da\%20Ed\%20Superior\%20do\%20Pr ovao\%20ao\%20ENADE.pdf>. Acesso em: 25 mai. 2014.

MONTEIRO DE FREITAS, Antônio Alberto da Silva. A avaliação da educação superior: modalidades e tendências no cenário internacional. Revista Ensino Superior Unicamp, v.3, n.7, p.16-39, 2012. Disponível em: < https://www.revistaensinosuperior.gr.unicamp.br/edicoes/ed07_outubro2012/ARTIGO_PRIN CIPAL.pdf>. Acesso em: 10 jan. 2016.

VIANNA, Cleverson Tabajara. Rendimientos académicos y eficacia social de la Universidad. In: XIII COLÓQUIO DE GESTIÓN UNIVERSITÁRIA EN AMÉRICAS, 2013, Anais... 2013. p. 1-19. v.1.

VIEIRA, Regina Lúcia Bastos. Política pública de avaliação da educação superior - o SINAES na universidade pública estadual: o caso da Universidade do Estado da Bahia UNEB. 163f. Dissertação (Mestrado) - Universidade Católica de Salvador, Programa de PósGraduação em Políticas Sociais e Cidadania, Salvador, 2008. 
YANNOULAS, Silvia Cristina; SOUZA, Camila Rosa Fernandes de; ASSIS, Samuel Gabriel. Políticas educacionais e o estado avaliador: uma relação conflitante. Revista Sociedade em Debate, Pelotas, v. 15, n. 2, p. 55-67, jul/dez. 2009. Disponível em: < http://revistas.ucpel.edu.br/index.php/rsd/article/view/351>. Acesso em: 24 set. 2014.

YIN, Robert K. Estudo de caso: planejamento e métodos. 2. ed. Porto Alegre: Bookman, 2001.

ZAINKO, Maria Amelia Sabrag. Avaliação da educação superior no Brasil: processo de construção histórica. Avaliação, Campinas, v. 13, n. 3, nov. 2008. Disponível em: < http://www.scielo.br/pdf/aval/v13n3/12.pdf>. Acesso em: 12 nov. 2014. 


\section{APÊNDICES \\ Apêndice A - Carta de apresentação ao representante da IES \\ UNIVERSIDADE DE BRASÍLIA - UnB PROGRAMA DE PÓS-GRADUAÇÃO EM EDUCAÇÃO - PPGE}

Brasília, de de 2016.

Senhor (a)

Como aluna de pós-graduação do Mestrado em Educação da Universidade de Brasília (UnB), estou pesquisando, sob a orientação do professor Dr. José Vieira de Sousa, a autoavaliação institucional a partir dos moldes da política pública do Sistema Nacional de Avaliação da Educação Superior (Sinaes). Objetiva-se, dentro dessa temática, compreender a forma como as dimensões do Sinaes para a autoavaliação são trabalhadas nos relatórios e na dinâmica da Comissão Própria de Avaliação (CPA) no contexto da Universidade de Brasília precursora desse processo avaliativo no país.

Para tanto, faz parte do método dessa pesquisa a compreensão histórica da autoavaliação dessa instituição, bem como a realização de entrevistas semiestruturadas com representantes de cada segmento (docentes, discentes, técnicos administrativos e sociedade civil organizada) da CPA da UnB. Nesse sentido, solicitamos sua autorização para a continuidade desta pesquisa e asseguramos que o momento de coleta de dados não será invasivo, nem realizado em momentos inapropriados.

A pesquisadora, representando o Programa de Pós-graduação em Educação da Universidade de Brasília, compromete-se com todos os procedimentos éticos referentes à pesquisa. Em nenhum momento as informações prestadas serão utilizadas com outra finalidade que não seja acadêmica, e o anonimato dos entrevistados será garantido em todos os procedimentos de análise e divulgação dos resultados.

Assim, por meio desta carta, solicitamos a colaboração da Universidade e colocamonos à disposição para eventuais esclarecimentos.

Atenciosamente,

Lukelly Fernanda Amaral Gonçalves

Mestrado em Educação

Programa de Pós-Graduação em Educação da Universidade de Brasília

Contatos: E-mail: lukellyf@ hotmail.com Fone: (61) 83001783 


\title{
Apêndice B - Carta de apresentação ao membro da CPA \\ UNIVERSIDADE DE BRASÍLIA - UnB PROGRAMA DE PÓS-GRADUAÇÃO EM EDUCAÇÃO - PPGE
}

\author{
Brasília, de \\ de 2016.
}

Senhor(a)

Como aluna de pós-graduação do Mestrado em Educação da Universidade de Brasília (UnB), estou pesquisando, sob a orientação do professor Dr. José Vieira de Sousa, a autoavaliação institucional a partir dos moldes da política pública do Sistema Nacional de Avaliação da Educação Superior (Sinaes). Objetiva-se, dentro dessa temática, compreender a forma como as dimensões do Sinaes para a autoavaliação são trabalhadas nos relatórios e na dinâmica da Comissão Própria de Avaliação (CPA) no contexto da Universidade de Brasília precursora desse processo avaliativo no país.

Para tanto, faz parte do método dessa pesquisa a compreensão histórica da autoavaliação dessa instituição, bem como a realização de entrevistas semiestruturadas com representantes de cada segmento (docentes, discentes, técnicos administrativos e sociedade civil organizada) da CPA da UnB. Por conseguinte, é necessária a realização de uma entrevista individual com V. Sa., razão pela qual solicito sua colaboração no sentido de conceder aproximadamente 30 (trinta) minutos de sua agenda de trabalho para a realização da mesma.

Por oportuno, informo que, com a sua permissão, a entrevista será gravada, visando sua posterior transcrição, a qual colaborará com a base de dados do estudo. Todo o material coletado será utilizado somente na pesquisa e a participação de V. As. não será relacionada com trechos de depoimentos que possam implicar a identificação de sua identidade.

Ressaltamos que a participação nessa pesquisa é voluntária e poderá haver a desistência a qualquer momento, não havendo previsão de gastos ou remuneração. Em nenhum momento as informações prestadas serão utilizadas com outra finalidade que não seja acadêmica, e o anonimato será garantido em todos os procedimentos de análise e divulgação dos resultados.

Representando o Programa de Pós-Graduação em Educação da Universidade de Brasília a pesquisadora compromete-se com todos os procedimentos éticos referentes à pesquisa e ressalta a importância de sua valiosa colaboração para o estudo.

Assim, por meio desta carta, solicitamos a sua colaboração e colocamo-nos à disposição para eventuais esclarecimentos.

Atenciosamente,

Lukelly Fernanda Amaral Gonçalves

Faculdade de Educação / Universidade de Brasília

Programa de Pós-Graduação em Educação

Contatos: E-mail: lukellyf@ hotmail.com Fone: (61) 83001783 
Apêndice C - Termo de consentimento livre e esclarecido ao representante da IES

\author{
UNIVERSIDADE DE BRASÍLIA - UnB \\ PROGRAMA DE PÓS-GRADUAÇÃO EM EDUCAÇÃO - PPGE
}

$\mathrm{Eu}$,

abaixo

assinado, declaro que fui informado(a) por Lukelly Fernanda Amaral Gonçalves acerca de sua pesquisa, titulada "A autoavaliação na Universidade de Brasília: entre a proposta do Sinaes e os sinaes da prática", a qual está vinculada ao Programa de Pós-Graduação em Educação da Universidade de Brasília.

Declaro que fui informado(a) que o objetivo do estudo é compreender como o que o Sinaes prevê para a autoavaliação é ressignificado na prática da Universidade de Brasília; e que as informações colhidas pela pesquisadora não serão usadas em prejuízo da(s) pessoa(s) envolvida(s) e/ou da instituição.

Também declaro que autorizo a pesquisadora a dar continuidade à pesquisa para que a mesma compreenda historicamente o contexto da autoavaliação da Universidade de Brasília, o que prevê a realização da gravação de entrevistas com os membros da Comissão Própria de Avaliação dessa instituição.

Por fim, afirmo estar ciente de que a participação desta instituição no estudo não prevê gastos ou remuneração. E, por estar de pleno acordo com os termos ajustados e mencionados neste documento, assinamos o presente instrumento em duas (2) vias de igual teor e forma, para um só efeito.

Brasília/DF, de de 2016. 
Apêndice D - Termo de consentimento livre e esclarecido para gravação de entrevistas com (i) membros da CPA da UnB; (ii) pesquisadores da área de avaliação; (iii) membro da Conaes e (iv) funcionário da Daes/Inep

\section{UNIVERSIDADE DE BRASÍLIA - UnB PROGRAMA DE PÓS-GRADUAÇÃO EM EDUCAÇÃO - PPGE}

$\mathrm{Eu}$, abaixo assinado, declaro que fui informado(a) por Lukelly Fernanda Amaral Gonçalves acerca de sua pesquisa, titulada "A autoavaliação na Universidade de Brasília: entre a proposta do Sinaes e os sinaes da prática", a qual está vinculada ao Programa de Pós-Graduação em Educação da Universidade de Brasília.

Declaro que fui informado(a) que o objetivo do estudo é compreender como o que o Sinaes prevê para a autoavaliação é ressignificado na prática da Universidade de Brasília.

Também declaro que autorizo a gravação da entrevista e a utilização de sua transcrição para a pesquisa, desde que minha identidade permaneça resguardada e que meus depoimentos não sejam usados em prejuízo da(s) pessoa(s) envolvida(s) e/ou da instituição.

Estou ciente de que minha participação não é obrigatória, não gera remuneração e, ainda, que posso desistir antes ou durante a realização da entrevista, caso me sinta constrangido(a).

Por fim, afirmo saber que a pesquisadora manterá em caráter confidencial todas as respostas que comprometam a minha privacidade; e, por estar de pleno acordo com os termos ajustados e mencionados neste documento, assinamos o presente instrumento em duas (2) vias de igual teor e forma, para um só efeito.

Brasília/DF, de de 2016 . 
Apêndice E - Roteiro de entrevista com os membros das CPA

\section{IDENTIFICAÇÃO:}

Nome do membro da Comissão Própria de Avaliação:

Vinculo Institucional:

Período em que atua como membro da Comissão Própria de Avaliação:

Trajetória acadêmica e profissional:

\section{PERGUNTAS:}

\section{BLOCO 1: OS RELATÓRIOS DE AUTOAVALIAÇÃO E O ATENDIMENTO ÀS} DIMENSÕES DA POLÍTICA DO SINAES

1. Quais os procedimentos utilizados pela Comissão Própria de Avaliação para coordenar a autoavaliação na Universidade de Brasília?

2. Em que medida o(a) senhor(a) considera que os relatórios de avaliação produzidos sob a coordenação da Comissão Própria de Avaliação atendem as dimensões do Sistema Nacional de Avaliação da Educação Superior?

3. Em sua avaliação, a Comissão Própria de Avaliação tem alguma dificuldade para coordenar a autoavaliação?

\section{BLOCO 2: O USO DOS RESULTADOS DA AUTOAVALIAÇÃO PELA GESTÃO DA UNIVERSIDADE}

1. De que maneira a equipe de gestão da Universidade de Brasília acompanha o ciclo avaliativo da autoavaliação?

2. Na sua avaliação, para que serve o relatório de autoavaliação na Universidade de Brasília?

3. $\mathrm{O}(\mathrm{A})$ senhor(a) saberia informar alguma ação realizada pela equipe de gestão da Universidade de Brasília que tenha sido realizada a partir dos resultados da autoavaliação?

\section{BLOCO 3: O SIGNIFICADO ATRIBUÍDO À AUTOAVALIAÇÃO}

1. Qual a sua análise acerca da autoavaliação na sua Universidade de Brasília?

2. Como o(a) senhor(a) avaliaria a sua contribuição como membro da Comissão Própria de Avaliação da Universidade de Brasília?

3. Na sua percepção, como a comunidade acadêmica percebe a autoavaliação?

Data da realização:

Hora de início:

Hora de término:

Local:

Clima da entrevista:

Aspectos que merecem aprofundamento e/ou utilização de outros instrumentos: 


\section{Apêndice $\mathbf{F}$ - Roteiro de entrevista com pesquisador da área}

\section{IDENTIFICAÇÃO:}

Nome do membro da Comissão Própria de Avaliação:

Vinculo Institucional:

Período em que atua como membro da Comissão Própria de Avaliação:

Trajetória acadêmica e profissional:

\section{PERGUNTAS:}

\section{BLOCO 1: OS RELATÓRIOS DE AUTOAVALIAÇÃO E O ATENDIMENTO ÀS DIMENSÕES DA POLÍTICA DO SINAES}

1. Quais os procedimentos que se espera que uma Comissão Própria de Avaliação realize para coordenar a autoavaliação?

2. A partir da sua experiência, como pesquisador(a) da temática da autoavaliação, em que medida o senhor(a) considera que os relatórios de avaliação produzidos atendem as dimensões do Sistema Nacional de Avaliação da Educação Superior?

3. Em sua avaliação, as Comissões Próprias de Avaliação enfrentam dificuldades para coordenar a autoavaliação?

\section{BLOCO 2: EXPECTATIVAS PARA O USO DOS RESULTADOS DA AUTOAVALIAÇÃO PELA GESTÃO DAS UNIVERSIDADES}

1. Qual a maneira esperada para que a equipe de gestão de uma instituição de educação superior acompanhe o ciclo avaliativo da autoavaliação?

2. Na sua avaliação, para que vem servindo, na prática, o relatório de autoavaliação?

3. $\mathrm{O}(\mathrm{A})$ senhor(a) saberia informar experiências nacionais exitosas relacionadas ao uso dos resultados da autoavaliação?

\section{BLOCO 3: O SIGNIFICADO ATRIBUÍDO À AUTOAVALIAÇÃO}

1. Qual a sua análise acerca do papel da autoavaliação no contexto do Sistema Nacional de Avaliação da Educação Superior?

2. Como o(a) senhor(a) avaliaria a contribuição da academia na política de autoavaliação?

3. Em sua percepção, como a acadêmica percebe a autoavaliação?

Data da realização:

Hora de início:

Hora de término:

Local:

Clima da entrevista:

Aspectos que merecem aprofundamento e/ou utilização de outros instrumentos: 
Apêndice G - Roteiro de entrevista com membro da Comissão Nacional de Avaliação da Educação Superior - Conaes

\section{IDENTIFICAÇÃO:}

Nome do membro da Conaes:

Vinculo Institucional:

Período em que atua como membro da Comissão Própria de Avaliação:

Trajetória acadêmica e profissional:

\section{PERGUNTAS:}

\section{BLOCO 1: OS RELATÓRIOS DE AUTOAVALIAÇÃO E O ATENDIMENTO ÀS} DIMENSÕES DA POLÍTICA DO SINAES

1. Quais os procedimentos esperados de uma Comissão Própria de Avaliação na percepção da Conaes?

2. A partir da sua experiência como membro da Conaes, em que medida o(a) senhor(a) considera que os relatórios de avaliação produzidos atendem as dimensões do Sistema Nacional de Avaliação da Educação Superior?

3. Em sua avaliação, as Comissões Próprias de Avaliação enfrentam dificuldades para coordenar a autoavaliação?

\section{BLOCO 2: O USO DOS RESULTADOS DA AUTOAVALIAÇÃO PELA GESTÃO DAS UNIVERSIDADES}

1. Qual a maneira que a equipe de gestão de uma instituição de educação superior deve acompanhar o ciclo avaliativo da autoavaliação?

2. Em sua avaliação, como membro da Conaes, para que vem servindo, em termos políticos, o relatório de autoavaliação?

3. $\mathrm{O}(\mathrm{A})$ senhor(a) saberia informar experiências nacionais exitosas relacionadas ao uso dos resultados da autoavaliação?

\section{BLOCO 3: O SIGNIFICADO ATRIBUÍDO À AUTOAVALIAÇÃO}

1. Qual a sua análise acerca do papel da autoavaliação dentro do contexto do Sistema Nacional de Avaliação da Educação Superior?

2. Como o(a) senhor(a) avaliaria a contribuição do trabalho da Conaes na política de autoavaliação?

3. Em sua percepção, como a Conaes percebe a autoavaliação?

Data da realização:

Hora de início:

Hora de término:

Local:

Clima da entrevista:

Aspectos que merecem aprofundamento e/ou utilização de outros instrumentos: 
Apêndice H - Roteiro de entrevista com funcionário da Diretoria de Avaliação da Educação Superior (Daes) do Instituto Nacional de Estudos e Pesquisas Educacionais Anísio Teixeira - Inep

\section{IDENTIFICAÇÃO:}

Nome do funcionário da Daes/Inep:

Vinculo Institucional:

Período em que atua como membro da Comissão Própria de Avaliação:

Trajetória acadêmica e profissional:

\section{PERGUNTAS:}

\section{BLOCO 1: OS RELATÓRIOS DE AUTOAVALIAÇÃO E O ATENDIMENTO ÀS DIMENSÕES DA POLÍTICA DO SINAES}

4. Quais os procedimentos esperados de uma Comissão Própria de Avaliação na percepção do Inep?

5. A partir da sua experiência como funcionário(a) da Daes/Inep, em que medida o(a) senhor(a) considera que os relatórios de avaliação produzidos atendem as dimensões do Sistema Nacional de Avaliação da Educação Superior?

6. Em sua avaliação, as Comissões Próprias de Avaliação enfrentam dificuldades para coordenar a autoavaliação?

\section{BLOCO 2: O USO DOS RESULTADOS DA AUTOAVALIAÇÃO PELA GESTÃo DAS UNIVERSIDADES}

4. Qual a maneira que a equipe de gestão de uma instituição de educação superior deve acompanhar o ciclo avaliativo da autoavaliação?

5. Em sua avaliação, como funcionário(a) da Daes/Inep, para que vem servindo, em termos políticos, o relatório de autoavaliação?

6. $\mathrm{O}(\mathrm{A})$ senhor(a) saberia informar experiências nacionais exitosas relacionadas ao uso dos resultados da autoavaliação?

\section{BLOCO 3: O SIGNIFICADO ATRIBUÍDO À AUTOAVALIAÇÃO}

4. Qual a sua análise acerca do papel da autoavaliação dentro do contexto do Sistema Nacional de Avaliação da Educação Superior?

5. Como o(a) senhor(a) avaliaria a contribuição do trabalho do Inep na política de autoavaliação?

6. Em sua percepção, como o Inep percebe a autoavaliação?

Data da realização:

Hora de início:

Hora de término:

Local:

Clima da entrevista:

Aspectos que merecem aprofundamento e/ou utilização de outros instrumentos: 